INVESTIGATION INTO SETTLEMENT BEHAVIOUR OF MUSSELS AND THE HYDROLOGY OF A SELECTED AREA WITH A VIEW TO FARMING THE SHELLFISH

PHILIP TORTELL

Submitted for the degree of Doctor of Philosophy in Zoology at Victoria University of Wellington.

October, 1976 
Physical observations in the Beatrix Basin, Marlborough Sounds, New Zealand, revealed four distinct regions : a partially exposed northern region with moderate water currents, low rainfall, small catchment area and scant freshwater inflow; a central highly exposed region with strong currents, moderate rainfall, no land catchment area and no direct freshwater inflow; an eastern region with a high degree of exposure and strong water movement, moderate rainfall, extensive catchment and seasonally high freshwater inflow; a southern sheltered region with sluggish water movement, comparatively high rainfall, extensive catchment and the highest rainfall in the study area.

Differences between the four regions in monthly mean temperature and salinity were slight and there was an indication of more mixing in the central region than elsewhere. No thermocline was observed and surface water temperature demonstrated a diurnal rhythm in summer. Mean winter temperature fell to $10^{\circ} \mathrm{C}$ and rose to $17^{\circ} \mathrm{C}$ in summer. Mean salinity ranged from $32.8^{\circ} / 00$ in winter to $34.8^{\circ} / 00$ in summer and no halocline was present. Salinity fell occasionally after heavy rain, but tidal currents soon dissipated the freshwater except 
in the southern region where it persisted for a short time.

The reproductive cycles of Perna canaliculus and Mytilus edulis aoteanus, the occurrence of their larvae in plankton samples, their season of settlement and peaks in settlement activity, were monitored. Physical environmental conditions preceeding or accompanying spatfall were recorded. A broad temporal relationship was found between spawning adult mussels, pelagic larvae, environmental conditions, and settlement of perna canaliculus in Elie Bay. It appears that $\underline{P}$. canaliculus spawned in early summer and in autumn when the water temperature was $18 \pm 0.5^{\circ} \mathrm{C}$. However, it was not possible to predict spatfall since the duration of the pelagic phase was not known and settlement is a function of larval survival and dispersal, as well as the presence of a suitable substrate.

Accurate spatfall prediction is required to facilitate timed immersion of spat-collecting ropes while ensuring "seasoning" and avoiding fouling. As it was not possible to predict settlement by relating it to other biological or physical phenomena, this study sought an alternative spat-collecting material not so susceptible to fouling but still attractive to mussels. Carbon black fibrillated polypropylene film proved to be such an alternative. 
The determination of available food for mussels within the study area was attempted using particulate organic nitrogen as the indicator. The problems ercountered are discussed. The concentration of particulate

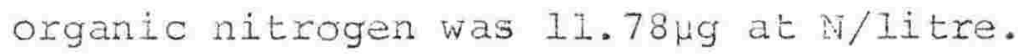

The larvae of Mytilus edulis aoteanus and Aulacomya maoriana were reared in the laboratory to the late veliger stage. The most likely causes of their failure to metamorphose were a too high larval density, an excess of food organisms and the lack of a suitable substrate for settlement. It was not possible to induce spawning of Perna canaliculus under controlled conditions. 
SECTION ONE

General Introduction

Literature Cited

SECTION TWO

Physical Observations in the Beatrix Basin, Marlborough Sounds

2.1 Physiography

Geological History
Topography
Freshwater Inflow
Bathymetry

2.2 climate

Methods

Results

2.3 Hydrology

Methods

Results

2.4 Discussion

The Northern Region

The Eastern Region

The Southern Region

The Central Region 
SECTION THREE

The Reproductive Cycle of Mussels and Their Settlement and Survival on Materials with Commercial potential

3.1 Introduction

3.2 Materials and Methods 59

3.2.1 Spatfall Forecasting 59

3.2.2 Settlement and Settlement Materials 63

3.3 Results and Discussion 71

3.3.1 Reproductive Cycle 73

3.3.2 Planktonic Larvae 86

3.3.3 Settlement 95

A) Season and Survival 95

B) Depth Preference 105

3.3.4 Analysis of Experimental Materials 112

A) Preliminary Experiments $\quad 112$

B)Successful Collectors 114

$\begin{array}{ll}\text { C) Fouling and Competitors } & 127\end{array}$

3.4 Conclusions 130

Acknow ledgments $\quad 133$

$\begin{array}{lll}3.5 & \text { Literature Cited } & 134\end{array}$

SECTION FOUR

Prospects for Mussel Farming in the Beatrix Basin, Marlborough Sounds 156

$\begin{array}{ll}\text { General Acknow ledgments } & 167\end{array}$

$\begin{array}{ll}\text { Literature Cited } & 169\end{array}$ 
APPENDIX A

Difficulties in the Determination of the Available Food for Mussels

5.1 Mussel Food

5.2 Methods of Assessment 174

5.3 Collecting the Sample 175

5.4 Chemical Analysis 177

5.5 The Present Study 178

Acknowledgments $\quad 182$

5.6 Literature Cited 183

APPENDIX B

Experimental Rearing of Mussel Larvae in the Laboratory

6.I Introduction 190

6.2 Methods 190

The Physical Plant 190

Conditioning 196

Spawning Induction $\quad 196$

Culture Techiniques 198

6.3 Results 198

Mytilus edulis aoteanus $\quad 198$

Aulacomya maoriana 201

Perna canaliculus 203

6.4 Discussion 205

Acknowledgments 208

6.5 Literature Cited 209 
Figure 1.1 Marlborough Sounds

page

1.2 Beatrix Basin, Marlborough Sounds 6

2.1 Marlborough Sounds Geology 14

2.2 Beatrix Basin - Physical Features 16

2.3 Beatrix Basin - Topography 17

2.4 Beatrix Basin - Freshwater Inflow 19

2.5 Beatrix Basin - Bathymetry 20

2.6 Beatrix Basin - Selected Bottom
Profiles

2.7 Elie Bay - Weather $1.973 \quad 27$

2.8 Diurnal Wind Rhythm 28

2.9 Elie Bay - Wind Roses 28a

2.10 Wind Strength according to Direction $28 \mathrm{~b}$

2.11 Marlborough Sounds - Rainfall
Distribution 1973

2. 12 Beatrix Basin - Hydrological Stations 32

2.13 Beatrix Basin - Temperature 36

2.14 Beatrix Basin - Salinity 36a

2.15 Waimaru Raft - Temperatures 39

2.16 Drift Card Recoveries and Possible
Paths

2.17 Drift Card Recoveries and Possible
Paths

2.18 Drift Card Recoveries and Possible Paths 
2.19 Movement of Dye patches

3. I Beatrix Basin - Biological Stations 61

3.2 Biological and Physical Records 72

3.3 Reproductive Cycle of Perna canaliculus 82

3.4 Reproductive Cycle of Mytilus edulis aoteanus

3.5 Planktonic Larvae 90

3.6 Daily Mean Settlement 97

3.7 Size-class Distribution on Eong Term
Collectors

3. 8 Size-class Distribution by Depth 108

4.1 Potential Mussel Farming Areas in the
Beatrix Basin

6.1 Diagram of Larval Rearing Unit 191

LIST OF PLATES

Plate 2.1 Elie Bay Panoramic View 23

2.2 Elie Bay Climatological station 23

2.3 Fluorescene Dye Patches 34

3.1 Six Materials Tested for Mussel
Farming

3.2 Three Successful Mussel Collectors 64

3.3 Metal Frame Used to Suspend Collectors 64

3.4 Rubberised Hair Packing - 'Hairlok' 68

3.5 Perna canaliculus - Male Reproductive 75

$3.6 \frac{\text { Perna canaliculus - Female Reproductive }}{76}$

3.7 $\frac{\text { Mytilus edulis aoteanus }}{\text { Reproductive Cycle }} \quad 77$ 
3.8 $\frac{\text { Mytilus edulis aoteanus }}{\text { Reproductive Cycle }}$ Female

3.9 Planktonic Bivalve Larvae 87

3.10 Perna canaliculus on hydroid 'stems' 123

3.11 S.E.M. of Successful Mussel Collecting Materials

3.12 Black Polypropylene Film 126

4.1 Commercial Mussel Rafts 158

4.2 Polyethylene Buoys as used in Long Lines 160

5.1 Water Sampling for Particulate Organic Nitrogen

5.2 Analysis for Determination of Particulate Organic Nitrogen

6.1 Larval Rearing Unit - Conditioning Rack

6.2 Larval Rearing Unit - Algal Culture Bank

6.3 Larval Rearing Unit - Filtration and Water Sterilizing Equipment; Constant Temperature Baths

6.4 Spawning Induction Dish

6.5 Mytilus edulis aoteanus - Larval Development

6.6 Mytilus edulis aoteanus - Larval Development (continued)

6.7 Aulacomya maoriana - Larval Development

6.8 Perna canaliculus - Larval Development 204 
SECTION ONE

GENERAL INTRODUCTION 
Mussels were first farmed in the thirteenth century by an Irish sailor shipwrecked on the west coast of France (Andreu, 1958). His method, known as the bouchot system, (see Field 1922, Iversen 1968), is still the principal method of mussel cultivation in France. In Folland mussels are cultivated on the seabed (Havinga, 1964) and production has reached 105,900 tonnes annually (Maclean, 1972). The Galician Rias of Spain produce $50 \%$ of total world production (170,000 tonnes) according to Andreu (1973). Here, the method of cultivation is on ropes hanging from rafts. This method and variations of it (Fauvel 1954, Nikolic \& Stojnic 1963, Andreu 1968, Waugh 1968, 1971, Ivanov 1971, 1971a, Maclean 1972, Martinez 1971, Mason 1972, 1972a, Machado \& Mota 1974) is now the most widely practised.

The demand for mussels in New Zealand has in recent years exceeded the supply which was made up entirely of dredged Perna canaliculus, although the cosmopolitan Mytilus edulis (subspecies aoteanus) is present in New Zealand waters. Despite a rising tendency in the landings of dredged mussels in 1958, it had already been noticed that mussel beds were not being replenished (Reid, 1969). Commercial landings reached a maximum in 1961 and then declined rapidly until in 1967 when no regular landings were made (Greenway, 1969). The first experimental raft was launched in 1965 at Ponui Island, Hauraki Gulf 
(MacFarlane, 1971) and this was followed by another experimental raft at Te Kouma Harbour, Coromandel (Greenway, 1969a). In 1969 commercial-sized pontoons were launched in the Hauraki Gulf (MacFarlane op. cit.) and the Marlborough Sounds (Guard, 1971). In the latter area, mussel beds had been depleted by over-dredging in the same manner as in the Hauraki Gulf (Stead, 1972).

Long term research was initiated by Victoria University in conjunction with Fisheries Research Division, Marine Department, in mid-1968 in the Marlborough Sounds (Flaws, 1971). The Fishing Industry Board hosted a seminar on mussel cultivation in 1971, where the state of the industry and its future potential were assessed. The prediction of spatfall (Guard 1971, MacFarlane 1971, Waugh 1971a), and the hydrology of prospective mussel farming areas (Greenway 1971, Waugh op. cit.) were among the topics thought to require further research. This study was initially planned with these two topics in mind.

The Beatrix Bay/Clova Bay/Crail Bay complex in the Marlborough Sounds (Figure 1.1) was selected as the study area for a number of reasons. The area encompasses a collection of bays which seemed different enough hydrologically to permit comparative analysis; it was at the same time a large self-contained area of water which could also be treated as a whole. It was not on any of the more popular navigation routes, away from the main 


\section{MARLBOROUGH SOUNDS}

(By permission of the Department of the Navy) 


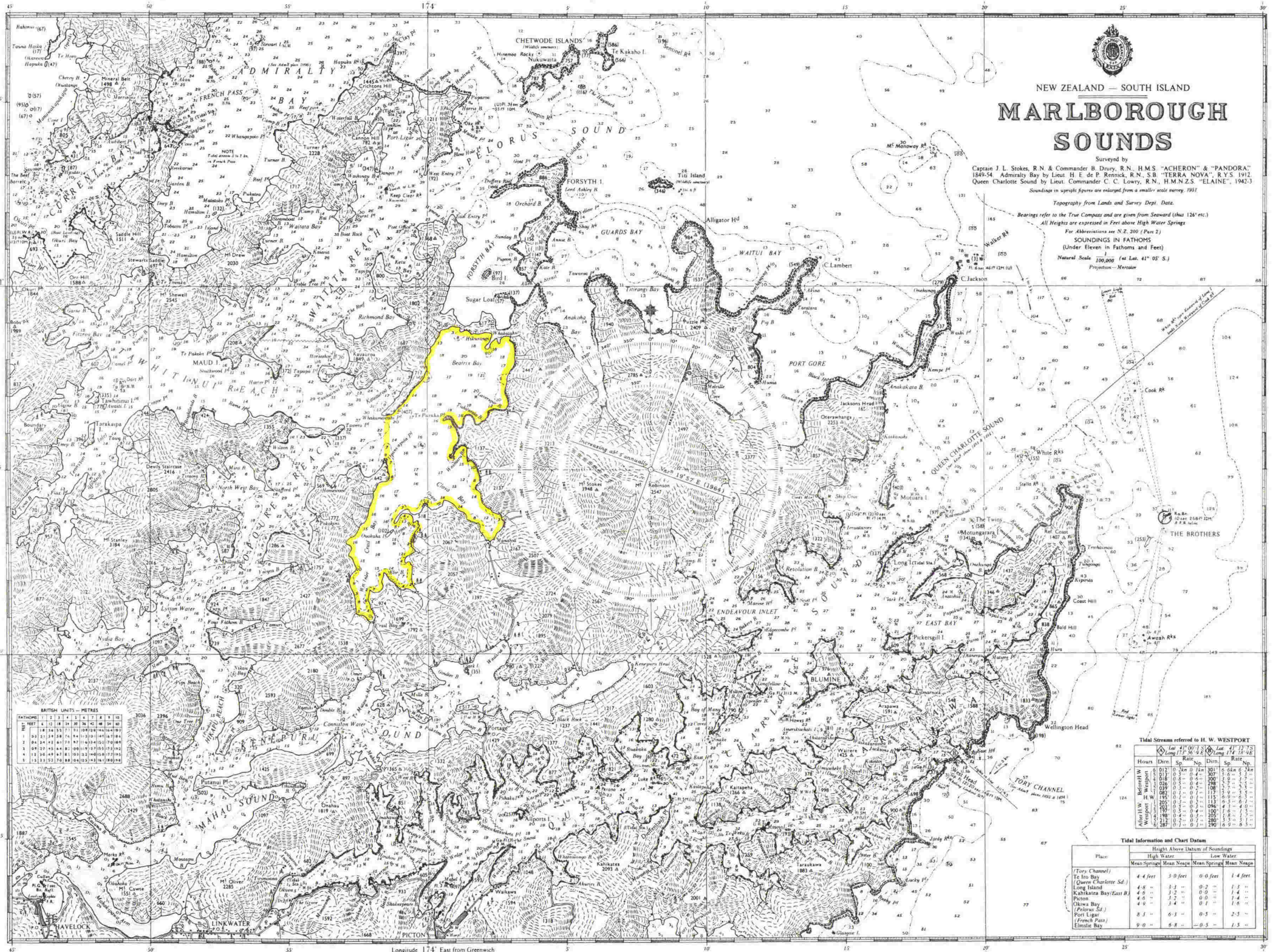


FIGURE 1.1

MARLBOROUGH SOUNDS

(Study area coloured) 
recreational area and free from any pollution. If any substantial area could be set aside for mussel farming within the Marlborough Sounds, this area appeared to be the most likely choice. It was decided to call the entice region the Beatrix Basin (Eigure 1.2) since Beatrix Bay is the largest component.

A detailed overall picture of any area being considered for intensive mussel farming is of undisputed value. Climatological, hydrological, biological as well as sociological information is essential before a reliable assessment of the potential of an area can be attempted. Studies along these lines were initiated during the present research programme within the limits of available time and resources.

Observations on the physiography, climate and hydrology of the study area are presented in Section Two. Section Three deals with aspects of reproduction and settlement behaviour of mussels with observations on the more important competing organisms. This section also deals with the discovery of a new rope for mussel farming. The potential of the Beatrix Basin for intensive mussel. farming is discussed in section Four in the light of the present findings. Appendix $A$ is a review of methods which have been used in determining the availability of food for mussels and the difficulties encountered with the method adopted. An attempt to rear mussel larvae in the 
BEATRIX BASIN, MARLBOROUGH SOUNDS

The study area was called the Beatrix Basin after Beatrix Bay which comprises the largest stretch of water. 


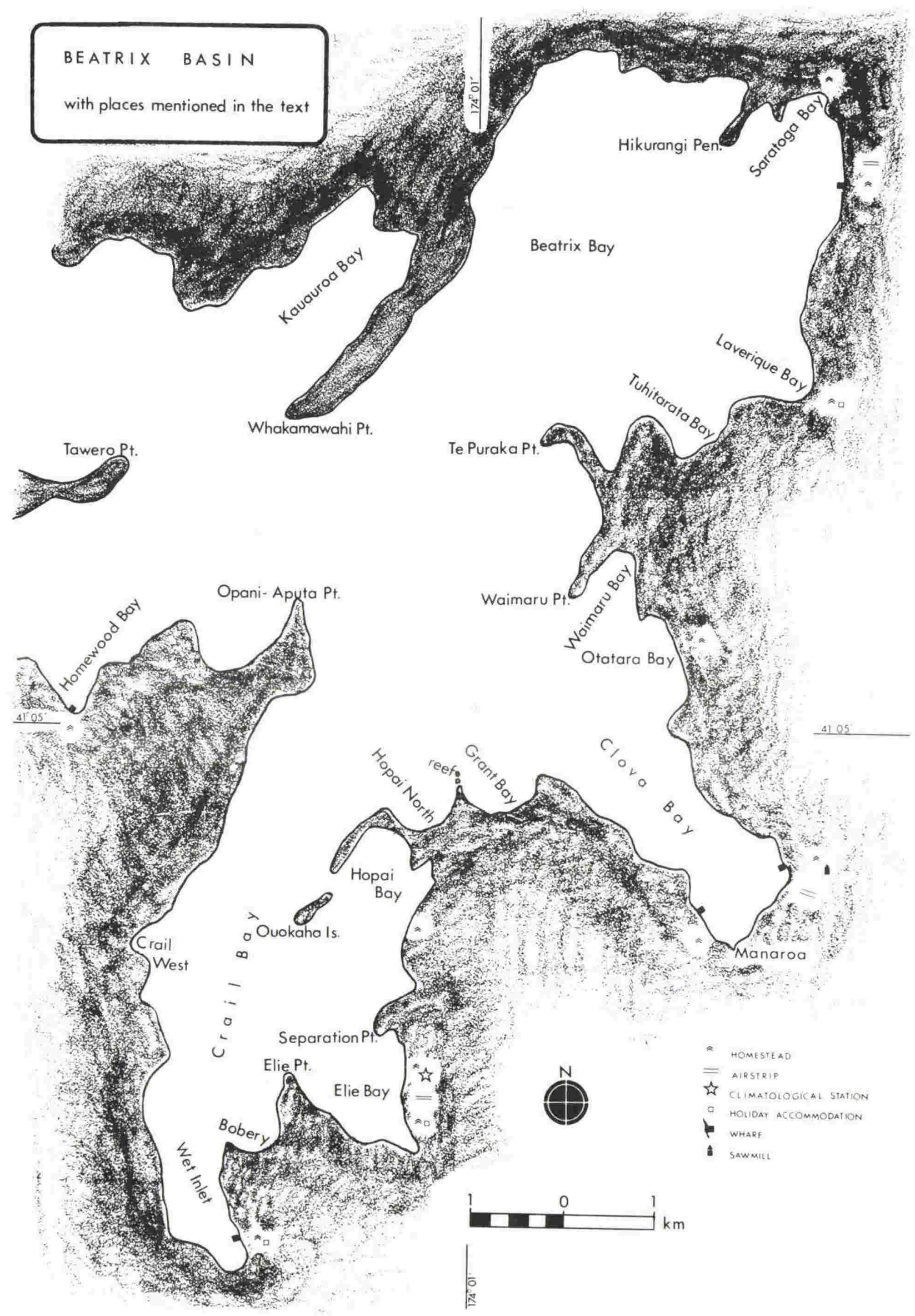


laboratory was not entirely successful, however, the results obtained and possible reasons for failure, are presented in Appendix B.

Four progress reports were produced during the course of the study and widely circulated both within New Zealand and overseas. The aim of these reports was to make information available as it came to hand. Preliminary results were discussed on three occasions at mussel workshops organised by the Fishing Industry Board. Three papers on aspects of the research programme were presented at conferences of the New Zealand Marine Sciences Society. The mussel research programme was also the topic of seminars delivered at the Rosensteil School of Marine and Atmospheric Science, Miami, Florida, and the Food Technology Department of the East-West Center, Honolulu, Hawaii. The present study has resulted in three publications to date (Tortell 1972, 1976a, 1976b) 
ANDREU, B. (1958) Sobre el cultivo del mejillon in Calicia - biologia, crecimiento y produccion. Investigaciones pesqueras $745 / 746: 44-47$

ANDREU, B. (1958) The importance and possibilities of mussel culture. Seminar on Possibilities and Problems in Eisheries Development in Southeast Asia - German Foundation for Developing Countries, Working Paper 5 : 15pp

ANDREU, B. (1973) Perspectivas de la acuicultura marina en Espana. Informes Tecnicos del Instituto de Investigaciones Pesqueras $9: 47 p p$

FAUVEL, Y. (1954) Methodes d'elevage des moules et huitres dans I'etang de Thau. General Fisheries Council for the Mediterranean Proceedings \& Technical paper no. $22: 251-255$

FIELD, A.I. (1922) Biology and economic value of the sea mussel, Mytilus edulis. Bulletin U.S. Bureau of Fisheries 38: 127-259

FLAWS, D.E. (1971) Observations on mussel biology, Cook Strait area. Report on Mussel Cultivation Seminar. October 1971, Fishing Industry Board, : $14-20$ 
GRPENWAY, J.P.C. (1969) Surveys of mussels (Mollusca: Iamellibranchia) in the Firth of Thames, 196167. New Zealand Journal Marine \& Freshwater $\underline{\text { Research } 3(2): 304-317}$

GREENWAY, J.P.C. (1969a) Settlement and growth of a colony of the large green mussel from a pontoon in Te Kouma Harbour, Coromandel. New Zealand Marine Department, Fisheries Technical Reports no. $43: 14 \mathrm{pp}$

GREENWAY, J.P.C. (1971) Some observations on mussels in the Hauraki Gulf. Report on Mussel Cultivation Seminar, October 1971, Fishing Industry Board, : $7-9$

GUARD, C. (1971) Mussel farming project in the Marlborough Sounds. Report on Mussel Cultivation Seminar, October 1971, Fishing Industry Board : 21-23

HAVINGA, B. (1964) Mussel culture. Sea Frontiers 10(3): $155-166$

IVANOV, A.J. (1971) The first successful experiment in the cultivation of mussels in the U.S.S.R. Rybnoe Khozyaistvo 9: 18-19 (in Russian)

IVANOV, A.J. (1971a) Preliminary results of cultural rearing of mussels (Mytilus galloprovincialis Lam) in the Bay of Kerch and in some Black sea areas. Okeanologia $11(5): 889-899$ (in Russian) 
IVERSEN, E.S. (1968) Farraing the Edge of the Sea Fishing News Books, London, $303 \mathrm{pp}$

MACFARIANE, S. (1971) New zealand commercial mussel farming experiments in the Hauraki Gulf. Report on Mussel Cultivation Seminar, October 1971, Fishing Industry Board : 10-12

MACLEAN, J.L. (1972) Mussel culture: methods and prospects. Australian Fisheries Paper no. 20 $13 \mathrm{pp}$

MARTINEZ, R.E. (1971) Estado actual de la biologia Y cultivos de moluscos comestibles in Venezuela. F.A.O. Fisheries Report $71(20): 173-181$

MASON, J. (1972) The cultivation of the European mussel Mytilus edulis Linnaeus. Oceanography Marine Biology Annual Reviews 10: 437-460

MASON, J. (1972a) Mollusc culture in Scotland. World Fishing, September 1972: 42-44

MILNE, P.R. (1970) Marine fish farming in scotland. World Fishing. September 1970: 46-50

MOTA, A.M.C. \& MACHADO, J.F.S. (1974) Cultura experimental de mexilhao Perna perna I. em Angola. Pubblicazioni Mimeograf del Missao de Estudos Bioceanologicos e de Pescas de Angola, 13(4): 30pp 
NIKOLIC, M. \& STOJNIC, I. (1963) A system of mussel

culture. General Fisheries Council for the

Mediterranean, Technical Paper No. 22 : 251-255

REID, B. (1969) Mussel survey Hauraki Gulf and Firth of

Thanes 1353. New Zealand Marine Department

Fisheries Technical Report no. $34: 24 \mathrm{pp}$

STEAD, D.H. (1972) Pelorus Sound Mussel Survey, December

1969. New Zealand Marine Department Fisheries

Technical Report no, $62: 28 p$ p

TORTELL, P. (1972) Mussel research Programme. Commercial

Fishing $12(11): 18-19,24$

TORTELL, P. (1976a) Particulate organic nitrogen in the

Marlborough Sounds. New Zealand Joumal of

Marine and Freshwater Research (in press)

TORTELL, P. (1976b) A new rope for mussel farming.

Aguaculture (in press)

WAUGH, G.D. (1968) A crop from the sea. Commercial

Fishing $7(2): 30-36$

WAUGH, G.D. (1971) Prospects for mussel cultivation

in New Zealand and observations on the Spanish

mussel cultivation industry. Report on Mussel

Cultivation Seminar, October 1971, Fishing

Industry Board : $1-3$

WAUGH, G.D. (1971a) Future mussel research requirements. Report on mussel Cultivation Seminar, October 1971, Fishing Industry Board : 30 
SECTION TWO

PHYSICAL OBSERVATIONS IN THE BEATRIX BASIN, MARLBOROUGH SOUNDS 


\section{Geological History}

The oldest rocks in the Marlborough Sounds region belong to the Marlborough Schists Group (Stevens, 1974). These were laid down in the original New Zealand geosyncline during the Carboniferous (Grindley, 1961) and metamorphosed by subsequent burial during the Triassic.

Cook Strait was probably formed in the Upper pliocene but the Upper Pleistocene drop in sea level reformed the land bridge across the strait. During the last glaciation the area received large amounts of river gravels and formed part of a moist cool-temperate forest between the alpine regions of the two islands. By this time the land had been tilted in such a way as to reverse the original drainage pattern of the area (Stevens, 1974). The present day Marlborough Sounds are the submerged remnants of this ancient valley system.

The study area lies across one of the many faults in the region with Pelorus Group greywackes and argillites on the downthrown western side and Marlborough Schists of the Pelorus Regional Anticline on the uplifted eastern side (Figure 2.1). The schists are of the Chlorite SubZone II and the result of high stress low temperature activity. They grade into the greywackes which are of the undifferentiated type and which contain a prominent 
MARLBOROUGH SOUNDS GEOLOGY

A simplified geological map of the Marlborough Sounds adapted from Beck (1964). The study area (in yellow) is bissected by at least one fault line which is shown clearly in the crosssection A - B. 
FIGURE 2.1

MARLBOROUGH SOUNDS

\section{GEOLOGY}

(From: Beck, 1964)
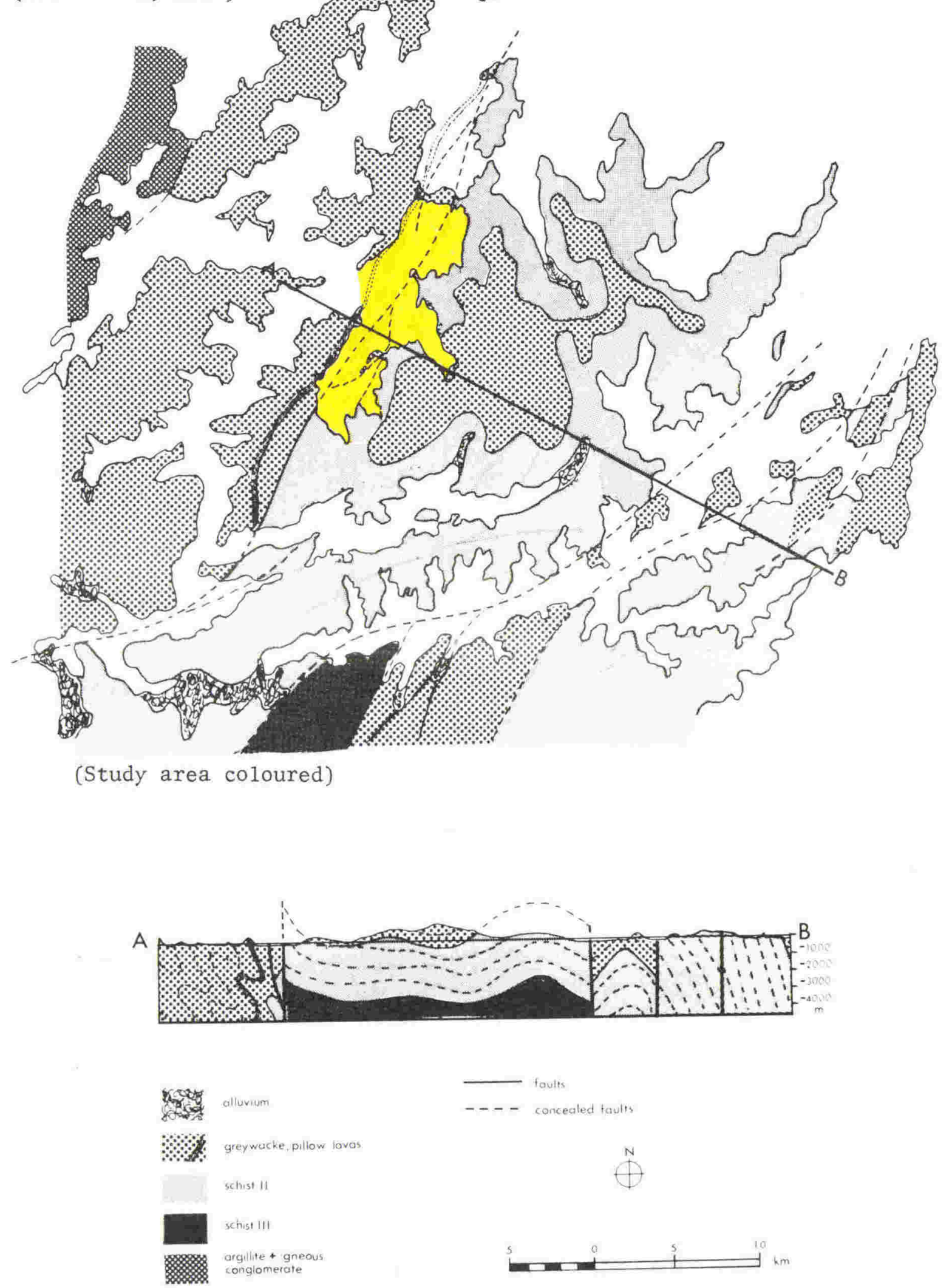
band of red volcanic conglomerate exposed on the western shores of Crail Bay and again, partially, in Beatrix Bay (Beck, 1964).

\section{Topograohy}

The Beatrix Basin (see Figure 2.3) is characterised by steep hills (mean altitude $650 \mathrm{~m}$ ) often rising straight from the water's edge. All comparatively level ground occurs on the eastern and southeastern aspects. The whole area is dominated by the mass of Mt Stokes $(1200 \mathrm{~m})$ and Mt Kiwi (975m) which are situated centrally on the eastern side. At the northern end the Basin is separated from Forsythe Bay and cook strait by a narrow isthmus of land $3 \mathrm{~km}$ long and $180 \mathrm{~m}$ at its highest point. The entrance to the area, which is $2.2 \mathrm{~km}$ wide, is situated centrally on the western side. The local topography results in exposure from the northerly and northwesterly aspects.

The great majority of the catchment area, which totals $92.7 \mathrm{~km}^{2}$, is covered in either bush or scrub (see Figure 2.2). Pasture forms a very small percentage of the total area and is restricted to the scarce level ground round Wet Inlet, Elie Bay, Manaroa and Beatrix Bay. Extensive reafforestation with exotic pines is planned for most of the area.

The longest axis of the Basin is $15.6 \mathrm{~km}$ while the total water surface area is $50.75 \mathrm{~km}^{2}$. The region can be divided 


\section{BEATRIX BASIN}

The main physical features of the study area are shown as well as predominant land use as at 1974. Extensive areas of bush and scrub will be shortly planted in exotic pine forest. 
FIGURE 2.2

BEATRIX BASIN

SURFACE AREA $50.75 \mathrm{~km}^{2}$

CATCHMENT AREA $92.70 \mathrm{~km}^{2}$

WATER VOlume $1430.5 \times 10^{6} \mathrm{~m}^{3}$
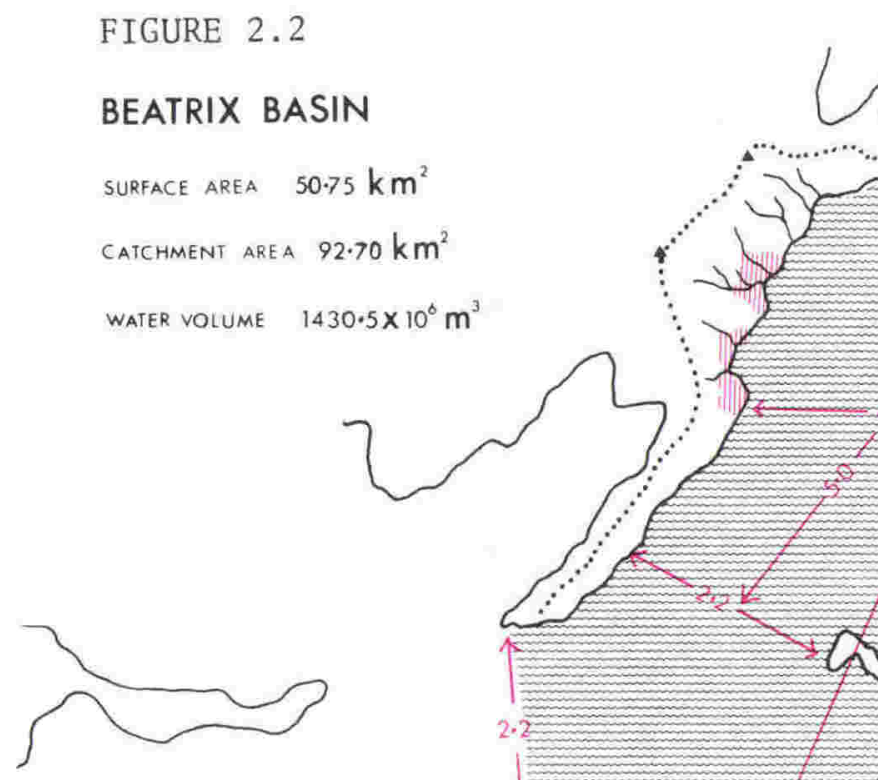

几

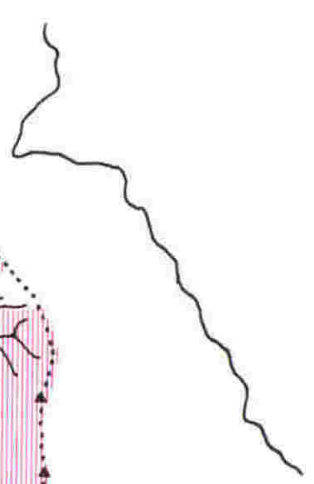

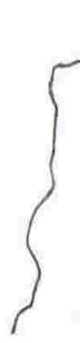

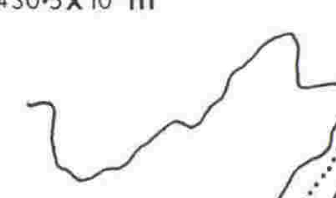


BEATRIX BASIN

Photographic mosaic of the study area showing the division into regions adopted for hydrological studies.

(By permission of Lands \& Survey Department) 


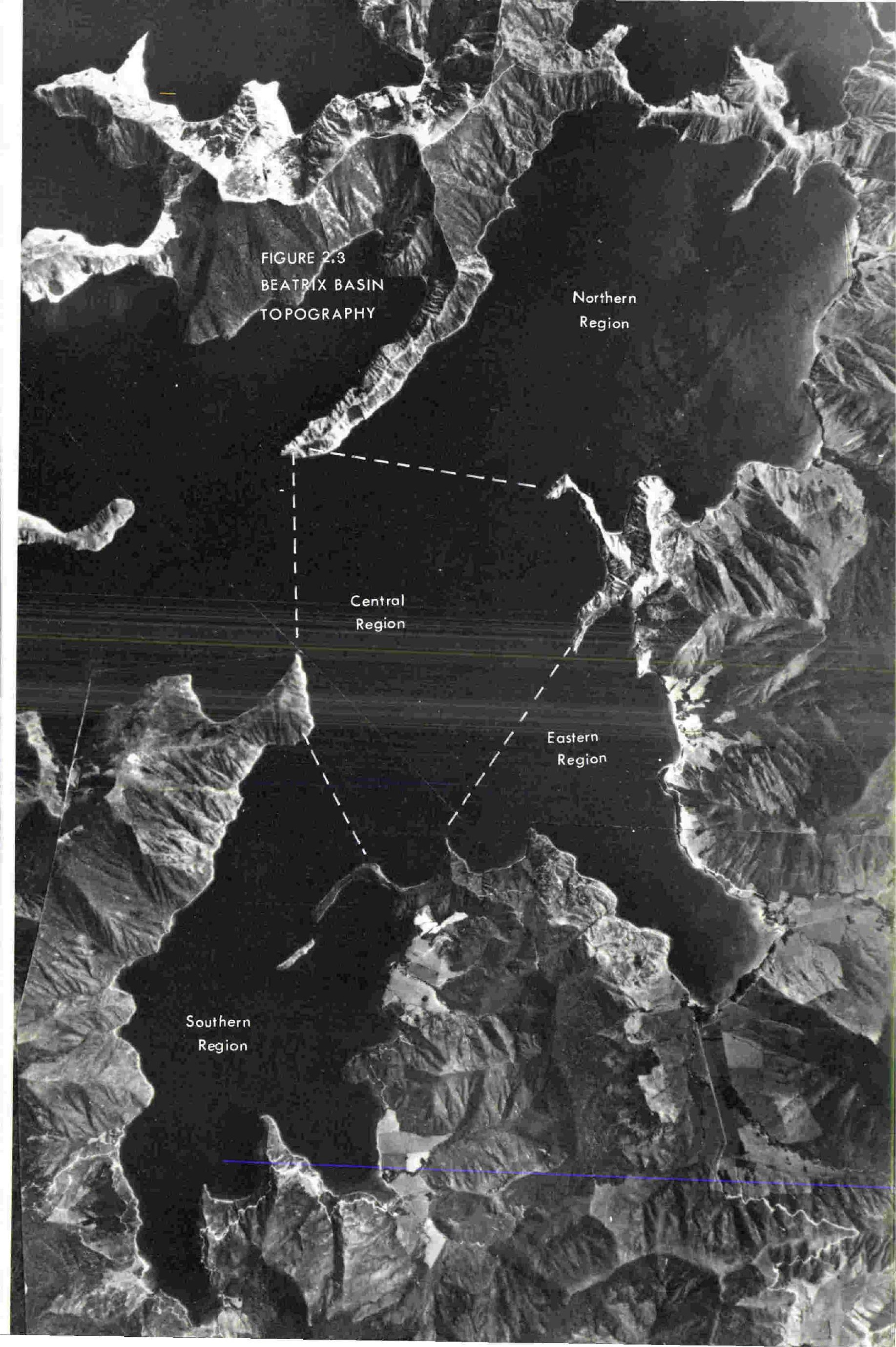


into four broad areas namely, Beatrix Bay to the north, Clova Bay at the east centre, Crail Bay to the south, and a central area (see Figure 2.3).

\section{Freshwater InElow (Figure 2.4)}

Some of the streams in the Basin were monitored at the end of summer 1974 using a Gurley Pigmy type flowmeter. Drought conditions had prevailed for some time prior to the measurements and therefore the data is possibly an underestimation. The Manaroa River, which is normally the largest in the area, was completely dry. Many other streams were too low for flowmeter recordings. The highest flow recorded was on one of the secondary streams in wet Inlet. This short stream was carrying nearly $0.5 \mathrm{~m}^{3} / \mathrm{s}$. This, and most other streams still flowing at the time, are known to be spring-fed.

\section{Bathymetry}

The bathymetry of the Beatrix Basin was determined using the Simrad Skipper echosounder on board the R V Tirohia. The resulting chart is shown in Figure 2.5. The seabed is basically flat and approximately $30 \mathrm{~m}$ in depth over the majority of the Basin except for a slight rise into Clova and Crail Bays. There is a sill at the entrance with a steep drop to nearly $60 \mathrm{~m}$ on the outside. An interesting feature is a pinnacle which occurs in the centre of the Basin and which rises from $30 \mathrm{~m}$ to $9 \mathrm{~m}$ below the surface. It is possible that this is an outcrop of the red volcanic 
BEATRIX BASIN FRESHWATER INFLON

Streams were monitored in late summer 1974 after an extremely dry period. 


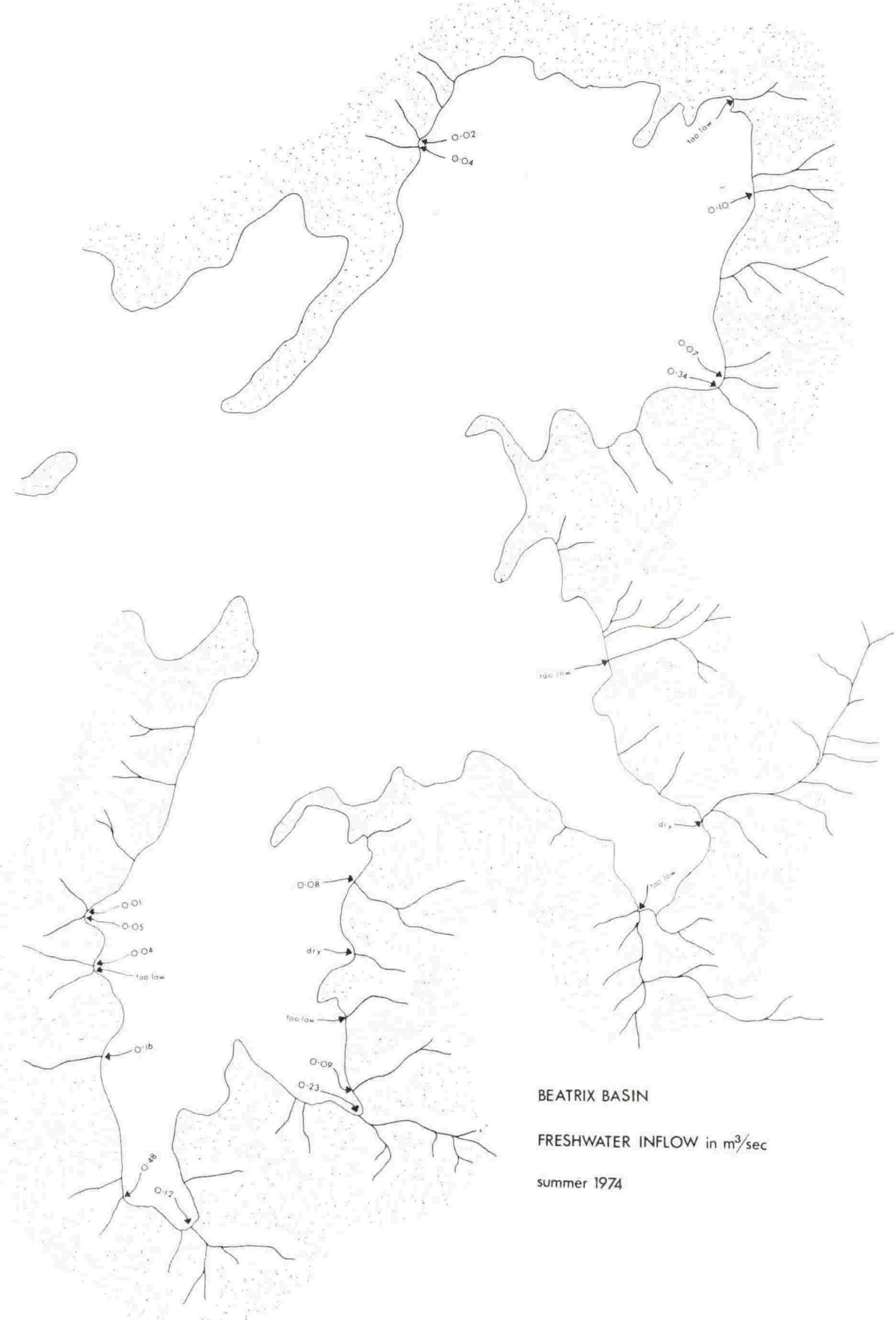


FIGURE 2.5

BEATRIX BASIN BATHYMETRY

Survey carried out by echosounding on $r \mathrm{~V}$ Tirohia.

FIGURE 2.6

BEATRIX BASIN - SELECTED BOTTOM PROFILES

Echosounder traces revealed scour trenches off most headlands in Beatrix Basin. These indicate currents strong enough to prevent mud from settling in these areas. 


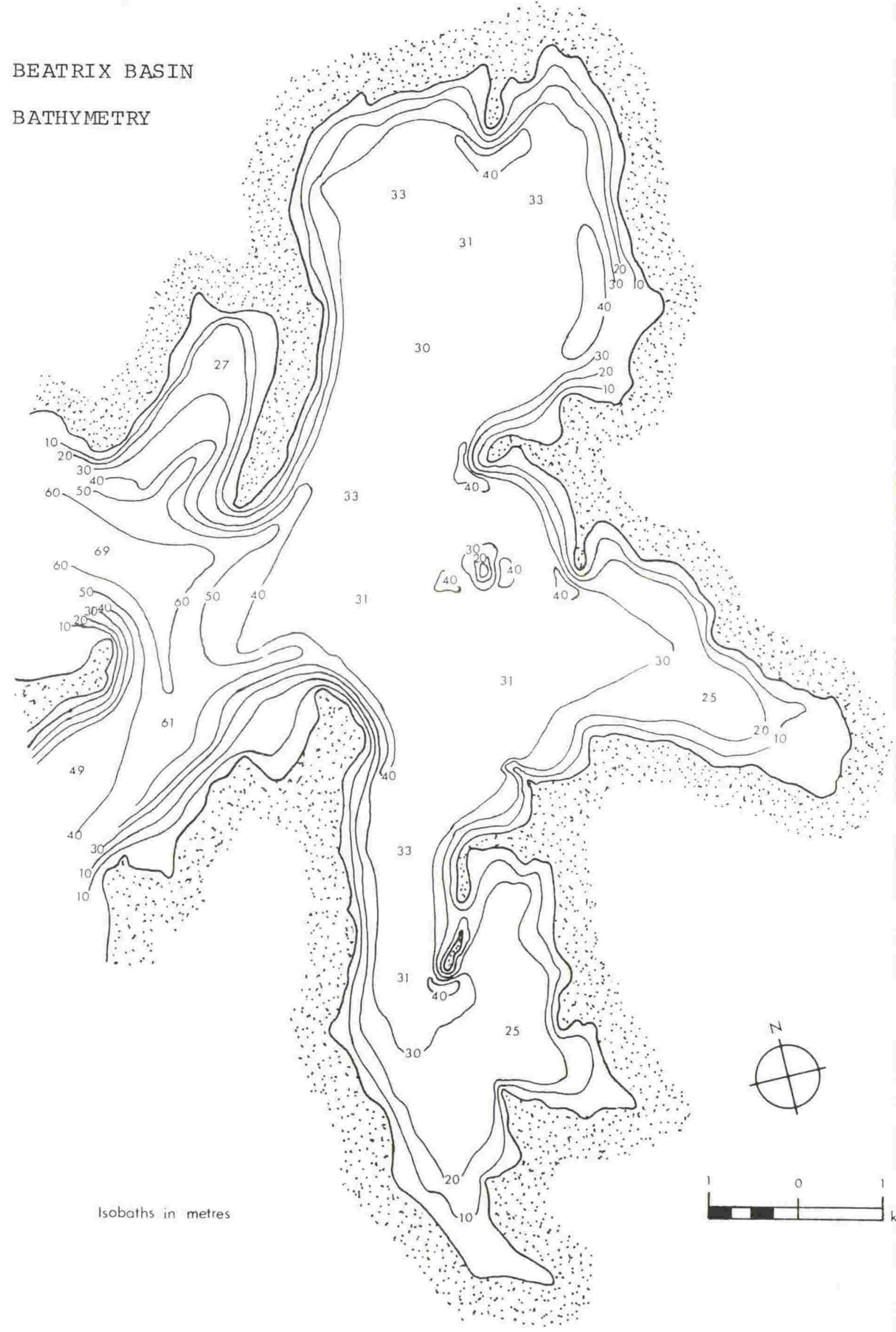




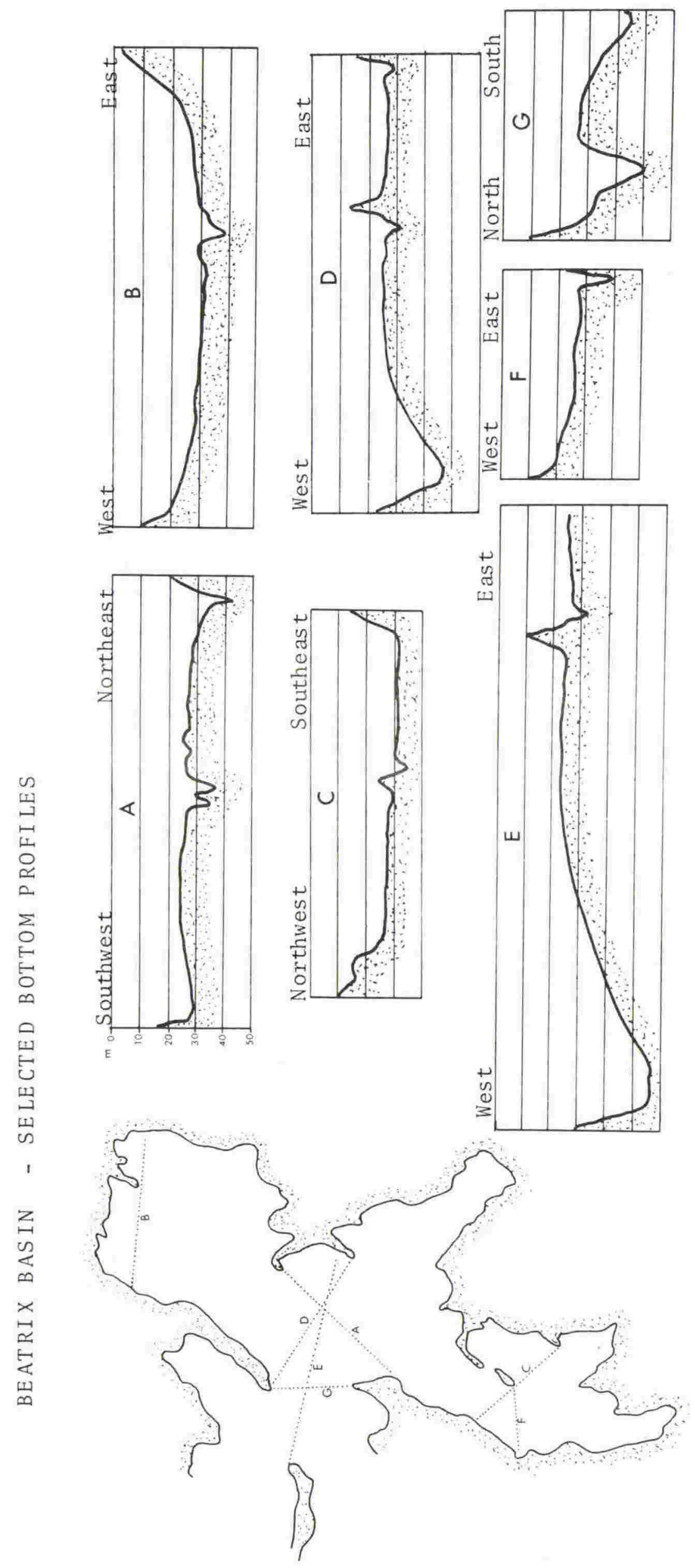


argillite and conglomerate band.

There are two depressions on either side of the pinnacle possibly caused by turbulence due to tidal currents. scouring of the bottom is comon off most of the headlands in the Basin as well as south of Ouokaha Island (Figure 2.6). As all these scourings are about $10 \mathrm{~m}$ deeper than the surrounding bottom it is possible that this represents the thickness of the mud layer which is prevented from forming where currents of certain magnitudes occur. Mean depths and estimated volumes of water for each of the four regions appear in Table 2.4. The maximum tidal amplitude recorded over a period of four weeks in August 1973 at Beatrix Bay wharf was 2.3m while the minimum was 1.2m. Maxima of up to $4 \mathrm{~m}$ are reported to occur at extreme spring tides. If $2 \mathrm{~m}$ is taken as the mean amplitude (Heath, 1974) the tidal compartments would be as in Table 2.4.
2.2
CLIMATE

\section{Methods}

Brightlands Bay climatological station $\left(41^{\circ} 04^{\prime} \mathrm{S}, 173^{\circ}\right.$ $51^{\prime}$ E) is situated ca $12 \mathrm{~km}$ to the west of Beatrix Basin and apart from a number of rainfall stations, was the only one in the Marlborough Sounds. The Elie Bay station was set up in september 1972 with the aim of providing further information on the sounds climate in general and 
the study area in particular. Due to the size of the study area and its physiography there are limitations in applying the results from Elie Bay to the rest of the Basin.

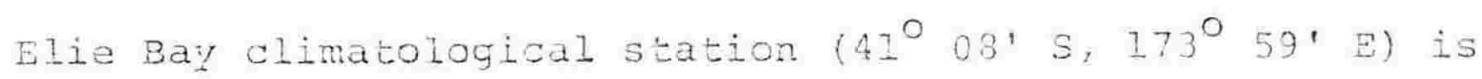
situated about $50 \mathrm{~m}$ from the shore at an altitude of $9 \mathrm{~m}$ and is surrounded by hills except from the westerly quarter (see Plates 2.1 and 2.2 ). Recordings were made at 0800 NZST and included:-
a) cloud amount in eighths
b) visibility in kilometres
c) surface wind direction and speed (Beaufort scale)
d) rainfall over previous 24 hours
e) maximum temperature over previous 24 hours
f) minimum temperature over previous 24 hours
g) sea condition (also recorded at 1200 hours)
h) wet and dry bulb thermometer readings
i) other phenomena like snow, hail, thunder, etc.

Items a), b) and i) were not relevant to the present study while c) was discarded in favour of recordings from a Lambrecht Anemograph which was installed on a standard mast at a height of $6 \mathrm{~m}$ (see Plate 2.2). The instrument recorded wind direction by a wind vane against time of day. Wind run in metres was also recorded and mean wind speeds evaluated from this. The anemograph does not record wind gusts. Data for the period February 1973 to February 1974 was processed by the New Zealand Meteorological Service 
PLATE 2.1

ELIE BAY PANORAMIC VIEW

Elie Bay is viewed from Elie pt and lies to the right of the picture. On the left is Hopai Bay with Separation Pt between the two bays. The arrow indicates the position of the climatological station.

PLATE 2.2

ELIE BAY CLIMATOLOGICAI STATION

The view from the station looking across Elie Bay towards Elie pt (just out of the picture on the right). The station is virtually surrounded by hills except from the northerly and northwesterly directions. 

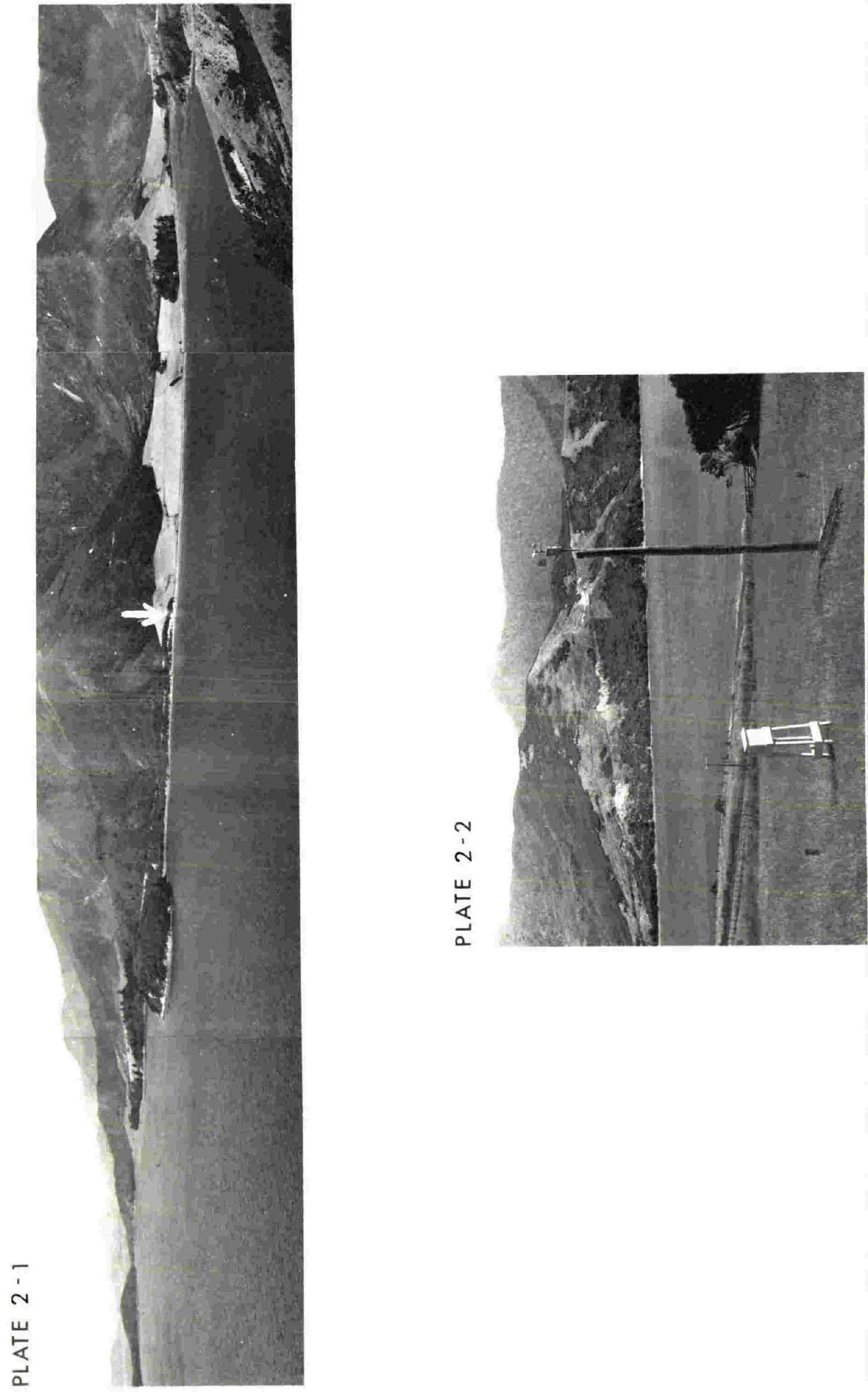
computer using a standard programme.

A standard type rain gauge with a diameter of $12.7 \mathrm{~cm}$ at the collecting rim was mounted over a level grassed surface with the base sunk in the ground and the rim $30 \mathrm{~cm}$ above ground. Readings were taken to the nearest $0.1 \mathrm{~mm}$. Since no direct measurements were available, the rate of evaporation from the water surface in the Beatrix Basin was estimated by the application of a modified Sellers/ Budyko formula (Coulter, New Zealand Meteorological Service, pers. com.) :-

$$
E=0.11 \times u \times\left(e_{S}-e\right)
$$

where:

$$
\begin{aligned}
0.11= & \text { constant } \\
u= & \text { wind speed in } \mathrm{m} / \mathrm{s} \\
e_{\mathrm{S}}= & \text { saturation vapour pressure at the } \\
& \text { temperature of the water surface } \\
\mathrm{e} & =\text { air vapour pressure }
\end{aligned}
$$

Severe limitations are inherent to the formula and its application to the study area. The data thus obtained cannot be taken as more than a mere indication of the true rate of evaporation.

The sea condition was assessed according to the standard scale in Table 2.1. Elie Bay is a very sheltered area 
and this data is therefore limited in its application to the rest of the Beatrix Basin.

\section{TABLE 2.1 STATE OE THE SEA}

$\begin{array}{lll}\begin{array}{c}\text { Metres } \\ \text { (wave height) }\end{array} & \text { Description } & \text { Code } \\ 0 & \text { calm (glassy) } & 1 \\ 0.0-0.1 & \text { calm (rippled) } & 2 \\ 0.5-1.25 & \text { slight } & 3 \\ 1.25-2.5 & \text { moderate } & 4 \\ 2.5-4.0 & \text { rough } & 5 \\ 4.0-6.0 & \text { very rough } & 6 \\ 6.0-9.0 & \text { high } & 7 \\ 9.0-14.0 & \text { very high } & 8 \\ \text { 0ver } 14.0 & \text { phenomenal } & 9\end{array}$

\section{Results}

The Beatrix Basin was a windy area according to the records for the study period. The mean speed was 7.3 knots with a maximum hourly mean of 30 knots. There were 875 hours of calm during the twelve months of observation, mostly during the winter months or late summer. The windiest months were 
October and November while June and July were the calmest (Figure 2.7). There was a tendency for the early morning to be a calm period with the wind rising to a peak towards the afternoon. The resultant diurnal pattern is shown in Figure 2.8 .

Winds from the north, south and southeast were the most frequent while westerlies were rare. Monthly records show only slight differences in wind direction (Figure 2.9).

Northerly winds were over 10 knots nearly $50 \%$ of the time and the top speed from this direction was 24 knots. Southerly winds recorded a maximum speed of 28 knots and were over 10 knots for 59\% of the time. Winds from the southeasterly direction recorded 30 knots on two occasions and were over 10 knots for $79 \%$ of the time.

It seems therefore that while westerlies were insignificant, easterly winds were slightly more common but just as light. Northerlies were quite persistent and could be quite fresh, while southerlies and southeasterlies were both very common and strong (Figure 2.10).

Rainfall in 1973 was below normal all over New Zealand, mainly by $20 \%$ (New Zealand Meteorological Service, 1974). Marlborough in particular suffered from a persistence of below average rainfall for seven successive months (New Zealand Meteorological Service, 1973). In November when 
ELIE BAY - WEATHER 1973

Rainfall, estimated evaporation and mean wind speed for each month. 
ELIE BAY

Weather 1973
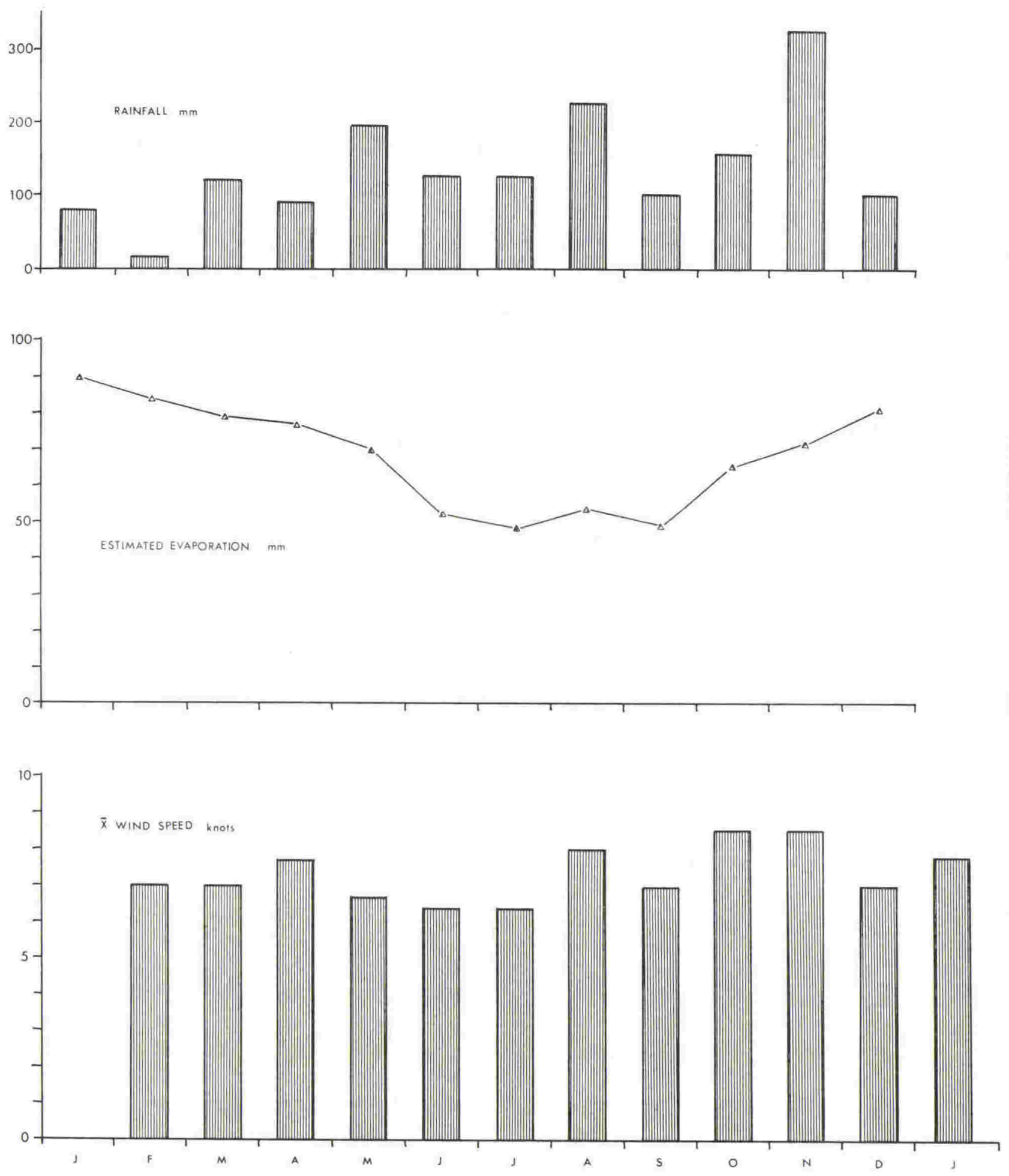
FIGURE 2.8

FIGURE 2.9

FIGURE 2.10

28 
FIGURE 2.8

DIURNAL WIND RHYTHM

Mean hourly values for wind speed over a twelve month period.

FIGURE 2.9

ELIE BAY - WIND ROSES

Wind direction expressed as a percentage for each month, as well as for the whole year. Recordings were made at 0800 hours.

FIGURE 2.10

WIND STRENGTH ACCORDING TO DIRECTION 


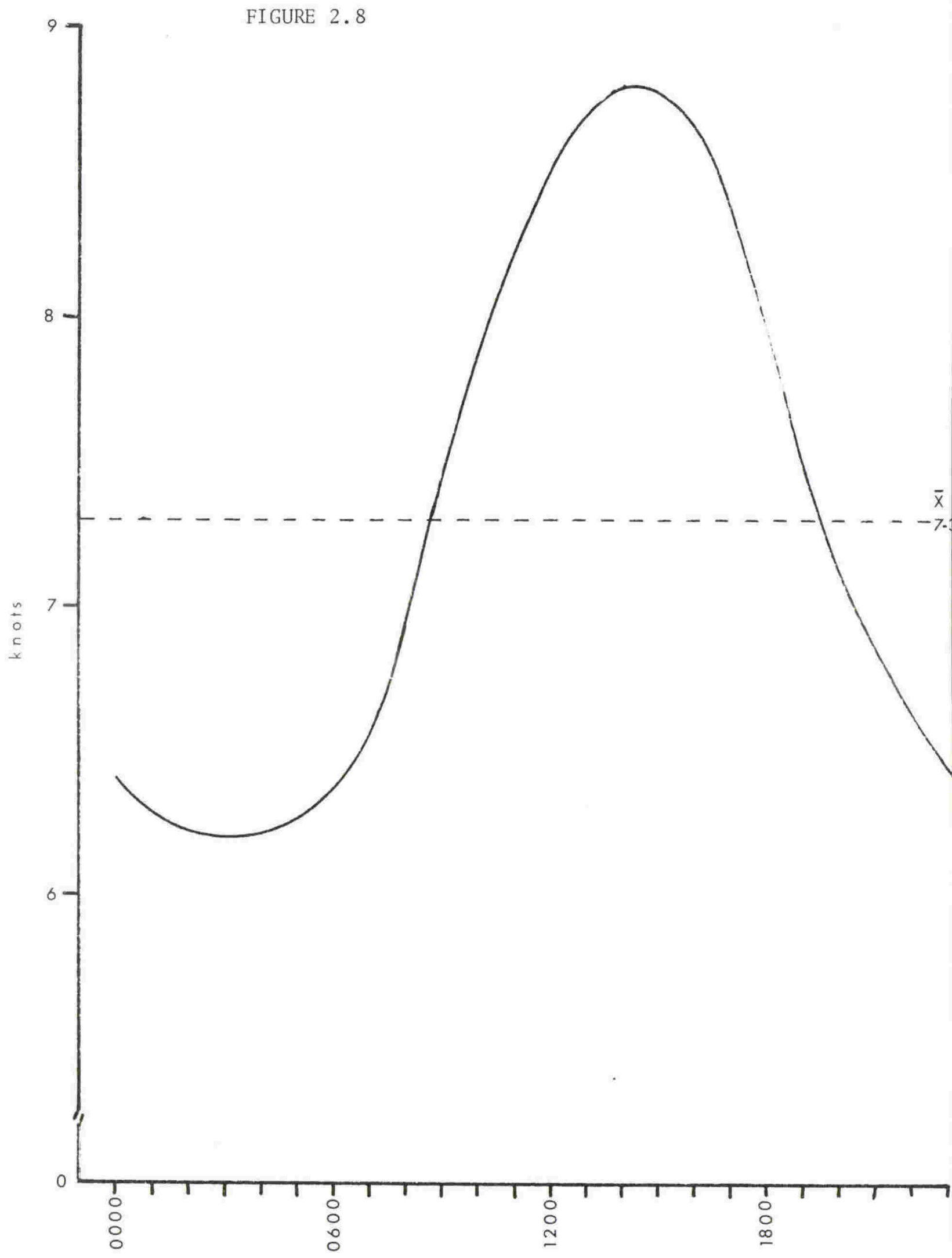



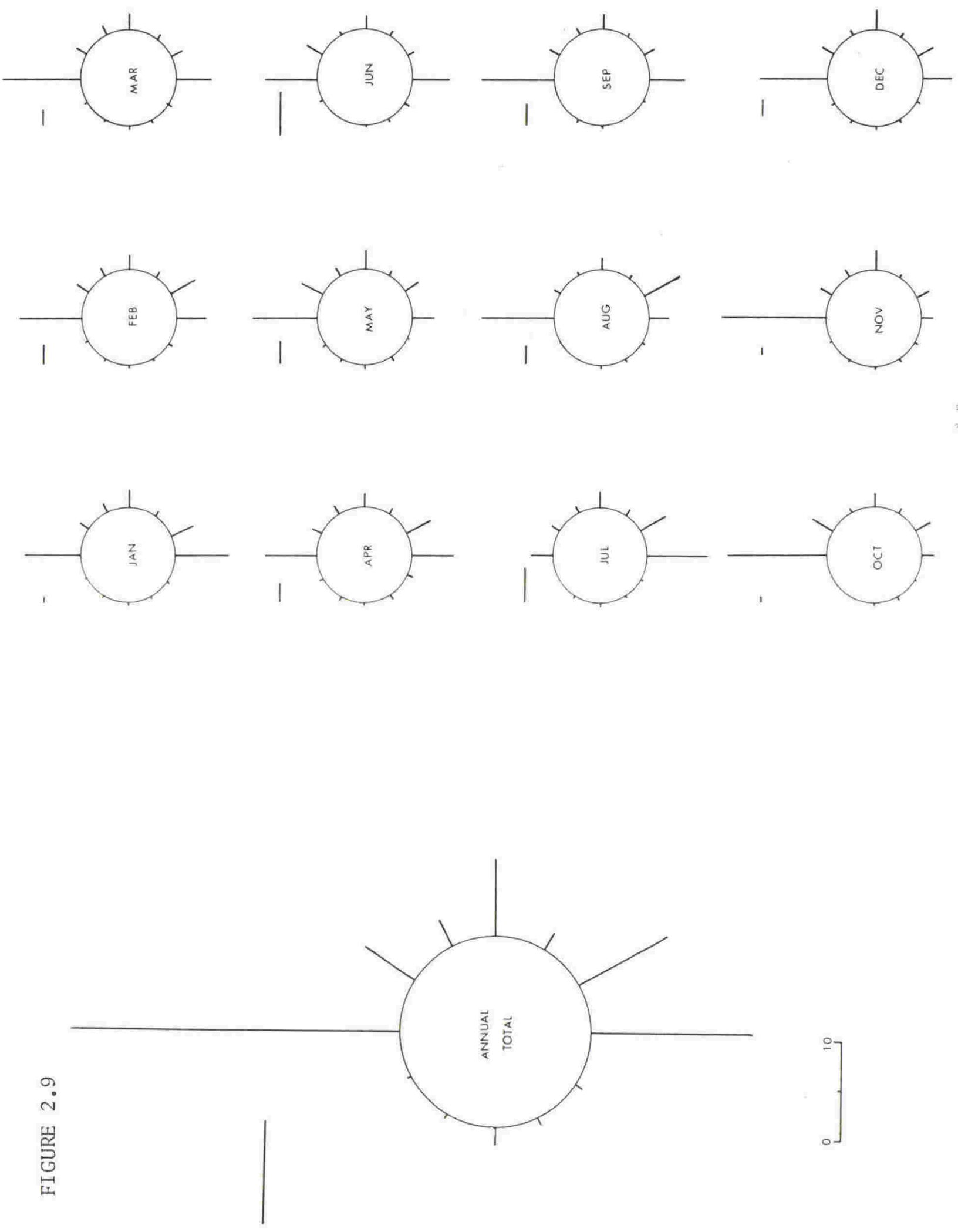


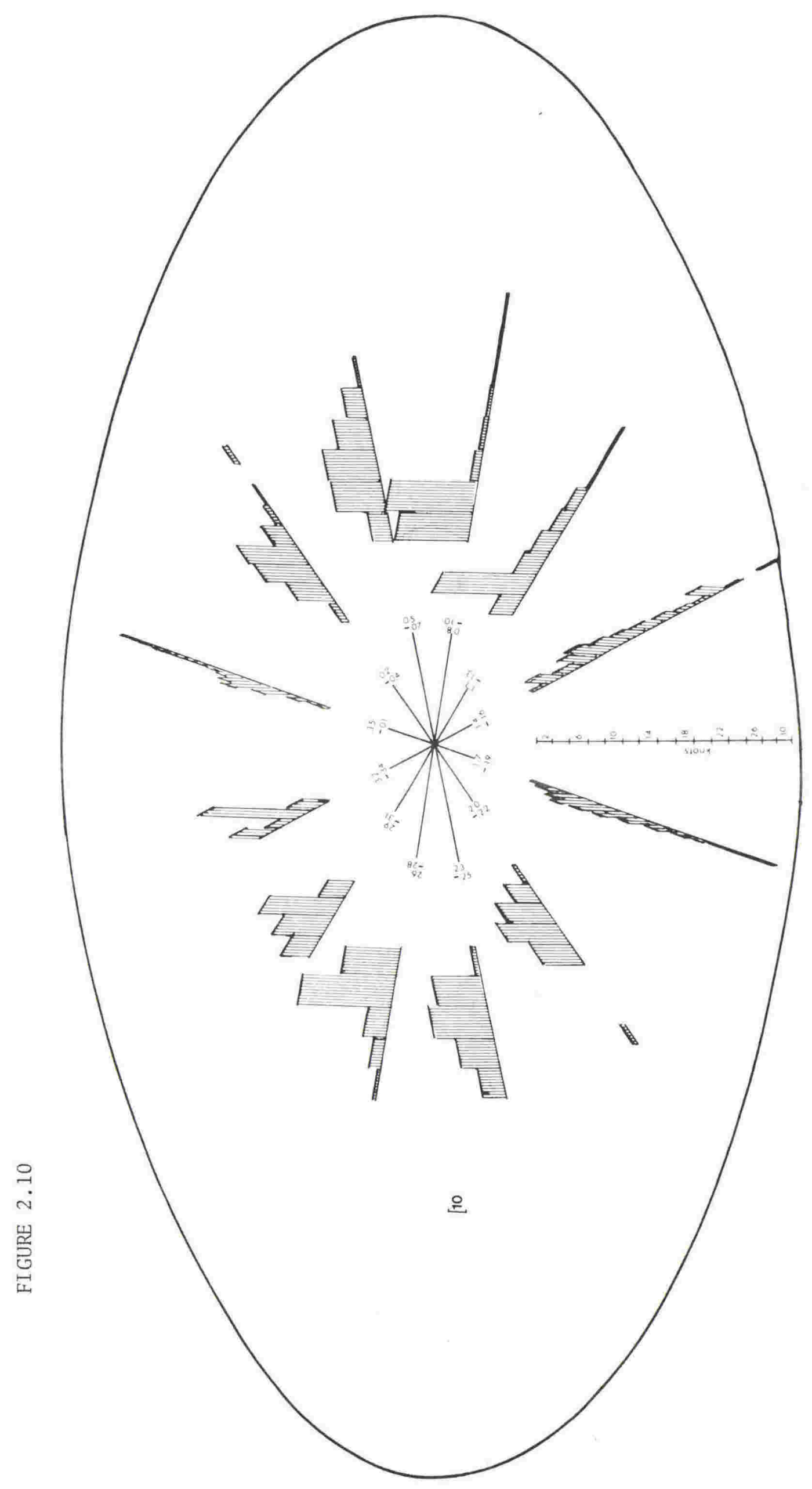


the dry period ended, rainfall was above average by more $\operatorname{than} 50 \%$.

A tentative rainfall distribution for the Marlborough Sounds during the study period is shown in Eigure 2.11. The figure was constructed from data recorded during 1973 and supplemented by past records made available by the New Zealand Meteorological Service. Elie Bay recorded $1558 \mathrm{~mm}$ with November being the wettest month and February the driest. Havelock at the head of the Sound appears to have been the driest area in Pelorus Sound while Waitaria in Kenepuru Sound had the maximum annual total. Another station which recorded a high rainfall was Rai Valley and, although inland, rainfall in this area influencés the Sound through the Pelorus River. The maximum precipitation over a 24-hour period occurred on May 13 at Picton with a southerly wind. The amount recorded on that occasion was 121mm. The maximum 24-hour precipitation at Elie Bay was $70 \mathrm{~mm}$ recorded on August 12 with a northerly wind.

The estimated total evaporation at Elie Bay for 1973 was $814 \mathrm{~mm}$. January with c. $90 \mathrm{~mm}$ showed the highest evaporation while July and September recorded the lowest with c. $50 \mathrm{~mm}$ (Figure 2.7). The total volume of evaporation estimated to have taken place from the water surface in the Beatrix Basin during 1973 was $41.25 \times 10^{6} \mathrm{~m}^{3}$. If the total freshwater gain by direct precipitation and stream run-off is 
MARLBOROUGH SOUNDS - RAINEALI DISTRIBUTION 1973 Isohyets constructed from data recorded by the stations indicated by red dots during 1973 and fitted according to past records made available by the N.Z. Meteorological Service. 


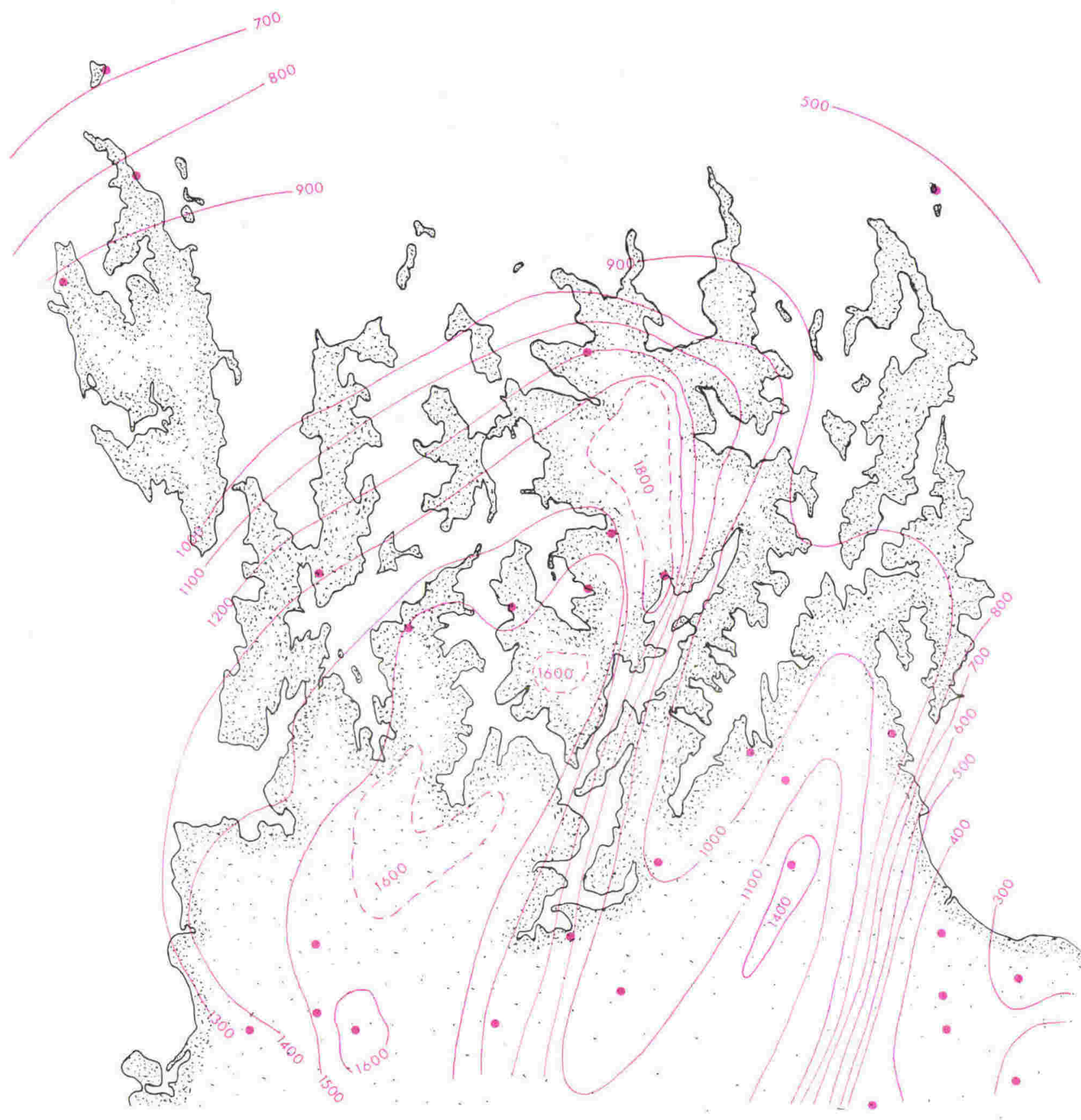

MARLBOROUGH SOUNDS

$+$

Rainfall Distribution 1973

isohyets at $100 \mathrm{~mm}$

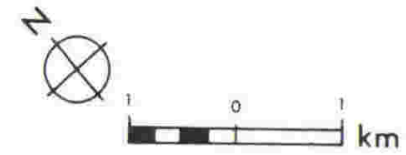


taken as about $218.5 \times 10^{6} \mathrm{~m}^{3}$, the loss by evaporation accounts for $18.9 \%$ (see Table 2.4 for explanation of freshwater gain).

As a result of the enclosed nature of the seatrix Basin There is no direct oceanic influence on the sea condition in the area. Heavy swell in cook strait might have an effect on the tidal conditions within the Basin but the only force responsible for wave generation is the local wind. Thus the sea condition is governed entirely by the wind and shows the same diurnal pattern as described above (Figure 2.8).

The maximum height of sea recorded at Elie Bay was $1.25 \mathrm{~m}$ which corresponds to a value of 3 on the standard scale (Table 2.1). The most exposed areas in the Beatrix Basin are the central and Clova Bay regions (Eastern) where waves of up to $2 \mathrm{~m}$ were experienced during the present study.

\section{3}

HYDROLOGY

\section{Methods}

Nine stations (see Table 2.2 and Figure 2.12) were sampled at the surface and at $10 \mathrm{~m}$, approximately monthly between November 1972 and October 1973. The water samples were obtained with a Nansen Bottle equipped with a reversing 
BEATRIX BASIN - HYDROLOGICAL STATIONS 


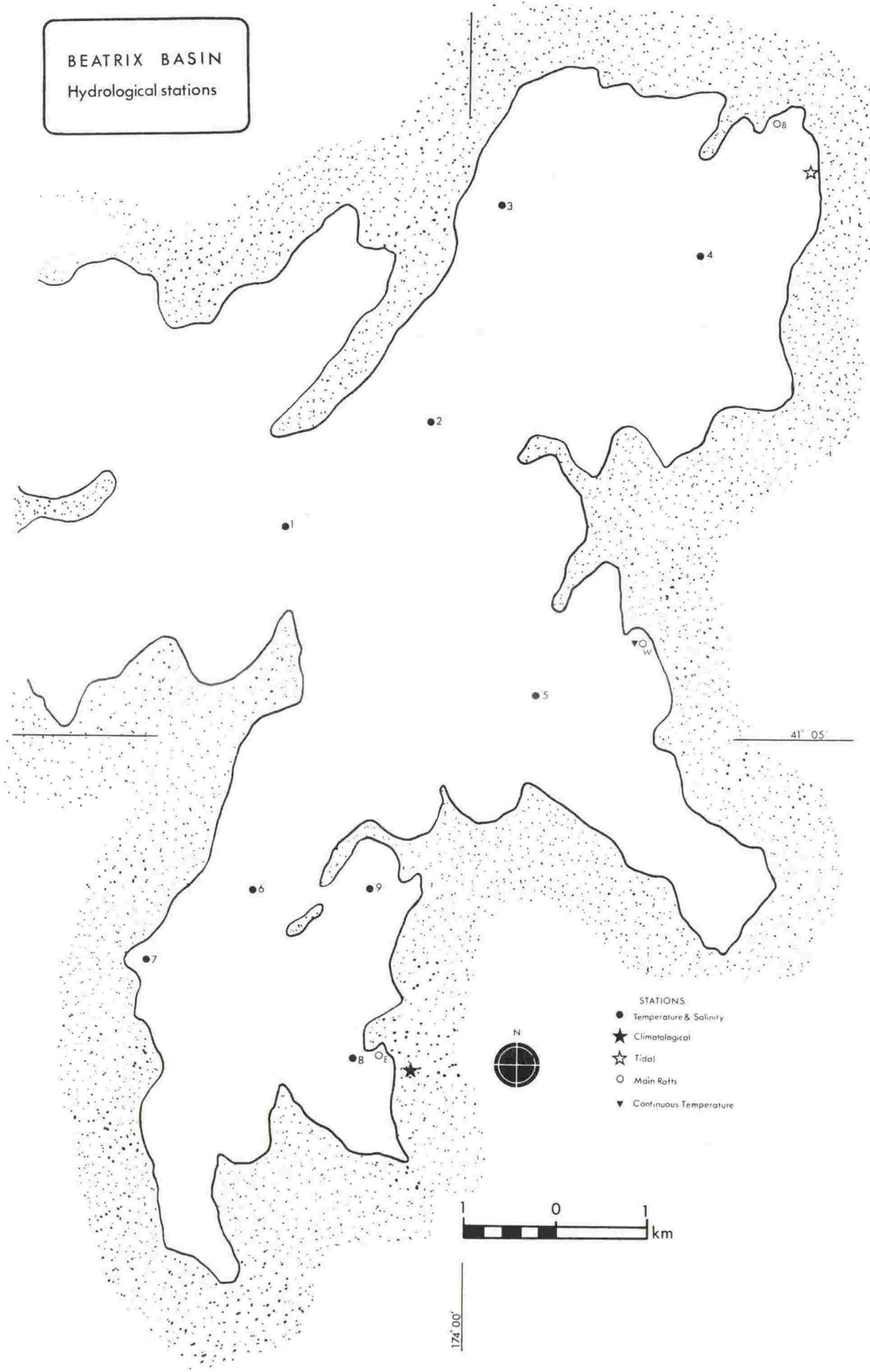


thermometer. Temperatures were read to the nearest $0.1^{\circ} \mathrm{C}$ and salinities determined to $0.01^{\circ} / 00$ using an Autolab Inductive Salinometer (Brown \& Hamon, 1961).

A Grant temperature recorder situated on the raft at Waimaru Bay was used to record hourly temperatures from five probes. The probes were set as follows:

1. surface - on mussel rope

2. surface - on flotation drum

3. at $3.5 \mathrm{~m}$ - on mooring chain

4. on the bottom - c. $6 \mathrm{~m}$

5. embedded in the bottom mud.

Drift cards and fluorescene dye were used to determine tidal flow patterns. Some 2000 drift cards sealed in plastic envelopes (Olsen, 1951) were released on a number of occasions over a period of 15 months within the Beatrix Basin and the immediate vicinity. Recovery rates were poor, especially in winter due to the remoteness of the area. However, a search of the beaches after one set of releases resulted in recovery rates of up to $86 \%$.

The fluorescene dye powder was packed in $150 \mathrm{~g}$ amounts and dropped from an aircraft at the rate of approximately four packets per kilometre (see Brodie, 1958). Movement of the dye patches was followed from the air for about 90 minutes (Plate 2.3). 


\section{FLUORESCENE DYE PATCHES}

A trail of dye patches is shown between Whakamawahi Pt and Opani-Aputa Pt (nearer observer) moving out of the study area during an ebbing tide. 


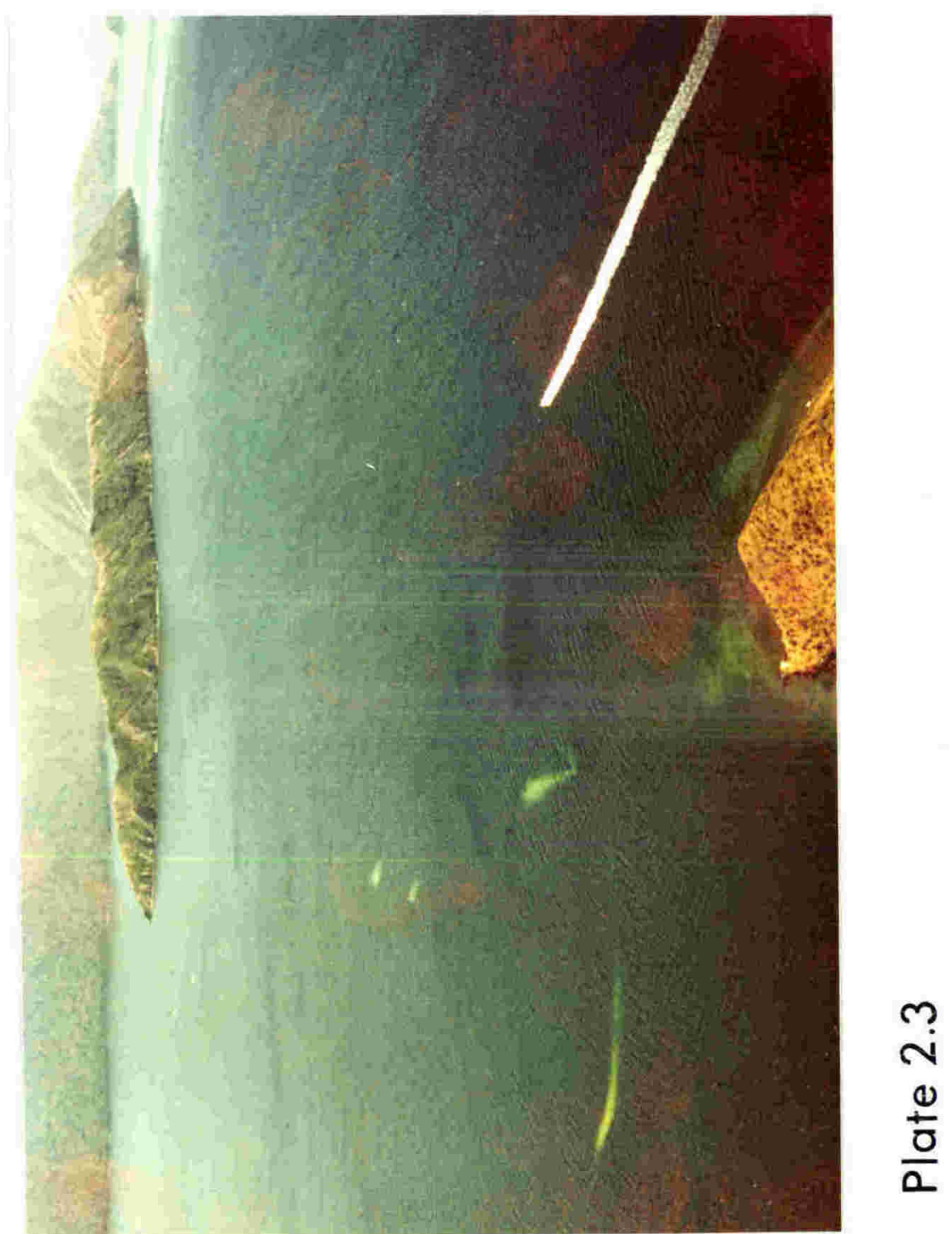


STATION

(1) Main entrance

(2) Beatrix entrance

(3) Beatrix west

(4) Beatrix east

(5) Clova entrance

(6) Crail entrance

(7) Crail west

(8) Elie

(9) Hopai
S

$41^{\circ} 04^{\prime}$

$41^{\circ} 035^{\prime}$

$41^{\circ} 015^{\prime}$

$41^{\circ} 023^{\prime}$

$41^{\circ} 053^{\prime}$

$41^{\circ} 06^{\prime}$

$41^{\circ} 07$,

$41^{\circ} 077^{\prime}$

$41^{\circ} 066^{\prime}$
E

$173^{\circ} 59^{\prime}$

$174^{\circ} 00^{\prime}$

$174^{\circ} 005^{\prime}$

$174^{\circ} 022^{\prime}$

$174^{\circ} 005^{\prime}$

$173^{\circ} 585^{\prime}$

$173^{\circ} 573^{\prime}$

$173^{\circ} 592^{\prime}$

$173^{\circ} 595^{\prime}$
DEPTH

$35 \mathrm{~m}$

$33 \mathrm{~m}$

$33 \mathrm{~m}$

$32 \mathrm{~m}$

$31 \mathrm{~m}$

$33 \mathrm{~m}$

$8 m$

$10 \mathrm{~m}$

$7 \mathrm{~m}$

\section{Results}

Monthly recordings for temperature and salinity from the surface and $10 \mathrm{~m}$ at each of nine stations in the Beatrix Basin are shown in Figures 2.13 and 2.14. Surface temperatures were higher than at $10 \mathrm{~m}$ in summer while the reverse occurred in winter at most stations. Two exceptions were stations 5 and 6 which recorded slightly higher temperatures at the surface both in winter and summer. Station 9 also showed this tendency but to a lesser extent. The difference between the surface and $10 \mathrm{~m}$ was usually less than $1^{\circ} \mathrm{C}$ and no thermocline was seen to be developed. Station 1 at the entrance to the Basin recorded the lowest summer temperature 
BEATRIX BASIN - TEMPERATURE AND SALINITY

Monthly temperature and salinity from the surface and $10 \mathrm{~m}$ at nine stations as below:

1 Main Entrance

2 Beatrix Bay Entrance

3 Beatrix Bay West

4 Beatrix Bay East

5 Clova Bay Entrance

6 Crail Bay Entrance

7 Crail West

8 Elie Bay

9 Hopai Bay

Means for the whole of Beatrix Basin are shown in the lower right figure. 
Beatrix Basin

Temperature $\stackrel{\square \longrightarrow 0 \text { suffice }}{\square-\square} 10 \mathrm{~m}$
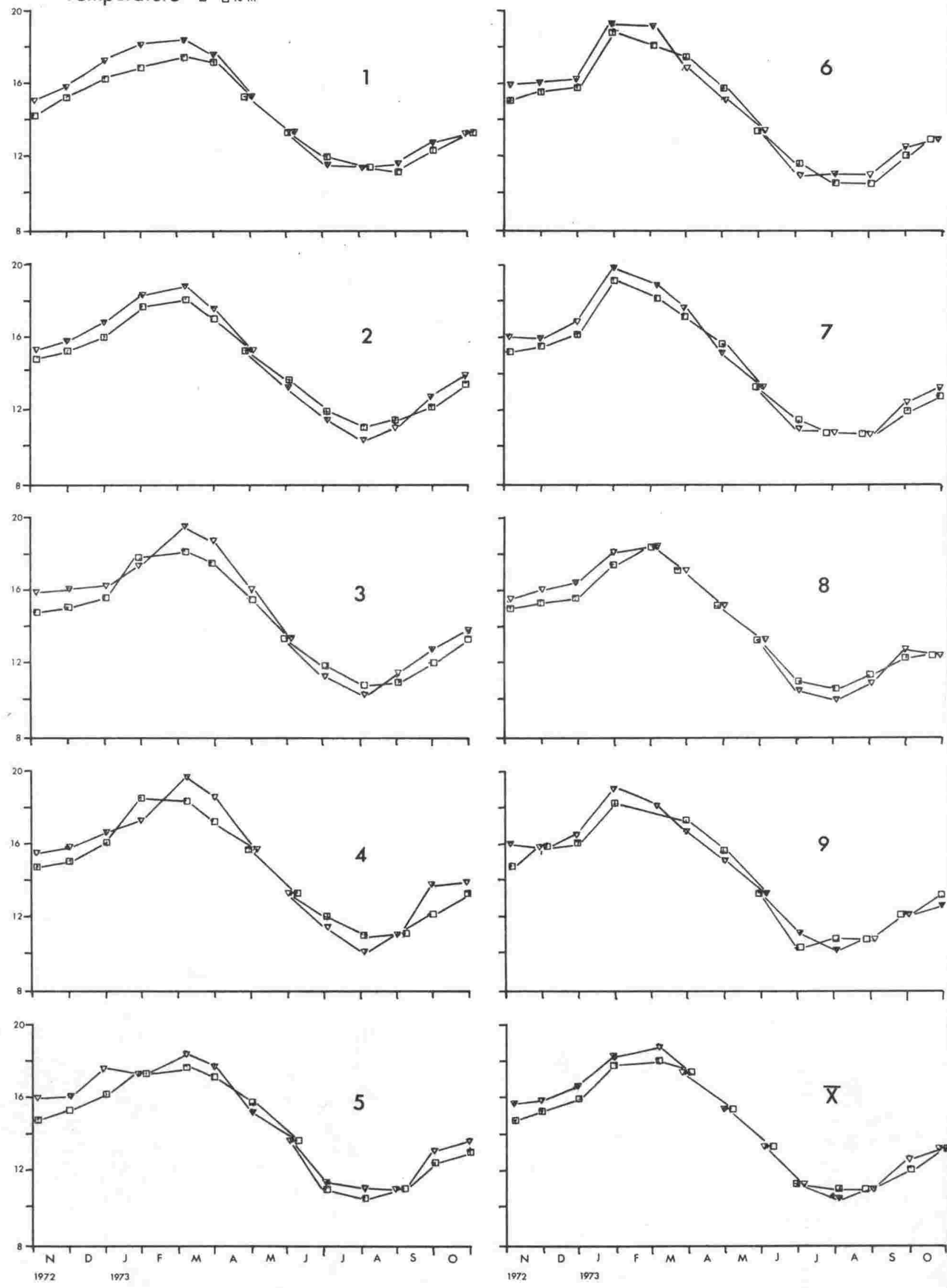
Beatrix Basin

Salinity $\%: 10 \mathrm{~m}$
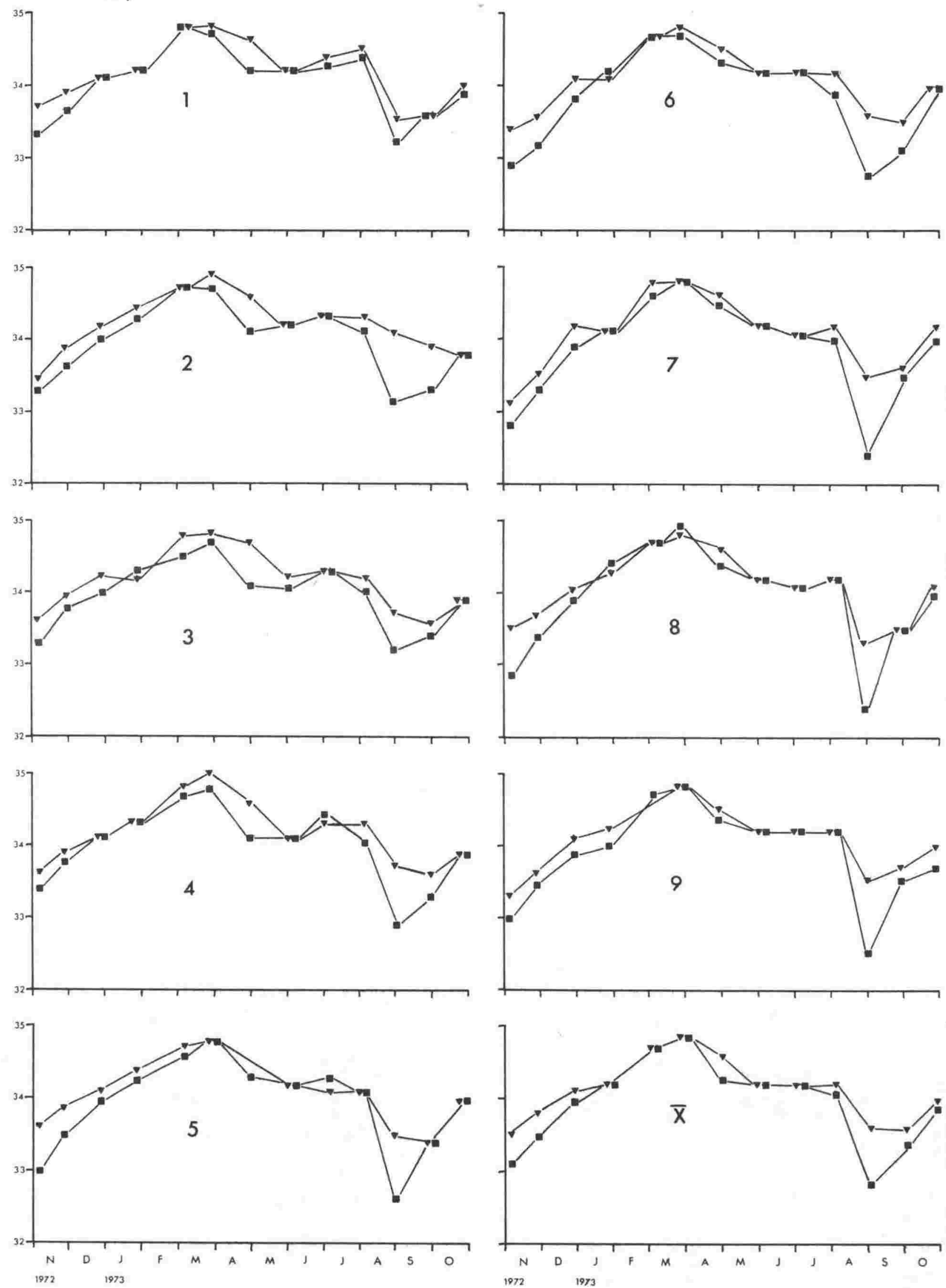
and the highest winter temperature thus this station had the lowest temperature fluctuation in the study area $\left(7.3^{\circ} \mathrm{C}\right)$. The reverse occurred in the sheltered southern stations 7 and 8 .

Salinities in general were lower at the surface than at a depth of $10 \mathrm{~m}$ but no halocline was present. In August 1973 all surface stations recorded a drop in salinity after heavy rain. Station 1, however, also recorded an equivalent drop at $10 \mathrm{~m}$. This could be an indication of the mixing which is presumed to take place at this station. The highest overall salinity recorded was $35^{\circ} / 00$ at station 4 from $10 \mathrm{~m}$. The lowest salinity was $32.4^{\circ} / 00$ and occurred at stations 7 and 8 at the surface. Stations 1 and 3 recorded the narrowest range in salinity throughout the year, while station 8 had the widest range.

Following exceptionally heavy rain in early April 1975, recordings made 24 hours after the rain had stopped showed the following salinities at the surface:

$\begin{array}{ll}\text { Tawero Pt } & 24.5^{\circ} / 00 \\ \text { Whakamawahi Pt } & 31.5^{\circ} / 00 \\ \text { Raft B (Saratoga) } & 29.3^{\circ} / 00 \\ \text { Raft W (Waimaru) } & 30.8^{\circ} / 00 \\ \text { Raft E (Elie) } & 31.1^{\circ} / 00 \\ \text { Wet Inlet } & 14.5^{\circ} / 00\end{array}$


Temperature means from hourly recordings at five levels in the water column during the months of February, April, July, and November are shown in Figure 2.15. No record was available from probe 3 (mid-water) in February, and probe 1 (surface, on rope) in April, due to failure of the instrument. There was no significant temperature difference between the mussel rope and the flotation drum, both of which were in the top $10 \mathrm{~cm}$ of water. There was a decrease in temperature with depth in summer and the mud was colder than the surface by just over $1^{\circ} \mathrm{C}$. This difference was greatly reduced in autumn and completely reversed in winter when the mud became the warmest. The temperature gradient assumed the summer pattern by November except that the mud was still not the coldest by then. A diurnal temperature rhythm existed on the surface throughout the year although the range was reduced in autumn and minimal $\left(0.4^{\circ} \mathrm{C}\right)$ in winter. The lower levels did not register a diurnal rhythm in winter.

Not all drift card recoveries were regarded as significant due to the scarcity of returns from some releases and/or the period of time between release and recovery. Table 2.3 summarizes nine releases which were considered reliable. The effect of wind on the surface water circulation is very marked (Figures 2.16, 2.17 and 2.18) and overrides the tidal flow on the surface. It was interesting to note that when the wind was sufficiently light, 
WAIMARU RAFT - TEMPERATURES

Mean hourly temperatures from 5 probes at four times of the year. 


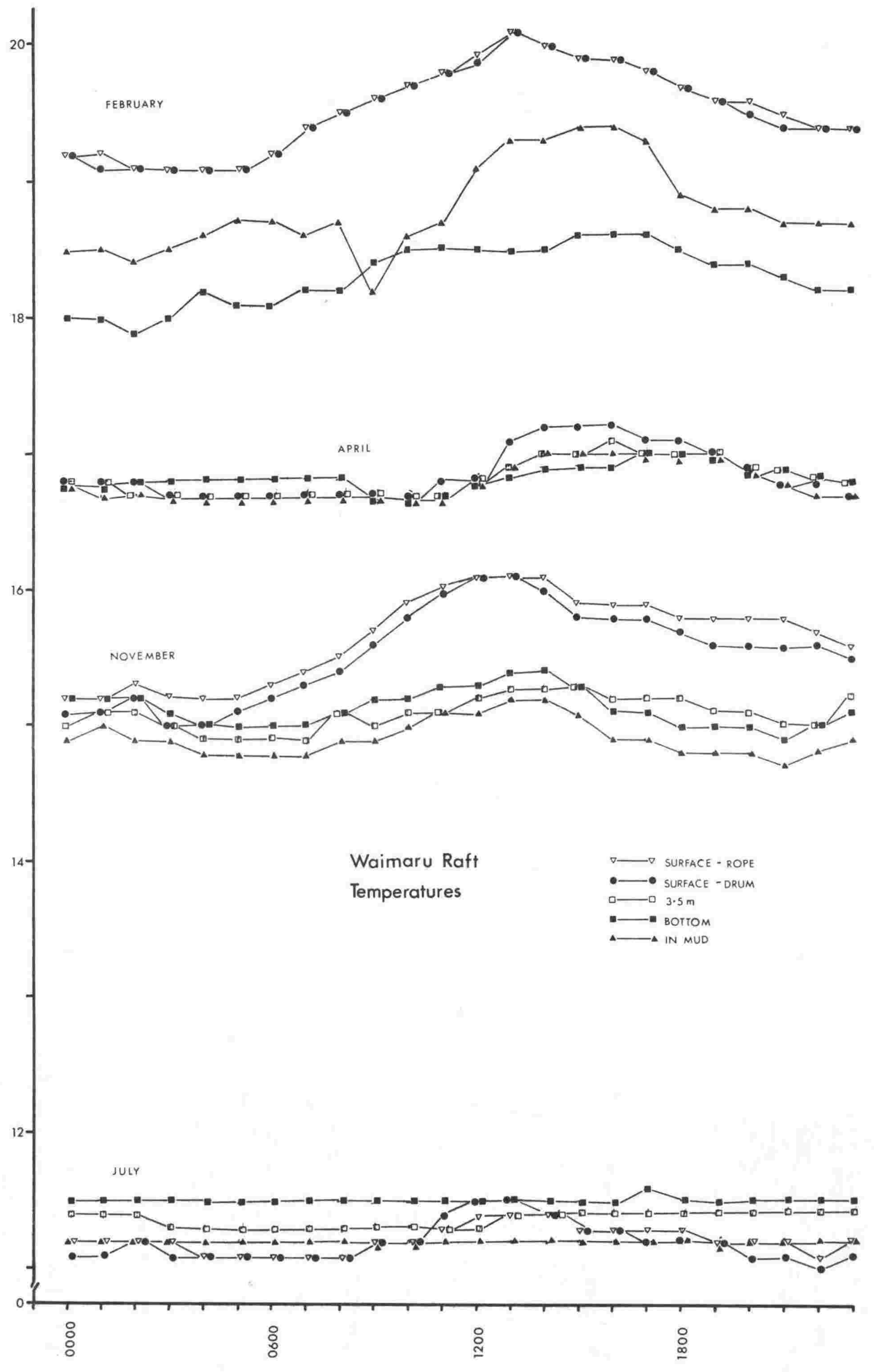




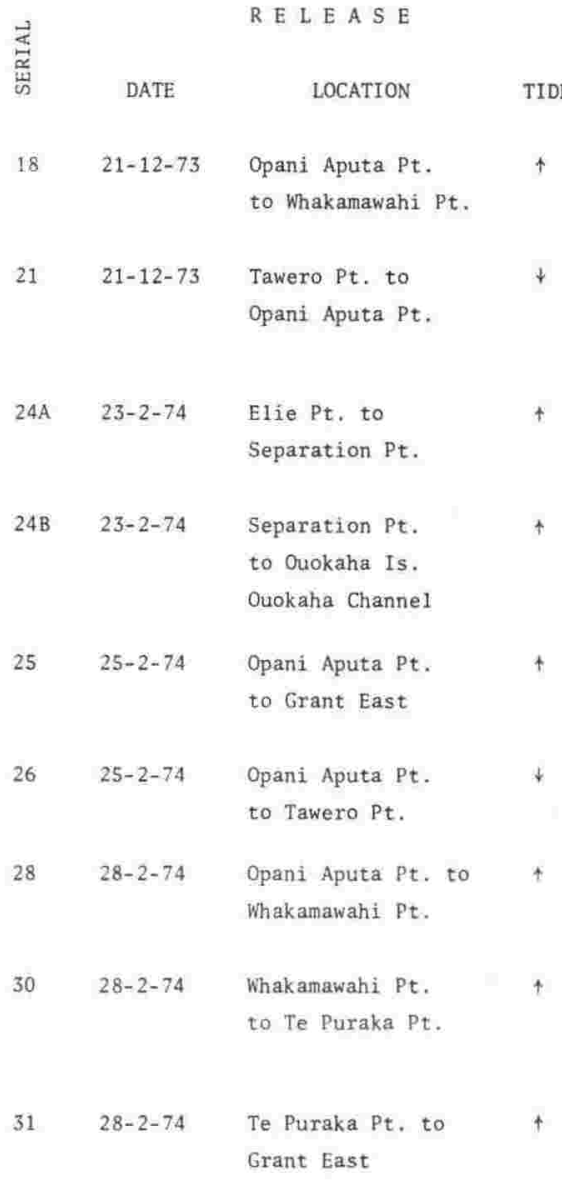

WIND
HISTORY
S-SE $\bar{X} 10 \mathrm{kn}$
for 2 days;
$V$ (Mainly S) $\bar{X}$
$9 \mathrm{kn}$ for 4 days;
$N \bar{X} 10 \mathrm{kn}$ (Max
$14 \mathrm{kn}$ ) for 6 days

RECOVERY

$$
\begin{array}{cc}
\bar{X} & \text { PROBABLE } \\
\% & \text { DAYS } \\
\text { DRIFT PATHS }
\end{array}
$$

$18 \quad 6 \quad$ Fig $2.17 \mathrm{~B}$

All cards carried against the tide with wind up Waitata Reach

$26 \quad 12 \quad$ Fig 2.16A

Cards carried by wind except from shelter of Opani Aputa Pt.

\section{No wind}

for 1 day;

$\checkmark \bar{X} 5 \mathrm{kn}$ for

3 days; $S 20 \mathrm{kn}$

1 day; $V$ (Mainly

N) $\bar{x} 4 \mathrm{kn} 2$ days

$$
56
$$

Fig 2.18B

73

Fig 2.18A

Fig $2.18 \mathrm{~A}$

$\mathrm{V} \overline{\mathrm{X}} 5 \mathrm{kn} 1$ day;

S $\bar{X}$ 20kn I day;

$V$ (Mainly $N$ )

$\bar{X} 4 \mathrm{kn}$ for 2 days

$\checkmark$ light for

2 days; $S \bar{X}$

$16 \mathrm{kn}$ for 1 day;

S storm Max

$28 \mathrm{kn}$ for 5 days
Fig 2.17A

$4 \quad 36$

$12 \quad 13$

$27 \quad 10$

$48 \quad 4$

Fig $2.18 \mathrm{C}$

49
Fig 2.16B

Fig $2.18 D$

Fig 2,18B
With tide into Bay - would have

refloated if not collected

With tide into Bay as above

Caught in counter-clockwise pattern

Carried out and scattered by wind against tide

No wind effect - probably stranded earlier by tide

No wind effect - one card caught in countercurrent around Whakamawahi pt.

Light wind enough to deflect all cards apart from those in lee of Whakamawahi $P t$.

Moved with wind and tide 
some cards released near the entrance to the Beatrix Basin on the falling tide were actually swept into the Basin (Figure 2.16B, release 26).

Dye patches on the rising and falling tides were used on two occasions and the results were conflicting. The reason for the discrepancy lies again with the wind conditions at the time of the experiment. In 1973 conditions were calm while during the 1974 experiment there was a 15 knot northwesterly wind.

Under calm conditions the flood tide resulted in a simple circulation pattern with counter-clockwise currents in both Beatrix Bay and Crail Bay (Figure 2.19A). The circulation in Beatrix Bay was observed with the aid of dye patches not recorded in the figure. Crail Bay circulation was deduced from dye traces 5 and 6 in Figure 2.20A as well as by the missing drift cards in Figure 2.18A.

When the ebbing tide was not influenced by the wind (Figure 2.19B) the water mass flowing down Pelorus Sound was partially diverted into the Beatrix Basin by Tawero Pt. This wedge extended some distance southwards into Crail Bay on the surface.

A slick, about $5 \mathrm{~km}$ long, made up of flotsam and innumerable Aurelia aurita medusae, showed the convergence of the two masses of water. 
FIGURE 2.16

FIGURE 2.17

FIGURE 2.18

42 
DRIFT CARD RECOVERIES AND POSSIBLE PATHS

The effect of wind and tide on drift cards

released within Beatrix Basin and its

immediate vicinity. See Table 2.3 for details. 

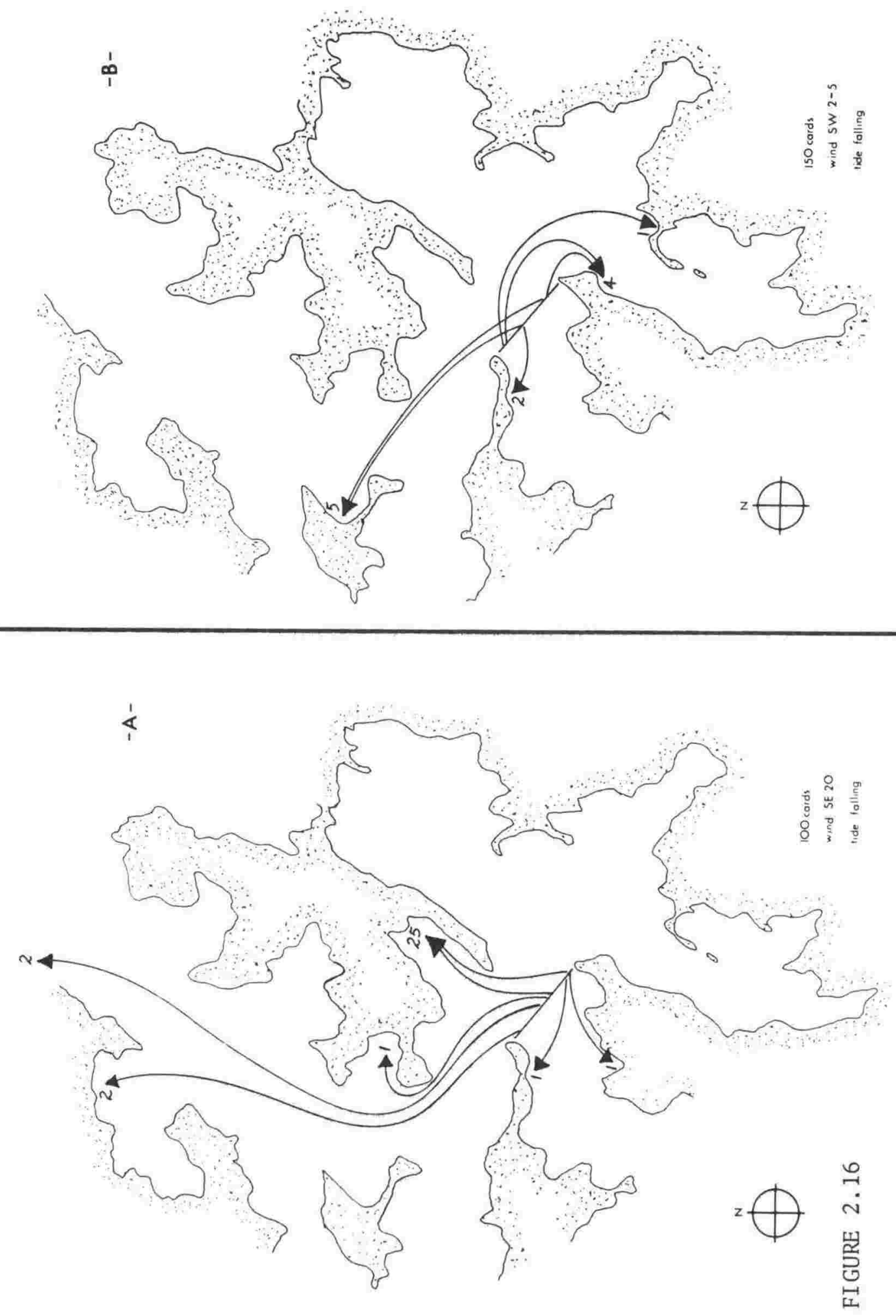

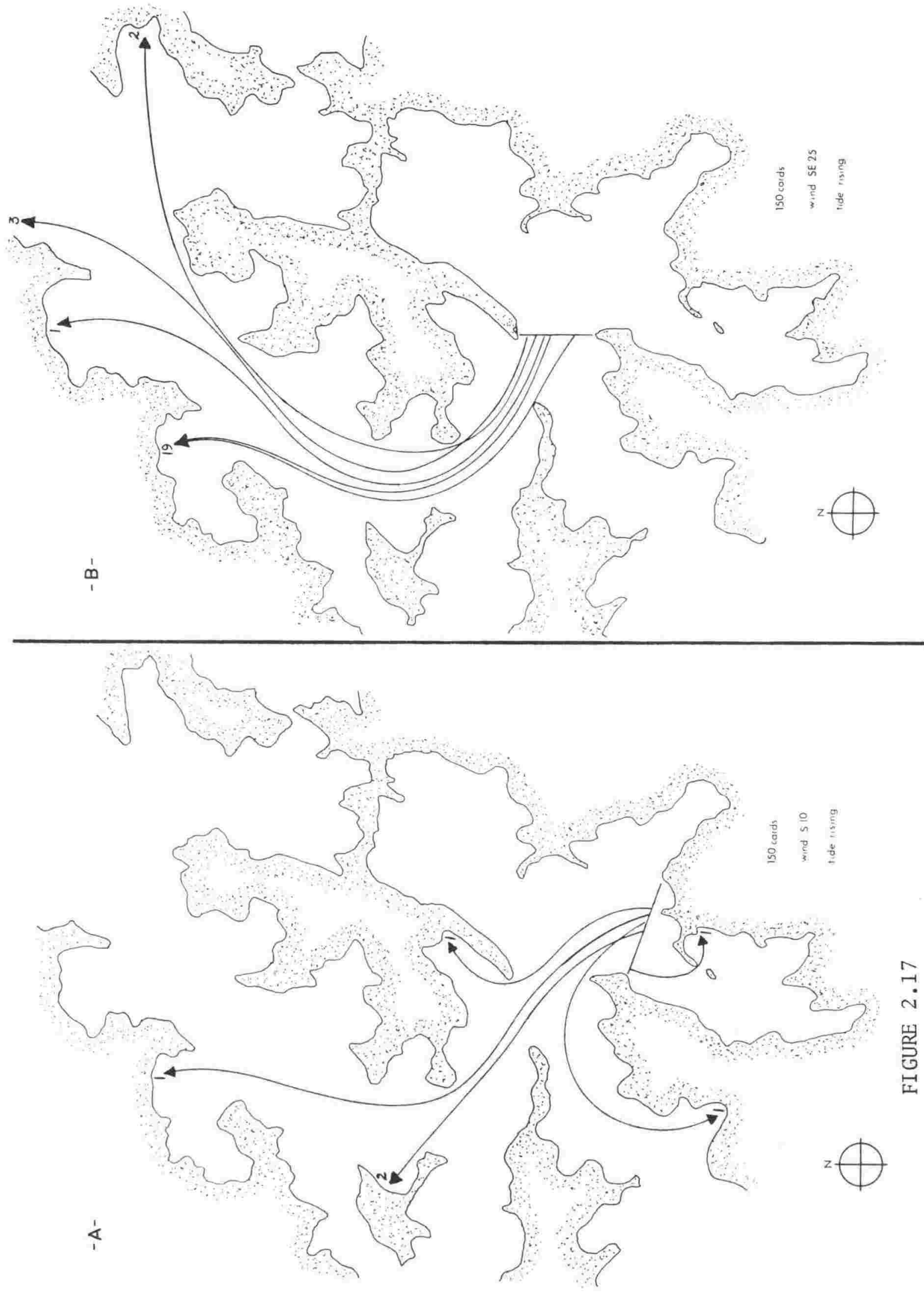

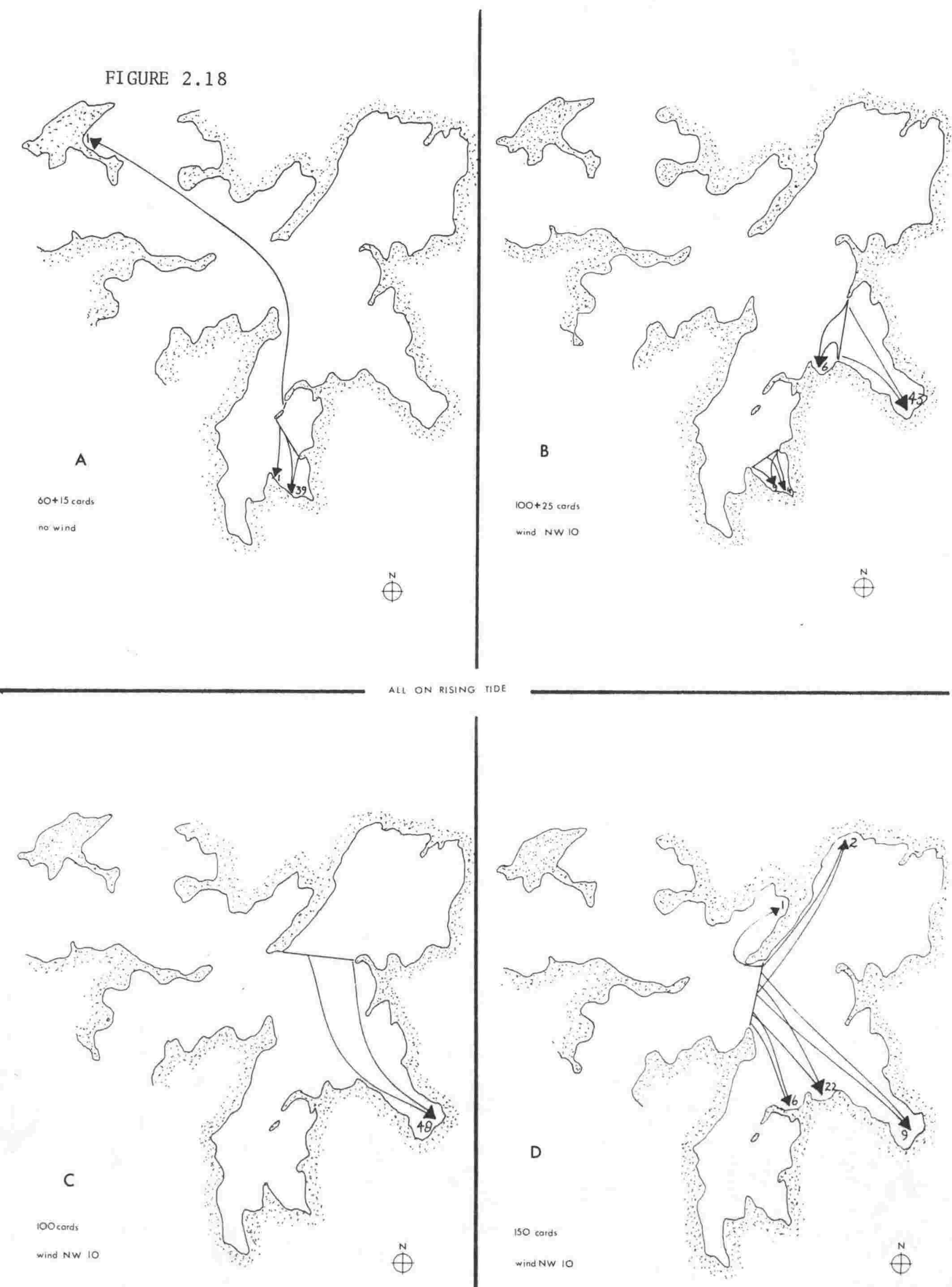
In 1974 a northwesterly wind of 15 knots was sufficient to disturb the patterns noted above on both the incoming and outgoing tides (Figure 2.20). Surface water was driven out of Beatrix Bay by the wind against the rising tide (trace 2 Figure 2.20A), while at the entrance to the Basin the wedge of inner-Sound water described above failed to flow into the study area. In fact the wind drove the water coming out of Crail Bay southwards into Little Homewood Bay (Figure 2.20B).

Garner \& Ridgway (1955) and Heath (1973) encountered similar wind effects during their work in lyttelton Harbour and Tasman Bay respectively. According to Hughes (1956) and Ridgway (1960) the surface water drifts on average with $2.2 \%$ of the wind speed in the same direction. Although the wind factor is expected to be reduced near coastlines where tidal streams are present (Bowden, 1953) it seems that in the study area the surface flow is strongly influenced by the wind.

Figure 2.21 shows the resultant surface water circulation when not influenced by the wind. No information on subsurface circulation is available but this is expected to be rather complex with a possibility of internal tides occurring (Heath, pers. comm.). 
MOVEMENT OF DYE TRACES

Dye traces laid in straight lines as indicated, on the rising tide as well as the falling tide, were carried by wind and tide in the directions shown. 


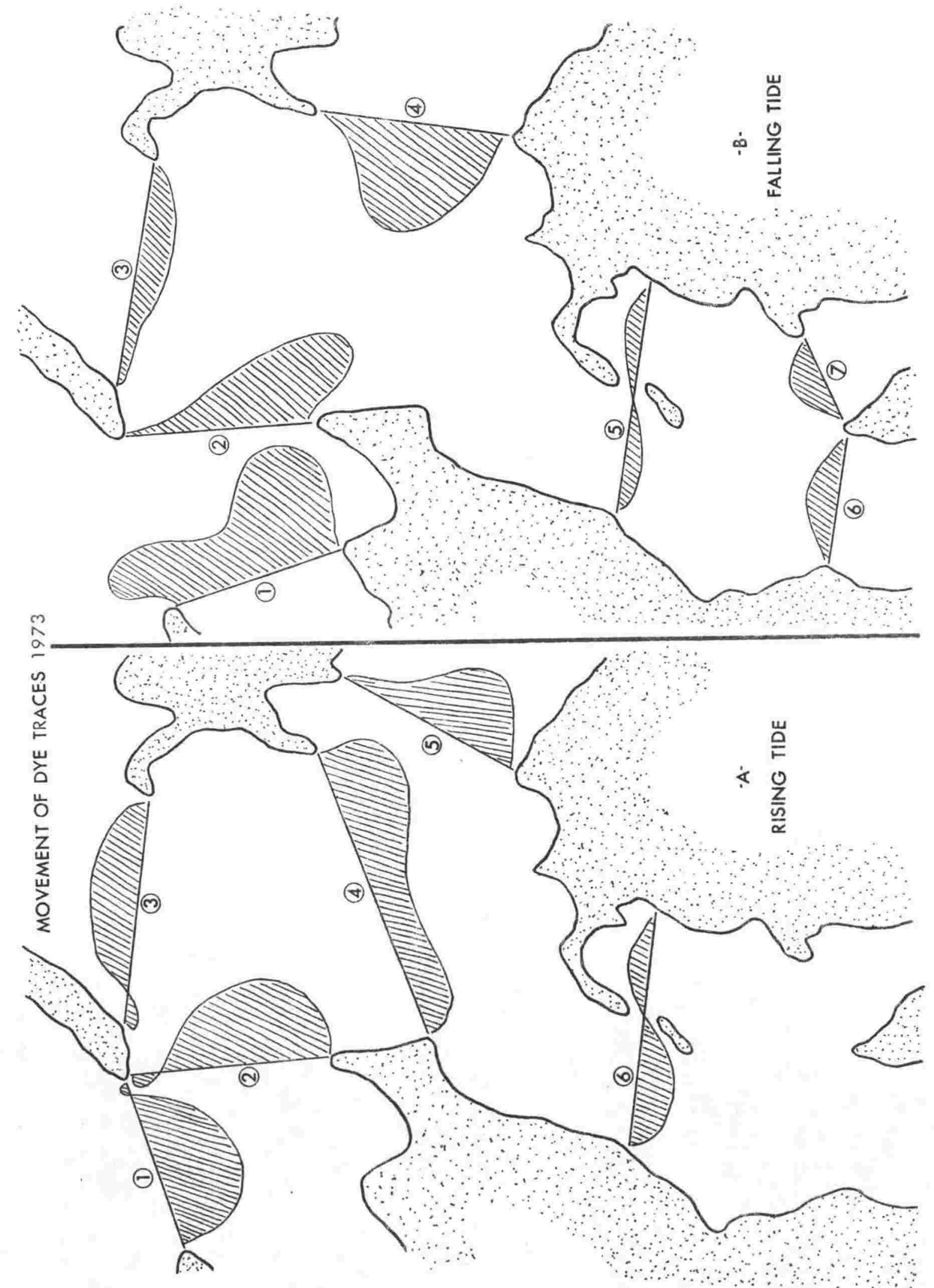




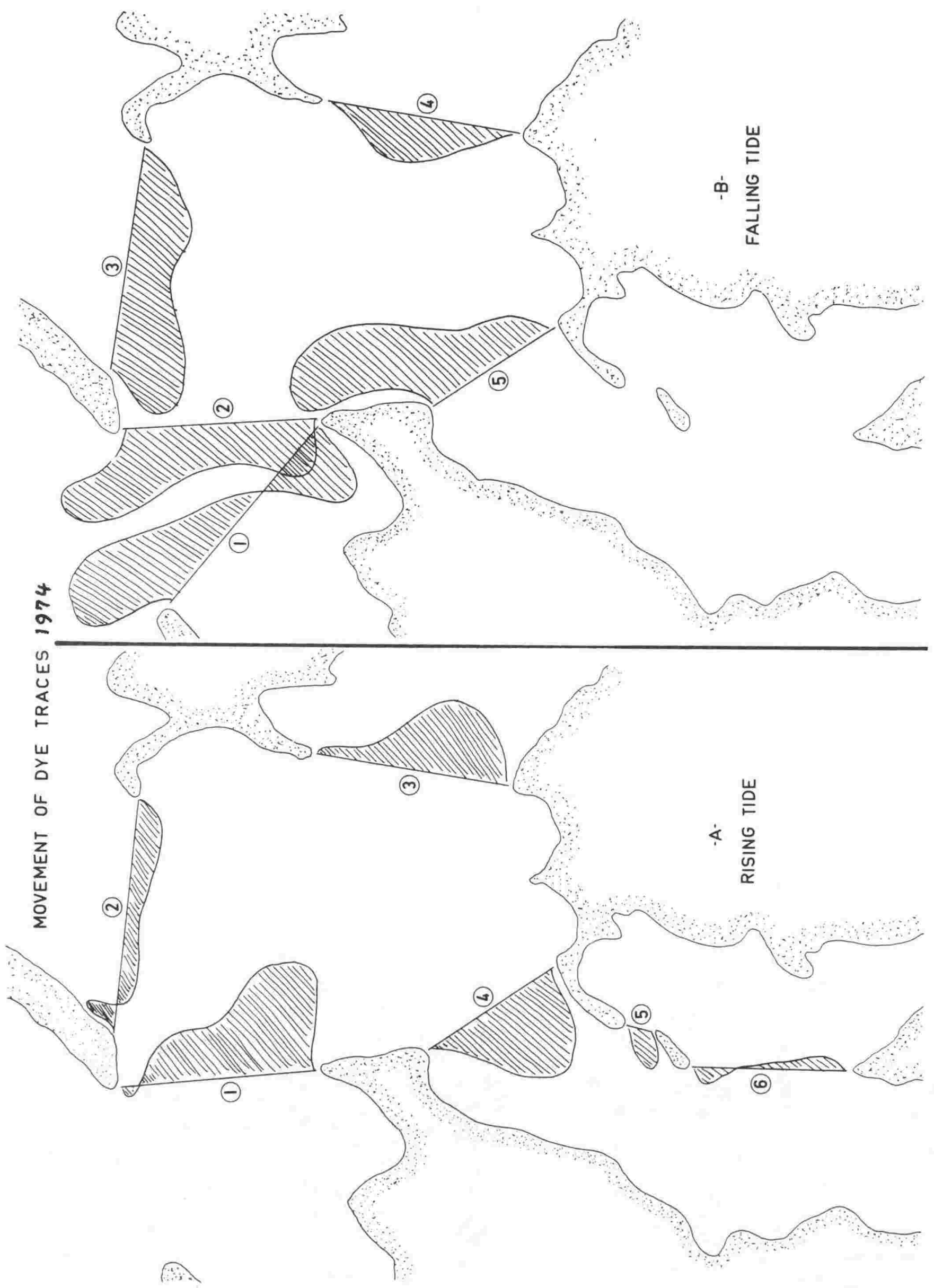


TIDAL CIRCULATION IN BEATRIX BASIN

Surface water movement as deduced from drift cards and dye patches without the influence of wind. 


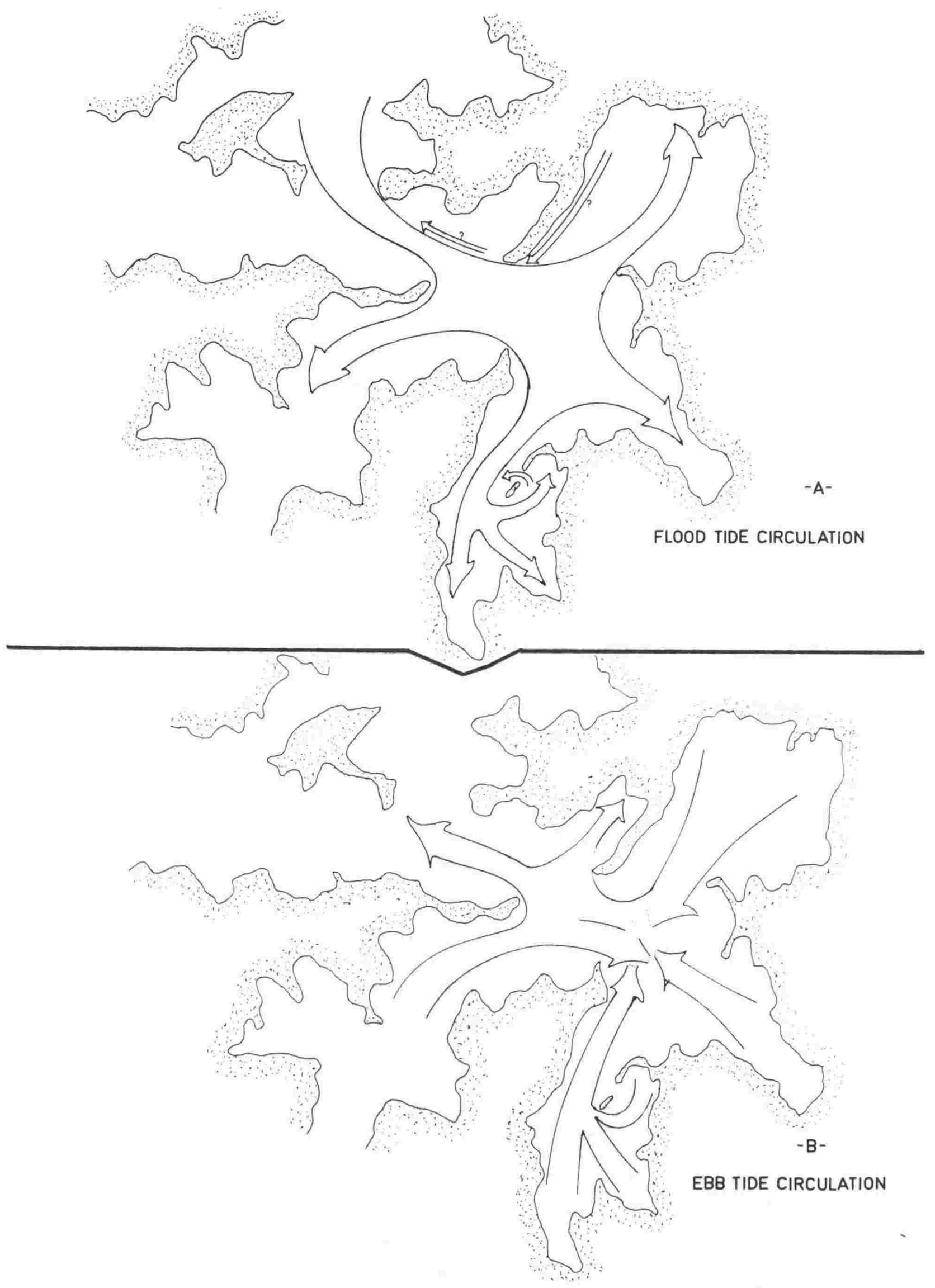


The physical characteristics of the four regions within the Beatrix Basin appear in Table 2.4. Many differences are noticeable between the regions, some quite insignificant, others like the degree of exposure, can be very important to the prospective marine farmer. Physical characters are the only ones discussed here. A comprehensive assessment is found in section Four.

The Northern Region (see Figure 2.3) is composed mainly of a wide water surface area with moderate exposure all round except for the eastern side where Mt Stokes affords some shelter. Entrance to the region is by way of a $2.2 \mathrm{~km}$ opening facing south. It is from this direction that the sea is subject most to the influence of the wind. Some areas sheltered from the southerly influence are exposed to the northerly winds, but seas from this latter direction are seldom important. Areas offering some shelter are Laverique Bay and Tuhitarata Bay as well as the small bays on the western shores of the region. Rainfall in the area is lower than in other parts of Beatrix Basin due to its proximity to Cook Strait. This, coupled with a relatively small catchment area, results in only minor effect on salinity after heavy rain. Mean depth of the area is about $32 \mathrm{~m}$ and the bottom is virtually flat with a gentle northward slope. The sublittoral shore is steep on the western side but alluvial deposits 
TABLE 2.4 PHYSICAL OBSERVATIONS

\begin{tabular}{|c|c|c|c|c|c|}
\hline & NORTHERN & EASTERN & SOUTHERN & CENTRAL & BEATRIX \\
\hline & REGION & REGION & REGION & REGION & BASIN \\
\hline $\begin{array}{l}\text { Water surface } \\
\text { (M.S.L.) }\end{array}$ & $17.35 \mathrm{~km}^{2}$ & $5.6 \mathrm{~km}^{2}$ & $12.8 \mathrm{~km}^{2}$ & $15.0 \mathrm{~km}^{2}$ & $50.75 \mathrm{~km}^{2}$ \\
\hline $\begin{array}{l}\lambda \text { depth of } \\
\text { water }\end{array}$ & $32 \mathrm{~m}$ & $25 \mathrm{~m}$ & $25 \mathrm{~m}$ & $30 \mathrm{~m}$ & $27.5 \mathrm{~m}$ \\
\hline $\begin{array}{l}\text { Mudflat area } \\
\text { (M.L.W.) }\end{array}$ & $<1.0 \mathrm{~km}^{2}$ & c. $1.0 \mathrm{~km}^{2}$ & c. $1.0 \mathrm{~km}^{2}$ & - & c. $2.5 \mathrm{~km}^{2}$ \\
\hline $\begin{array}{l}\text { Water volume } \\
\text { (M.S.L.) }\end{array}$ & $520.5 \times 10^{6} \mathrm{~m}^{3}$ & $140 \times 10^{5} \mathrm{~m}^{3}$ & $320 \times 10^{6} \mathrm{~m}^{3}$ & $450 \times 10^{6} \mathrm{~m}^{3}$ & $1430.5 \times 10^{6} \mathrm{~m}^{3}$ \\
\hline $\begin{array}{l}\text { Tidal compartment } \\
(\overline{\mathrm{X}} \text { amplit. }=2 \mathrm{~m})\end{array}$ & $34.7 \times 10^{6} \mathrm{~m}^{3}$ & $11.2 \times 10^{6} \mathrm{~m}^{3}$ & $25.6 \times 10^{6} \mathrm{~m}^{3}$ & $30 \times 10^{6} \mathrm{~m}^{3}$ & $101.5 \times 10^{6} \mathrm{~m}^{3}$ \\
\hline $\begin{array}{l}\text { : turnover } \\
\text { each tide }\end{array}$ & $6.6 \%$ & $8 \%$ & $8 \%$ & $6.6 \%$ & $7.3 \%$ \\
\hline $\begin{array}{l}\text { Catchment area } \\
\text { (incl. water surface) }\end{array}$ & $33.85 \mathrm{~km}^{2}$ & $50.6 \mathrm{~km}^{2}$ & $44.0 \mathrm{~km}^{2}$ & $15.0 \mathrm{~km}^{2}$ & $143.45 \mathrm{~km}^{2}$ \\
\hline $\begin{array}{l}\text { Estimated } \\
\text { rainfal1 } 1973\end{array}$ & $1300 \mathrm{~mm}$ & $1450 \mathrm{~mm}$ & $1550 \mathrm{~mm}$ & $1350 \mathrm{~mm}$ & $1412.5 \mathrm{~mm}$ \\
\hline $\begin{array}{l}\text { Theoretical } \\
\text { freshwater inflow* }\end{array}$ & $36 \times 10^{6} \mathrm{~m}^{3}$ & $53 \times 10^{5} \mathrm{~m}^{3}$ & $47.75 \times 10^{6} \mathrm{~m}^{3}$ & $21.25 \times 10^{6} \mathrm{~m}^{3}$ & $158 \times 10^{6} \mathrm{~m}^{3}$ \\
\hline $\begin{array}{l}\bar{X} \text { surface } \\
\text { salinity }\end{array}$ & $33.97^{\circ} / 00$ & $33.85^{\circ} / 00$ & $33.88^{\circ} / 00$ & $34^{\circ} \% 00$ & $33.92^{\circ} / 00$ \\
\hline $\bar{x} 10 \mathrm{~m}$ salinity & $34.16^{\circ} / 00$ & $34.06^{\circ} / 00$ & $34.06^{\circ} / 00$ & $34.18^{\circ} / 00$ & $34.11^{\circ} / 00$ \\
\hline $\begin{array}{l}\bar{X} \text { surface } \\
\text { temperature }\end{array}$ & $15.0^{\circ} \mathrm{C}$ & $14.9^{\circ} \mathrm{C}$ & $14.7^{\circ} \mathrm{C}$ & $14.8^{\circ} \mathrm{C}$ & $14.85^{\circ} \mathrm{C}$ \\
\hline $\begin{array}{l}\bar{x} 10 \mathrm{~m} \\
\text { temperature }\end{array}$ & $14.5^{\circ} \mathrm{C}$ & $14.4^{\circ} \mathrm{C}$ & $14.4^{\circ} \mathrm{C}$ & $14.5^{\circ} \mathrm{C}$ & $14.45^{\circ} \mathrm{C}$ \\
\hline $\begin{array}{l}\text { Wind } \\
\text { exposure }\end{array}$ & $\begin{array}{l}\text { Moderate from } \\
N, N W, S, S W\end{array}$ & $\begin{array}{l}\text { High from } \\
N, N W, W, S, S E, E\end{array}$ & $\begin{array}{l}\text { Low from } \\
\mathrm{N}, \mathrm{NW}\end{array}$ & $\begin{array}{l}\text { High from all } \\
\text { quarters }\end{array}$ & $\begin{array}{l}\text { Moderate mainly } \\
N, \mathrm{NW}\end{array}$ \\
\hline $\begin{array}{l}\text { Wave } \\
\text { exposure }\end{array}$ & $\begin{array}{l}\text { Moderate on west } \\
\text { and north shores. } \\
\text { Light on west } \\
\text { shores. }\end{array}$ & $\begin{array}{l}\text { High especially in } \\
\text { outer Bay. }\end{array}$ & $\begin{array}{l}\text { Light on all shores } \\
\text { if any. }\end{array}$ & High all round & Moderate \\
\hline $\begin{array}{l}\text { MARINE } \\
\text { FARMING } \\
\text { PROSPECTS }\end{array}$ & $\begin{array}{l}\text { Laverique Bay good } \\
\text { Saratoga Bay medium } \\
\text { Tuhitarata and } \\
\text { western bays good } \\
\text { with adequate } \\
\text { moorings. }\end{array}$ & $\begin{array}{l}\text { Minimal overall. } \\
\text { Possibility of spat } \\
\text { rafts in Waimaru } \\
\text { and Waterfall Bays. }\end{array}$ & $\begin{array}{l}\text { Very good all round } \\
\text { especially Elie and } \\
\text { Hopai Bays. Wet } \\
\text { Inlet subject to } \\
\text { wide fluctuations. }\end{array}$ & $\begin{array}{c}\text { No } \\
\text { possibilities }\end{array}$ & $\begin{array}{l}\text { Good } \\
\text { overall }\end{array}$ \\
\hline
\end{tabular}

* These figures were arrived at by adding annual rainfall over sea surface area to $60 \%$ of rainfall over 1 and catchment area. The percentage was recommended by Mr Thompson, Chief Engineer, Marlborough Catchment Board. 
on the eastern side make the slope more gradual. A depression is present outside Laverique Bay and another off Hikurangi Peninsula, probably as a result of tidal scouring. Tidal circulation is known to be counterclockwise on the flood tide but simple and linear on the ebb.

For the marine farmer the advantages of this region are its large water volume, good circulation, and lack of freshwater influence. The disadvantages are its degree of exposure especially to southerly winds, and its depth.

The Eastern Region (see Figure 2.3) has a small water surface area and volume bounded by a large catchment area with moderate rainfall. Heavy rain could lead to substantial reduction in salinity however, this is likely to be only temporary due to the flushing action of the tide which in this region flows straight in and out. The depth at the entrance is about $30 \mathrm{~m}$ rising gradually to an extensive mudflat at the head of the bay. The coastline lacks any real inlets and therefore little shelter is available anywhere within the region. Winds are funnelled by the surrounding hills and the region experiences the roughest seas in the Beatrix Basin.

A good water turnover is the one advantage of this region. Its disadvantages include the high degree of exposure to both wind and waves, as well as the lack of small bays or 
inlets for shelter.

The Southern Region (see Figure 2.3) Entrance to this region is by way of a narrow corridor formed by the western hills on one side and Hopai Peninsula and Ouokaha Island on the other. This corridor gives way to the three main bays and some smaller ones. Mean depth is about $25 \mathrm{~m}$ although Elie Bay and wet Inlet are considerably shallower in parts and both areas have mudflats at the head (Plate 2.4). The catchment area is extensive especially to the east and south and rainfall is higher than other parts of Beatrix Basin. The region is sheltered from virtually all directions except at the entrance where northerly and southerly winds could be strong at times.

The flood tide circulates counter-clockwise, but the ebb pattern is rather confused. Tidal movements are slow and since wind action on surface water is minimal, water turnover is expected to be low. This results in a reduction of salinity after heavy rain, especially in wet Inlet.

Advantages to the marine farmer are the high degree of shelter and the extent of suitable depth $(10 \mathrm{~m}-20 \mathrm{~m})$. The most serious disadvantage is the small water turnover and as a result of this, the effect of freshwater inflow.

The Central Region (see Figure 2.3) is a stretch of water open on all sides and exposed to a high degree of wind 
action. Situated just inside the entrance to the Basin and confluent with the other three regions, it is the area of highest degree of mixing as is shown by temperature and salinity records. This mixing is the result of tidal currents as well as wind generated surface water movement. Sea condition is most of the time too rough for any marine farming operations.

It can be said in conclusion that marine farming structures could be placed anywhere in the southern region and along the southeast aspect of the northern region. The excessive amount of exposure precludes these operations from the central and eastern regions. Other parts of the northern region could possibly be used for marine farming projects if allowance is made for the moderate exposure which this region is subjected to at times. Hydrological fluctuations are expected to be smaller in the northern region due to its more marked tidal circulation and therefore this region would probably be better than the southern region for intensive marine farming. 


\section{ACKNOWLEDGMENTS}

I would like to thank the Director of the N.Z. Meteorological Service and his staff for setting up the climatological station at Elie Bay and for making available past records to me. Special thanks go to Mr R. Halliday of Elie Bay for daily recordings, and Mr N.G. Robertson, Assistant Director Climatology, for advice and discussion of the manuscript.

My thanks are also due to the Director and staff of the N.Z. Oceanographic Institute and especially Dr R.A. Heath and Mr N.M. Ridgway, for the loan of various instruments and much needed advice; the Marlborough Harbour Board and Fisheries Management Division of the Ministry of Agriculture and Fisheries who assisted with the charter of aircraft for the dye experiments and Mr M. McGreevy of the Forest Research Institute who took some of the photographs.

Last but not least I would like to thank all the residents of the Marlborough Sounds, as well as visitors to the area who conscientiously supplied the details and mailed drift cards back to me. 
BECK, A.C. (1964) Geological Map of New Zealand Sheet 14 Marlborough Sounds. New Zealand Geological Survey.

BOWDEN, K.T. (1953) Note on wind drift in a channel in the presence of tidal currents. Proceedings of the Royal Society, London. 219A : 426-446

BRODIE, J.W. (1958) A note on tidal circulation in Port Nicholson, New Zealand. New Zealand Journal of Geology and Geophysics 1(4): 684-702

BROWN, N.I. \& HAMON, B.V. (1961) An inductive salinometer. Deep Sea Research $8(1): 65-75$

GARNER, D.M. \& RIDGWAY, N.M. (1955) A note on tidal circulation in Lyttelton Harbour. New Zealand Journal of Science and Technology Sec. B $37(1)$ : 4. 7-53

GRINDLEY, G.W. et al (1961) The geological map of New Zealand. New Zealand Geological Survey Bulletin n.s. 66

HEATH, R.A. (1973) Meteorological effects on the surface circulation and hydrology of Tasman Bay, New Zealand. New Zealand Journal Marine and Freshwater Research. $7(1,2)=111-123$ 
HEATH, R.A. (1974) Physical oceanographic observations in Marlborough Sounds. New Zealand Journal Marine and Freshwater Research 8(4): 691-708 HUGHES, P. (1955) A determination of the relation between wind and sea surface drift. Quarterly Journal of the Royal Meteorological Society 82: 494-502

NEW ZEALAND METEOROLOGICAL SERVICE (1973) Meteorological observations for 1973. N.Z. Meteorological Service Miscellaneous Publications 109

NEW ZEALAND METEOROLOGICAL SERVICE (1974) Rainfall observations for 1973. N.Z. Meteorological Service Miscellaneous Publications 110

OLSON, F.C.W. (1951) A plastic envolope substitute for drift bottles. Journal of Marine Research 10(2): 190-3

RIDGWAY, N.M. (1960) Surface water movements in Hawke Bay, New Zealand. New Zealand Journal of Geology and Geophysics 3(2): 253-261

SteVEnS, G.R. (1974) Rugged Landscape A.H. \& A.W. Reed, Wellington. 286pp. 
SECTION THREE

THE REPRODUCTIVE CYCLE OF MUSSELS AND THEIR SETTLEMENT AND SURVIVAL ON MATERIALS WITH COMMERCIAL POTENTIAL 
There are basically three ways of farming mussels. The Dutch method consists of taking seed mussels from dense beds in poor growing areas and relaying them on the seabed in areas of good growth (Lambert 1949, Havinga 1956, 1964, Korringa 1976). In France and Italy mussels which have settled on sticks in the higher tidal reaches are transferred subtidally for faster growth, then 'hardened' intertidally before harvesting (Field 1922, Audoin 1954, Fauvel 1954, Mason 1972). The Spanish mussel farmer acknowledged as the most successful (Mason, 1971), obtains seed from the shore or from settlement ropes suspended for that purpose from rafts. The seed is bound on to growing ropes by a netting band which lasts a few days long enough for the mussels to attach to the ropes (Waugh 1966, Andreu 1968a, 1973, Anon 1968, Losada et al 1971, Figueras 1976). These ropes are also suspended from rafts. The suspension method can also be used with mussel seed contained within a plastic mesh cylinder tied at intervals, with or without a strengthening rope running through the centre (Bohle 1970, Mandelli \& Acuna 1975, Moller \& Giordano 1975). Another alternative is to place the juvenile mussels in perforated plastic cones attached to the ropes at $30 \mathrm{~cm}$ intervals (MacFarlane, 1971).

All the above methods involve handling and this provides the opportunity for controlling the overall density on 
the rope, obtaining an even distribution along its: entire length, and removing competitors such as barnacles and ascidians (Bardach et al., 1972). Seed mussels from natural settlements are available in quantity in New Zealand (Hickman, 1975). Handling however, means labour costs and these were foreseen as a major problem for the mussel farming industry in New Zealand at the outset (Campbel1 1971, Waugh 1971). This means that the New Zealand mussel farmer, in trying to cut down costs, relies on natural settlement on the same ropes he will eventually harvest from. Natural settlement must provide the mussel farmer with the right density, even distribution along the rope, and a low incidence of competing organisms and nuisance growths.

Spat collecting is rarely considered a problem in the operation of mussel farms in countries other than New Zealand where it has become one of the main constraints for the industry (Anon 1975, Hickman 1975). Spatfall is erratic, often unevenly distributed on the ropes, and while the ropes used are undoubtedly attractive, they are non-specific and do not exclude competitors (Anon, 1974a). A further drawback of these ropes is that they require 'seasoning' before mussel larvae will settle on them. Oils used in manufacture must leach out (Lutz, 1974) and the ropes must obtain a film of bacteria, diatoms and other epibionts without which they are not suitable for mussels (Graham \& Gay 1945, Bayne 1964a, 1965 Board \& Collins 1965, Kiseleva 1966, Mason 1969). This 
means that while the ropes have to be immersed in water for some time before they will attract mussels, they are liable to fouling if they are immersed too long before spatfall (Wilson \& Hodgkin 1967, Ryther 1968, Pike 1971a, Maclean 1972). The immersion of mussel ropes currently employed by the industry in New Zealand therefore requires careful timing. This can only be based on accurate prediction of spatfall.

Timing of collector immersion is also a problem for the oyster (Crassostrea glomerata Gould) farmer in New Zealand who, like his mussel counterpart, relies on natural spatfall (Greenway 1969a, Curtin 1971a, Anon 1974b). In spite of the fact that much information exists on oyster settlement, there are years when there is little or no settlement even in the best catching areas ( Curtin, 1971a). The Ministry of Agriculture and Fisheries (formerly the Marine Department) maintains a spatfall forecasting service for oyster farmers (see Greenway 1969a, 1971, Curtin 1971b, 1971c, 1974). This is based on monitoring spatfall and advising farmers when an increase in oyster spat is observed to coincide with a decrease in bamacle (the chief competitor) settlement (Greenway, 1969a). The Fishing Industry Board has been aiming to provide a similar service for the mussel farmers in the Marlborough Sounds (Anon, 1975). They have used the density of planktonic larvae (see Needler 1940, Martinez 1967, Hrs-Brenko 1972, 1973) and settlement monitoring (see Davies, 1974) as indicators 
of the start of the settlement season. This has had only limited success. Other indicators of spatfall could be the reproductive state of the adult mussel population in the area (Chipperfield 1953, Flaws 1975) and some hydrological conditions known to influence settlement (Young 1945, Korringa 1947, Manning \& Whaley 1954, Bayne 1965, Rojas 1969).

The present study examined the reliability of these indicators in forecasting spatfall with sufficient accuracy to be of value to mussel farmers. Since there were doubts regarding the degree of accuracy possible in spatfall forecasting, it was thought desirable to obviate the need for such accuracy. This could be achieved by employing some other settlement material unattractive to competitors (while still attractive to mussels) and which does not require seasoning.

As a first step this study set about determining the requirements and settlement behaviour of both mussels and their competitors. Once the requirements for New Zealand mussels were known the study concentrated on a search for a new settlement material. This material had to be attractive to mussel larvae while repulsive to the important competitors, durable in seawater, easy to handle, cheap to produce, requiring little or no seasoning, and requiring no transfers between settlement and harvest. 
A wide variety of materials have been used for mussel farming. The original Spanish ropes were made of esparto grass (Andreu, 1968b). Manila (Lutz, 1974) and sisal have both been employed (Maclean, 1972). Bamboo has been used in the Philippines and Venezuela (Martinez 1971, Tortel1 \& Yap 1976). Coconut husk also has proved an excellent collector in the former country (Torte11, 1976) and when spun into coir rope it is probably the most successful natural collector (Mason 1969, Dare \& Davies 1975). Chicken wire mesh (Loosanoff, 1946), cement pieces laced in the lay of the rope (Nikolic \& Stojnic, 1963) and foam plastic pieces (Ivanov, 1971) are among the synthetic materials that have been advocated. Most of these and other materials were tested in the course of this study.

Although perna canaliculus is the main commercial species in New Zealand and forms the basis of the present study, data on Mytilus edulis aoteanus were also recorded whenever possible. Perna canaliculus and Mytilus edulis aoteanus will be refered to as Perna and Mytilus respectively throughout the rest of this study.

\subsubsection{Spatfall Forecasting}

This study recorded the reproductive cycle in perna 
and Mytilus and noted especially the presence of mussels in ripe condition and those that were either partially or fully spawned.

A random sample of ten mussels each of Perna and Mytilus was collected from the native population at Elie Bay

(Fig. 3.1) approximately monthly between April 1973 and April 1974. Mean length for Perna was $12 \mathrm{~cm}$ and $9 \mathrm{~cm}$ for Mytilus. The mussels were opened immediately to avoid the possibility of spontaneous spawning (Tortell, 1974) and the mesosoma (see Flaws, 1975) was fixed in Bouin's Fixative. After embedding in wax, sections of $8 \mu \mathrm{m}$ were cut and counterstained with Delafield's haematoxylin and eosin. The sections were examined microscopically and assigned to one of seven stages making up the three broad phases of the reproductive cycle, namely, gametogenesis, spawning, and recovery.

Table 3.1 was constructed from observations of the reproductive cycle in both species of mussels during this study (observations recorded in 3.3.1) and after reference to published classifications of the breeding cycle in the Mytilidae (Chipperfield 1953, Lubet 1957, Heinonen 1961, Wisely 1964, Wilson \& Hodgkin 1967, Lunetta 1969). The classification by Flaws (1975) for mussels in the Marlborough Sounds was not available during the study.

Plankton samples for the present study were collected every 3-4 days between June 1973 and April 1974 from 
BEATRIX BASIN, MARLBOROUGH SOUNDS

Biological Stations 


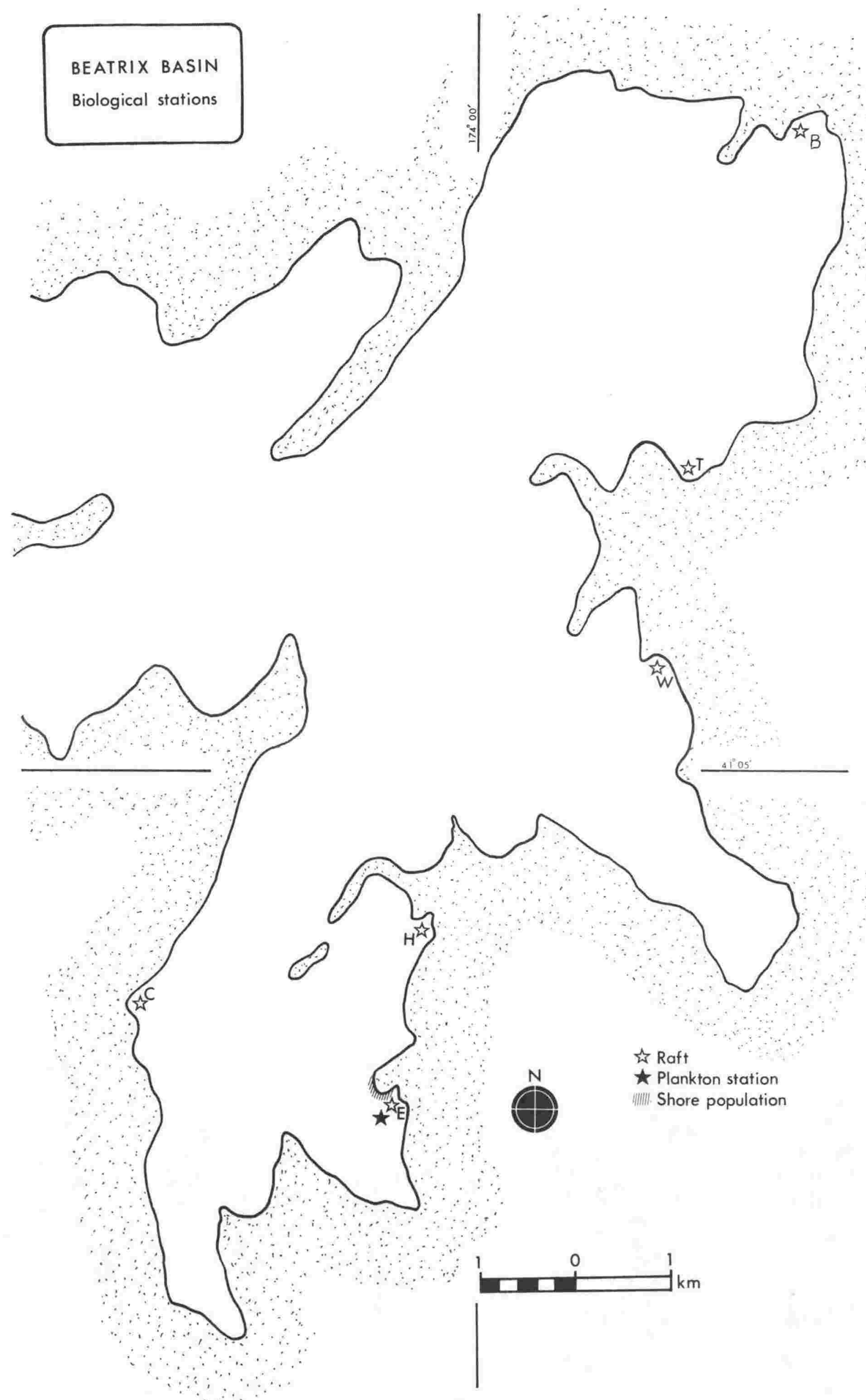


Stage I Onset of Gametogenesis

Appearance of isolated follicles and sexes distinguishable. Spermatogonia in males but no spermatozoa. Oocytes in the females are small and few in number.

\section{Stage II Advanced Gametogenesis}

Further development of follicles which fill up more with gametes which are still immature. Follicles are more numerous and connective tissue is reduced further.

\section{Stage III Ripe}

Follicles packed with gametes and connective tissue virtually absent. Individuals will spawn if stimulated and gametes are mature. In males the sperm are aligned with tails towards lumen forming radial lamellae. In females the ova are polygonal due to tight packing in the follicles.

Stage IV Partially spawned

Follicles partially vacated but new gametes are being formed. Spermatogenetic tissue in the male is still present as a thick dark-staining $b$ and on the periphery of the follicles. Ova in the females are more spherical due to release of pressure.

\section{Stage $V \quad$ Final Spawning}

Similar in appearance to Stage IV but containing few or no new gametes. Amoebocytes present in increasing numbers. Spermatogenetic tissue in males reduced to a thin band or completely absent. No new oocytes budding off the follicular wall in females.

\section{Stage VI Spent}

Few follicles left and most empty of gametes but full of

amoebocytes. Any remaining ova undergoing autolysis and
follicular walls are breaking down. Connective tissue pro-
liferating and replacing follicles.
St $\begin{aligned} & \text { No trace of sexuality in gonads. Follicles and ducts } \\ & \text { obliterated by proliferation of connective tissue containing } \\ & \text { quantities of food reserves. }\end{aligned}$

(Adapted from Chipperfield 1953, Lubet 1957, Heinonen 1961, Wisely 1964, Wilson \& Hodgkin 1967, Lunetta 1969, and observations during the present study.) 
Elie Bay (Fig. 3.1). Sampling was done on the rising tide whenever possible, using a WP-2 free fall net of $100 \mu \mathrm{m}$ mesh size as described by Booth (1972). The net was allowed to fall through $5 \mathrm{~m}$ (mean depth at station $6 \mathrm{~m}$ ) before throttling, thus sampling ca 500 litres. Samples were preserved in $4 \%$ bufferred formalin in seawater. On five occasions samples were taken on the same day from Waimaru and Beatrix Bays and compared with ones from the regular station in Elie Bay.

The larvae were identified by the characteristic shape and proportions of the veliconch and prodissoconch shells according to descriptions by Rees (1950), Miyazaki (1962), Martinez (1967), Chanley (1970) and Booth (1972).

The presence of spawning adult mussels, planktonic larval density and climatological and hydrological records (see Section Two) were related to subsequent settlement of spat to determine their possible use in accurate spatfall prediction.

\subsubsection{Settlement and Settlement Materials}

A preliminary experiment was conducted to determine which of the six materials shown in Plate 3.1 and described below was the most suitable for mussel farming. i) White polypropylene fibrillated film. This material 
PLATE 3.1 Six materials tested as crosspieces for their suitability for mussel farming. From left : white film, coir twine, foam plastic, sisal twine, black film and yellow filaments.

PLATE 3.2 Samples of black polypropylene film, coir rope and black polypropylene film rope.

PLATE 3.3 Metal frame used to suspend mussel collectors. Mussels settled on the frame above the collectors appear to have migrated from the latter since none are found on the rest of the frame. 

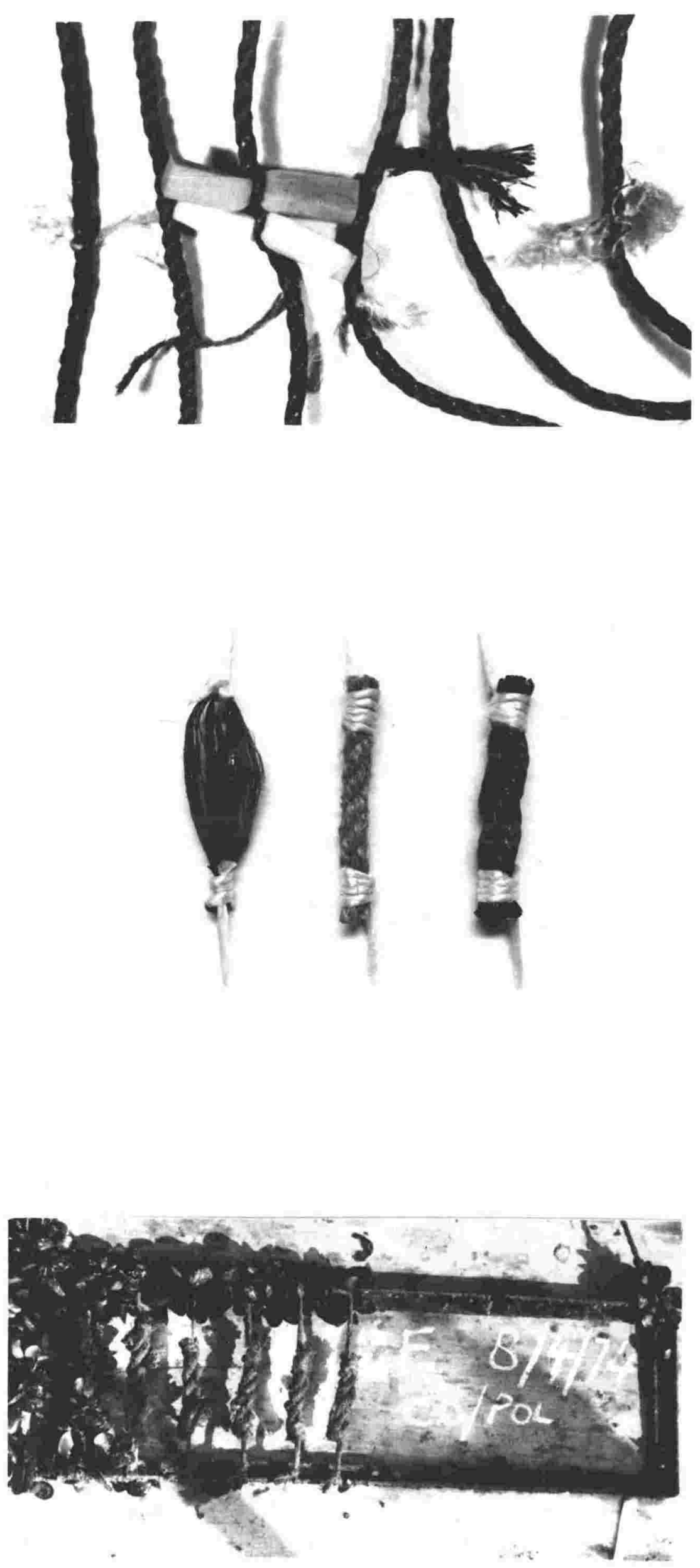
(hereafter refered to as the white film) is extruded from undyed polypropylene chips as a flat sheet about $10 \mathrm{~cm}$ wide and $50 \mu \mathrm{m}$ in thickness which is fibrillated by a series of blades to produce a syncytium of fibres of varying cross-sections. It is then twisted to produce a general purpose twine normally used for packaging.

ii) Coir twine (ca $5 \mathrm{~mm}$ diameter) is spun from coconut fibres. It was obtained for this study by unravelling coir rope. The short staple of coconut fibres and their differing cross-sections give spun coir a shaggy and uneven surface.

iii) Foam plastic pieces used for this study were of the soft foam type with cells about $1.0 \mathrm{~mm}$ across. The pieces were cut into strips of $20 \mathrm{~mm}$ by $20 \mathrm{~mm}$ crosssection and $120 \mathrm{~mm}$ in length.

iv) Sisal twine is manufactured from agave leaf fibres. Unlike the coconut husk sisal fibres were much more uniform in cross-section being ca $250 \mu \mathrm{m}$ in diameter. The sisal twine was spun in a looser lay than the coir twine.

v) Black polypropylene fibrillated film was identical to the white film mentioned above apart from the fact that it was dyed with carbon black during manufacture. It is hereafter refered to as the black film. vi) Yellow polypropylene filaments are imported as a yarn and spun into ropes. The filaments are identical in cross-section (ca $20 \mu \mathrm{m}$ ) and each filament ran the 
whole length of the rope. Tight lay ropes were unravelled for this experiment.

Crosspieces of each material ( $15 \mathrm{~cm}$ long) were inserted in the lay of a $3.5 \mathrm{~m}$ long standard orange polypropylene rope at $20 \mathrm{~cm}$ intervals. A new set of ropes was immersed approximately monthly at Elie Bay starting in october 1972 until september 1973. Records were kept of mussel settlement and survival, fouling, silting, strength, and durability in seawater. The materials were graded on a five-point scale according to their performance for each of the above criteria.

Coir and the black film showed the most promise after the above preliminary experiments and were subjected to a more thorough examination. Duplicate samples $(10 \mathrm{~cm})$ of coir rope, black film, and a rope manufactured out of the black film (see Plate 3.2) were placed on separate frames (as in Plate 3.3) suspended within $75 \mathrm{~cm}$ of the surface, on each of the following dates :

1973 September 27

October 27

November 23

December 3, 21

1974 January 4, 14, 25, 30

February $4,16,23,27$

March $9,22,26$

On each visit, one of the two samples put out on the preceeding occasion, was recovered and a new pair 
installed. A record of settlement between visits as well as a record of survival and subsequent recruitment on collectors of different ages, was thus obtained. All long term samples were finally retrieved on 8 April 1974. The rope samples were fixed in 10\% formalin and all adhering organisms removed with a brush under water, identified, measured and counted.

The ropes were graded for their ability to attract and retain mussel larvae, their resistance to fouling, and their strength and durability in seawater. The experiment was based on the raft at Elie Bay with replicates at Waimaru and Beatrix Bays (Fig. 3.1).

In December 1973 sets of five joined frames (as in Plate 3.3) with a total of 60 collectors, were suspended vertically from the rafts at Elie, Waimaru and Beatrix Bays, to determine if settlement density of mussels altered with depth in the upper $3.5 \mathrm{~m}$ of the water column. It was decided to limit the study to the upper $3.5 \mathrm{~m}$ of water since this is the maximum length of mussel rope that a single person can handle easily at harvest time (Jenkins, Fishing Industry Board, pers. comm.). The collectors were thus oriented horizontally to avoid migration after settlement, and consisted of pieces of rubberised hair packing commercially known as "Hairlok" and used in the upholstery trade for padding (Plate 3.4 ). This material was known to be a good collector of mussel spat (Davies, 1974) but 
RUBBERISED HAIR PACKING

A Close up of the material used in monitoring settlement according to depth and which was very successful in attracting mussel larvae. About natural size.

B Low power S.E.M. showing the variety of filaments and ramifications available for mussel settlement.

C High power S.E.M. of a latex cement 'island' which is thought to be attractive for mussel larvae. 

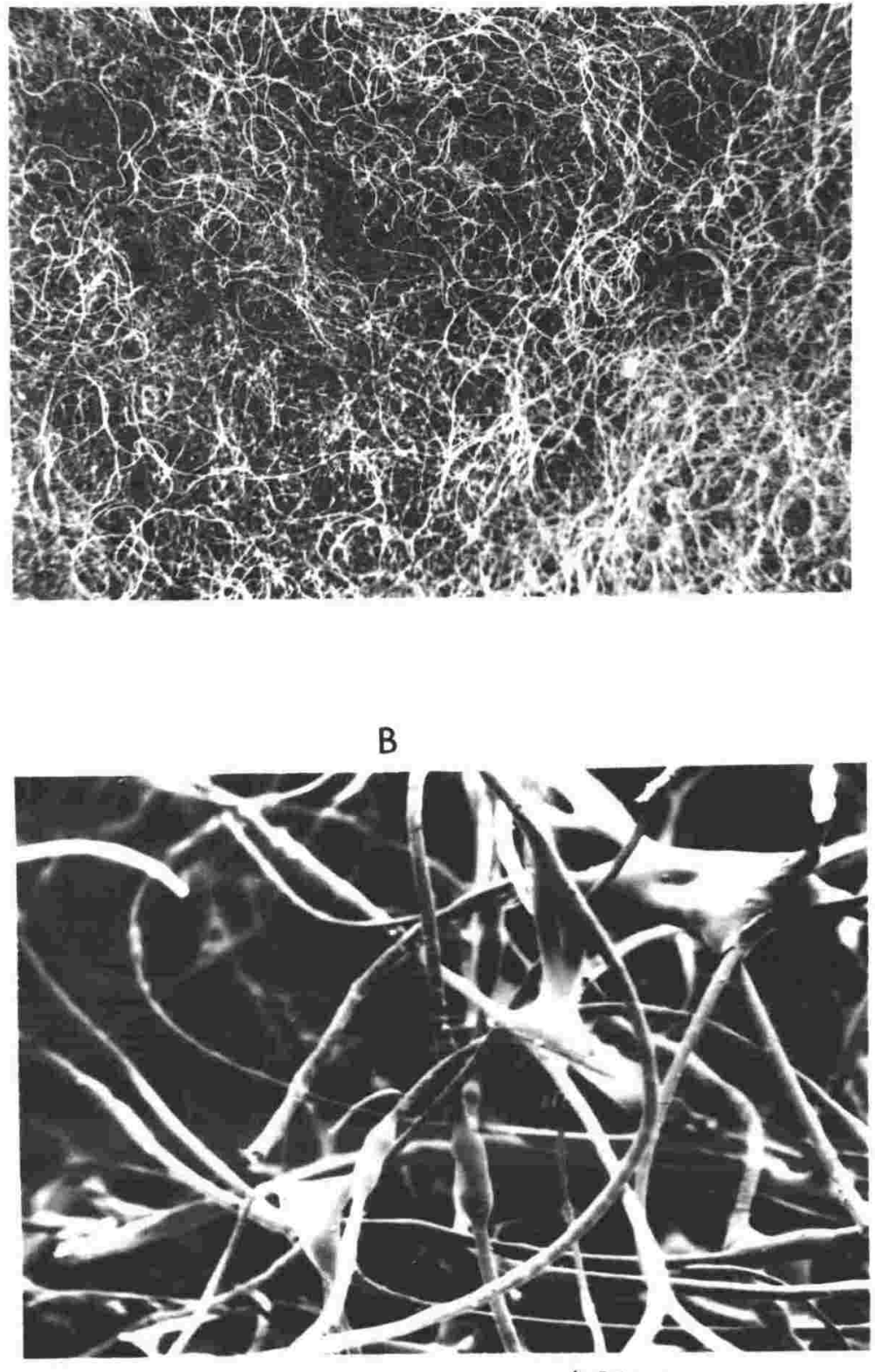

$400 \mu \mathrm{m}$

C

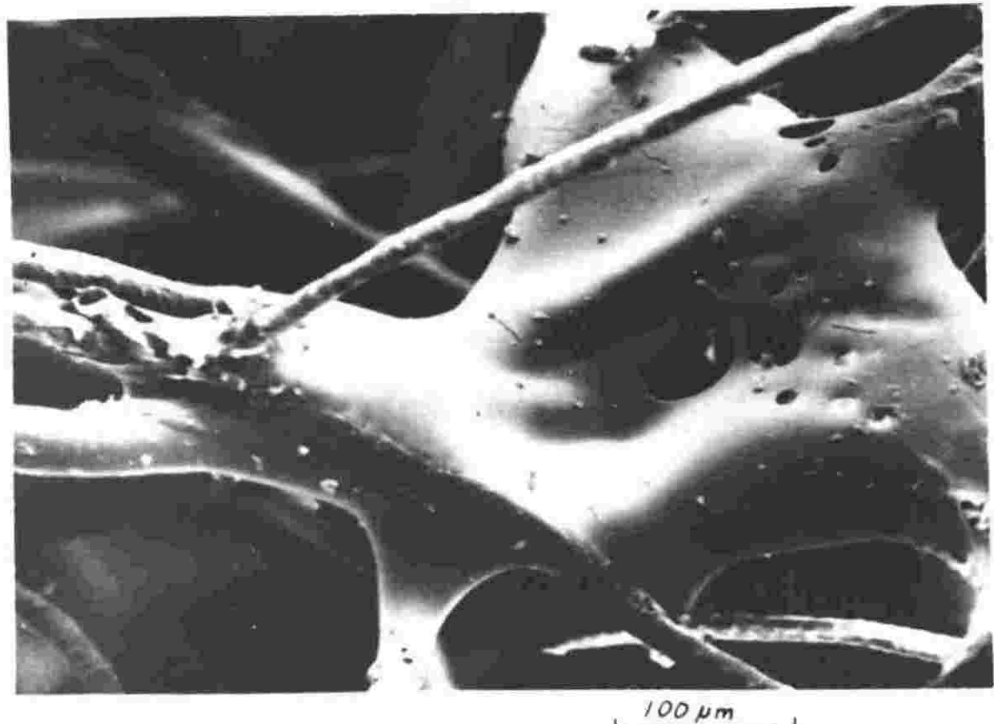


unfortunately it became available only late in the programme. At the end of March 1974 the frames were retrieved and the collectors fixed in 10\% buffered formalin. Groups of six collectors representing ca $35 \mathrm{~cm}$ of the water column were analysed together. Patterns of mussel settlement against depth were obtained from Elie, Waimaru and Beatrix Bays for both Perna and Mytilus.

Perna from Elie Bay were further divided into size classes and collectors from the same station were examined for fouling organisms. Amphipods were counted after subsampling according to Elliott (1973) $\left(\mathrm{P}=0.65\right.$ when $\mathrm{X}^{2}=2.14$ with $4^{\circ}$ of freedom).

The degree of relationship between settlement peaks and presence of spawners, concentration of planktonic larvae, and a number of environmental factors was determined.

The most common organisms encountered in this study and means of identification are listed below :

\section{Platyhelminthes}

Polyclad worm tentatively identified as stylochus sp. from Morton \& Miller (1973).

Annelida, Polychaetae

Platynereis. sp. Nereis falcaria (Willey) 
Perinereis $\mathrm{sp}$.

Ophiodromus anqustifrons (Grube)

Lepidonotus sp.

(Identified by G.B. Read, Victoria University

Marine Laboratory. Hereafter refered to collectively as polychaetes)

Mollusca, Bivalvia

Perna canaliculus (Gmelin)

Mytilus edulis aoteanus (Powell)

Ryenella impacta (Herman)

Hiatella australis (Lamarck)

(Identified from Powell (1961). Hereafter refered

to as Perna, Mytilus, Ryenella and Hiatella

respectively)

Arthropoda, Crustacea

Jassa falcata (Montagu)

Corophium volutator (Latreille)

Capre1la sp.

(Identified from Pike (1971b) and refered to in

this study as amphipods)

Elminius modestus (Darwin)

(Identified from Morton \& Miller-(1973) and called barnacles in this study)

Pinnotheres novaezelandiae Filhol

Halicarcinus cookii Filhol

(Identified from Melrose (1975), confirmed by

R.G. Wear, Victoria university) 
Chordata, Ascidacea

Colonial tunicates tentatively identified as belonging to the genus Didemnum.

Chordata, Pisces

Chrysophrys auratus (Forster, N. Block \& Schneider) Navodon scaber (Forster, N. Block \& Schneider)

Stigmatophora longirostris Hutton

(Identified from Heath \& Moreland

(1967) and confirmed by Moreland, National Museum, Wellington)

Chordata, Aves

Larus dominicanus (Lichtenstein)

(Identified from Ornithological Society of New Zealand (1970) )

3.3

RESULTS AND DISCUSSION

Biological records are summarised in Figure 3.2. Settlement commenced in November, but planktonic larvae were first noticed in late December. Settlement between November and December took place before any spawned mussels had been detected. The concentration of planktonic larvae oscillated considerably without any reflection in settlement and a rise in the number of spawned mussels in February failed to produce a comparable rise in pelagic larval density. On the other 
THE RELATIONSHIP BETWEEN BIOLOGICAI AND PHYSICAL PHENOMENA BETWEEN OCTOBER 1973 AND APRIL 1974

The middle section of the diagram records spawning, occurrence of larvae and settlement of Perna canaliculus. Above are wind force (which has a direct influence on the state of the sea), salinity, water temperature and phases of the moon. Climatological data are shown in the lower sections with air temperature extremes, cloud cover (both of which may act upon intertidal mussel populations) and rainfall. 


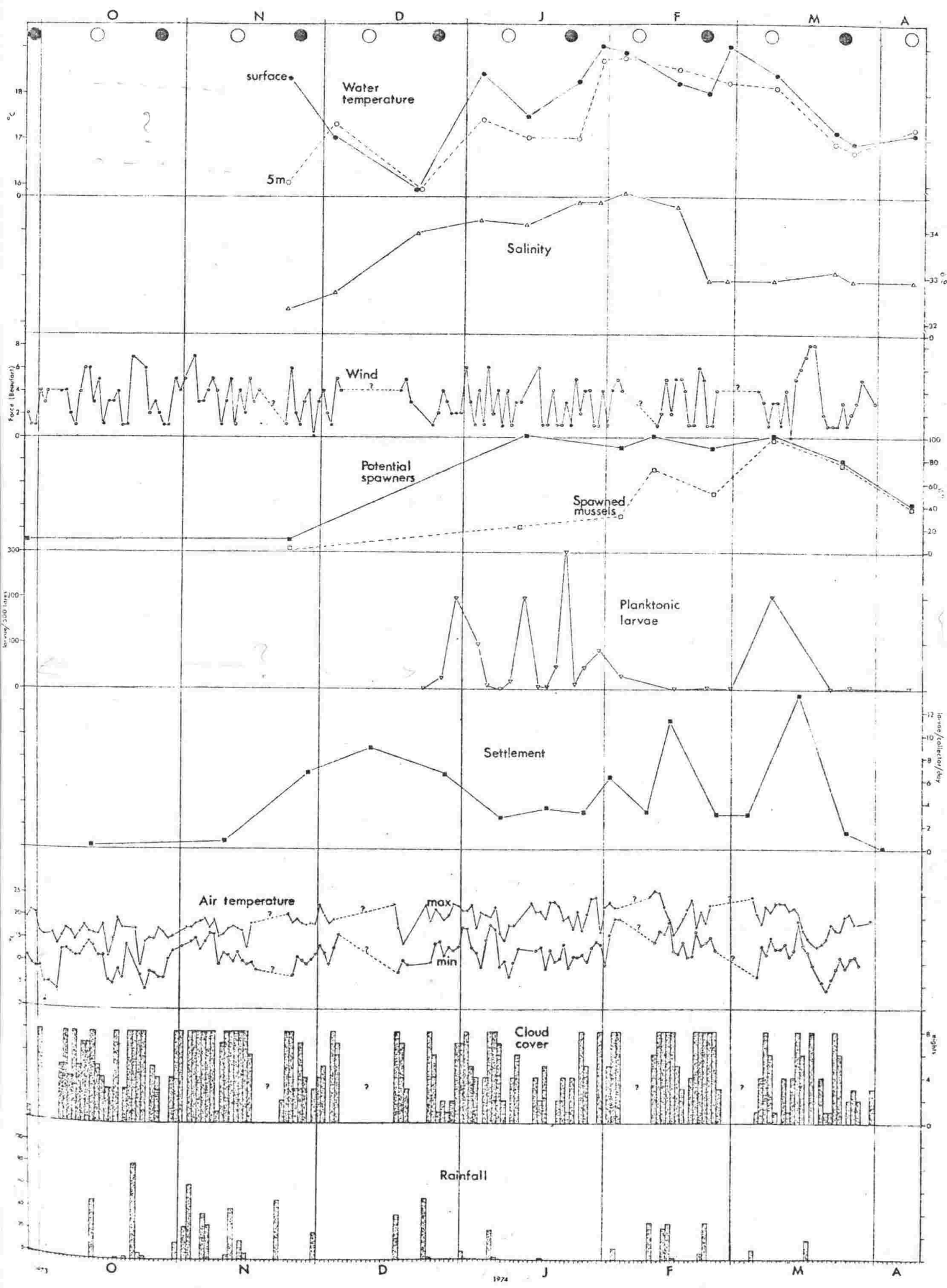


hand, maximum spawning activity in March preceded peaks in the number of planktonic larvae and in settlement density as expected. The expected. sequence of events appears to occur only at times of maximum activity.

The discrepancies listed above can be attributed to three main causes : i) irregularities in the breeding cycle resulting in intermittent spawning, ii) variability in the duration of the pelagic phase, uneven distribution of the larvae, and their rate of survival, iii) the influence of predation, competition and behaviour on spat yields from collectors. A complex of physical variables in the environment is also known to influence, if not control the above biological events.

\subsubsection{Reproductive Cycle}

The sexes are separate in Perna. Out of 150 mussels examined, $44.7 \%$ were male, 53.3\% were female, there were no hermaphrodites and $2.0 \%$ were of indeterminate sex. The latter group included a mussel rendered asexual by the sporocyst stage of the parasite Tergestia agnostomi (Manter) previously known as Cercaria haswelli Dollfus (see Jones, 1975a). Plate $3.6 \mathrm{~h}$ shows the infected gonad.

Mytilus also is dioecius. However, one mussel of the 
138 examined was hermaphroditic (see Plate 3.8h). There were $41.3 \%$ male mussels, $54.3 \%$ female, and $3.6 \%$ in the neuter stage whose sex could not be determined.

The reproductive cycles in Perna and Mytilus are morphologically similar (see Flaws, 1975) but temporally different. Three broad phases of the breeding cycle were recognised, namely gametogenesis, spawning and recovery. These were further subdivided into seven stages (see plates 3.5 to 3.8 ).

Gametogenesis was divided into two stages. Early gametogenesis (Stage I) was characterised by the appearance of small islands of ovarian or testicular. follicles in the mantle or mesosomal tissue, usually devoid of any gametes. The male follicles contained dark-staining spermatogonia and spermatids, while budding oocytes were found on the walls of the female follicles. Gametogenesis proceded to Stage II when the proliferating follicles contained immature gametes. The extent of the interfollicular tissue was then reduced to about $50 \%$ of the total gonad volume.

Mussels then entered the ripe or spawning phase divisible into three stages. Stage III gonads had very small amounts of connective tissue and the follicles were packed with ripe gametes. In the female the ripe 


\section{PERNA CANALICULUS - MALE REPRODUCTIVE CYCIE}
a) Stage I - onset of gametogenesis
b) Stage II - advanced gametogenesis
c) Stage III - ripe gonad
d) Stage IV - partially spawned gonad
e) Stage V - final spawning stage
f) Stage VI - spent gonad 


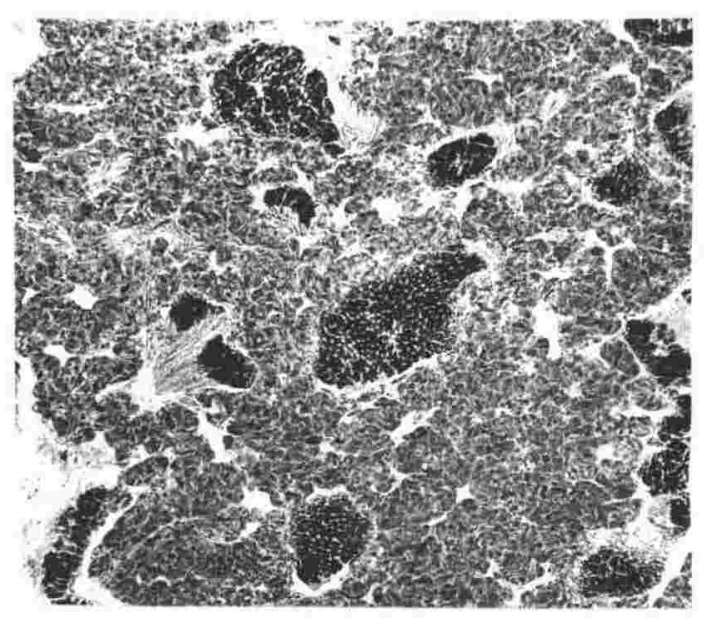

a

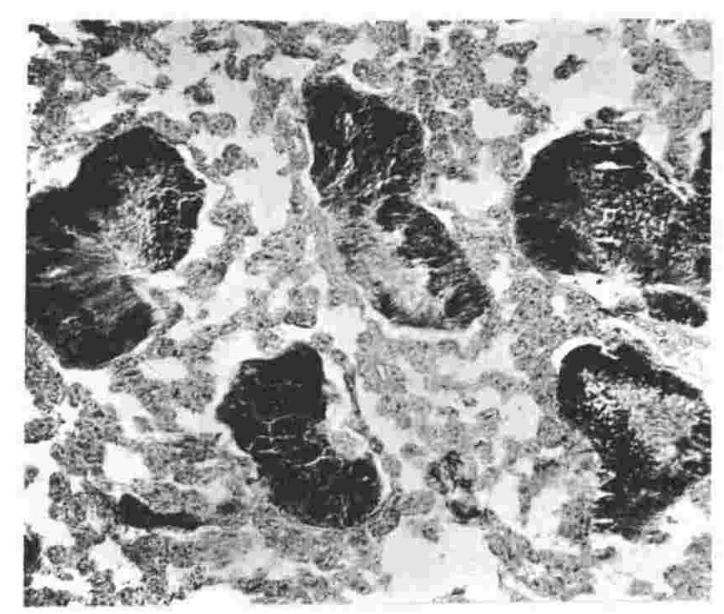

b

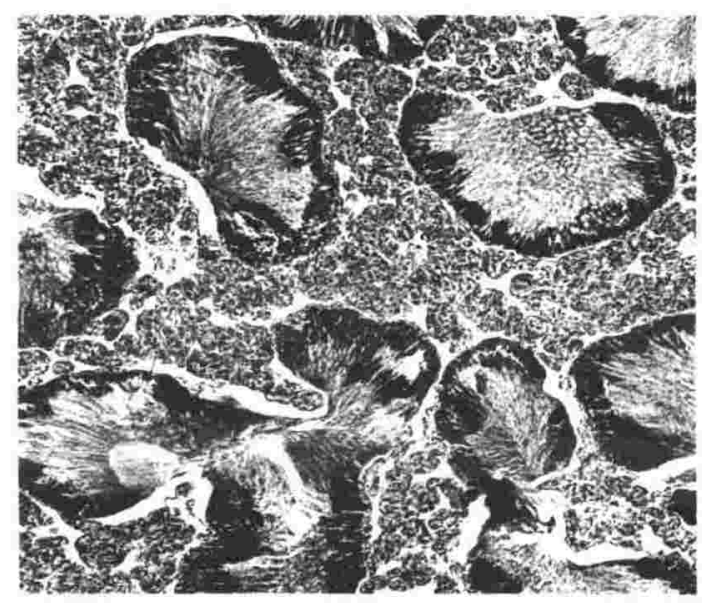

C

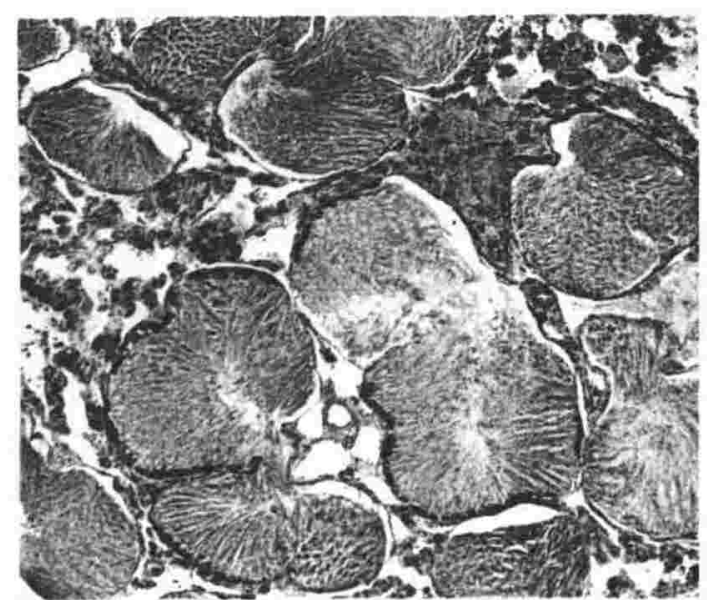

e

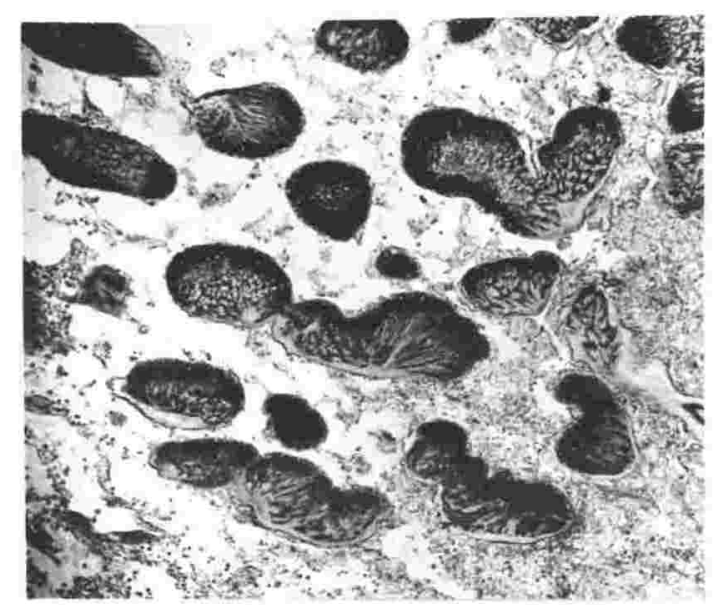

d

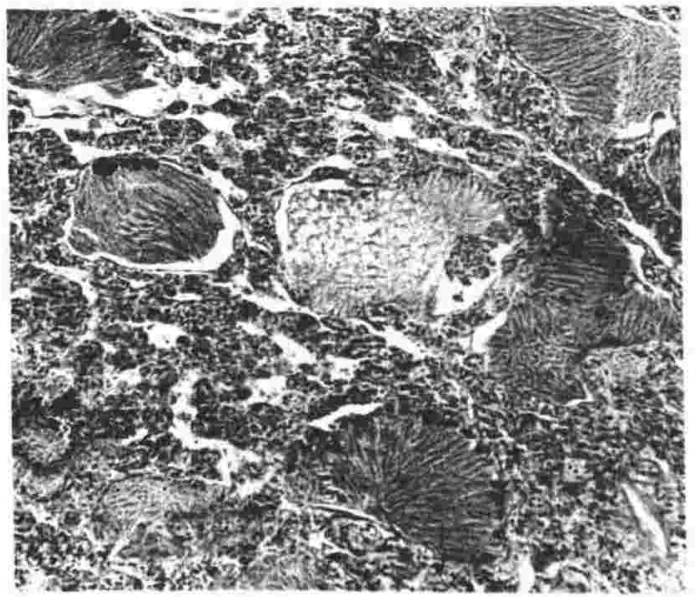
$f$ 


\section{PERNA CANALICULUS - FEMALE REPRODUCTIVE CYCLE}
a) Stage VII - neuter or resting stage
b) Stage I - onset of gametogenesis
c) Stage II - advanced gametogenesis
d) Stage III - ripe gonad
e) Stage IV - partially spawned gonad
f) Stage $V$ - final spawning stage

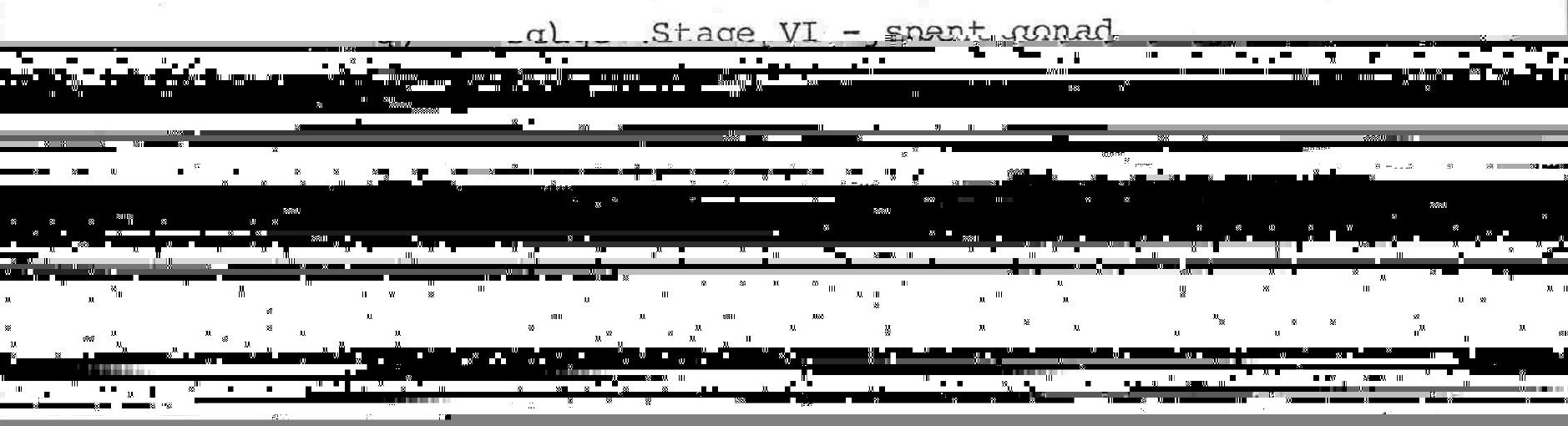




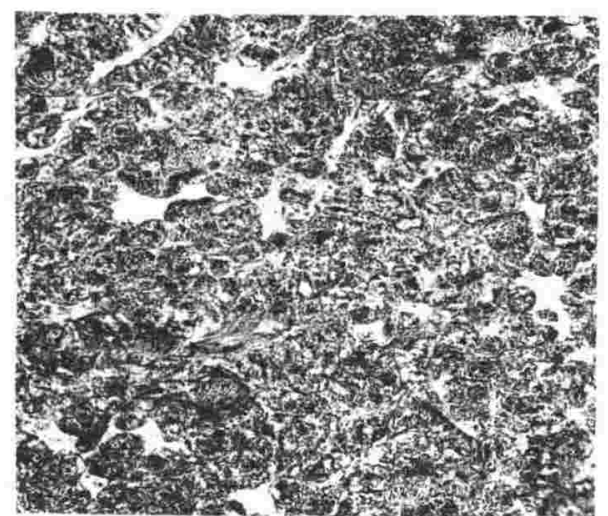

a
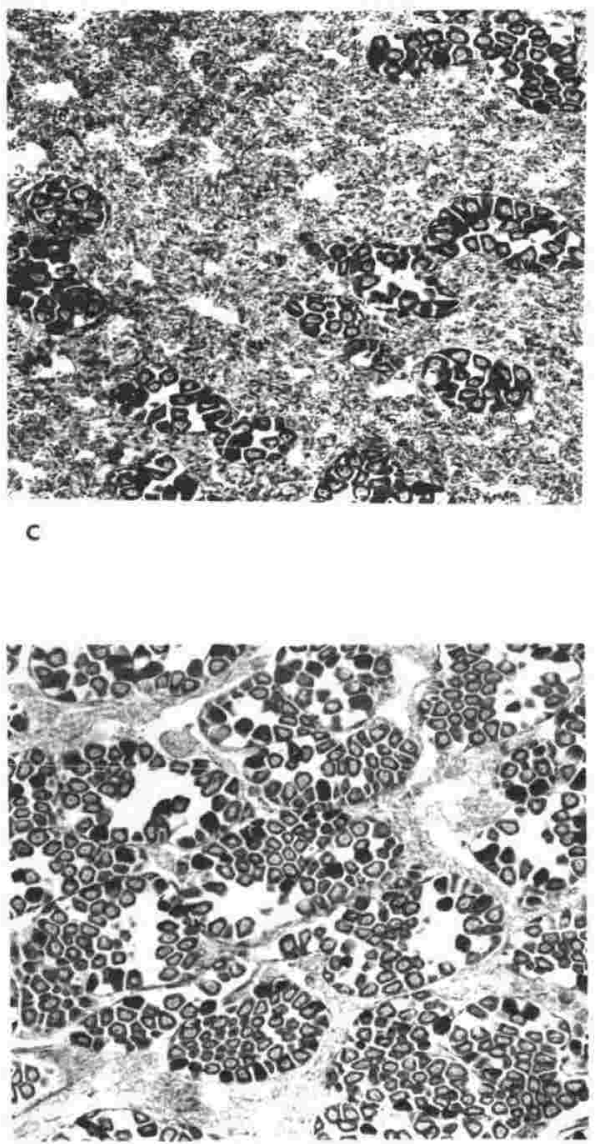

e

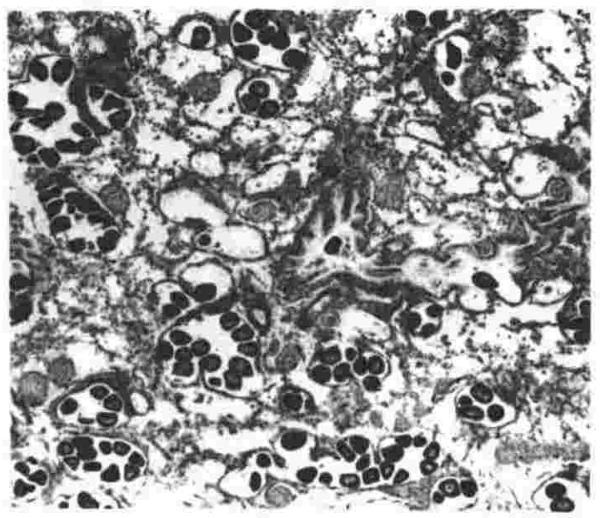

g

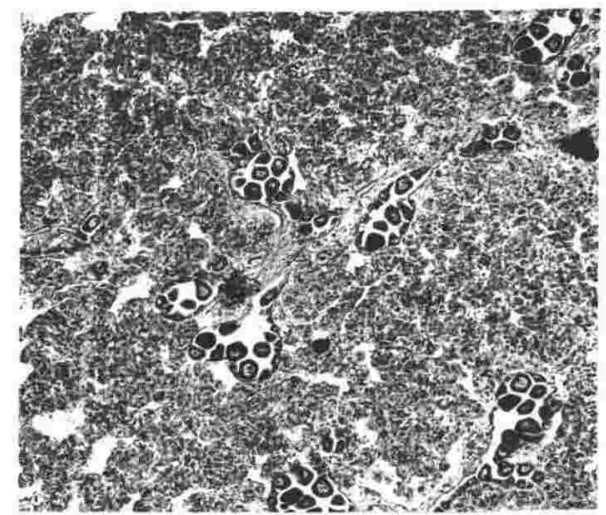

b

Decto.; T.

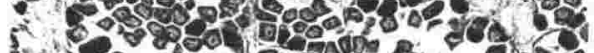

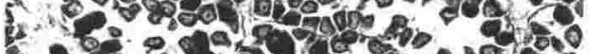

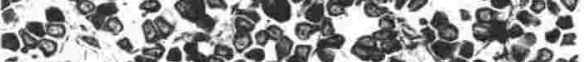

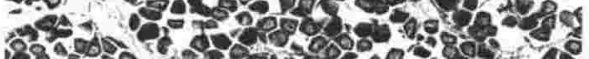

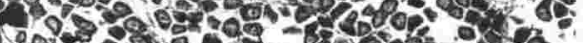

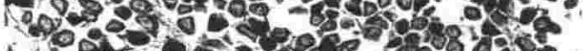
¿Po 38. 0 -

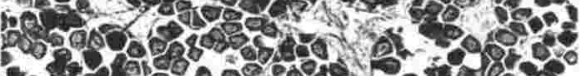

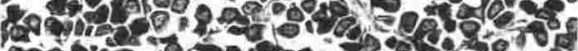
nstist d

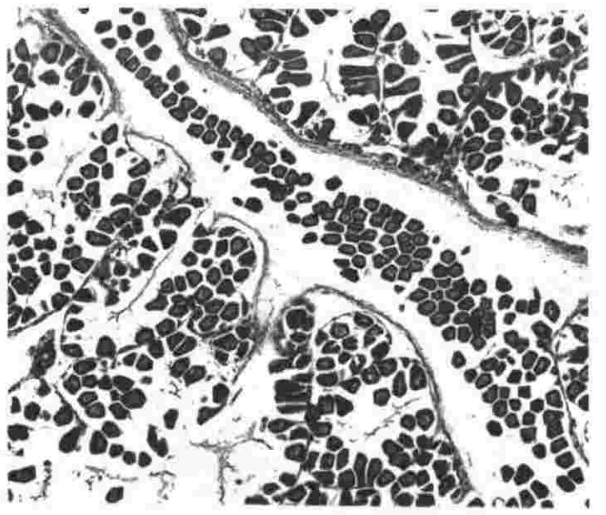
f

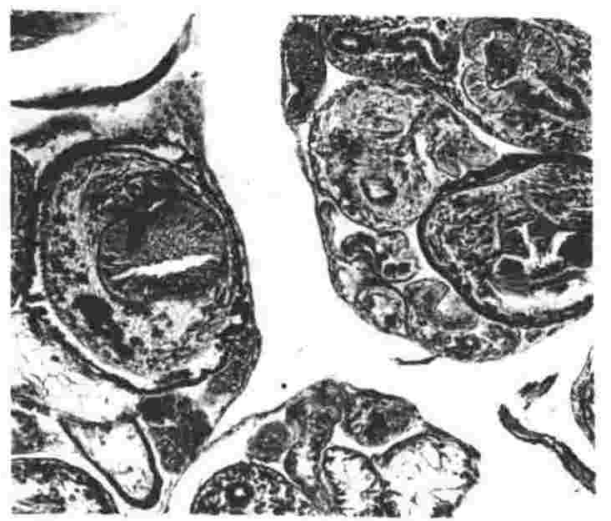

h 
MYTILUS EDULIS AOTEANUS - MALE REPRODUCTIVE CYCLE
a) Stage VII - neuter or resting stage
b) Stage I - onset of gametogenesis
c) Stage II - advanced gametogenesis
d) Stage III - ripe gonad
e) Stage IV - partially spawned gonad (?)
f) Stage $V$ - final spawning stage
g) Stage VI - spent gonad 


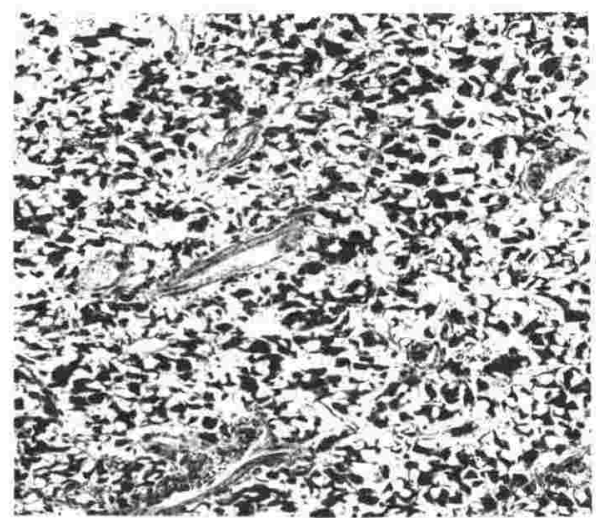

a

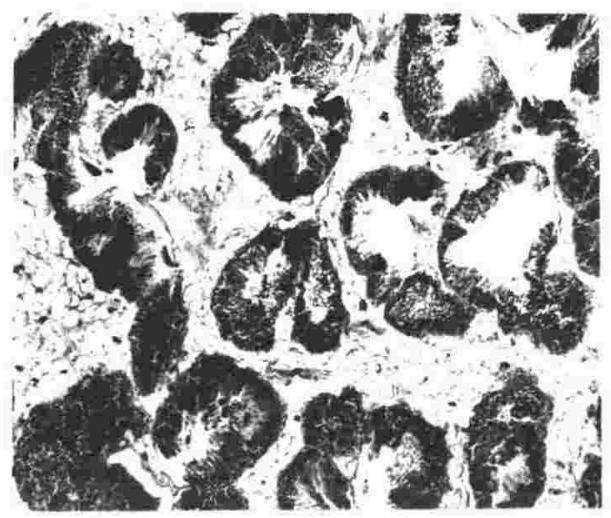

c

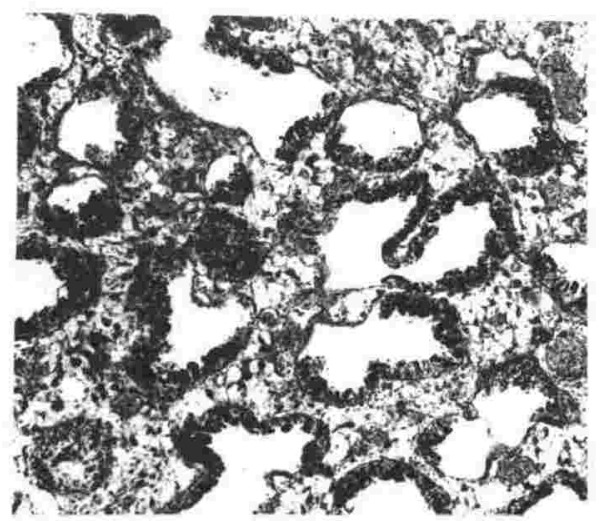

e

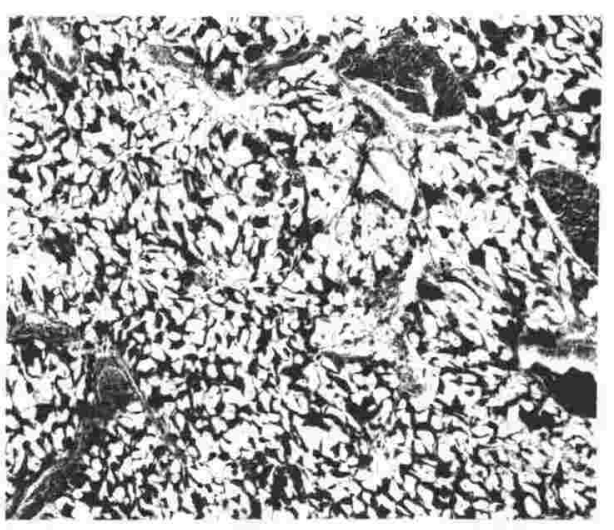

b

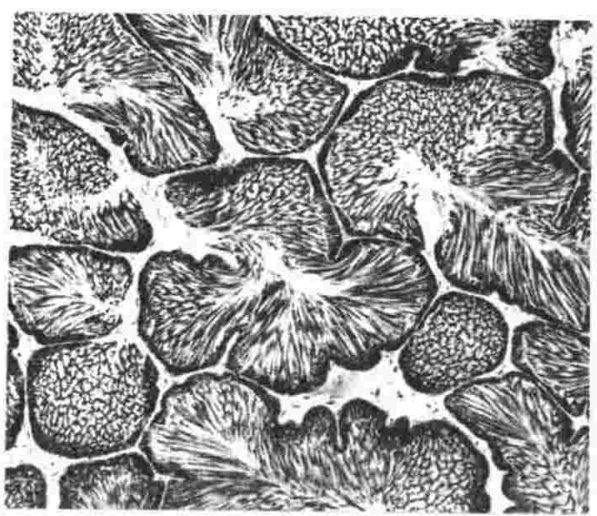

d

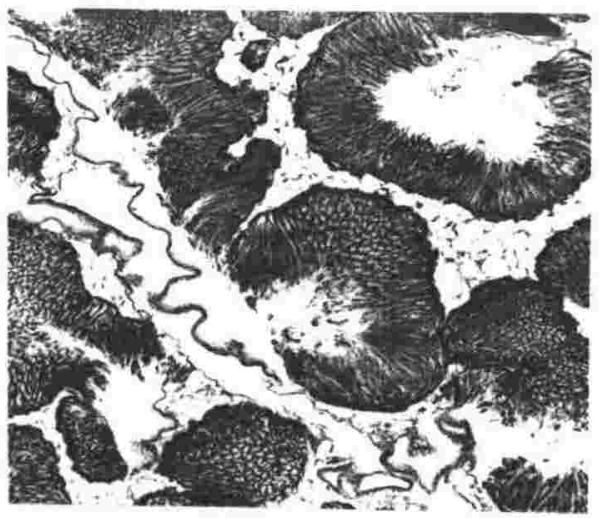

f

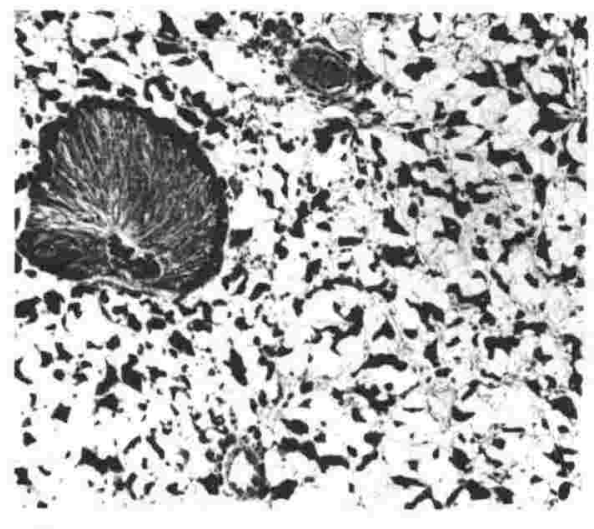


MYTILUS EDULIS AOTEANUS - FEMALE REPRODUCTIVE CYCLE
a) Stage I - onset of gametogenesis
b) Stage II - advanced gametogenesis
c) Stage III - ripe gonad
d) Stage IV - partially spawned gonad
e) Stage $V$ - final spawning stage
f) Stage VI - spent gonad
g) Stage VI hermaphroditic gonad - female follicle at upper left, male follicle at lower right.
h) Stage I following right after Stage VI - new oocytes budding off the follicular wall while old ova are undergoing autolysis. 


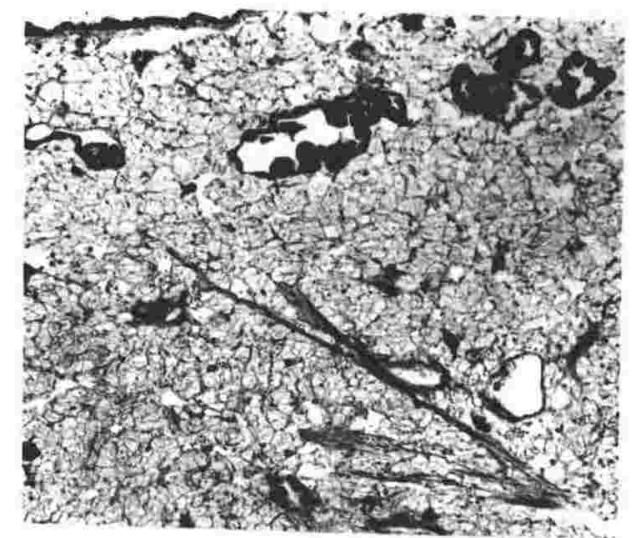

a

Ty 790 \%

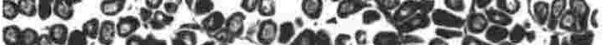

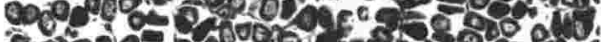
- 8 p

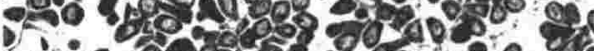

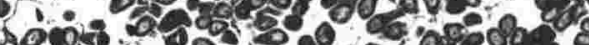


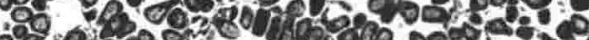

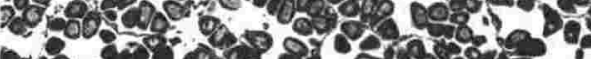

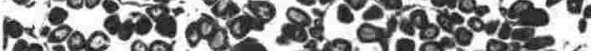
có 145 - 20 .

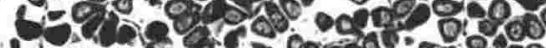

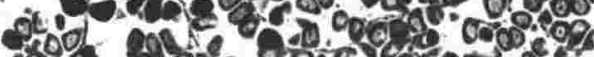

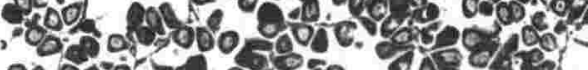
c
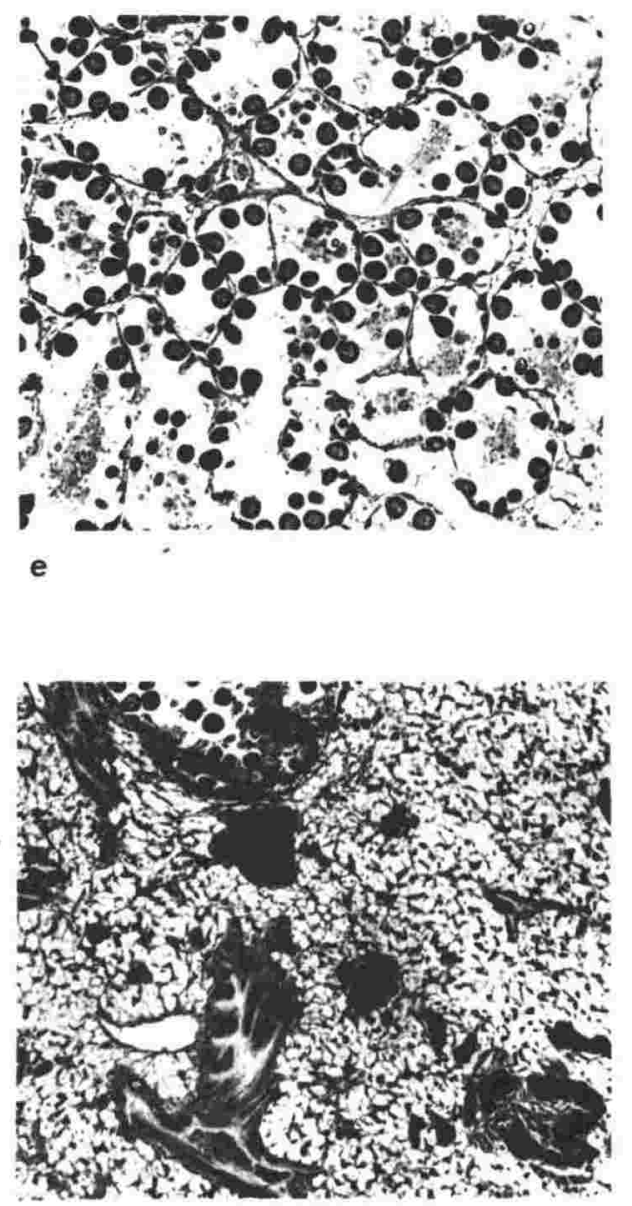

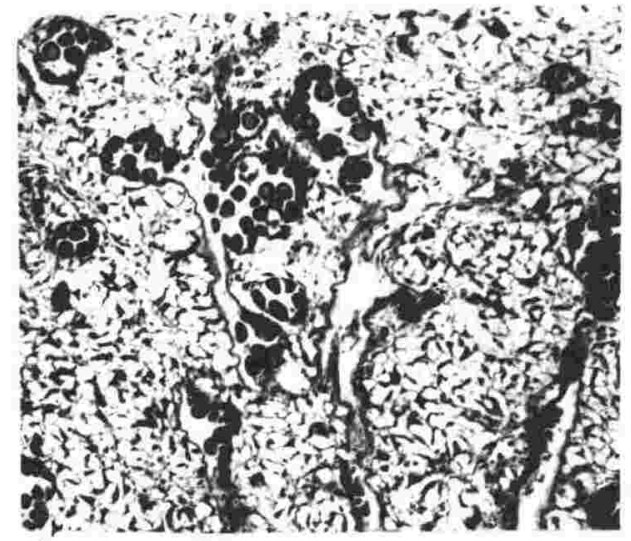

b
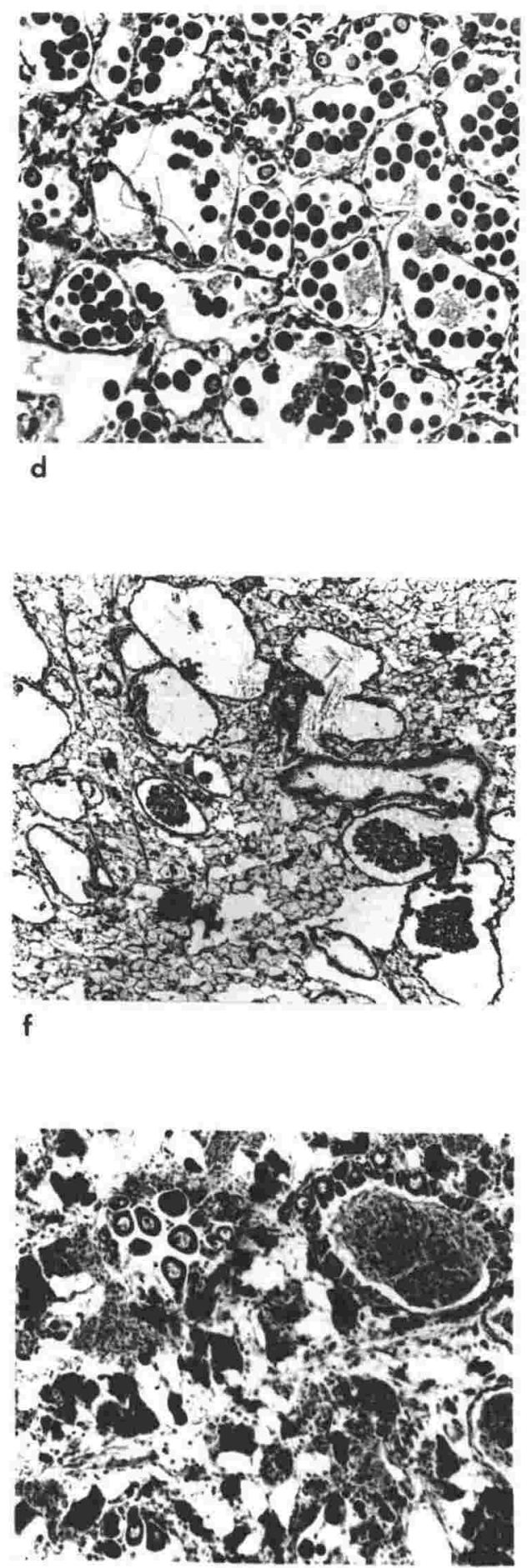

$\mathrm{h}$ 
ova were polygonal in shape due to the pressure exerted upon them by the overfull ovaries. In the male the ripe spermatozoa were oriented in the charcateristic lamellar arrangement. Mussels in this condition would spawn only if induced by the right stimulus. Once spawned the gametes were viable. The mussels entered into stage IV after their first spawning. This stage showed partly spawned follicles whose contents were not as tightly packed as in the preceding stage. The ova were now more spherical due to lack of pressure, while spermatozoa formed 'plugs' in the follicular lumen besides retaining the lamellar orientation. Gametogenesis was still evident as shown in the male by a thick peripheral band of darkstaining spermatogonia, and in the female by small oocytes budding from the follicular wall. The last stage of the spawning phase (Stage V) was similar to the preceding stage except for the reduced band of spermatogenetic tissue in the male, which at times was completely absent, and the absence of budding oocytes in the female. Amoebocytes were also present in the follicular lumen at this stage.

Stage VI, which marked the beginning of the recovery phase, was similar to stage $V$ apart from the presence of large numbers of amoebocytes and gametes undergoing autolysis. Mussels at this stage normally would not spawn again and would revert to the neuter stage 
(Stage VII) before commencing the cycle once more. In Mytilus however, and possibly even in perna to a lesser degree, some mussels seemed to enter into gametogenesis immediately following stage $V$ without their follicles regressing fully. Characteristic of this abnormal stage were the spermatogonia in the male and budding oocytes in the female at the same time as autolysing gametes in adjacent follicles. However, this stage was only observed in a small number of mussels and normally the follicles would regress until no trace of sexuality was visible and the mussel was then considered to have entered stage VII. Mussels in this stage were not necessarily thin or emaciated and unless starved, possessed substantial deposits of fat or glycogen (see Wilson \& Hodgkin 1967, Seed 1969a, Dare \& Edwards 1975, Flaws 1975, and others). Table 3.2 and Figures 3.3 and 3.4 summarize the findings for both species of mussels.

When sampling started at the end of March 1973, 90\% of Perna were in active spawning condition (Stages IV and $V$ ) with the rest being spent. The proportion of spent mussels increased until the beginning of July when gametogenesis commenced. While $90 \%$ of mussels were in gametogenesis (Stages I and II) until December, a small number (10\%) were in ripe condition and would have spawned if stimulated. S.pawned mussels were recorded again in December/January and their numbers 
PE RN A

\begin{tabular}{|c|c|c|c|c|c|c|c|c|c|c|c|c|c|c|c|c|c|c|}
\hline \multirow{3}{*}{ Date } & \multicolumn{9}{|c|}{ PE RNA } & \multicolumn{9}{|c|}{ MY T I LUS } \\
\hline & \multicolumn{3}{|c|}{ Total } & \multicolumn{5}{|c|}{ Stage } & \multicolumn{4}{|c|}{ Total } & \multicolumn{5}{|c|}{ Stage } & \\
\hline & $M$ & $\mathrm{~F}$ & 1 & 2 & 3 & 4 & 5 & 6 & 7 & M & F & 1 & 2 & 3 & 4 & 5 & 6 & 7 \\
\hline \multicolumn{19}{|l|}{1973} \\
\hline $29-3$ & 5 & 5 & 0 & 0 & 0 & 1 & 8 & 1 & 0 & 6 & 2 & 0 & 0 & 2 & 1 & 1 & 4 & 2 \\
\hline $1-5$ & 5 & 5 & 0 & 0 & 0 & 4 & 4 & 2 & 0 & 4 & 5 & 0 & 0 & 1 & 0 & 4 & 4 & 1 \\
\hline $2-6$ & 3 & 7 & 0 & 0 & 0 & 0 & 7 & 3 & 0 & 2 & 7 & 7 & 2 & 0 & 0 & 0 & 0 & 1 \\
\hline $7-7$ & 4 & 4 & 3 & 1 & 1 & 0 & 1 & 2 & 2 & 4 & 5 & 1 & 5 & 3 & 0 & 0 & 0 & 1 \\
\hline $4-8^{2}$ & 4 & 5 & 5 & 2 & 1 & 0 & 1 & 0 & 0 & 5 & 4 & 2 & 4 & 0 & $1^{3}$ & 1 & 2 & 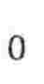 \\
\hline $30-8$ & 4 & 6 & 5 & 4 & 1 & 0 & 0 & 0 & 0 & 6 & 4 & 1 & 1 & 1 & 1 & 5 & 1 & 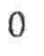 \\
\hline $27-9$ & 4 & 6 & 2 & 7 & 1 & 0 & 0 & 0 & 0 & 4 & 5 & 0 & 0 & 0 & 1. & 3 & 5 & U \\
\hline $24-11$ & 8 & 2 & 9 & 0 & 1 & 0 & 0 & 0 & 0 & & $\mathrm{n}$ & o & $\mathrm{s}$ & $\mathrm{a} \mathrm{m}$ & $p$ & $1 \mathrm{e}$ & & \\
\hline \multicolumn{19}{|l|}{1974} \\
\hline $14-1$ & 3 & 7 & 0 & 0 & 8 & 2 & 0 & 0 & 0 & 7 & 3 & 0 & 0 & 7 & 0 & 2 & 1 & 0 \\
\hline $4-2$ & 5 & 5 & 0 & 0 & 6 & 3 & 0 & 1 & 0 & 7 & 3 & 0 & 0 & 0 & 0 & 9 & 1 & 0 \\
\hline $11-2$ & 4 & 6 & 0 & 0 & 3 & 5 & 2 & 0 & 0 & & $\mathrm{n}$ & o & s & & $\mathrm{p}$ & $1 e$ & & \\
\hline $16-2$ & & $\mathrm{n}$ & 0 & $\mathrm{~s}$ & a & $\mathrm{mp}$ & $1 \mathrm{e}$ & e & & 3 & 7 & 0 & 0 & 0 & 0 & 8 & 2 & 0 \\
\hline $24-2$ & 6 & 4 & 0 & 0 & 4 & 3 & 2 & 1 & 0 & 4 & 6 & 3 & 0 & 0 & 1 & 1 & 5 & 0 \\
\hline $9-3$ & 5 & 5 & 0 & 0 & 0 & 1 & 9 & 0 & 0 & 1 & 8 & 0 & 0 & 1 & 0 & 4 & 4 & 0 \\
\hline $24-3$ & 4 & 6 & 0 & 0 & 0 & 0 & 8 & 2 & 0 & 2 & 8 & 0 & 0 & 1 & 3 & 4 & 2 & 0 \\
\hline $8-4$ & 3 & 7 & 0 & 0 & 0 & 0 & 4 & 6 & 0 & 2 & 8 & 0 & 0 & 3 & 1 & 3 & 3 & 0 \\
\hline Total & 67 & 80 & & & & & & & & 57 & 75 & & & & & & & \\
\hline $\begin{array}{l}1 \\
2 \\
3\end{array}$ & her & & & + & & & & & & & & & & & & & 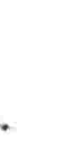 & \\
\hline
\end{tabular}

indeterminate sex - no follicles developed one mussel of indeterminate sex by parasitism hermaphroditic

MYT I LUS

TAB LE 3.2

OP THE BREEDINC CYCLE AT ELIE BAY

$\begin{array}{rlrcc}\text { Total Mussels } & \text { Male } & \text { Female } & \text { Asexual } & \text { Hermaphroditic } \\ \text { Perna : } 150 & 44.7 \% & 53.3 \% & 2.0 \% & 0.0 \% \\ \text { Mytilus : } 138 & 41.3 \% & 54.3 \% & 3.6 \% & 0.7 \%\end{array}$


FIGURE 3.3

Reproductive Cycle of Perna canaliculus.

FIGURE 3.4

Reproductive Cycle of Mytilus edulis aoteanus 

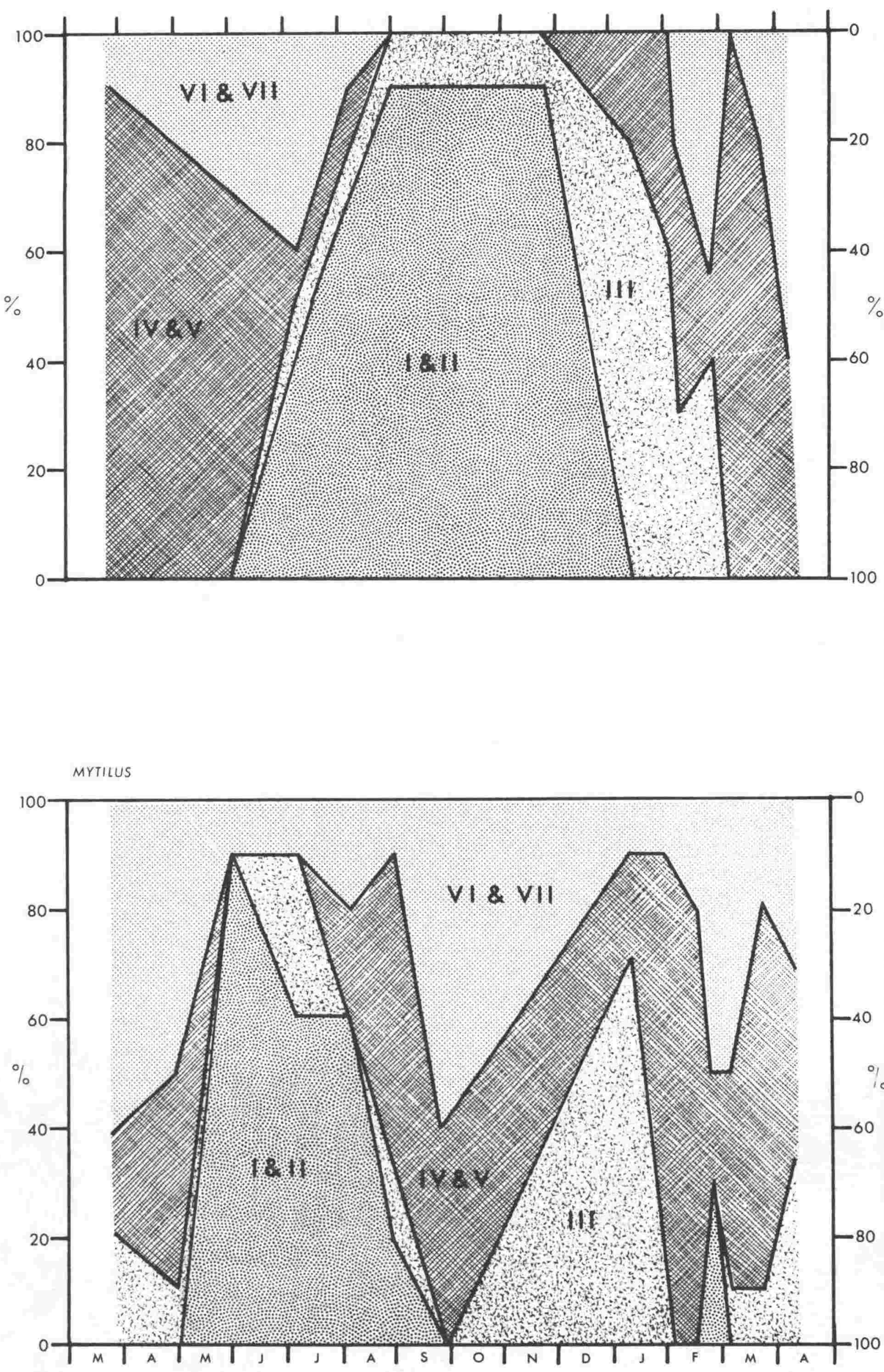
fluctuated in relation to ripe and spent individuals until the beginning of March 1974 when all of the mussels examined had spawned. By April, $60 \%$ of these mussels were spent and the annual reproductive cycle had been completed.

In March 1973 Mytilus were either in spawning condition or in the recovery stages. In June $90 \%$ of mussels were in gametogenesis and by July about $30 \%$ had ripe gonads (Stage III). The spawning season was nearly over by the end of september with $50 \%$ of mussels spent and $30 \%$ in the final spawning stages. However, by January most mussels were back in stage III only to be spent again by February. These latter mussels could have given rise to the small number (30\%) which, according to the present results, were in spawning condition during March and April 1974.

The reproductive cycle in perna exhibited a distinct season of gametogenic activity during the colder months of the year and while some ripe mussels were found throughout the year the season of actual spawning was restricted to summer and autumn when water temperature is normally higher. Spawning maxima occurred in March 1973 and again in March 1974, when the water temperature was $18 \pm 0.5^{\circ} \mathrm{C}$ and falling. The same temperature $\left(18 \pm 0.5^{\circ} \mathrm{C}\right)$ was recorded in January. However, at that time of the year the temperature was rising and although most mussels 
were ripe only restricted spawning was recorded.

Temperature is one of the most important exogenous factors which could influence the sequence and timing of events in the reproductive cycle of bivalves (Loosanoff 1945, Loosanoff \& Davis 1950, 1951, Allen 1955, Giese 1959, Wilson \& Hodgkin 1967, Flaws 1975). It appears from the present study that temperature may be responsible for the broad sequence of events in the reproductive cycle in Perna (see also Flaws, 1975). However specific details of the cycle such as the spawning season and the number and occurrence of peaks can be controlled by factors other than temperature (Thorson 1950, seed 1969a).

Durve (1965) and Matveyeva(1953) attributed spawning to a drop in salinity. Nelson (1954) reported spawning in oysters in response to the spring algal bloom and postulated that the food might be furnishing the bivalves with some necessary vitamins which may induce spawning activity. Mason (1958) found a relationship between tides and spawning in Pecten maximus. Battle (1932) considered the increase in hydrostatic pressure during spring tides as an influence on spawning and Korringa (1947) suggested that the sequence of dark and moonlit nights could be closely associated with spawning in areas with little or no tidal amplitude. 
It can be seen from Table 3.3 that of all physical environmental conditions monitored, only temperature was similar during the two peaks of spawning a year apart. While the mean air temperature was similar during pak spawning in both years, this normally fluctuates considerably from day to day and is not thought to have been responsible in stimulating spawning. Water temperature is not normally subjected

TABLE 3.3 ENVIRONMENTAL CONDITIONS DURING PEAK SPAWN ING

$\begin{array}{lcc} & \text { March } 1973 & \text { March } 1974 \\ \text { Water Tempe rature } & 18 \pm 0.5^{\circ} \mathrm{C} & 18 \pm 0.5^{\circ} \mathrm{C} \\ \text { Salinity } & 34.8^{\circ} / 00 & 33.0^{\circ} / 00 \\ \text { Rainfall } & 131.1 \mathrm{~mm} & 28.0 \mathrm{~mm} \\ \text { Wind Force (Daily } \bar{X} \text { ) } & 2.9 \mathrm{kn} & 3.3 \mathrm{kn} \\ \begin{array}{l}\text { Cloud Cover } \\ \text { (Daily } \bar{X} \text { in eighths) }\end{array} & 5.4 & 3.8 \\ \text { Air Temperature }(\bar{X}) & 16.35^{\circ} \mathrm{C} & 15.30^{\circ} \mathrm{C}\end{array}$

to wide fluctuations on a daily basis and the gradually falling water temperature appeared to have resulted in spawning at about $18^{\circ} \mathrm{C}$.

Spawning in bivalves has been observed in natural populations and induced in the laboratory by a temperature rise (Battle 1932, Loosanoff 1945, Iwatae19.51, Chipperfiela 1953, Bouxin 1956, Loosanoff \& Davis 1963) or fall 
Berner 1935, Savage 1956). Wilson \& Hodgkin (1967)

have shown that bivalves with tropical affinities

when near the poleward limit of their distribution,

tend to spawn in late summer and autumn when temperatures are falling.

Temperature appears responsible for the broad sequence of events as well as the finer details of the reproductive cycle in perna. A small number of ripe mussels can be found throughout the year and it seems likely that the appropriate temperature $\left(18 \pm 0.5^{\circ} \mathrm{C}\right)$, albeit on a local scale, will stimulate these few individuals into spawning, even at the 'wrong' time of the year. These unseasonal spawnings can obscure the general relationship between the reproductive cycle and temperature.

\subsubsection{Planktonic Larvae}

In decreasing order of abundance the most common bivalve groups in plankton samples from the Beatrix Basin were the Mytilidae, Ostreidae, Pinnidae and Pectenidae. The Mytilidae were represented by a number of genera the most common of which were Perna, Mytilus and Ryenella (see Plate 3.9).

Table 3.4 summarises the records of occurrence of these larvae in plankton samples and the conditions under which the samples were taken. 
Bivalve larvae in typical plankton sample from Elie Bay 


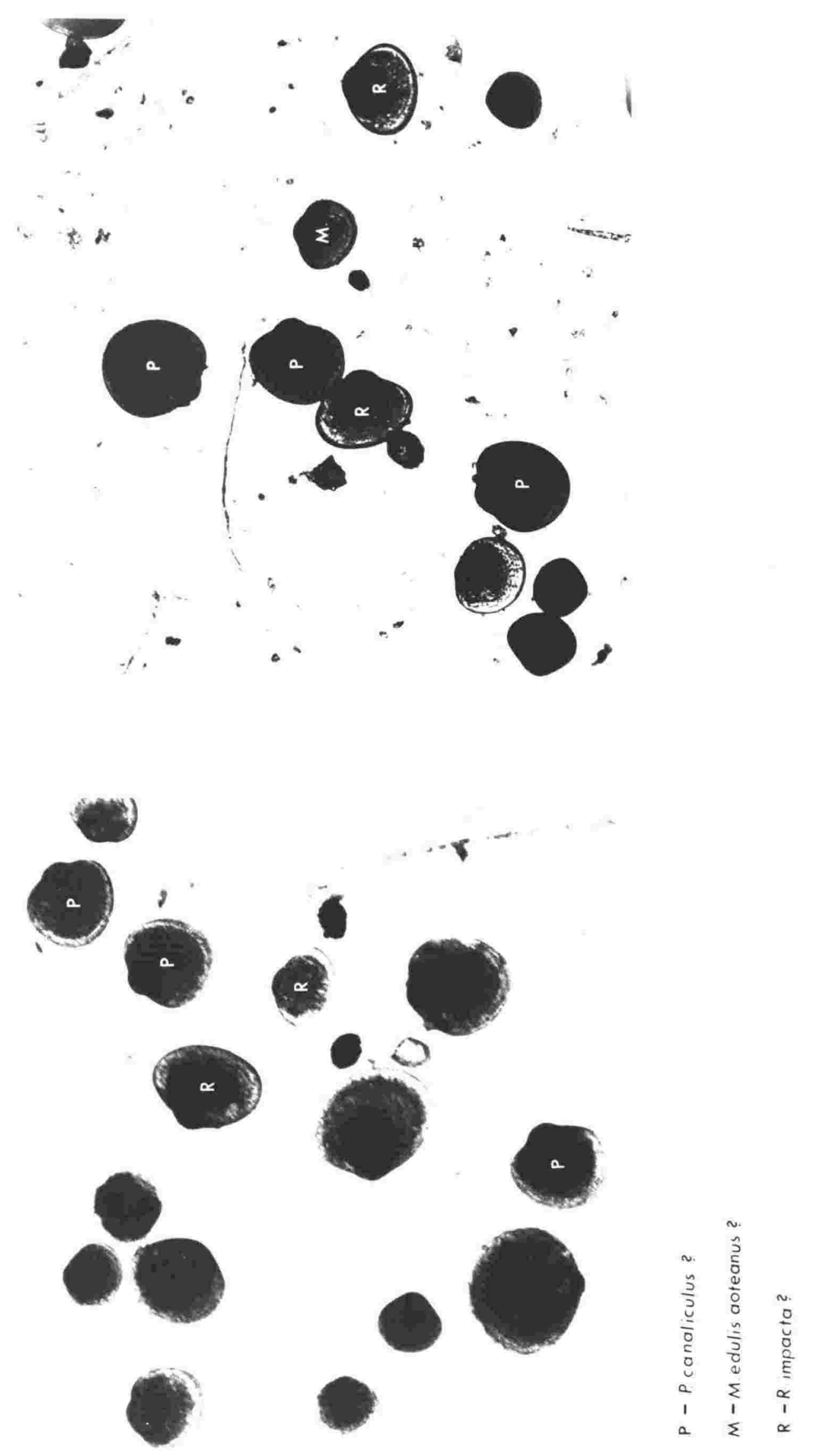


TABLE 3.4 DENSITY OF PLANKTONIC LARVAE PER SAMPLE OF 500 LITRES IN ELIE BAY

Date Tide Force Dim. Perna Mytilus Ryenella

\begin{tabular}{|c|c|c|c|c|c|c|c|}
\hline \multirow{23}{*}{1973} & & & & & & & \\
\hline & $22-7$ & $\uparrow$ & 1 & E & 1 & 0 & 0 \\
\hline & $25-7$ & $\uparrow$ & 1 & N & 0 & 2 & 0 \\
\hline & $28-7$ & $\downarrow$ & 4 & S & 4 & 2 & 0 \\
\hline & $1-8$ & $\uparrow$ & 4 & S & 0 & 1 & 0 \\
\hline & $4-8$ & $\uparrow$ & 1 & $\mathrm{~N}$ & 0 & 2 & 0 \\
\hline & $7-8$ & $\uparrow$ & 6 & S & 0 & 16 & 0 \\
\hline & $15-8$ & $\uparrow$ & 2 & $\mathrm{NE}$ & 0 & 9 & 0 \\
\hline & $21-8$ & $\uparrow$ & 0 & 0 & 0 & 0 & 0 \\
\hline & $24-8$ & $\uparrow$ & 1 & $\mathrm{~N}$ & 0 & 16 & 0 \\
\hline & $27-8$ & $\uparrow$ & 0 & 0 & 0 & 29 & 0 \\
\hline & $1-9$ & $\uparrow$ & 4 & $\mathrm{~N}$ & 0 & 4 & 0 \\
\hline & $4-9$ & $\uparrow$ & 1 & $\mathrm{~N}$ & 0 & 0 & 0 \\
\hline & $7-9$ & $\uparrow$ & 5 & $\mathrm{~N}$ & 0 & 0 & 0 \\
\hline & $12-9$ & $\uparrow$ & 3 & E & 0 & 82 & 0 \\
\hline & $17-9$ & $\uparrow$ & 5 & SE & 0 & 63 & 0 \\
\hline & $20-9$ & $\uparrow$ & 1 & SE & 0 & 5 & 0 \\
\hline & $23-9$ & $\uparrow$ & 1 & $\mathrm{~N}$ & 0 & 150 & 0 \\
\hline & $26-9$ & $\uparrow$ & 1 & NW & 0 & 22 & 0 \\
\hline & $4-10$ & $\uparrow$ & - & - & 0 & 10 & 0 \\
\hline & $8-10$ & $\uparrow$ & 2 & $\mathrm{~N}$ & 0 & 39 & 0 \\
\hline & $14-10$ & $\uparrow$ & 5 & $\mathrm{~N}$ & 0 & 26 & 0 \\
\hline & $20-10$ & $\uparrow$ & 1 & W & 0 & 144 & 0 \\
\hline & $30-10$ & $\uparrow$ & 5 & $\mathrm{~N}$ & 0 & 1 & 0 \\
\hline & $4-11$ & $\uparrow$ & 3 & $\mathrm{~N}$ & 0 & 0 & 0 \\
\hline & $10-11$ & $\uparrow$ & 3 & S & 0 & 0 & 0 \\
\hline & $16-11$ & $\uparrow$ & 3 & S & 0 & 0 & 0 \\
\hline & $23-12$ & $\downarrow$ & - & - & 0 & 7 & 1 \\
\hline & $27-12$ & $\psi$ & 4 & $\mathrm{~N}$ & 25 & 0 & 100 \\
\hline & $30-12$ & $\uparrow$ & 2 & N & 200 & 0 & 40 \\
\hline \multirow{20}{*}{1974} & $4-1$ & $\uparrow$ & 4 & SE & 100 & 50 & 150 \\
\hline & $6-1$ & $\uparrow$ & 6 & $\mathrm{~N}$ & 10 & 15 & 5 \\
\hline & $9-1$ & $\uparrow$ & 1 & $S$ & 0 & 0 & 10 \\
\hline & $11-1$ & $\uparrow$ & 1 & $\mathrm{NW}$ & 19 & 0 & 0 \\
\hline & $14-1$ & $\uparrow$ & - & - & 200 & 50 & 100 \\
\hline & $17-1$ & $\uparrow$ & 6 & S & 5 & 0 & 21 \\
\hline & $19-1$ & $\uparrow$ & 1 & $\mathrm{~N}$ & 5 & 4 & 4 \\
\hline & $21-1$ & $\uparrow$ & 1 & $\mathrm{~N}$ & 50 & 4 & 0 \\
\hline & $23-1$ & $\uparrow$ & 3 & S & 300 & 0 & 100 \\
\hline & $25-1$ & $\downarrow$ & 5 & SE & 10 & 10 & 5 \\
\hline & $27-1$ & $\downarrow$ & 4 & S & 50 & 0 & 0 \\
\hline & $30-1$ & $\downarrow$ & 1 & $\mathrm{~N}$ & 85 & 15 & 0 \\
\hline & $4-2$ & $\downarrow$ & 4 & $\mathrm{~N}$ & 28 & 12 & 20 \\
\hline & $16-2$ & $\uparrow$ & 5 & S & 0 & 0 & 20 \\
\hline & $23-2$ & $\downarrow$ & 1 & $\mathrm{~N}$ & 2 & 1 & 1 \\
\hline & $28-2$ & $\uparrow$ & - & - & 1 & 0 & 0 \\
\hline & $9-3$ & $\uparrow$ & 3 & S & 200 & 4 & 150 \\
\hline & $22-3$ & $\downarrow$ & 1 & E & 0 & 2 & 0 \\
\hline & $26-3$ & $\uparrow$ & 2 & $\mathrm{~N}$ & 2 & 0 & 0 \\
\hline & $8-4$ & $\uparrow$ & - & - & 3 & 2 & 0 \\
\hline
\end{tabular}

$\uparrow$ - tide rising

$\downarrow$ - tide falling

(Note: no larvae were found between Jume 3 and July 18) 
In Elie Bay Perna larvae were found in plankton samples from late December 1973 to April 1974 and, except for a small number (4 larvae/500 litres) at the end of July, were absent during the rest of the year (Figure 3.5). Perna larval densities increased markedly in January (100-200 larvae/500 litres) and apart from daily fluctuations these numbers persisted into early February. In mid-February there was a decrease in larval concentration which lasted for about 15 days. There was another increase to 200 larvae/500 litres in early March, but numbers had fallen again by the end of the month.

Mytilus larvae were found in high concentrations (ca 150) 500 litres) between september and October 1973 and a lower peak (50/500 litres) was recorded in January 1974 . They were absent from samples from Elie Bay for the rest of the year (see Figure 3.5).

Ryenella larvae are morphologically similar to larvae of Perna of the same age. It was decided to record their occurrence because of this similarity. High concentrations (100-150 larvae/500 litres) were found in late December 1973. Numbers fluctuated but similar concentrations occurred again in January and March 1974. Larvae were entirely absent in samples between the end of March and end of December. Ryenella larvae were present at the same time of the year as perna larvae. 
The occurrence and concentration of pelagic larvae of perna canaliculus (upper figure) and Mytilus edulis aoteanus (lower figure) in 500 litre plankton samples taken at Elie Bay between June 1973 and April 1974 


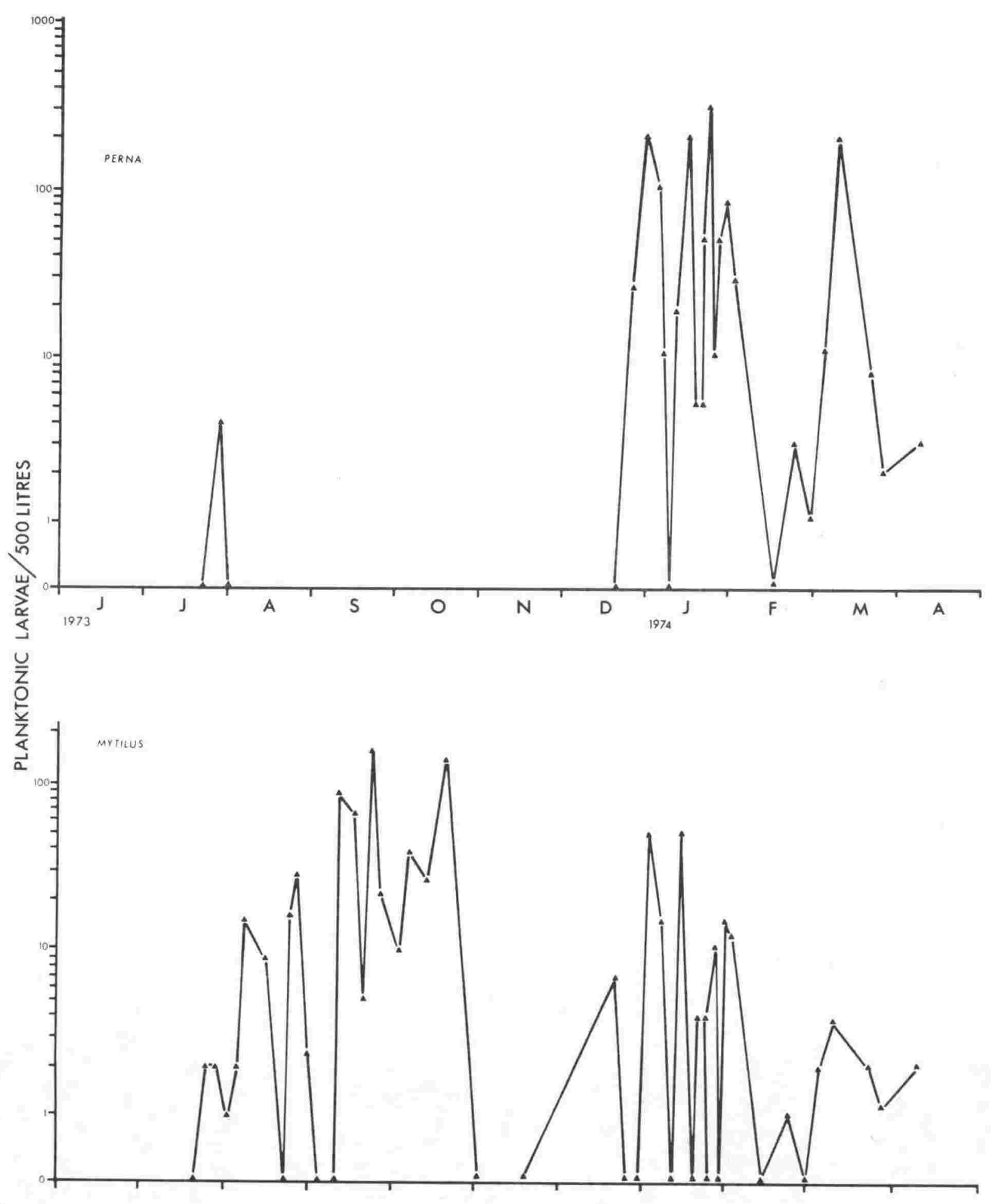


TABLE $\quad 3.5$ PLANKTON SAMPLES TAKEN FROM THREE SITES IN BEATRIX BASIN ON THE SAME DAY

\begin{tabular}{|c|c|c|c|c|c|c|c|c|c|}
\hline \multirow{2}{*}{ DATE } & \multicolumn{3}{|c|}{ ELIE } & \multicolumn{3}{|c|}{ WAI MARU } & \multicolumn{3}{|c|}{ BEATRI X } \\
\hline & $\mathrm{p}$ & M & $\mathrm{R}$ & $\mathrm{P}$ & M & $\mathrm{R}$ & P & M & $\mathrm{R}$ \\
\hline $4-1-74$ & 100 & 50 & 150 & 200 & 100 & 150 & 120 & 60 & 90 \\
\hline $14-1-74$ & 200 & 50 & 100 & 250 & 40 & 80 & 180 & 50 & 120 \\
\hline $4-2-74$ & 28 & 12 & 20 & 55 & 28 & 25 & 25 & 8 & 25 \\
\hline $26-3-74$ & 2 & 0 & 0 & 0 & 0 & 0 & 0 & 0 & 0 \\
\hline $8-4-74$ & 3 & 2 & 0 & 0 & 1 & 0 & 0 & 0 & 0 \\
\hline TOT ALS & 333 & 114 & 270 & 505 & 169 & 255 & 325 & 118 & 235 \\
\hline $\bar{x}$ & 66.6 & 22.8 & 54.0 & 101 & 33.8 & 51.0 & 65.0 & 23.6 & 47.0 \\
\hline$P=$ Perna & canal & culus & & & & & & & \\
\hline$M=$ Myti 1 & is edu & is ao & eanus & & & & & & \\
\hline
\end{tabular}

Larval counts from samples from Elie, Waimaru and Beatrix Bays as shown in Table 3.5 above indicate that on days when larvae are abundant at one station, they are also abundant at the other stations. Waimaru Bay appears to register consistently higher concentrations of Perna larvae and the difference between this and the other two stations is significant $\left(x^{2}=53.305\right)$. However, the difference in concentration of Mytilus larvae between the three stations is less significant $\left(x^{2}=14.037\right)$, while the difference for Ryenella larvae is non-significant $\left(x^{2}=2.439\right)$. 
Since it appears that water temperature may be used to predict spawning, prediction of spatfall would also be possible if the duration of the pelagic larval life was known. Unfortunately, opinion regarding the length of pelagic life of mussel larvae varies between one week and four months (White 1937, Thorson 1946, Chipperfield 1953, Bayne 1965, Lubet 1969, Hrs-Brenko 1973) and is influenced by environmental conditions. Warm water temperature and sufficient food can reduce the pelagic phase to a few weeks (Hrs-Brenko, 1973) while larvae that are spawned in late autumn and winter are often retarded and probably remain in the plankton for up to four months.

Survival is a function of predation and physical environmental conditions. Planktotrophic (see Thorson, 1950) larvae are at the mercy of many predators including pelagic larval stages of a number of marine animals as well as benthic filter-feeders. Thorson (1946) estimated that a medium-sized Mytilus edulis filtering 1.4 litres of water per hour, may retain and kill about 100,000 pelagic bivalve larvae in 24 hours under certain conditions.

Favourable climatological conditions often result in high survival rates (Savage, 1956), but mussel larvae often "succumb to sudden falls in temperature and are swept up on the shore by winds, waves and tidal currents 
to perish by the millions" (Field, 1922).

Unfavourable environmental conditions need not destroy the larvae, but they can still influence their dispersal, thus affecting plankton sampling. Booth (1972) listed nine physical factors which could influence the distribution of bivalve larvae. He recorded a fairly even distribution throughout Wellington Harbour, but found the distribution in the Bay of Islands more 'patchy'. Manning \& Whaley (1954) found that prevailing winds were the major influence in determining horizontal distribution of oyster larvae and subsequent settlement. Verwey (1952) stressed the importance of water currents and velocity in transporting young mussels. Rapson (1952) noticed swarming by Amphidesma ventricosum larvae and attributed this to wave action on the beach.

Jenkins (1974) found that some localities in Kenepuru Sound were consistently better than others in their density of planktonic larvae although there were exceptions. Variations in larval densities from stations within the same general area have been recorded also by Hrs-Brenko (1974) and by Lutz (1974), even after spawning was known to have taken place simultaneously over the entire area. Perna larvae appear to have been concentrated at Waimaru Bay during the present study by the action of the wind and tide which act on the eastern region more than on either of the other regions 
(see Section Two). However, it is not known why Mytilus and Ryenella did not show a similar distribution pattern.

Mussel larvae are not entirely passive nor at the mercy of the environment. Bayne (1963, 1964b) recorded the response of mussel larvae to hydrostatic pressure, light and gravity. The influence of temperature and salinity on bivalves and their larvae have been well recorded (Kinne 1963,1964, Hrs-Brenko \& Calabrese 1969, Calabrese \& Davis 1970, Lough 1974, Wallis 1975, Kennedy 1976). The detection and avoidance of cuprous oxide anti-fouling paint by mussel larvae was studied by Wisely (1963).

Kunkle (1957) and Booth (1972) found that bivalve larvae were evenly distributed in the water column during most of the flood tide but at late flood they congregated near the bottom and stayed there throughout the ebb tide. This was attributed to tidal currents and turbulence. However, Perkins (quoted by Nelson, 1954) stated that "oyster larvae are distributed vertically in the waters of Barnegat Bay by their own activity in response to salinity changes." Wood \& Hargis (1971) reached the same conclusion, but Carriker (1951) went further and noticed that the younger stages had a fairly even distribution in the water column, while older larvae tended to remain near the bottom. It was not always possible to sample on the rising tide during the present study (see Table 3.4). However, this is not thought to have introduced any 
variability since salinity does not alter appreciably during each tidal cycle and each sample was taken so as to include a cross-section of the entire water column.

While spontaneous spawning by ripe mussels out of phase with the main population may result in groups of pelagic larvae which tend to confuse any attempts to predict spatfall, the variability and range of possibilities resulting from the pelagic phase itself are more effective in hindering any spatfall predictions based on the presence or absence of planktonic larvae.

\subsubsection{Settlement}

A) Season and Survival

Results from the short term collectors are summarised in Table 3.6 and Figure 3.6. Settlement of Perna increased from a daily mean of 0.3 mussels between 27 September and 27 October 1973, to 8.8 mussels per day between 3 and 21 December. The peak (mean settlement 7.7 mussels/ day) lasted until 4 January_ 1974. Daily settlement then fell to a mean of between 3 and 6 mussels. A new peak of 11.3 mussels/day was registered between 16 and 23 February and after low settlement totals for a fortnight, the last and highest peak (13.5 mussels/day) took place between 9 and 22 march. A rapid decline in settlement soon followed. 
TABLE 3.6 MUSSEL SETTLEMENT ON SHORT TERM COLLECTORS AT ELIE BAY

\begin{tabular}{|c|c|c|c|c|c|c|c|c|c|c|c|c|}
\hline 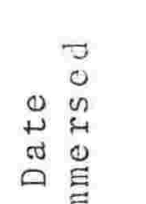 & 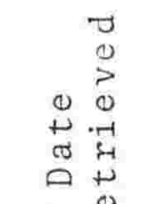 & 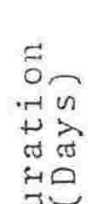 & & $\begin{array}{l}\text { I R } \\
\text { PE }\end{array}$ & & & & $\begin{array}{l}\text { ACK } \\
\text { LM }\end{array}$ & & IAL & DAI & $L Y \bar{X}$ \\
\hline$\stackrel{E}{\mapsto}$ & $\approx$ & 官 & $\mathrm{p}$ & $M$ & $\mathrm{P}$ & M & $\mathrm{P}$ & M & $\mathrm{P}$ & M & $\mathrm{P}$ & M \\
\hline $\begin{array}{r}1973 \\
27-9\end{array}$ & $27-10$ & 30 & 0 & 63 & 3 & 30 & 5 & 55 & 8 & 148 & 0.3 & 4.9 \\
\hline $7-10$ & $23-11$ & 27 & 7 & 51 & 2 & 15 & 10 & 145 & 19 & 211 & 0.7 & 7.8 \\
\hline $23-11$ & $3-12$ & 10 & 6 & 0 & 17 & 4 & 43 & 15 & 66 & 19 & 6.6 & 1.9 \\
\hline $3-12$ & $21-12$ & 18 & 23 & 6 & 78 & 1 & 74 & 9 & 158 & 16 & 8.8 & 0.9 \\
\hline $21-12$ & $\begin{array}{l}1974 \\
4-{ }^{4}\end{array}$ & 14 & 65 & 15 & 46 & 7 & 31 & 12 & 92 & 34 & 6.6 & 2.4 \\
\hline $4-1$ & $14-1$ & 10 & 10 & 10 & 9 & 1 & 9 & 7 & 28 & 18 & 2.8 & 1.8 \\
\hline $14-1$ & $25-1$ & 11 & 26 & 0 & 6 & 0 & 8 & 0 & 40 & 0 & 3.6 & 0.0 \\
\hline $25-1$ & $30-1$ & 5 & 5 & 0 & 11 & 0 & 0 & 0 & 16 & 0 & 3.2 & 0.0 \\
\hline $30-1$ & $4-2$ & 5 & 7 & 2 & 19 & 0 & 5 & 0 & 31 & 2 & 6.2 & 0.4 \\
\hline $4-2$ & $16-2$ & 12 & 14 & 2 & 17 & 0 & 7 & 0 & 38 & 2 & 3.2 & 0.2 \\
\hline $16-2$ & $23-2$ & 7 & 25 & 1 & 34 & 0 & 20 & 0 & 79 & 1 & 11.3 & 0.2 \\
\hline $23-2$ & $27-$ & 4 & 0 & 0 & 8 & 0 & 4 & 0 & 12 & 0 & 3.0 & 0.0 \\
\hline $27-2$ & $9-3$ & 10 & 8 & 0 & 2 & 0 & 20 & 0 & 30 & 0 & 3.0 & 0.0 \\
\hline $9-3$ & $22-3$ & 13 & 62 & 0 & 42 & 0 & 72 & 0 & 176 & 0 & 13.5 & 0.0 \\
\hline $22-3$ & $26-3$ & 4 & 2 & 0 & 1 & 0 & 3 & 0 & 6 & 0 & 1.5 & 0.0 \\
\hline $26-3$ & $8-$ & 13 & 0 & 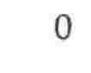 & 2 & 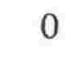 & 0 & 0 & 2 & 0 & 0.1 & 0,0 \\
\hline & Т 07 & & 260 & 150 & 297 & 58 & 311 & 243 & 801 & 451 & & \\
\hline
\end{tabular}

P - Perna cana1iculus

$M$ - Mytilus edulis aoteanus 
Daily mean settlement of Perna canaliculus and Mytilus edulis aoteanus at Elie Bay between October 1973 and April 1974. The data represents total settlement on three collectors as given in Table 3.6 


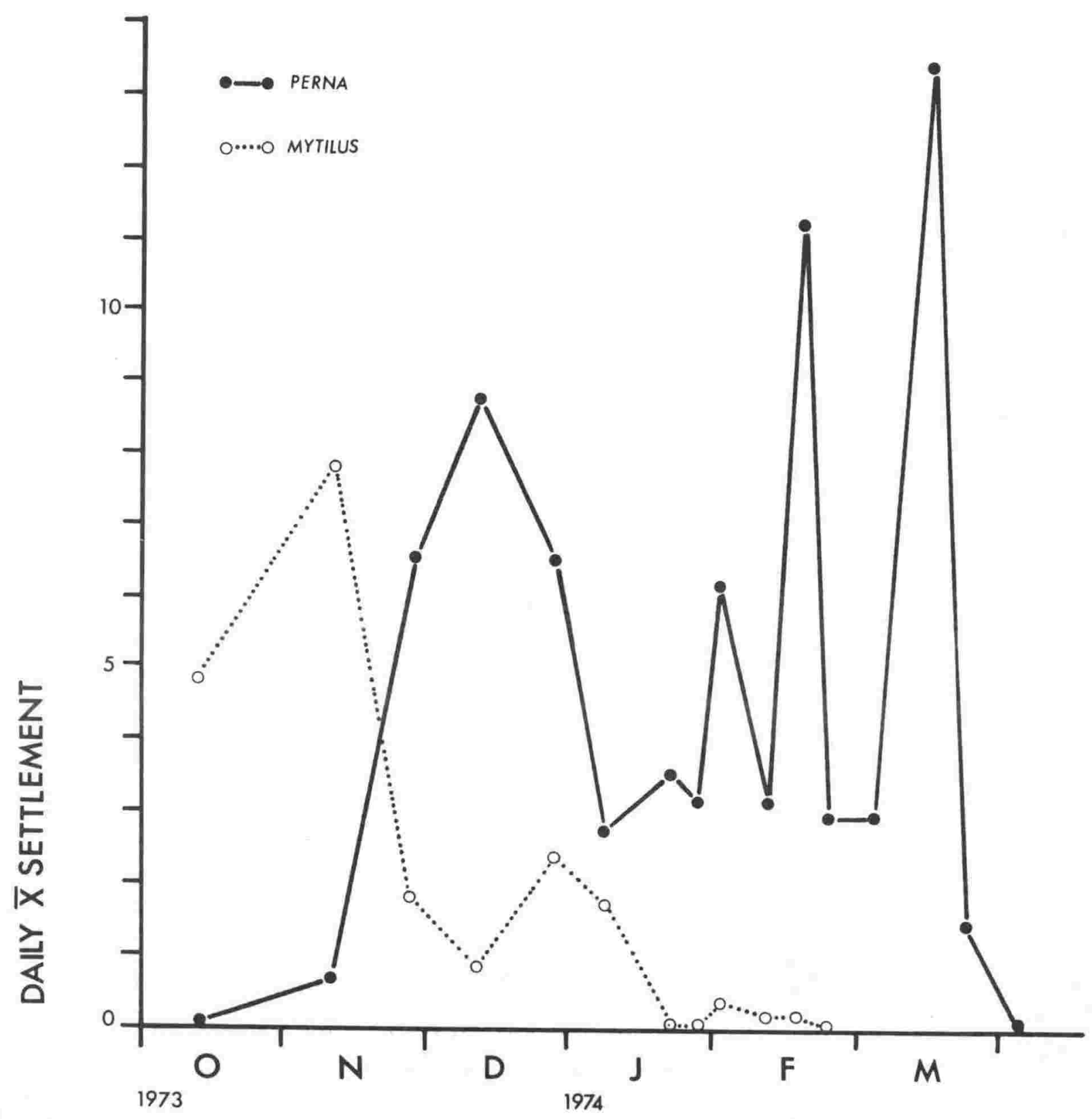


When sampling started in September 1973, Mytilus settlement was probably already declining since it did not recover after a peak ( 7.8 mussels/day) which occurred between 27 october and 23 November. Settlement after mid-January was extremely sparse.

Long term collectors were recovered on 8 April 1974 and the mussels settled on them removed, graded according to size and counted. By reducing the tallies for each size class to percentages of the total on each collector, a better comparative picture emerged. It can be seen from Table 3.7 and Figure 3.7 that there are three size peaks : larger than $20 \mathrm{~mm}$, between $1 \mathrm{~mm}$ and $10 \mathrm{~mm}$ and smaller than $500 \mu \mathrm{m}$.

Mussels larger than $20 \mathrm{~mm}$ ( 45 individuals between 15 collectors) settled prior to 4 January 1974 since they were absent from collectors put out after that date. They settled after 21 December 1973 since they were to be found on collectors put out on that date. Settlement on the short term collectors during the same period (21 December to 4 January) totalled 120 mussels between three collectors. This represents a survival rate of about $37 \%$ and a growth rate of about $10 \mathrm{~mm}$ per month since some of the survivors reached a length of $35 \mathrm{~mm}$ during the study period.

The same criteria were used to establish that the lmm-lomm class mussels had settled between 16 and 23 


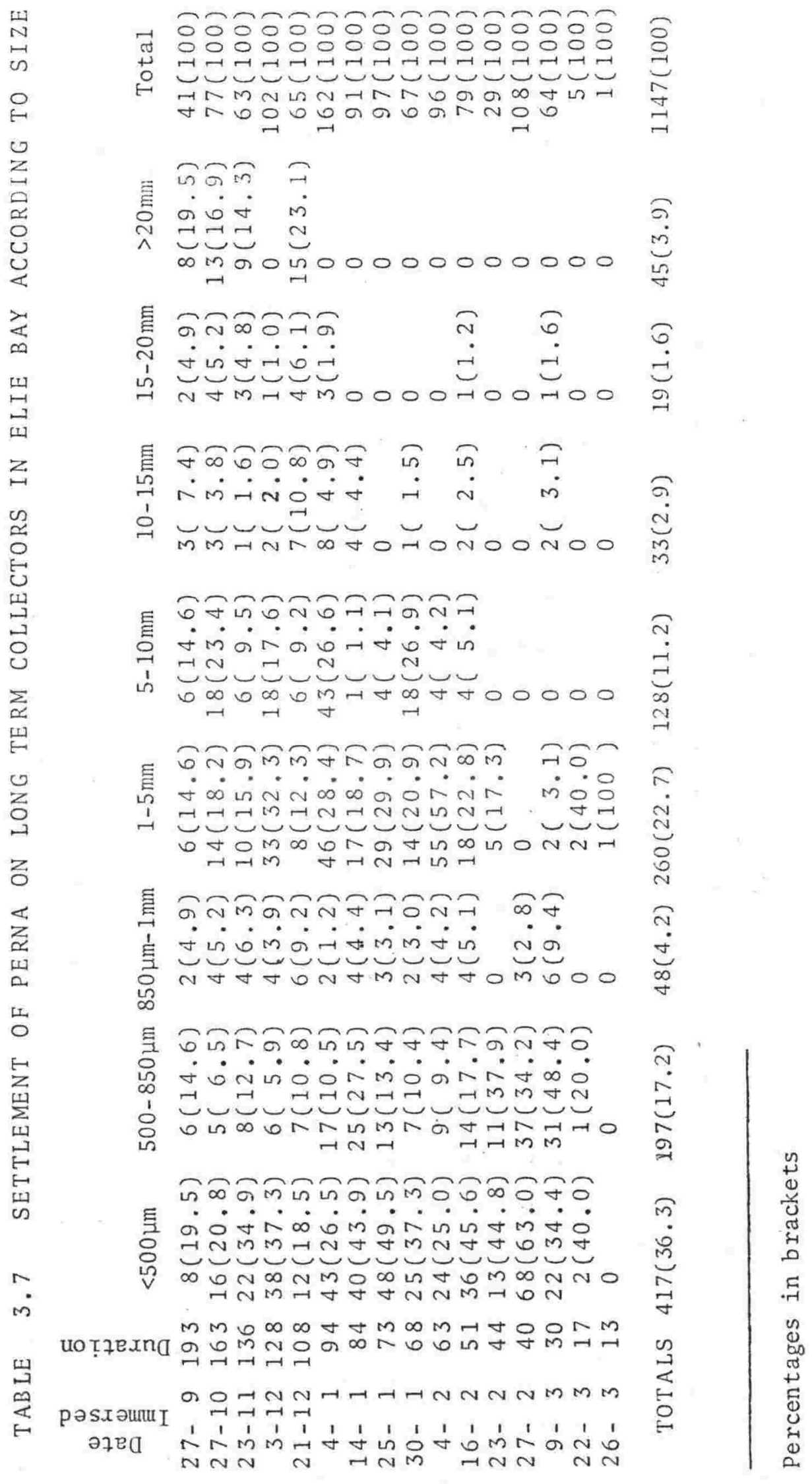


Size class distribution of settled Perna canaliculus on collectors of different ages at Elie Bay between September 1973 and March 1974. 


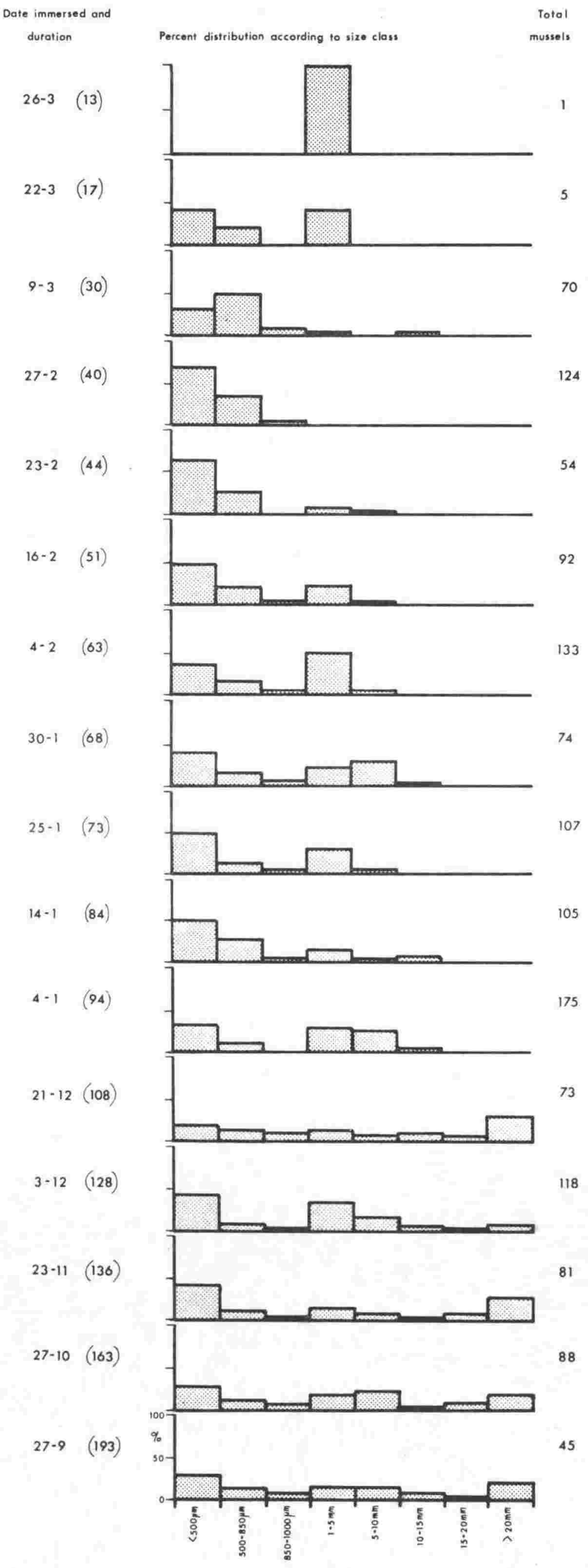


February 1974 and had a survival rate of about $46 \%$ Mussels smaller than $500 \mu \mathrm{m}$ settled between 9 and 22 March and their survival rate was about $24 \%$.

Nelson (1928) said that larvae that by chance happen to "fall upon good ground" are much less numerous than the vast hordes which "fall by the wayside" and are lost. Further losses are to be expected even after "falling upon good ground". Information on the survival rates of mussels settled naturally on commercial ropes is not available. Survival on manually seeded ropes ranges from 100\% (Yap et al, 1976) to less than 2\% (Dare \& Davies, 1975). Overcrowding appears to be the main cause of these high losses. Other causes are turbulence, high current speeds, drifting fucoid and other weeds and debris, predation and dislodgement of mussel clumps from the ropes under their own weight.

Starfish, whelks, sea urchins, crabs, many finfish, birds, muskrats and walruses are among the large number of predators that mussels have to face (Field 1922, Newcombe 1935, Kitching et al 1959, Hancock 1960, Flaws 1968, Urosa 1972). Predation is often the selective force resulting in the characteristic distribution of mussels in the littoral and sub-littoral zones (Seed 1969b, Dayton 1971, Paine 1971, Flaws 1975). Mussels grown by suspension culture are beyond the reach of most predators (Andreu, 1968a). However, they are still subjected to predation by some finfish and diving birds (Mason, 1969, 
1971), and probably by flatworms (see Landers \& Rhodes, 1970).

No starfish or whelks were found on the culture ropes during the present study. However, leatherjacket Navodon scaber) and pipefish (Stigmatophora longirostris) were both found closely associated with the ropes and could have preyed on small mussels although their main objective probably was amphipods. The snapper (Chrysophrys auratus) was also noticed in the vicinity of the rafts and was thought to have similar behaviour. Many local mussel farmers in the Marlborough Sounds are of the opinion that snapper is an active predator on mussels and examination of stomach contants supported this belief (I. Batenberg, P. Yealands, pers. comm.). In the absence of more direct proof these conclusions must remain tentative. Mussel rafts decked with a full complement of ropes appear to provide an attractive habitat for reef-dwelling fish. Under these circumstances losses through predation appear inevitable.

Some of the experimental rafts were adopted as regular roosts by groups of black-backed gulls (Larus dominicanus). These birds were not observed to prey on mussels and this was confirmed by examination of their droppings which showed euphausids as the main component of their diet.

Among the invertebrate fauna on mussel ropes were three 
potential predators : a crab (Halicarcinus cookiih, an errant polychaete (Lepidonotus sp.) and an unidentified polyclad flatworm (tentatively identified as Stylochus sp). The crabs and polychaetes are thought to have preyed only on small mussels if at all. Flatworms are known to prey on adult oysters (Provenzano 1961, Brick 1970) and the presence in this study of groups of up to ten worms inside empty shells, is at least circumstantial evidence that they may prey on mussels. It is not known whether they restrict their attacks to weak or dying mussels or attack healthy individuals as well.

Mussels apparently have few parasites or pathogens (Field, 1922). Mytilicola intestinalis is probably the only serious parasite in Mytilus edulis and in some European culture areas it poses a problem for the mussel industry (cole \& Savage 1951, Nunes 1951, Korringa 1951, Waugh 1954, Mann 1956, Andreu 1960, Brienne 1960, and others). This parasite is absent from New Zealand mussels. However, Jones (1975a) found five possible parasites in Perna including the pea crab (Pinnotheres novaezelandiae), two copepods (Lichomolgus uncus and Pseudomyicola spinosus), a digenic trematode (Tergestia agnostomi) and a sporozoan (Nematopsis sp.) (see also Jones 1975b).

It is debatable whether the pea crab is a parasite or a commensal, but it can cause injury to the infected mussels which are usually emaciated. It was encountered in 6-8\% of raft-grown Mytilus during the present study 
however, it was found in only 1\% of Perna. Pea crabs are known to be more common in mussels from natural beds rather than from rafts.

In some areas the trematode Tergestia agnostomi can be very common with up to $30 \%$ of mussels infected (Jones, 1975a). An infected mussel is usually rendered asexual but does not seem affected in any other way. No harmful effects have been reported in humans ingesting infected mussels.

In the absence of direct evidence that any of the small number of known parasites are causing mortality among mussels, losses are attributed to predation and water movement (directly or indirectly). The raft in Elie Bay was removed from the mainstream of tidal. currents but movement of the raft caused by wind action could have jerked small mussels off the ropes.

A further possible loss of spat is migration after the original settlement. Some mussels in the $1 \mathrm{~mm}-10 \mathrm{~mm}$ class were found on the collectors after 23 February (the estimated last date for settlement). One mussel measuring $2.5 \mathrm{~mm}$ was found on a 13-day old collector. It is possible that these mussels, larger than expected for their estimated age, represent secondary settlement. Bayne (1965) has shown that mussels may have a secondary pelagic phase followed by a second settlement. This can account for the sudden appearance of juvenile mussels 
on collector ropes. If secondary settlement of juvenile mussels was taking place during the present study, it is probable that the $42 \%$ survival rate recorded for the $1 \mathrm{~mm}-10 \mathrm{~mm}$ class was inflated by recruitment.

\section{B) Depth Preference}

The total number of mussels settled during this experiment at Elie Bay was 15199 of which 8319 were Perna and 6880 Mytilus (see Table 3.8). Over half (56.9\%) of the Perna settlement occurred between $140 \mathrm{~cm}$ and $280 \mathrm{~cm}$ from the surface. Mytilus showed a similar trend in its distribution.

Settled mussels were sorted according to eight size classes. Over $94 \%$ of Perna and $97 \%$ of Mytilus were below $5 \mathrm{~mm}$. The largest number of mussels of both species were within the $500 \mu \mathrm{m}-1.0 \mathrm{~mm}$ group. A distinctly higher proportion of the larger mussels was found within $70 \mathrm{~cm}$ of the surface (See Table 3.9 and Figure 3.8 ) but no definite pattern of distribution by size against depth could be determined.

The collectors were examined for possible competing organisms with reference to distance from the surface. Table 3.8 shows distribution of mussels and competitors by depth at Elie Bay. The most numerous competitors were amiphipods with a maximum density of 4200 per collector at a depth of between $210 \mathrm{~cm}$ and $245 \mathrm{~cm}$. 
TAB LE 3.8 PERCENTAge Settlement of MUSSEls AND

Depth $\mathrm{cm}$ PERNA MYTILUS RYENELLA HIATELLA AMPHIPODS POLYCHAETES

\begin{tabular}{|c|c|c|c|c|c|c|}
\hline $0-\quad 35$ & $\begin{array}{r}5.6 \\
(470)\end{array}$ & $\begin{array}{r}9.6 \\
(660)\end{array}$ & $\begin{array}{r}13.0 \\
(1897)\end{array}$ & $\begin{array}{c}21.1 \\
(305)\end{array}$ & $\begin{array}{r}8.3 \\
(15675)\end{array}$ & $\begin{array}{r}6.9 \\
(125)\end{array}$ \\
\hline $35-70$ & $\begin{array}{r}5.5 \\
(459)\end{array}$ & $\begin{array}{r}6.5 \\
(449)\end{array}$ & $\begin{array}{r}6.3 \\
(922)\end{array}$ & $\begin{array}{r}8.5 \\
(123)\end{array}$ & $\begin{array}{r}9.2 \\
(17450)\end{array}$ & $\begin{array}{r}6.9 \\
(125)\end{array}$ \\
\hline $70-105$ & $\begin{array}{r}6.4 \\
(532)\end{array}$ & $\begin{array}{r}7.2 \\
(589)\end{array}$ & $\begin{array}{r}9.7 \\
(1424)^{7}\end{array}$ & $\begin{array}{r}8.8 \\
(128)\end{array}$ & $\begin{array}{r}9.6 \\
(18250)\end{array}$ & $\begin{array}{r}9.7 \\
(175)\end{array}$ \\
\hline $05-140$ & $\begin{array}{r}7.5 \\
(623)\end{array}$ & $\begin{array}{r}8.3 \\
(573)\end{array}$ & $\begin{array}{r}11.2 \\
(1639)\end{array}$ & $\begin{array}{r}9.0 \\
(130)\end{array}$ & $\begin{array}{r}11.8 \\
(22425)\end{array}$ & $\begin{array}{l}11 . \\
(200\end{array}$ \\
\hline $40-175$ & $\begin{array}{r}14.8 \\
(1228)\end{array}$ & $\begin{array}{r}17.0 \\
(1169)\end{array}$ & $\begin{array}{r}11.5 \\
(1681)\end{array}$ & $\begin{array}{r}16.5 \\
(239)\end{array}$ & $\begin{array}{r}10.4 \\
(19650)\end{array}$ & $\begin{array}{r}9 . \\
(175\end{array}$ \\
\hline $75-210$ & $\begin{array}{r}10.7 \\
(894)\end{array}$ & $\begin{array}{l}12.7 \\
(876)\end{array}$ & $\begin{array}{r}6.4 \\
(932)\end{array}$ & $\begin{array}{l}6.1 \\
(88)\end{array}$ & $\begin{array}{r}10.7 \\
(20250)^{7}\end{array}$ & $\begin{array}{r}6.9 \\
(125)\end{array}$ \\
\hline $210-245$ & $\begin{array}{r}16.5 \\
(1370)\end{array}$ & $\begin{array}{r}17.2 \\
(1183)\end{array}$ & $\begin{array}{r}13.5 \\
(1998)\end{array}$ & $\begin{array}{r}9.5 \\
(137)\end{array}$ & $\begin{array}{r}13.3 \\
(25225)\end{array}$ & $\begin{array}{r}9 . \\
(175\end{array}$ \\
\hline $45-280$ & $\begin{array}{r}14.9 \\
(1238)\end{array}$ & $\begin{array}{r}9.3 \\
(640)\end{array}$ & $\begin{array}{r}10.2 \\
(1488)\end{array}$ & $\begin{array}{r}7.3 \\
(106)\end{array}$ & $\begin{array}{r}9.6 \\
(18125)\end{array}$ & $\begin{array}{r}5 . \\
(100\end{array}$ \\
\hline $280-315$ & $\begin{array}{r}11.2 \\
(928)\end{array}$ & $\begin{array}{r}7.8 \\
(539)\end{array}$ & $\begin{array}{r}9.1 \\
(1326)\end{array}$ & $\begin{array}{l}10.3 \\
(149)\end{array}$ & $\begin{array}{r}8.8 \\
(16675)\end{array}$ & $\begin{array}{r}18 . \\
(325\end{array}$ \\
\hline $315-350$ & $\begin{array}{r}6.9 \\
(577)\end{array}$ & $\begin{array}{r}4.4 \\
(302)\end{array}$ & $\begin{array}{r}9.1 \\
(1325)\end{array}$ & $\begin{array}{r}2.9 \\
(42)\end{array}$ & $\begin{array}{r}8.3 \\
(15675)\end{array}$ & $\begin{array}{r}15 \\
(275\end{array}$ \\
\hline & & & 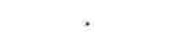 & & & \\
\hline OT AL & $\begin{array}{r}100 \\
(8319)\end{array}$ & $\begin{array}{r}100 \\
(6880)\end{array}$ & $\begin{array}{r}100 \\
(14632)\end{array}$ & $\begin{array}{r}100 \\
(1447)\end{array}$ & $\begin{array}{r}100 \\
(189400)\end{array}$ & $\begin{array}{r}1 \\
(18\end{array}$ \\
\hline
\end{tabular}

Actual figures in brackets 


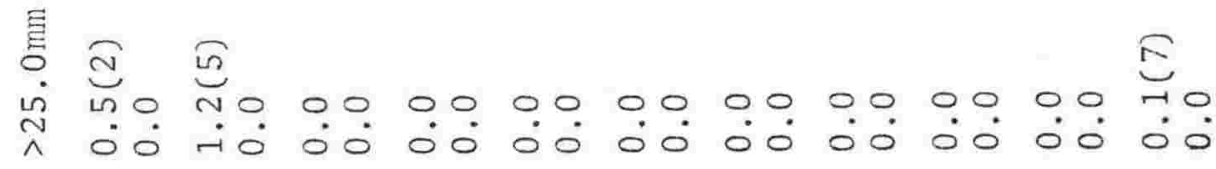

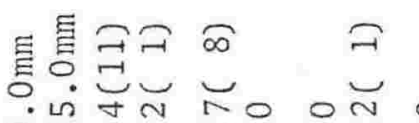

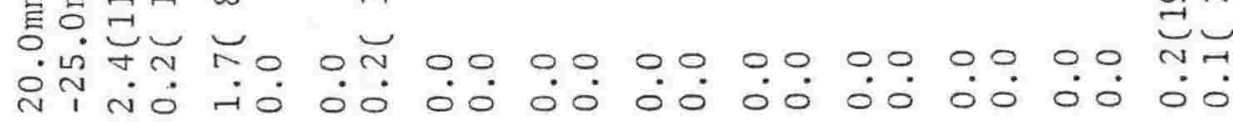

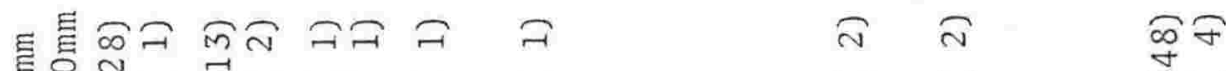

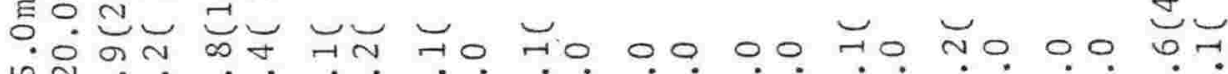

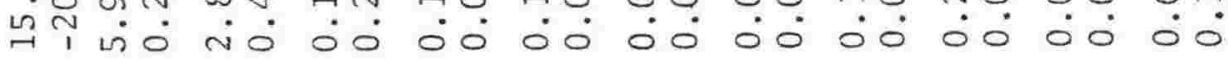

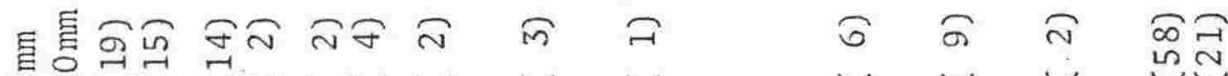

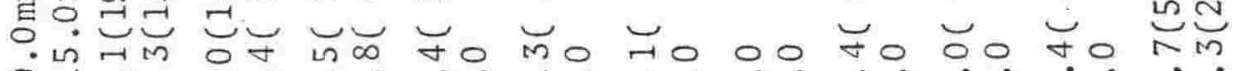

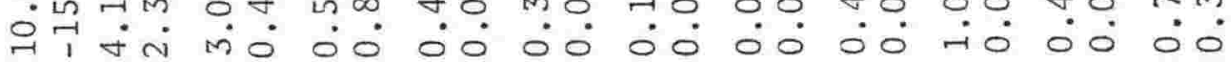

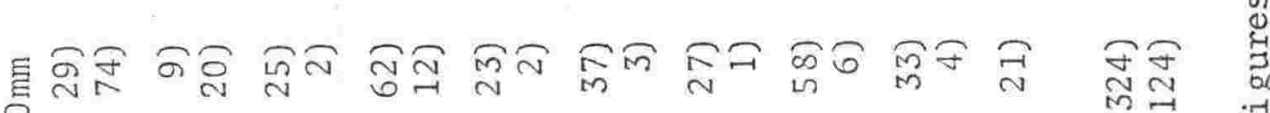

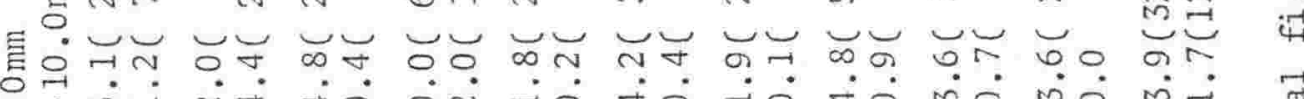

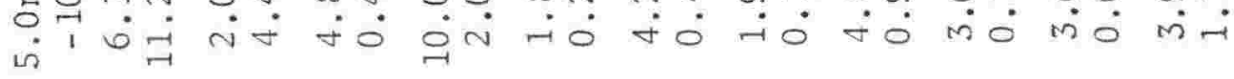

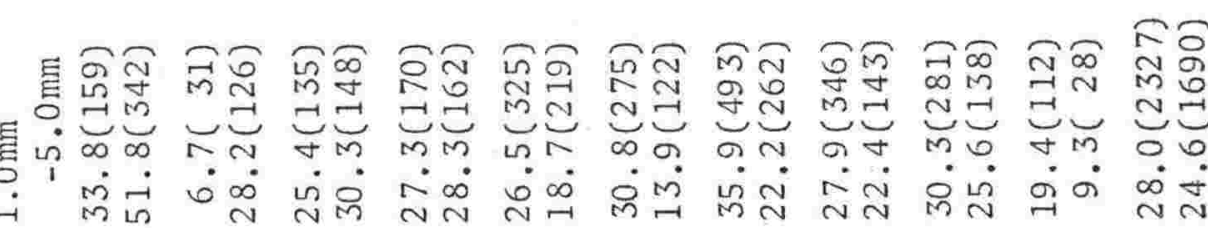

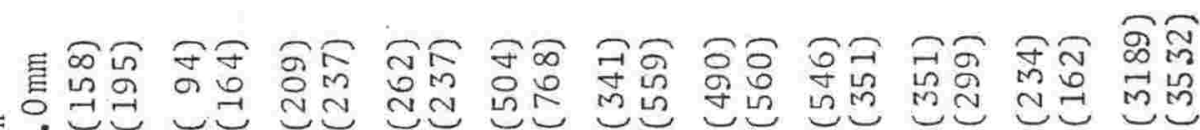

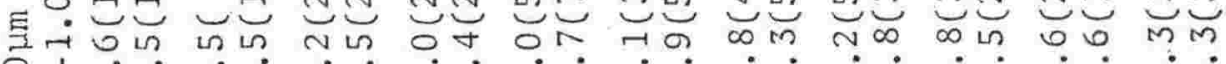

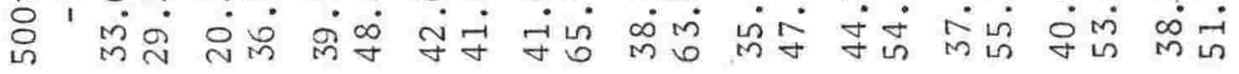

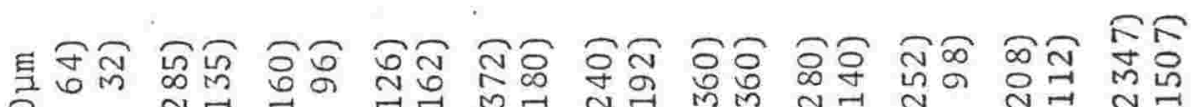

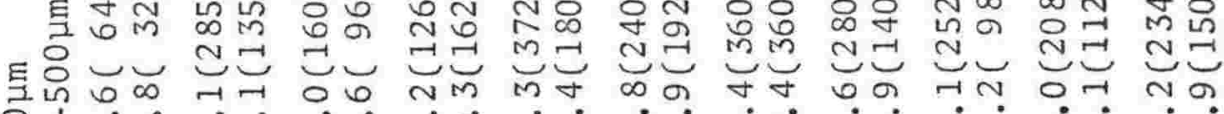
品 $\stackrel{9}{\dot{m}}$

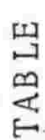

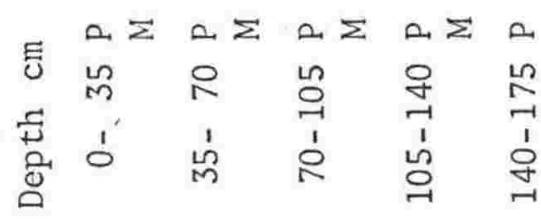

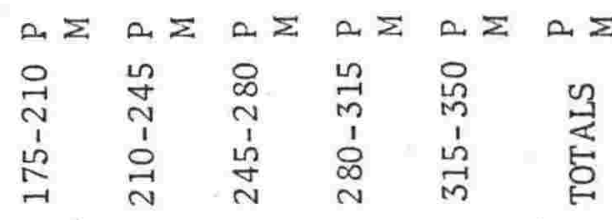


Size class distribution of Perna canaliculus at Elie Bay according to depth of water. 

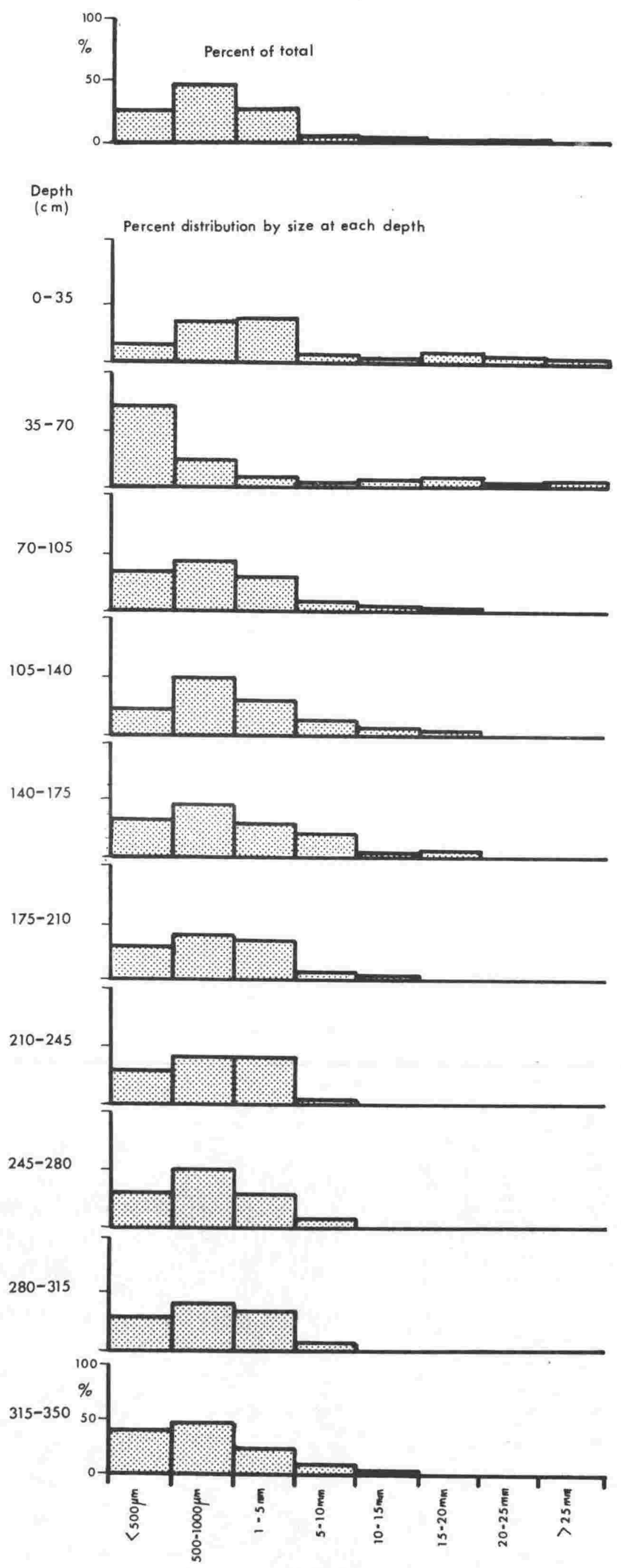
Ryenella reached its highest density (330 per collector) at the same level in the water column, but similar densities ( 310 per collector) were also recorded within $35 \mathrm{~cm}$ of the surface. Highest densities of Hiatella (50 per collector) were also recorded near the surface. Polychaetes reached their maximum density (50 per collector) between $280 \mathrm{~cm}$ and $315 \mathrm{~cm}$ from the surface. Tunicate colonies and barnacles which were considered as serious competitors on some other collectors, never exceeded $5 \%$ of the surface area and 10 individuals per collector respectively on the rubberised hair packing used in this experiment.

Settlement total in Waimaru Bay was comparable (15534) with that in Elie Bay and the proportion of the two species was also similar (see Table 3.10) but their distribution patterns were different. Perna had its second highest density within $35 \mathrm{~cm}$ of the surface and after a fall in numbers, recorded its maximum density (412 mussels per collector) at a depth of $70 \mathrm{~cm}$ to $105 \mathrm{~cm}$. Below this level a further decline in numbers was followed by another increase between $245 \mathrm{~cm}$ and $280 \mathrm{~cm}$ and then a decrease at the lowermost collectors. The distribution of Mytilus at this site was similar to that of Perna.

In Beatrix Bay where the total number of mussels was 4128, Mytilus was more numerous than Perna (see Table 3.10). The two species showed a similar pattern of 
TABle 3.10 COMParative SEttlement Against dePtH AT

THREE STATIONS

\begin{tabular}{|c|c|c|c|c|c|c|c|c|}
\hline \multirow[b]{2}{*}{ Depth $\mathrm{cm}$} & \multicolumn{2}{|c|}{ E LIE } & \multicolumn{2}{|c|}{ WAI MARU } & \multicolumn{2}{|c|}{ BEATRIX } & \multicolumn{2}{|c|}{ TOTALS } \\
\hline & $\mathrm{P}$ & M & $\mathrm{P}$ & M & $\mathrm{p}$ & M & P & M \\
\hline $0-35$ & $\begin{array}{r}5.7 \\
(470)\end{array}$ & $\begin{array}{r}9.6 \\
(660)\end{array}$ & $\begin{array}{r}18.7 \\
(1612)\end{array}$ & $\begin{array}{r}17.8 \\
(1230)\end{array}$ & $\begin{array}{c}11.3 \\
(186)\end{array}$ & $\begin{array}{c}15.2 \\
(377)\end{array}$ & $\begin{array}{r}11.9 \\
(2268)\end{array}$ & $\begin{array}{r}13.7 \\
(2267)\end{array}$ \\
\hline $35-70$ & $\begin{array}{r}5.5 \\
(459)\end{array}$ & $\begin{array}{r}6.5 \\
(449)\end{array}$ & $\begin{array}{r}4.5 \\
(387)\end{array}$ & $\begin{array}{r}4.9 \\
(340)\end{array}$ & $\begin{array}{r}6.2 \\
(103)\end{array}$ & $\begin{array}{r}6.5 \\
(161)\end{array}$ & $\begin{array}{r}4.9 \\
(949)\end{array}$ & $\begin{array}{r}5.7 \\
(950)\end{array}$ \\
\hline $70-105$ & $\begin{array}{r}6.4 \\
(532)\end{array}$ & $\begin{array}{r}7.2 \\
(489)\end{array}$ & $\begin{array}{r}28.6 \\
(2470)\end{array}$ & $\begin{array}{r}24.7 \\
(1706)\end{array}$ & $\begin{array}{c}4.1 \\
(67)\end{array}$ & $\begin{array}{r}5.9 \\
(147)\end{array}$ & $\begin{array}{r}16.2 \\
(3069)\end{array}$ & $\begin{array}{r}14.1 \\
(2342)\end{array}$ \\
\hline $105-140$ & $\begin{array}{r}7.5 \\
(623)\end{array}$ & $\begin{array}{r}8.3 \\
(573)\end{array}$ & $\begin{array}{r}8.5 \\
(731)\end{array}$ & $\begin{array}{r}12.4 \\
(856)\end{array}$ & $\begin{array}{r}7.4 \\
(123)\end{array}$ & $\begin{array}{r}5.5 \\
(135)\end{array}$ & $\begin{array}{r}7.8 \\
(1477)\end{array}$ & $\begin{array}{r}9.5 \\
(1564)\end{array}$ \\
\hline $140-175$ & $\begin{array}{r}14.8 \\
(1228)\end{array}$ & $\begin{array}{r}17.0 \\
(1169)\end{array}$ & $\begin{array}{r}5.9 \\
(510)\end{array}$ & $\begin{array}{r}6.5 \\
(450)\end{array}$ & $\begin{array}{r}10.0 \\
(166)\end{array}$ & $\begin{array}{r}7.2 \\
(178)\end{array}$ & $\begin{array}{r}10.0 \\
(1904)\end{array}$ & $\begin{array}{c}10.8 \\
(1797)\end{array}$ \\
\hline $175-210$ & $\begin{array}{l}10.7 \\
(894)\end{array}$ & $\begin{array}{c}12.7 \\
(876)\end{array}$ & $\begin{array}{r}4.2 \\
(359)\end{array}$ & $\begin{array}{c}9.8 \\
(676)\end{array}$ & $\begin{array}{r}10.2 \\
(169)\end{array}$ & $\begin{array}{r}10.2 \\
(252)\end{array}$ & $\begin{array}{r}7.5 \\
(1422)\end{array}$ & $\begin{array}{r}10.9 \\
(1804)\end{array}$ \\
\hline $210-245$ & $\begin{array}{r}16.5 \\
(1370)\end{array}$ & $\begin{array}{r}17.2 \\
(1183)\end{array}$ & $\begin{array}{r}7.2 \\
(625)\end{array}$ & $\begin{array}{c}5.9 \\
(407)\end{array}$ & $\begin{array}{c}11.3 \\
(186)\end{array}$ & $\begin{array}{l}11.1 \\
(276)\end{array}$ & $\begin{array}{r}11.5 \\
(2181)\end{array}$ & $\begin{array}{r}11.2 \\
(1866)\end{array}$ \\
\hline $245-280$ & $\begin{array}{r}14.9 \\
(1238)\end{array}$ & $\begin{array}{r}9.3 \\
(640)\end{array}$ & $\begin{array}{r}14.1 \\
(1216)\end{array}$ & $\begin{array}{l}10.2 \\
(707)\end{array}$ & $\begin{array}{c}14.7 \\
(242)\end{array}$ & $\begin{array}{l}13.8 \\
(343)\end{array}$ & $\begin{array}{r}14.2 \\
(2696)\end{array}$ & $\begin{array}{r}10.2 \\
(1690)\end{array}$ \\
\hline $280-315$ & $\begin{array}{r}11.2 \\
(928)\end{array}$ & $\begin{array}{r}7.8 \\
(539)\end{array}$ & & 8 & $\begin{array}{r}10.5 \\
(174)\end{array}$ & $\begin{array}{r}11.1 \\
(274)\end{array}$ & $\begin{array}{r}9.6 \\
(1813)\end{array}$ & $\begin{array}{r}8.2 \\
(1354)\end{array}$ \\
\hline $315-350$ & $\begin{array}{r}6.9 \\
(577)\end{array}$ & $\begin{array}{r}4.4 \\
(302)\end{array}$ & (711) & & $\begin{array}{l}14.3 \\
(235)\end{array}$ & $\begin{array}{r}13.5 \\
(334)\end{array}$ & $\begin{array}{r}6.4 \\
(812)\end{array}$ & $\begin{array}{r}5.7 \\
(636)\end{array}$ \\
\hline TOTAI & $\begin{array}{r}100 \\
(8319)\end{array}$ & $\begin{array}{r}100 \\
(6880)\end{array}$ & $\begin{array}{r}100 \\
(8621)\end{array}$ & $\begin{array}{r}100 \\
(6913)\end{array}$ & $\begin{array}{r}100 \\
(1651)\end{array}$ & $\begin{array}{r}100 \\
(2477)\end{array}$ & $\begin{array}{r}100 \\
(18591)\end{array}$ & $\begin{array}{r}100 \\
(16270)\end{array}$ \\
\hline
\end{tabular}

$\mathrm{P}=$ Perna canaliculus

$\mathrm{M}=$ Mytilus edulis aoteanus

Actual figures in brackets 
distribution with a decrease in numbers over the upper $105 \mathrm{~cm}$ followed by an increase to a maximum density ( 242 for Perna, 343 for Mytilus) at $245 \mathrm{~cm}-280 \mathrm{~cm}$. Densities increased slightly below this level but rose again on the lowermost collectors to 235 perna and 334 Mytilus.

Greenway (1969b) found that settlement at Te Kouma Harbour was largely confined to the surface in spring. but the summex spatfall was more evenly distributed. Brunette (1970) recorded the opposite in Kenepuru Sound where there was a marked increase with depth during the early spatfall, but the autumn settlement was restricted to the upper $35 \mathrm{~cm}$. Greenway (1969b) suggested temperature as the probable cause of this behaviour while Brunette (1970) thought it could have been due to either light intensity or fouling. Both authors seem to overlook the possibility of selective predation and of competing organisms like colonial tunicates.

Results from the present study indicate that the settlement at selected depths is certainly not species dependent since at each of the three stations within the study area, Perna and Mytilus showed similar distribution patterns. However, as there was considerable difference between stations it appears that depth preference is dependent on locality. This would suggest that the causative factors are hydrology, predation, or competition. 
3.3.4 Analysis of Experimental Settlement Materials

A) Preliminary Experiments

The highest rated material in Table 3.11 was yellow polypropylene filaments, followed closely by black film and then white film. Coir and foam plastic were considered moderately successful, while sisal performed poorly.

i) White film scored highly on its strength and durability. It was not subject to too much silting neither was it fouled by colonial tunicates or barnacles. However, its catchability rates were the lowest and its retention of settled spat was poor.

ii) Coir twine rated highly on catchability and retention of spat but badly on susceptibility to fouling, strength and durability. It was the best spat collector but required careful timing with spatfall in order to prevent fouling. Its life in seawater was limited and this made it commercially unattractive.

iii) Foam plastic was the only non-fibrous material tested. Its solid structure accumulated silt and provided a substrate for filamentous algae which settled only on this material. Fouling by tunicates and barnacles was low but so was the catch and retention of mussels. It was not durable in seawater and would not have commercial application. 
TABLE 3.11 PRELIMINARY ASSESSMENT OF MATERIALS FOR MUSSEL FARMING

\begin{tabular}{|c|c|c|c|c|c|c|}
\hline & $\begin{array}{l}\text { WHITE } \\
\text { FILM }\end{array}$ & $\begin{array}{l}\text { COIR } \\
\text { TWINE }\end{array}$ & $\begin{array}{c}\text { FOAM } \\
\text { PLASTIC }\end{array}$ & $\begin{array}{l}\text { SISAL } \\
\text { TWINE }\end{array}$ & $\begin{array}{r}\text { BLACK } \\
\text { FILM }\end{array}$ & $\begin{array}{l}\text { YE LLON } \\
\text { FI LAMENTS }\end{array}$ \\
\hline Perna & $(<20)$ & $\begin{array}{c}5 \\
(80+)\end{array}$ & $\begin{array}{c}4 \\
(50-80)\end{array}$ & $\begin{array}{c}3 \\
(20-50)\end{array}$ & $\begin{array}{c}5 \\
(80+)\end{array}$ & $\begin{array}{c}4 \\
(50-80)\end{array}$ \\
\hline Mytilus & $\begin{array}{c}2 \\
(<20)\end{array}$ & $\begin{array}{c}5 \\
(80+)\end{array}$ & $\begin{array}{c}3 \\
(20-50)\end{array}$ & $\begin{array}{c}4 \\
(50-80)\end{array}$ & $\begin{array}{c}5 \\
(80+)\end{array}$ & $\begin{array}{c}4 \\
(50-80)\end{array}$ \\
\hline RETENTION & $\begin{array}{c}3 \\
(\mathrm{mod})\end{array}$ & $\begin{array}{c}5 \\
\text { (v. } \text { good) }\end{array}$ & $\begin{array}{c}2 \\
\text { (poor) }\end{array}$ & $\begin{array}{c}0 \\
\text { (ni } 1)\end{array}$ & $\begin{array}{c}5 \\
(v \cdot \text { good })\end{array}$ & $\begin{array}{c}2 \\
\text { (poor) }\end{array}$ \\
\hline GRADING/ 15 & 7 & 15 & 9 & 7 & 15 & 10 \\
\hline Ryenella & $\begin{array}{c}3 \\
(20-50)\end{array}$ & $\begin{array}{c}1 \\
(80+)\end{array}$ & $\begin{array}{c}4 \\
(<20)\end{array}$ & $\begin{array}{c}2 \\
(50-80)\end{array}$ & $\begin{array}{c}1 \\
(80+)\end{array}$ & $\begin{array}{c}2 \\
(50-80)\end{array}$ \\
\hline Tumicates & $\begin{array}{c}4 \\
(<25 \%)\end{array}$ & $\begin{array}{c}2 \\
(50-75 \%)\end{array}$ & $\begin{array}{c}3 \\
(25-50 \%)\end{array}$ & $\begin{array}{c}3 \\
(25-50 \%)\end{array}$ & $\begin{array}{c}4 \\
(<25 \%)\end{array}$ & $\begin{array}{c}5 \\
(\mathrm{ni} 1)\end{array}$ \\
\hline$\neg$ Amphipods & $\begin{array}{c}3 \\
(35-70)\end{array}$ & $\begin{array}{c}1 \\
(100+)\end{array}$ & $\begin{array}{c}2 \\
(70-100)\end{array}$ & $\begin{array}{c}1 \\
(100+)\end{array}$ & $\begin{array}{c}2 \\
(70-100)\end{array}$ & $\begin{array}{c}4 \\
(<35)\end{array}$ \\
\hline o Barnacles & $\begin{array}{c}4 \\
(<5)\end{array}$ & $\begin{array}{c}3 \\
(5-15)\end{array}$ & $\begin{array}{c}5 \\
\text { (ni 1) }\end{array}$ & $\begin{array}{c}1 \\
(25+)\end{array}$ & $\begin{array}{c}4 \\
(<5)\end{array}$ & $\begin{array}{c}5 \\
(\mathrm{ni} 1)\end{array}$ \\
\hline Polychaetes & $\begin{array}{c}4 \\
(<5)\end{array}$ & $\begin{array}{c}2 \\
(10-15)\end{array}$ & $\begin{array}{c}5 \\
\text { (ni } 1)\end{array}$ & $\begin{array}{c}2 \\
(10-15)\end{array}$ & $\begin{array}{c}2 \\
(10-15)\end{array}$ & $\begin{array}{c}4 \\
(<5)\end{array}$ \\
\hline Silt & 4 & 3 & 1 & 4 & 4 & 5 \\
\hline GRADING/ 30 & 22 & 12 & 20 & 13 & 17 & 25 \\
\hline STRENGTH & $\begin{array}{c}5 \\
(\mathrm{ca} 225 \mathrm{~kg})\end{array}$ & $\begin{array}{c}2 \\
(\mathrm{ca} 60 \mathrm{~kg})\end{array}$ & $\begin{array}{c}1 \\
(<10 \mathrm{~kg})\end{array}$ & $\begin{array}{c}3 \\
(\mathrm{ca} 100 \mathrm{~kg})\end{array}$ & $\begin{array}{c}5 \\
(\mathrm{ca} 225 \mathrm{~kg})\end{array}$ & $\begin{array}{c}5 \\
(\mathrm{ca} 225 \mathrm{~kg})\end{array}$ \\
\hline DURABI LITY & $\begin{array}{c}5 \\
\text { (5yearst) }\end{array}$ & $\begin{array}{c}2 \\
\text { (15months) }\end{array}$ & $\begin{array}{c}1 \\
\text { (10months) }\end{array}$ & $\begin{array}{c}0 \\
\text { (2months) }\end{array}$ & $\begin{array}{c}5 \\
\text { (5years+) }\end{array}$ & $\begin{array}{c}5 \\
(5 y e a r s+)\end{array}$ \\
\hline $\begin{array}{l}\text { FINAL } \\
\text { GRADING /55 }\end{array}$ & 39 & 31 & 31 & 21 & 42 & 45 \\
\hline
\end{tabular}

\section{3}


iv) Sisal twine rotted within two months in seawater. While it seemed to resist silting, it was attractive to fouling organisms and of low strength. These disadvantages make it impossible to use in mussel farming operations.

v) Black film scored highly on the total count although not as high as the yellow filaments. However, unlike the yellow filements, it was extremely successful in attracting mussel spat and retaining its catch. It also scored highly on strength and durability. It deterred settlement of tunicates and barnacles and was not subjected to too much silting. It was attractive to Ryenella, amphipods and polychaetes. Although its total score was lower than that for yellow filaments it was considered superior to it for mussel farming.

vi) Yellow filaments rated high on strength, durability and resistance to silting. It was not fouled by colonial tunicates or barnacles and only a few amphipods were found on it. However, it was not very attractive to mussel larvae and those that did settle were not retained well. While scoring high on a total count, it failed in the important catchability and retention ratings.

\section{B) Successful Collectors}

The total number of mussels to settle at Elie, Waimaru and Beatrix Bays on the short term collectors was 4958 of which 1459 were Perna and 3499 Mytilus. Of this total 
$48.4 \%$ settled on coir rope, $32.9 \%$ on black film, and $18.6 \%$ on black rope. Perna settled most on the black film (41.9\%), while Mytilus was attracted mainly by the coir rope $(56.6 \%$ ) (see Table 3.12).

The long term collectors collected a total of 4056 mussels, 2557 of which were Perna and 1499 Mytilus. Pema was found predominantly on coir rope (42.1\%) while Mytilus seemed to prefer the black film (37.6\%). When both species were taken together coir rope was the most successful. It attracted $39.0 \%$ of the mussels settled throughout the experiment, the black film caught $34.9 \%$ and the black rope $26.1 \%$

The above are cumulative totals of collectors from Elie, Waimaru and Beatrix Bays. There were considerable differences in the performance of the two best collectors (coir and black film) at different localities. Table 3.13 shows coir rope to have been more successful than the black film with perna at Elie Bay (782 mussels against 554), but at Waimaru and Beatrix Bays the same species prefered the black film. Mytilus settled at nearly equal densities (411 and 494) on both collectors at Elie Bay and showed a slight preference for black film at Beatrix Bay, but decidedly favoured coir rope at Waimaru Bay: (1359 against 254). This marked preference for coir rope at waimaru Bay was caused by an unusual settlement of 1031 Mytilus on a single collector ( $10 \mathrm{~cm}$ long) during a period of 30 days from 27 september 1973. The same collector had three 
TABLE 3.12 PERCENTAge SETtLement AND SURVIVAL ON THREE SUCCESSFUL MATERIALS *

\begin{tabular}{|c|c|c|c|c|c|c|}
\hline & & & $\begin{array}{l}\text { COIR } \\
\text { ROPE }\end{array}$ & $\begin{array}{r}\text { B LACK } \\
\text { ROPE }\end{array}$ & $\begin{array}{r}\text { B LACK } \\
\text { FI LM }\end{array}$ & TOTAL \\
\hline$<$ & SHORT & TE RM & $\begin{array}{l}28.86 \\
(421)\end{array}$ & $\begin{array}{l}29.26 \\
(427)\end{array}$ & $\begin{array}{l}41.88 \\
(611)\end{array}$ & $\begin{array}{c}100 \\
(1459)\end{array}$ \\
\hline щ & LONG & TERM & $\begin{array}{c}42.08 \\
(1081)\end{array}$ & $\begin{array}{l}24.57 \\
(627)\end{array}$ & $\begin{array}{l}33.35 \\
(849)\end{array}$ & $\begin{array}{c}100 \\
(2557)\end{array}$ \\
\hline a & GAIN & / LOSS & $\begin{array}{l}+156.8 \\
(+660)\end{array}$ & $\begin{array}{l}+46.8 \\
(+200)\end{array}$ & $\begin{array}{r}+38.9 \\
(+238)\end{array}$ & $\begin{array}{r}+75.2 \\
(+1098)\end{array}$ \\
\hline $\begin{array}{l}n \\
D \\
\omega\end{array}$ & SHORT & TE RM & $\begin{array}{r}56.62 \\
(1981)\end{array}$ & $\begin{array}{l}14.17 \\
(496)\end{array}$ & $\begin{array}{r}29.21 \\
(1022)\end{array}$ & $\begin{array}{c}100 \\
(3499)\end{array}$ \\
\hline$\mapsto$ & LONG & TERM & $\begin{array}{l}33.82 \\
(501)\end{array}$ & $\begin{array}{l}28.62 \\
(429)\end{array}$ & $\begin{array}{l}37.56 \\
(562)\end{array}$ & $\begin{array}{c}100 \\
(1499)\end{array}$ \\
\hline $\begin{array}{l}> \\
\Sigma\end{array}$ & GAIN & / LOSS & $\begin{array}{r}-74.7 \\
(-1480)\end{array}$ & $\begin{array}{l}-13.5 \\
(-67)\end{array}$ & $\begin{array}{c}-44.9 \\
(-460)\end{array}$ & $\begin{array}{r}-57.3 \\
(-2007)\end{array}$ \\
\hline$\omega$ & SHORT & TERM & $\begin{array}{r}48.45 \\
(2402)\end{array}$ & $\begin{array}{l}18.62 \\
(923)\end{array}$ & $\begin{array}{r}32.93 \\
(1633)\end{array}$ & $\begin{array}{c}100 \\
(4958)\end{array}$ \\
\hline$\ll$ & LONG & TERM & $\begin{array}{r}39.03 \\
(1582)\end{array}$ & $\begin{array}{r}26.07 \\
(1056)\end{array}$ & $\begin{array}{r}34.90 \\
(1411)\end{array}$ & $\begin{array}{c}100 \\
(4056)\end{array}$ \\
\hline 0 & GAIN & /LOSS & $(-34.2$ & $\begin{array}{r}+14.4 \\
(+133)\end{array}$ & $\begin{array}{l}-13.4 \\
(-219)\end{array}$ & $\left(\begin{array}{l}-18.1 \\
(-902)\end{array}\right.$ \\
\hline
\end{tabular}

* Cumulative totals from Waimaru, Elie and Beatrix Bays 


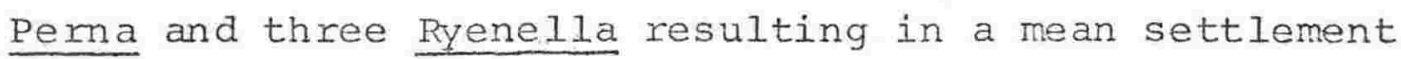
density of 16.52 larvae/ $\mathrm{cm}^{2}$.

TABLE 3.13 COMPARATIVE SETTLEMENT AT DIFFERENT STATIONS

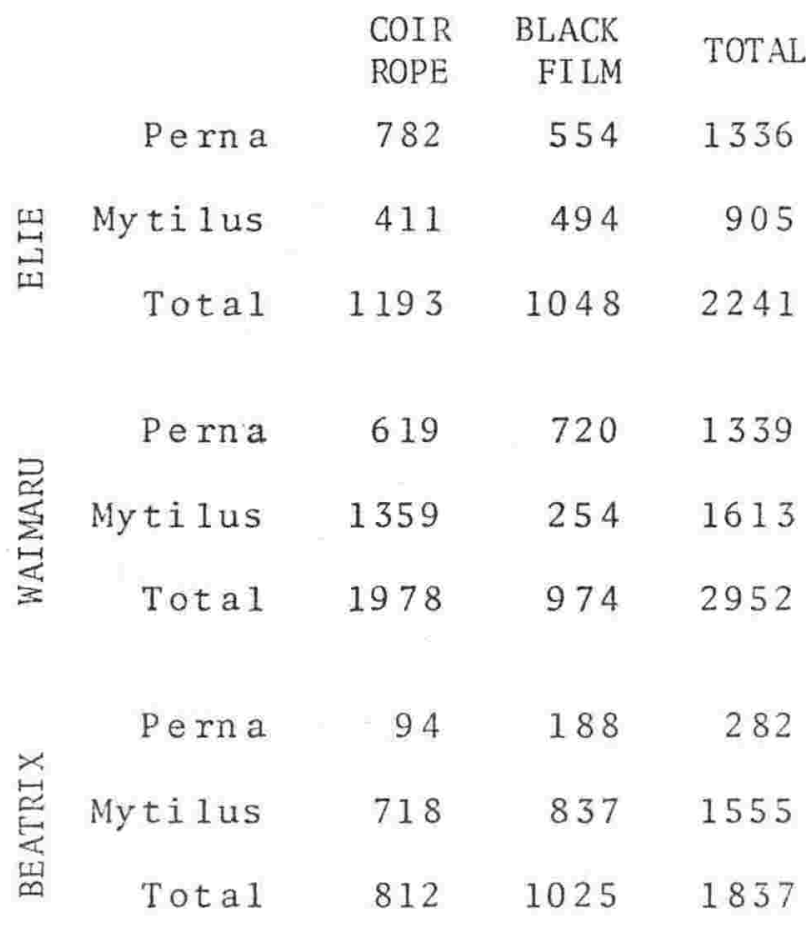

Mussel larvae on all long term coir and black film collectors from all three stations were divided into eight size classes. Table 3.14 shows that black film had a higher percentage of the three smaller size groups: $28.2 \%$ against $21.0 \%$; $19.5 \%$ against $15.1 \% ; 7.8 \%$ against 5.5\%. Coir rope carried more of the larger mussels : $35.6 \%$ against $29.2 \% ; 9.2 \%$ against $2.3 \% ; 2.8 \%$ against 1.5\%; with the exception of the $15-20 \mathrm{~mm}$ group which was more abundant on the black film (2.8\% against $2.0 \%$ )

Long term rope samples from Elie Bay were examined for 
TABLE 3.14 ANALYSIS OF SETTLEMENT ON TWO COLLECTORS

$$
\text { ACCORDING TO SIZE* }
$$

\begin{tabular}{|c|c|c|c|c|c|c|}
\hline & & I R ROPE & & B L & ACK FILM & \\
\hline & $\mathrm{p}$ & M & Total & P & M & Total \\
\hline $\begin{array}{l}250 \\
-500 \mu \mathrm{m}\end{array}$ & $25.9(280)$ & $10.4(52)$ & $21.0(332)$ & $33.8(287)$ & $19.4(109)$ & $28.2(396)$ \\
\hline $\begin{array}{l}500 \\
-850 \mu \mathrm{m}\end{array}$ & $17.2(186)$ & $10.6(53)$ & $15.1(239)$ & $23.3(198)$ & $14.5(82)$ & $19.5(274)$ \\
\hline $\begin{array}{l}850 \mu \mathrm{m} \\
-1.0 \mathrm{~mm}\end{array}$ & $5.2(56)$ & $6.2(31)$ & $5.5(87)$ & $6.6(55)$ & $10.0(56)$ & $7.8(111)$ \\
\hline $\begin{array}{l}1.0 \\
-5.0 \mathrm{~mm}\end{array}$ & $38.1(412)$ & $30.1(151)$ & $35.6(563)$ & $33.7(286)$ & $22.1(124)$ & $29.2(410)$ \\
\hline $\begin{array}{l}5.0 \\
-10.0 \mathrm{~mm}\end{array}$ & $7.4(80)$ & $13.0(65)$ & $9.2(145)$ & $0.9(8)$ & $4.3(24)$ & $2.3(32)$ \\
\hline $\begin{array}{l}10.0 \\
-15.0 \mathrm{~mm}\end{array}$ & $2.2(24)$ & $4.0(20)$ & $2.8(44)$ & $0.2(2)$ & $3.4(19)$ & $1.5(21)$ \\
\hline $\begin{array}{l}15.0 \\
-20.0 \mathrm{~mm}\end{array}$ & $1.3(14)$ & $3.6(18)$ & $2.0(32)$ & $0.1(\quad 1)$ & $6.8(38)$ & $2.8(39)$ \\
\hline$>20.0 \mathrm{~mm}$ & $2.7(29)$ & $22.1(111)$ & $8.8(140)$ & $1.4(12)$ & $19.5(110)$ & $8.7(122)$ \\
\hline TOTALS & 100 & 100 & 100 & 100 & 100 & 100 \\
\hline & (1081) & $(501)$ & (1582) & $(849)$ & $(562)$ & (1405) \\
\hline
\end{tabular}

*Cumulative totals from Elie, Waimaru and Beatrix Bays long term samples Actual figures in brackets 
organisms other than mussels and the results are given in Table 3.15. All fouling organisms except polychaetes settled predominantly on coir rope. This material attracted $54.7 \%$ of the barnacles, $34.6 \%$ of the amphipods and $42.9 \%$ of the Ryenella. Mean cover by colonial tunicates was $29.1 \%$ of its surface area. The black rope and black film were similar in their low numbers of barnacles (79 and 60) and amount of tunicate cover (9.7\% and 8.4\%). Amphipods on the black rope were $35.6 \%$ of total, Ryenella $33.7 \%$ and polychaetes 19.4\%. Black film was low in all fouling organisms except for polychaetes which settled best on this material (44.1\%) of the total.

The three collectors were graded comparatively on a three-point scale and the result is shown in Table 3.16. All three materials were good collectors of mussel spat and they all retained their catch. The two synthetic materials scored much higher than coir in their ability to resist fouling. They were also stronger and lasted longer in seawater. The collector with the best prospects for mussel farming was the black rope followed closely by the black film.

Mussels can make an active choice of setting place (Muus, 1973). They are known to be attracted to filamentous algae, Hydrozoa and other filamentous material (Coe 1932, Colman 1940, Harris 1946, Korringa 1951, Weiser 1952, 
茟

0

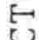

点

0

zo

zo

น

t

点

造

㟔

点

눈

a NMO

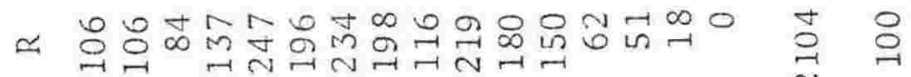

《

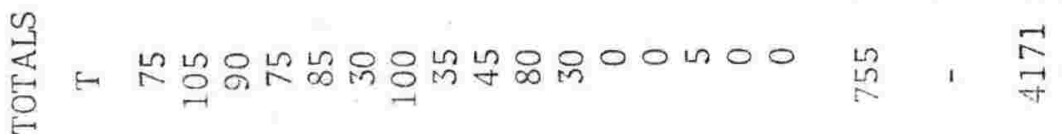

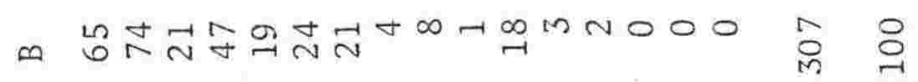

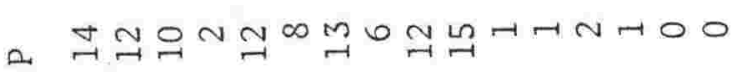

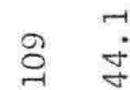

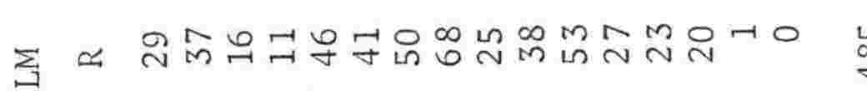

星

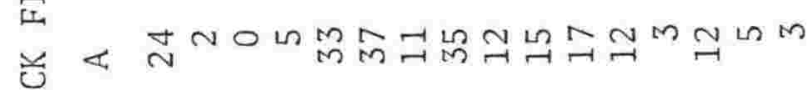

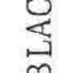

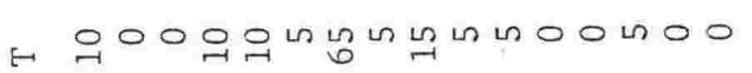

m $\forall$

$\ddot{\sim}$

$\infty$.

$\stackrel{\text { N }}{2}$

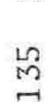

i.

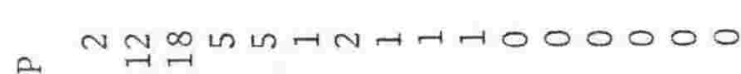

우

?

ค

$\infty$

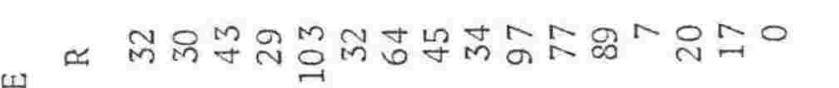

范

冚

< $4 M N \infty O \forall$ U

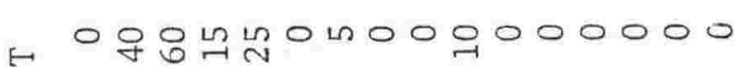

$+$

श

ir

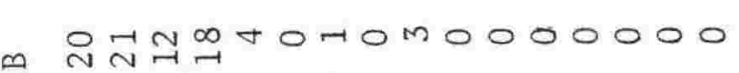

ก

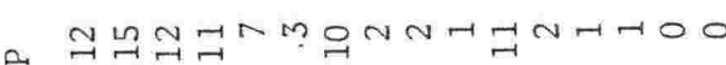

우

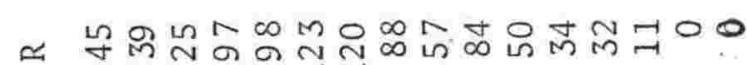

峞

《

옹

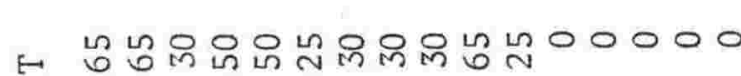

0
0
0
0
0
0
0
2
0
0

.

m

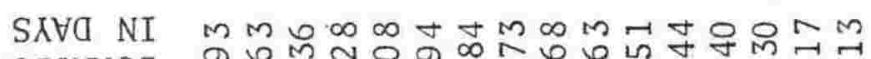

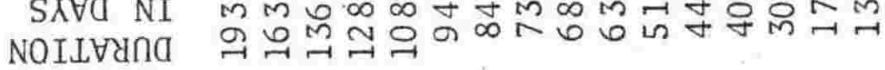

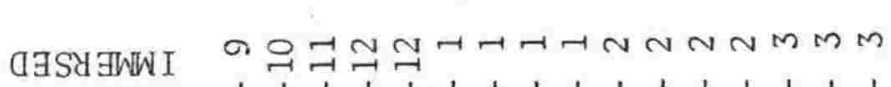


TABLE 3.16 GRADING OF SUCCESSFUL MATERIALS ACCORDING TO THEIR SUITABILITY FOR MUSSEL FARMING

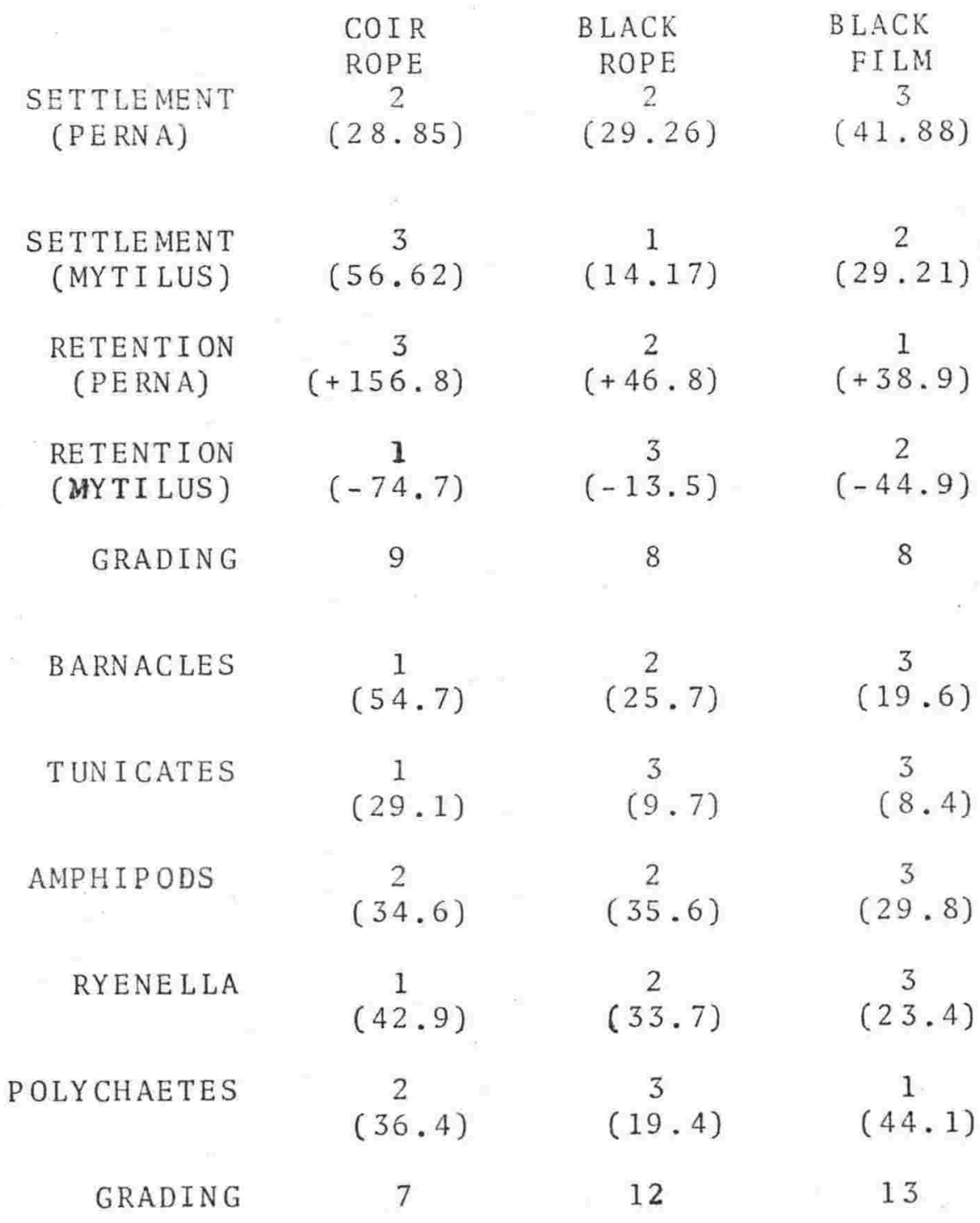

$\begin{array}{cccc}\text { STRENGTH } & 1 & 3 & 1 \\ & (\text { ca } 500 \mathrm{~kg}) & (\text { ca2030kg) } & (\text { calo00kg) } \\ \text { DURABILITY } & 1 & 3 & 2 \\ & \text { (15months) } & (5 \text { years }) & \text { (ca 5years) }\end{array}$

$\begin{array}{rlll}\text { FINAL } & \mathbf{1 8} & 26 & 26 \\ \text { GRADING } & \end{array}$

Upper figure in each case is the assigned grade, lower figure in brackets is a percentage settlement. 
Chipperfield 1953, Verwey 1954, De Blok \& Geelen 1958, Brienne 1960, Bayne 1964a, Lubet 1969, Seed 1969a, Le Gall 1970, Bohle 1971, Hrs-Brenko 1972, Hickman 1975). Seasoning of surfaces by epibionts is discussed elsewhere in this study and Perkins (1974) gives a list of reasons why bacteria and diatoms enhance settlement. However, Brunette (1970) obtained settlement of Perna on glass after only four days of immersion and De Blok \& Geelen (1958) maintain that general morphology of the collector is more important than chemical factors. Mussel larvae of different ages are known to seek different surfaces for settlement (De Blok \& Geelen 1958, Bayne 1964a), and according to Andreu (1968a) mussel larvae settle on collector ropes in spring but not in autumn, when they settle on rocks and other littoral structures.

The present study has shown a preference for materials which provided filaments and niches in the form of ramifications. Settlement was also observed on hydroid 'stems' (see Plate 3.10). There was also a marked preference for the darker of two otherwise identical collectors (polypropylene fibrillated film).

Although it is not known for certain why the black film should be so efficient in attracting mussel larvae examination by scanning electron microscopy showed that in the fibrillation process the black film tended to fray much more than the white film (Plate 3.11). This 
Perna canaliculus juveniles settled on hydroid 'stems'. 


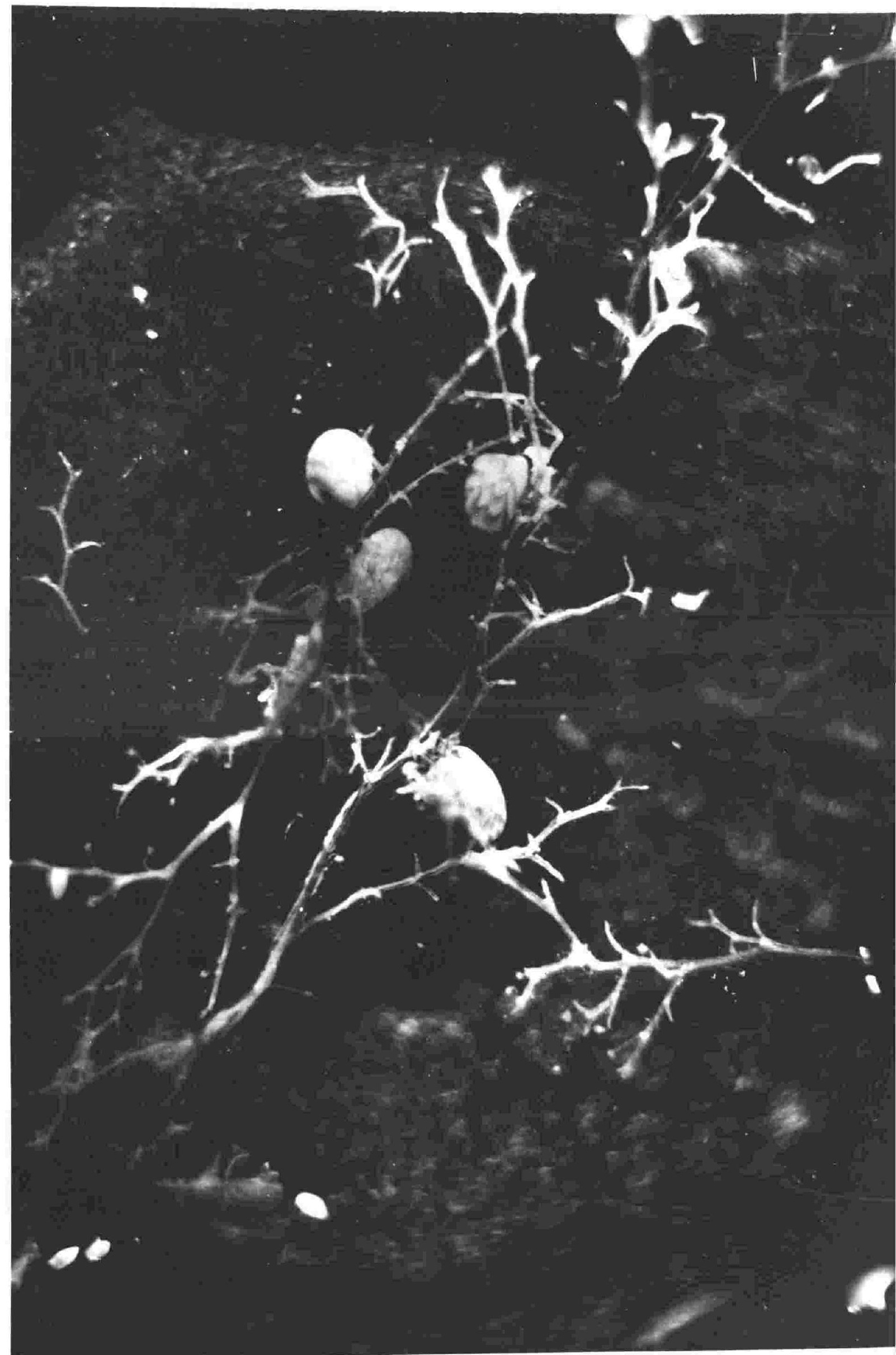


Scanning electron micrographs of three materials used as collectors of mussel spat.
A coir rope
B white polypropylene fibrillated film
C black polypropylene fibrillated film 
A
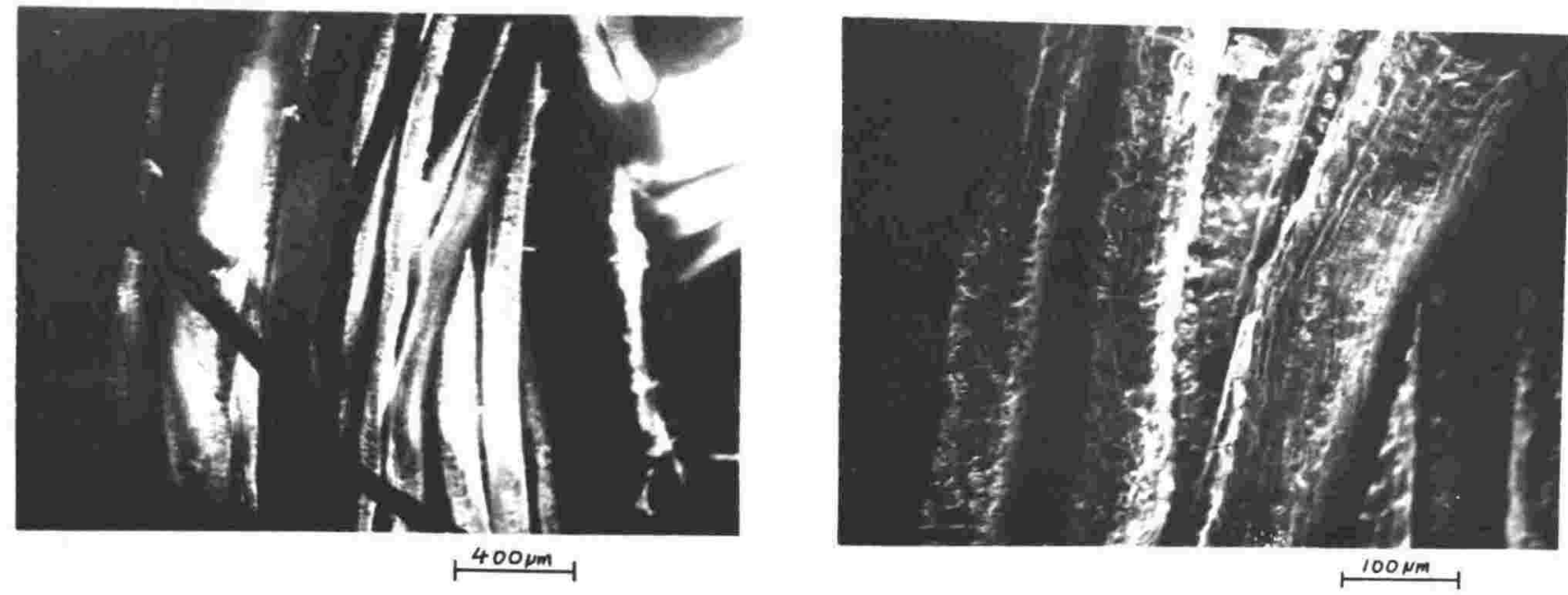

B
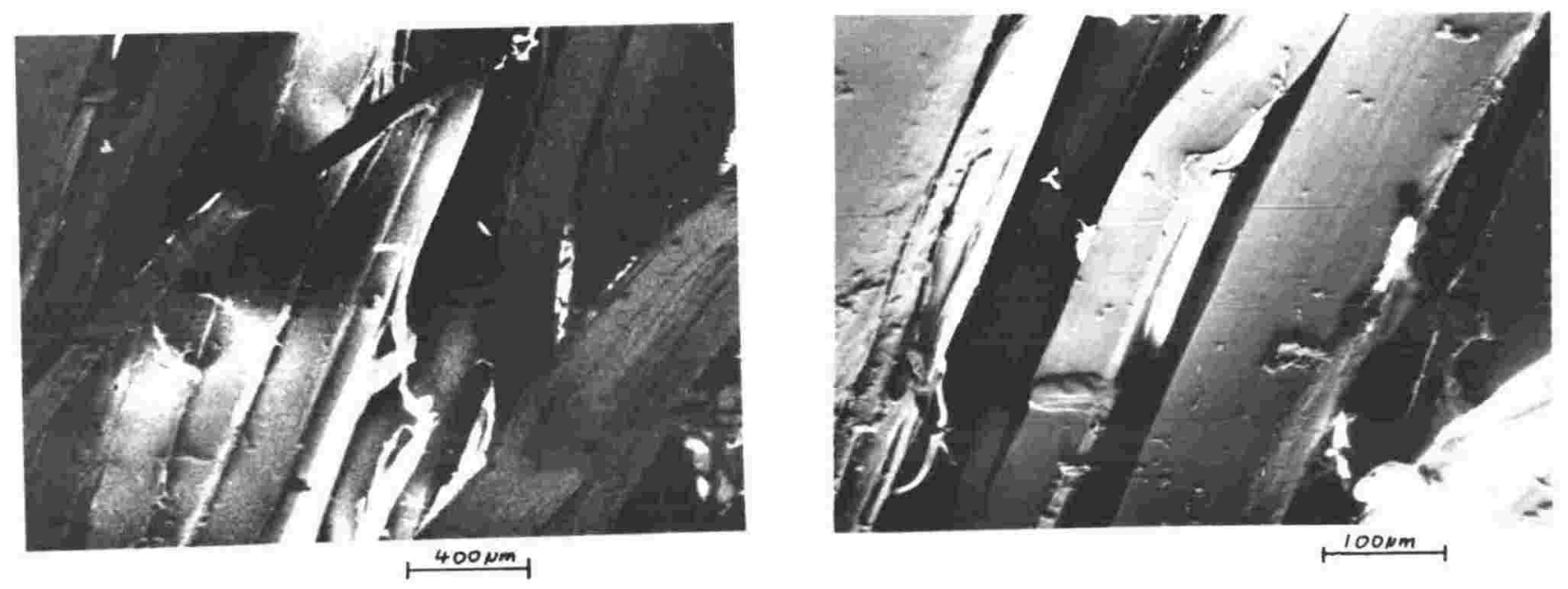

C
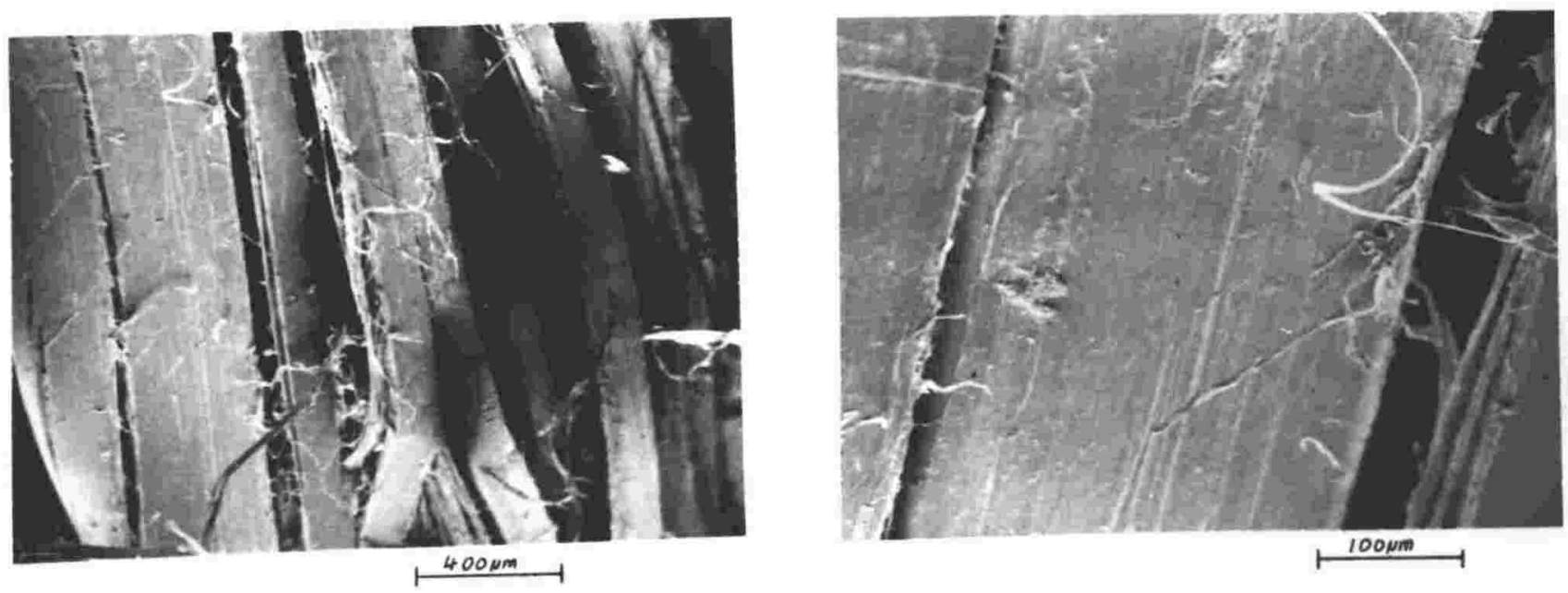
resulted in a surface covered in micrscopic 'hairs' that appeared to provide an effective substrate for the settlement of mussel larvae while inhibiting most competitors. Barnacles either did not settle at all, or when they did, they failed to survive. The spread of colonial tunicates, which usually smother newly settled mussels on ropes, was apparently slowed down by the fibrous nature of the fibrillated polypropylene film. By the time the tunicate colony started spreading the juvenile mussels were already established and of a size not affected by these competitors.

The fibrillated film is not strong enough by itself to sustain the weight of a crop of fully grown mussels. Therefore, short pieces of film were inserted into the lay of the black polypropylene rope (Plate 3.12 A) at $20 \mathrm{~cm}$ intervals. This combination of black polypropylene film rope and crosspieces of the same material, has proved highly successful as a collector of mussel spat. It required little or no seasoning in seawater before it collected mussel larvae, and the settlement of competing organisms was greatly reduced.

The use of crosspieces in the lay of the rope invariably led to clumping (Plate 3.12B). During these initial experiments the distance between crosspieces was $20 \mathrm{~cm}$. If this distance was to be reduced, settlement may well be continuous along the entire rope. The same combination is also being investigated in the Philippines (Tortell, 
A Black polypropylene film used as crosspieces in the lay of a rope of the same material.

B This combination was very successful in attracting mussels but it resulted in clumping. 


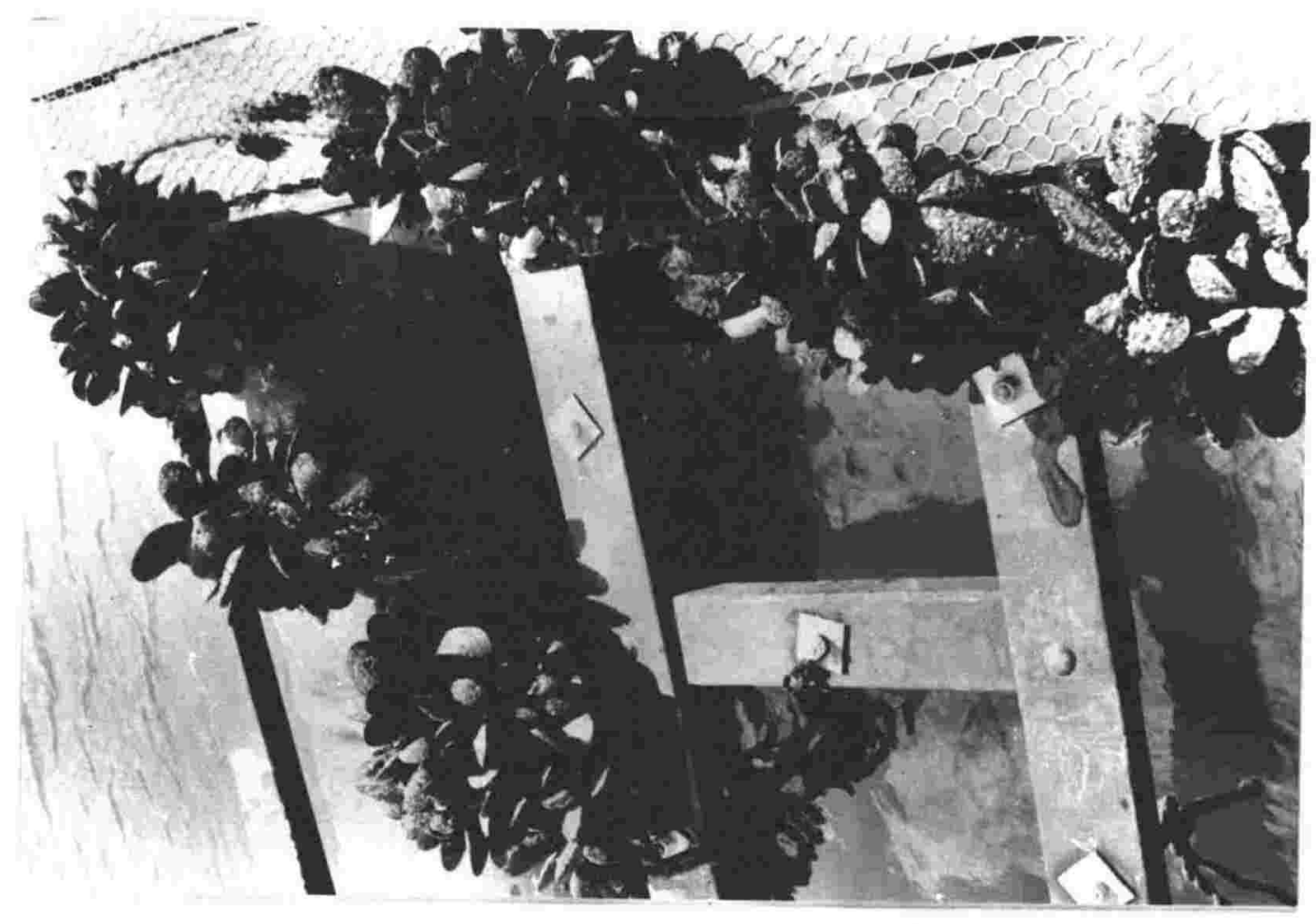

$\infty$

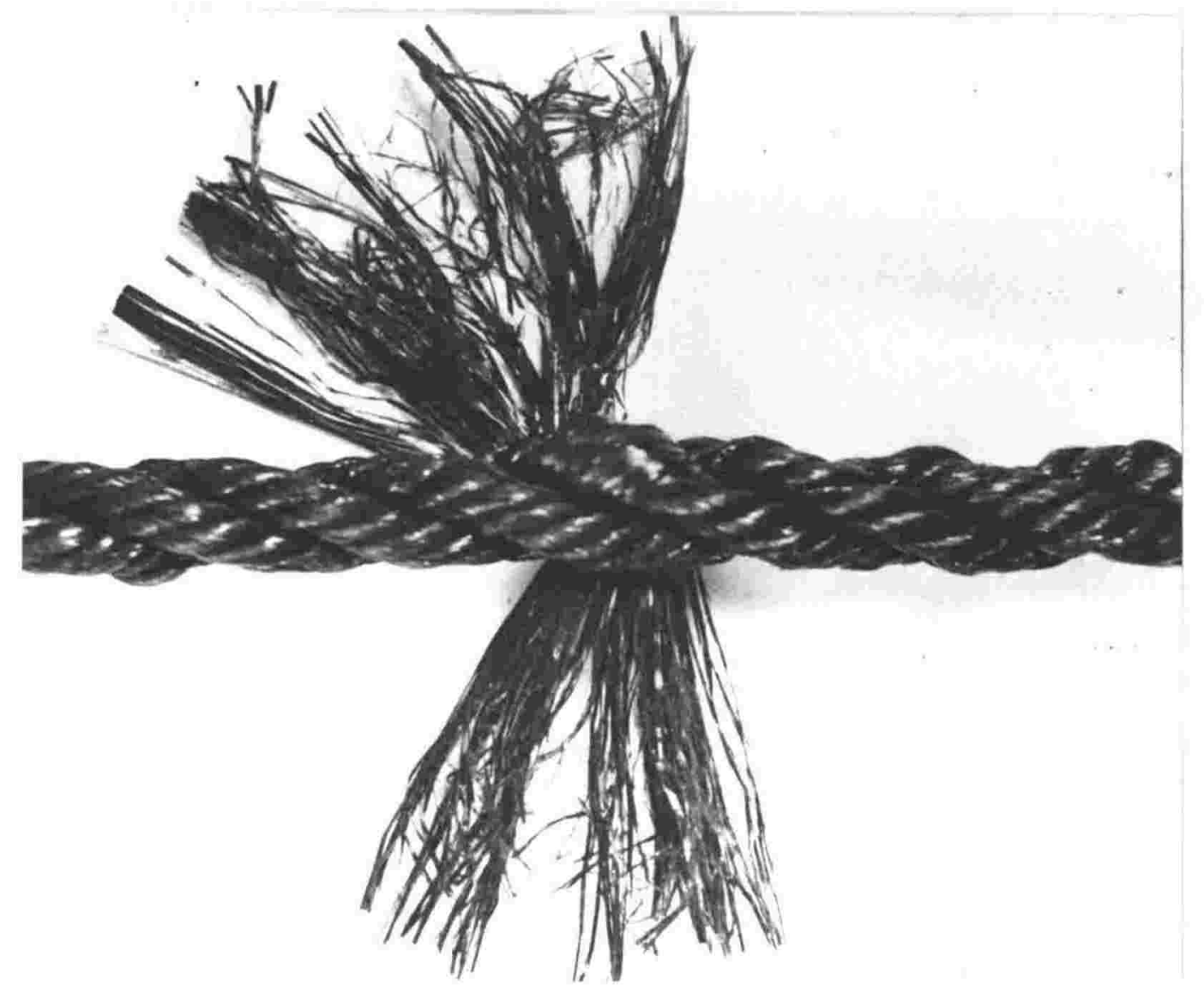

$<$ 
1975) where it may also be successful with Mytilus smaragdinus.

C) Fouling and Competitors

Fouling organisms may enhance or inhibit spatfall (Davies, 1974). A great deal of published material exists on the season of settlement and biotic succession of fouling communities in general (Coe 1932, Hewatt 1935, Scheer 1945, Woods Hole Oceanographic Institution 1952, Ralph \& Hurley 1952, Skerman 1958, 1959, 1960, Wisely 1959, Brunette 1970, Colgate 1971, Jones \& Eltringham 1971, Luckens 1970, 1975a, 1975b, 1976). While most of the work has been in relation to ship fouling, some authors have discussed fouling in the context of a marine farm (Miyazaki 1938, Andreu 1968a, Favretto 1968, Hrs-Brenko \& Igic 1968, Ryther 1968, Bardach et al 1972).

The most common fouling organisms encountered in this study were ascidians, barnacles, amphipods, and polychaetes. of these, the ascidians were the most serious due to their prolific breeding rate and their ability to smother newlysettled mussels (see also Wilson \& Hodgkin 1967, Anon 1974a). Although Miller (1971) maintains that ascidians exercise considerable choice in settlement and that they respond to the 'shadow reflex', Brunette (1970) states that they were not selective for substrate being "equally common on ropes, glass slides, and asbestos plates, .... 
just as common on the upper surface of plates as on the lower surface, ..... no preference for settlement at any light intensity". According to Ralph \& Hurley (1952) they spawn over many months with a settlement peak in spring and summer. In the study area the ascidians appeared in spring, flourished in summer and normally abated during autumn (see also Anon 1974a). They did not exhibit any preference for depth but they did settle best on natural materials. Their prolific advance was slowed down and possibly even inhibited by materials of a fibrous nature like rubberised hair packing and fibrillated polypropylene film.

Barnacles are known to seek rough surfaces in preference to smooth ones (Barnes, 1956), clean rather than fouled (Brunette, 1970) and darkness rather than light (Visscher 1928, Gregg 1945). Houghton \& Stubbings (1963) showed that optimum depth for Elminius modestus was between four and five metres. Barnacles also orient themselves along grooves (Crisp \& Barnes, 1954) and other surface contours, and this response is greater than their response to light (Houghton, 1971). In the present study barnacles selected sisal twine as the prime settlement material, followed by coir. The other materials (all synthetic) were either sparsely settled or not at all. There did not appear to be any prefered depth but there was. a preference for certain stations within the study area. Waimaru Bay had less barnacles than any of the other stations and this could be due to the swift water currents 
to which this area was occasionally subjected. Perkins (1974) considered a current of two knots as the limit for settlement for Elminius modestus. Although no direct current measurements are available it is thought that currencs of this speed were not uncommon at Waimaru Bay especially at the time of the equinoxial gales in spring and autumn.

Ryenella and Hiatella were the only bivalves commonly found on the ropes other than Perna and Mytilus. Although it settled in large numbers, Ryenella did not survive long on the ropes and is not thought to have provided any competition for the Perna and Mytilus juveniles. Hiatella settled at lesser densities and sought the inside of clumps. As such it did not compete with the commercial mussels for food and it took up very little space. Ryenella settled best on coir and black film and seemed capable of selecting the black film in preference to the white.

Amphipods are often not considered fouling organisms (Coe 1932, Weiss 1948, Ralph \& Hurley 1952, Luckens 1976). However, Brunette (1970) encountered them in Kenepuru sound throughout his study. They were also very abundant during the present study especially on coir and sisal. Of the synthetic materials they prefered the black film and settled least on the yellow filaments. Although they are not thought to constitute any direct 
competition for mussels, except possibly in using up potential settlement space, they are undesirable on the ropes since they are thought to attract predatory fish (Miyazaki, 1938).

Polychaetes also attract potential predators. However, the number of sedentary polychaetes was insignificant and only errant worms were taken into consideration in this study. These were attracted equally by coir and black film, but in neither case were they very numerous.

It was not possible to detect any depth preference by any of the important fouling and competing organisms down to $3.5 \mathrm{~m}$.

3.4 CONCLUSIONS

1. The reproductive cycle of perna canaliculus appears to be influenced by water temperature. When the temperature reaches $18 \pm 0.5^{\circ} \mathrm{C}$ in spring mussels are stimulated to spawn but a further rise in temperature inhibits this process. When the temperature falls to $18 \pm 0.5^{\circ} \mathrm{C}$ after the summer maxima mussels spawn once more and continue to do so until spent.

2. The duration of pelagic larval life has not been 
determined. Complex biological and physical factors acting on this phase can affect the survival rates and distribution so much as to make larval density inappropriate as an indicator of imminent spatfall except, perhaps, at times of maximal activity.

3. A peak in spawning need not be followed by a peak in the abundance of planktonic larvae and this does not necessarily lead to a peak in settlement. The latter is a function of larval survival and dispersal, as well as the presence of a suitable substrate.

4. A broad temporal relationship was found between spawning adults, pelagic larvae, environmental conditions and settlement of Perna in Elie Bay during the study period. However, a strict correlation between settlement and other phenomena cannot be attempted without daily records over a period of years and until this is achieved accurate and reliable spatfall prediction is not possible.

5. Black fibrillated polypropylene film is as attractive to mussel larvae as the more traditional coir rope. Also it is more resistant to fouling, comparatively stronger and lasts longer in seawater.

6. A rope manufactured out of the black film was not as attractive to mussel larvae as the film on its own while the film on its own could not support a crop of 
fully grown mussels. A combination of crosspieces of black polypropylene fibrillated film in the lay of a rope of the same material was extremely successful and appears to hold great potential as a new rope for mussel farming. 
I would like to thank the following people for help with the experimental rafts:- Messrs I.C.I. (N.Z.) Ltd. for Dulux Duretar paint, Messrs Caltex (N.Z.) Ltd. for the oil drums, Fisheries Research Division of the Ministry of Agriculture and Fisheries for the mooring chain, the Railways Department for rolling stock wheels used for moorings, and especially Mr G. Grainger who built the rafts and Capt. Jamison of the Marlborough Harbour Board who gave his permission for the siting of the rafts.

My thanks are also due to $\mathrm{Mr}$ R. Halliday who collected plankton samples regularly over a year and Mr M.F. Bull who helped with sampling and other ways throughout the extent of the study period. I am also grateful to $\mathrm{Mr}$ J. Jenkins of the Fishing Industry Board, Mr B. ChapmanCohen, Mr L. Batenberg and Mr J. Morrow for transport to and from the study area and kind hospitality. 
ALLEN, F.E. (1955) Identity of breeding temperatures in southern and northern species of Mytilus (Lamellibranchia). Pacific Science 9:107-109 ANDREU, B. (1960) Un parasito del mejillon : propagacion del copepodo parasito Mytilicola intestinalis en el mejillon de las rias bajas. Revista de economia de Galicia, Vigo, September/December 1960, pp 1-7

ANDREU, B. (1968a) Fishery and culture of mussels and oysters in spain. Proceedings of the Symposium on Mollusca Part III : 835-845

ANDREU, B. (1968b) The importance and possibilities of mussel culture. Working Paper 5 - Seminar on Possibilities and Problems of Fisheries Development in Southeast Asia. German Foundation for Developing Countries, Berlin. 15pp ANDREU, B. (1973) Perspectivas de la acuicultura marina en España. Informes Tecnicos del Instituto de Investigaciones Pesqueras 9, 47pp

ANON (1968) Raft cultivation of mussels is big business in Spain. World Fishing, March, 1968

ANON (1974a) Fouling problems beset mussel rafts. Fishing Industry Board Bulletin No.29:6

ANON (1974b) Bright outlook for rock oysters. Catch 74, $1(3): 5$ 
ANON (1975) Long line mussel farming shows promise.

Catch $75,2(4): 6-7$

AUDOIN, J. (1954) La mytiliculture en Baie de L'

Aiguilion. Science et Peche 1(16):7-10

BARDACH, J.E. et al (1972) Aquaculture, The Farming

and Husbandry of Freshwater and Marine Organisms

J. Wiley \& Sons Inc, New York, 868pp

BARNES, H. (1956) Surface roughness and the settlement

of Balanus balanoides I. Archives Societatis

Vanamo $10: 164-167$

BATTLE, H.I. (1932) Rhythmic sexual maturity and spawning

of certain bivalve mollusks. Contributions of the Fisheries Research Board of Canada 7:257-276

BAYNE, B.L. (1963) Responses of Mytilus edulis larvae to increases in hydrostatic pressure. Nature $198(4878): 406-407$

BAYNE, B.L. (1964a) Primary and secondary settlement in Mytilus edulis L. (Mollusca). Journal of Animal Ecology $33: 513-523$

BAYNE, B.L. (1964b) The responses of the larvae of Mytilus edulis I. to light and gravity. Oikos $15(1): 162-174$

BAYNE, B.L. (1965) Growth and delay of metamorphosis of the larvae of Mytilus edulis L. Ophelia 2(1): $1-47$

BERNER, L. (1935) La reproduction des moules comestibles (Mytilus edulis L. et Mytilus galloprovincialis Lmk.) et leur repartition geographique. Bulletin del' Institut Oceanographique, Monaco, No.680 
BOARD, P.A. \& COLLINS, T.M. (1965) Physical forces in marine fouling. Discovery, London 26(5):14-18

BØHLE, B. (1970) Fors $\varnothing k$ med dyrking av bläskjell (Mytilus edulis L.) ved overføring av yngel til nettingstrømper. Fiskerei Gang 56:267-271

BфHLE, B. (1971) Settlement of mussel larvae Mytilus edulis on suspended collectors in Norwegian waters. In Crisp, J. Fourth European Marine Biology Symposium, Cambridge University. 63-69

BoOTH, J.D. (1972) Studies on New Zealand bivalve larvae with observations on the adults and on the hydrology of Bay of Islands and Wellington Harbour. Unpublished Ph.D. Thesis, Victoria University of Wellington.

BOUXIN, H. (1956) Observations sur le frai de Mytilus edulis var. galloprovincialis (Lmk), dates precises de frai et facteurs provoquent l'emission de produits genitaux. Rapport Reunion du Conseil permanent international pour l'Exploration de la Mer $140(3): 43-46$

BRICK, R.W. (1970) Some aspects of raft culture of oysters

in Hawaii. Hawaii Institute of Marine Biology, Technical Reports, No24, mimeographed, 47pp BRIENNE, H. (1960) Mytilicola intestinalis steur, dans les moules de la baie de l'Aguillon. Science et Peche, Paris $87: 6$

BRUNETTE, R.N. (1970) Settlement of Marine Organisms in Kenepuru Sound. Unpiblished B.Sc. (Hons) Project Victoria University of Wellington 
CALABRESE, A. \& DAVIS, H.C. (1970) Tolerances and requirements of embryos and larvae of bivalve molluscs. Helgoländer wissenschaftliche Meeresuntersuchungen 20:553-564

CAMPBELL, J.S. (1971) Observations on Spanish mussel cultivation. Report on Mussel Cultivation Seminar, October 1971, Fishing Industry Board $: 4-6$

CARRIKER, M.R. (1951) Ecological observations on the distribution of oyster larvae in New Jersey estuaries. Ecological Monographs 21:19-38

CHANLEY, P. (1970) Larval development of the hooked mussel, Brachiodontes recurvus Rafinesque, (Bivalvia : Mytilidae) including a literature review of larval characteristics of the Mytilidae. Proceedings of the National Shellfisheries Association $60: 86-94$

CHIPPERFIELD, P.N.J. (1953) Observations on the breeding and settlement of Mytilus edulis (L.) in British waters. Journal of the Marine Biological Association, U.K. $32(2): 449-476$

COE, W.R. (1932) Season of attachment and rate of growth of sedentary marine organisms at the pier of the Scripps Institute of Oceanography, La Jolla, California. Bulletin, Scripps Institute of Oceanography $3: 37-86$

COLE, H.A. \& SAVAGE, R.E. (1971) The effect of the parasitic copepod Mytilicola intestinalis (Steuer) upon the condition of mussels. Parasitology $: 156-161$ 
COLGATE, D.G. (1971) The settlement of wharf-pile

organisms in Shelly Bay. Unpublished B.Sc. (Hons) Project, Victoria university of Wellington.

COLMAN, J. (1940) On faunas inhabiting intertidal

seaweeds. Journal of the Marine Biological

Association, U.K. 24:129-183

CRISP, D.J. \& BARNES, H. (1954) The orientation and distribution of barnacles at settlement with particular reference to surface contours. Journal of Animal Ecology 23:142-162

CURTIN, L. (1971a) Oyster farming in New Zealand. Marine Department Fisheries Technical Report no. 72

CURTIN, I. (1971a) Marine Department rock oyster spat catching programme 1969-1970. Marine Department Fisheries Technical Report no. 65

CURTIN, L. (1971C) Marine Department rock oyster spat catching programme 1970-1971. Marine Department Fisheries Technical Report no. 74

CURTIN, L. (1974) Rock oyster spat catching programme. Catch $74 \quad 1(11): 4$

DARE, P.J. \& DAVIES, G. (1975) Experimental suspended culture of mussels (Mytilus edulis L.) in Wales using spat transplanted from a distant ground. Aquaculture $6: 257-274$

DARE, P.J. \& EDWARDS, P.G. (1975) Seasonal changes in flesh weight and biochemical composition of mussels (Mytilus edulis L.) in the Conwy Estuary North Wales. Journal of Experimental Marine Biology and Ecology 18:89-97 
DAVIES, G. (1974) A method for monitoring the spatfall of mussels (Mytilus edulis L.). Journal du Conseil International pour l'Exploration de Ia Mer. $36(1): 27-34$

DAYTON, P.K. (1971) Competition, disturbance and community organisation : the provision and subsequent utilization of space in a rocky intertidal commity. Ecological Monographs $41(4): 351-389$

DE BLOK, J.W. \& GEELEN, H.J.F.M. (1958) The substratum required for the settling of mussels (Mytilus edulis I.). Archives Neerlandaises Zoologie $13: 446-460$

DURVE, D.S. (1965) On the seasonal gonadal changes and spawning in the adult oyster (Crassostrea gryphoides Schlotheim). Journal of the Marine Biological Association of India 7(2):328-344 ELLIOTT, J.M. (1973) Some methods for the statistical analysis of samples of benthic invertebrates. Freshwater Biological Association, Scientific Publication no. $25 \quad 148 \mathrm{pp}$

FAUVEL, Y. (1954) Methodes d'elevage des moules et huitres dans I'etang de Thau. F.A.O. General Fisheries Council for the Mediterranean, Proceedings and Technical Papers no.2:340-341 FAVRETTO, L. (1968) Aspetti merceologici della mitilicoltura nel Golfo di Trieste. Bollettino della Societa Adriatica di Scienze, Trieste 66(2): 243-261 
FIELD, A.I. (1922) Biology and economic value of the sea mussel Mytilus edulis. Bulletin of the U.S. Bureau of Fisheries 38:127-259

FIGUERAS, A. (1976) Desarrollo actual del cultivo del mejillon (1ytilus edulis L.) y posibilidades de expansion. F.A.O. Technical Conference on Aquaculture, Kyoto, Japan, 1976, Document FIR:AQ/Conf/76/r. 7

FLAWS, D.E.F. (1968) Observations on the ecology of Mytilidae and Thaisidae in Wellington Harbour. Unpublished B.Sc.(Hons) Project, Victoria University of Wellington.

FLAWS, D.E.F. (1968) Aspects of the biology of mussels in the cook Strait area. Unpublished Ph.D. Thesis, Victoria University of Wellington $219 \mathrm{pp}$

GIESE, A.C. (1959) Comparative physiology : annual reproductive cycles of marine invertebrates. Annual Reviews of Physiology 21:547-576

GRAHAM, G,W. \& GAY, H. (1945) Season of attachment and growth of sedentary organisms at oakland, California. Ecology 24(2):375-385

GREENWAY, J.P.C. (1969a) The monitoring of rock oyster settlement at Mahurangi, Auckland, 1968-9. Marine Department Fisheries Technical Report no. 48 
GREENWAY, J.P.C. (1969b) Settlement and growth of a colony of the large green mussel from a pontoon in Te Kouma Harbour, Coromandel. Marine Department Fisheries Technical Report no. 43

GREENIAY, J.P.C. (1971) Rock oyster (Crassostrea glomerata) spat collecting on an exposed beach at Mahurangi heads near Auckland. Marine Department Fisheries Technical Report no.71

GREGG, J.H. (1945) Background illumination as a factor in the attachment of barnacle cyprids. Biological Bulletin, Woods Hole 88:44-49

HANCOCK, D.A. (1960) The ecology of the molluscan enemies of the edible molluscs. Proceedings of the Malacological Society of London $34(3): 123-143$

HARRIS, J.E. (1946) Report on anti-fouling research, 19421944. Journal of the Iron \&Steel Institute $2: 297-333$

HAVINGA, B.H. (1956) Mussel culture in the Dutch Waddensea. Rapports et Proces-Verbaux, I.C.E.S. $140(3): 49-52$

HAVINGA, B.H. (1964) Mussel Culture. Sea Frontiers. $10(3): 155-166$

HEATH, E. \& MORELAND, J.M. (1967) Marine Fishes of New Zealand. A.H.\& A.W. Reed, Wellington, 56pp HEINONEN, A. (1961) Reproduction of M. edulis in the Finnish southwestern archipelago in summer 1960. Archivium Societatis Botanicae Fennicae 'Vanamo' $16(2): 137-143$ 
HEWATT, W.G. (1935) Ecological succession in the Mytilus californianus habitat as observed in Monterey Bay, California. Ecology 16(2):244-251 HICKMAN, R.W. (1975) New source of seed mussels?

$$
\text { Catch } 75 \quad 2(7): 10-12
$$

HOUGHTON, D.R. (1971) Barnacles and fouling. In Marine Borers, Fungi and Fouling Organisms of Wood :197-214, edit. by Jones, E.B.G. \& Eltringham, S.K., Paris, O.E.C.D.

HOUGHTON, D.R. \& STUBBINGS, H.G. (1963) On the vertical distribution of Elminius modestus, Darwin. Journal of Animal Ecology 32:193-201 HRS-BRENKO, M. (1972) The settlement of mussel larvae (Mytilus galloprovincialis Lmk.) in the Limski Canal in the Northern Adriatic Sea. XXIII Congres Assemblee plenaire d'Athenes, Comite des Etangs Sales et Lagunes, 1972

HRS-BRENKO, M. (1973) The study of mussel larvae and their settlement in Vela Draga Bay (Pula, the Northern Adriatic Sea). Aquaculture 2(2):173-182 HRS-BRENKO, M. (1974) The seasonal fluctuation of the mussel larvae in the Northern Adriatic Sea. Aquaculture 3:45-50

HRS-BRENKO, M. \& CALABRESE, A. (1969) The combined effects of salinity and temperature on larvae of the mussel Mytilus edulis. Marine Biology 4:224-226 
HRS-BRENKO, M. \& IGIC, L. (1968) Effects of freshwater and saturated seawater brine on the survival of mussels, oysters and some epibionts on them. Studies and Reviews, General Fisheries Council for the Mediterranean, F.A.O., Rome :29-44

IVANOV, A.I. (1971) The first successful experiment in the cultivation of mussels in the U.S.S.R. Rybnoe Khozyaitsvo $9: 18-19$

IWATA, K.S. (1951) Spawning of Mytilus edulis IX Mechanisms of spawning by temperature rise. Bulletin of the Japanese Society for Scientific Fisheries 17:94-95

JENKINS, J. (1974) Series of bulletins on mussel spatfall forecasts. Fishing Industry Board, mimeographed.

JONES, J.B. (1975a) Studies an animals closely associated with some New Zealand marine shellfish. Unpublished Ph.D. Thesis, Victoria University of Wellington.

JONES, J.B. (1975b) Nematopsis n sp (Sporozoa : Gregarina) in Perna canaliculus. New Zealand Journal of Marine and Freshwater Research 9(4):567-568

JONES, E.B.G. \& EITRINGHAM, S.K. (1971) edit Marine Borers, Fungi and Fouling Organisms of Wood, Paris, O.E.C.D., $367 \mathrm{pp}$

KENNEDY, V.S. (1976) Desiccation, higher temperatures and upper tidal limits of three species of sea mussels (Mollusca: Bivalvia) in New Zealand. Marine Biology $35(2): 127-137$ 
KINNE, O. (1963) The effects of temperature and salinity on marine and brackish water animals, I

Temperature. Ocaenography and Marine Biology Annual Reviews 1:301-340

KINNE, O. (1964) The effects of temperature and salinity on marine and brackish water animals, II Salinity and salinity/temperature combinations. Oceanography and Marine Biology Annual Reviews $2: 281-339$

KISEIEVA, G.A. (1966) Factors stimulating larvae metamorphosis of a lamellibranch Brachydontes lineatus (Gmelin) . Zoology 45(10):1571-1573

KITCHING, J.A. et al (1959) The ecology of Lough Ine VIII Mussels and their predators. Journal of Animal Ecology 28:331-341

KORRINGA, P. (1947) Relations between the moon and periodicity in the breeding of marine animals. Ecological Monographs $17(3): 349-381$

KORRINGA, P. (1951) Le Mytilicola intestinalis steuer (Copepoda parasitica) menace l'industrie mouliere en Zelande. Revue des Travaux, Office Science et Technologie de Peche Maritimes, Paris $17(2): 9-12$

KORRINGA, P. (1976) Farming Marine Oragnisms Low in the Food Chain. Elsevier Scientific Publishing Co., Amsterdam, $264 \mathrm{pp}$

KUNKLE, D.E. (1957) The vertical distribution of oyster larvae in Delaware Bay. Proceedings of the National Shellfisheries Association 48:90-9l 
LAMBERT, L. (1949) L'ostreiculture et la mytiliculture en Zelande (Pays Bas). Revue des Travaux 16(3) : $111-127$

LANDERS, W.S. \& RHODES, E.W. (1970) Some factors influencing predation by the flatworm Stylochus ellipticus (Girard), on oysters. Chesapeake Science $11(1): 55-60$

IE GALL, P. (1970) Etude des moulieres Normandes renouvellement, croissance. Vie et Milieu serie B Oceanographie $21(3): 545-90$

LOOSANOFF, V.L. (1945) Precocious gonad development in oysters induced in midwinter by high temperature. Science $102(2640): 124-125$

LOOSANOFF, V.L. (1946) Methods for cultivation of the edible mussel. Atlantic Fisherman $23(6): 6,20$ LOOSANOFF, V.L. \& DAVIS, H.C. (1950) Conditioning V. mercenaria for spawning in winter and breeding its larvae in the laboratory. Biological Bulletin, Woods Hole 98:60-65

LOOSANOFF, V.L. \& DAVIS, H.C. (1951) Delaying of spawning of lamellibranchs by low temperature. Journal of Marine Research 10(2):197-202

LOOSANOFF, V.L. \& DAVIS, H.C. (1963) Rearing of Bivalve molluscs. Advances in Marine Biology 1:1-136 LOSADA, E.L. et al (1971) Consideraciones biologicas de Choromytilus chorus en dos sustratos differentes. Biologia Pesquera, Chile 5:61-108 
LOUGH, R.G. (1974) A re-evaluation of the combined effects of temperature and salinity on survival and growth of Mytilus edulis larvae using response surface techniques. Proceedings of the National Shellfisheries Association 64:73-76

LUBET, P. (1957) Cycle sexuel de Mytilus edulis L. et de Mytilus galloprovincialis Lmk. dans le bassin d'Archacon (Gironde). Annee Biologique $33(1-2): 19-29$

LUBET, P. (1969) Biologie et exploitation des moules. La Peche Maritime $\quad: 947-952$ LUCKENS, P.A. (1970) Breeding, settlement and survival of barnacles at artificially modified shore levels at Leigh, New Zealand. New Zealand Journal of Marine and Freshwater Research 4(4):497-514 LUCKENS, P.A. (1975a) Competition and intertidal zonation of barnacles at Leigh, New Zealand. New Zealand Journal of Marine and Freshwater Research 9(3) $: 379-394$

LUCKENS, P.A. (1975b) Predation and intertidal zonation of barnacles at Leigh, New Zealand. New Zealand Journal of Marine and Freshwater Research 9(3) : 355-378

LUCKENS, P.A. (1976) Settlement and succession on rocky shores at Auckland, North Island, New Zealand. New Zealand Oceanographic Institute Memoir no.70 $64 \mathrm{pp}$ 
LUNETTA, J.E. (1969) Fisiologia da reproducao dos mexilhoes (Mytilus perna L. Mollusca Lamellibranchia). Zoologia e Biologia Marinha 26:33-111

LUTZ, R.A. (1974) Raft cultivation of mussels in Maine waters - its practicability, feasibility and possible advantages. Maine Sea Gwant Bulletin no.4, University of Maine at Orono, 27pp MACLEAN, J.L. (1972) Mussel culture : methods and prospects. Australian Fisheries Paper n.20,13pp MANDELLI, E.F. \& ACUNA, A.C. (1975) The culture of the mussel Perna perna, and the mangrove oyster Crassostrea rhizophorae in Venezuela. Marine Fisheries Review $37(1): 15-18$

MANN, H. (1956) The influence of Mytilicola intestinalis (Copepoda parasitica) on the development of the gonads of Mytilus edulis. Rapports et Proces Verbaux des Reunions, ICES $140(3): 57-58$

MANNING, J.H. \& WHALEY, H.H. (1954) Distribution of oyster larvae and spat in relation to some environmental factors in a tidal estuary. Proceedings of the National Shellfisheries Association 45:56-65

MARTINEZ, R.E. (1967) Identificacion y descripcion de la larva veliconcha $y$ dissoconcha del mejillon comestible, Perna perna (L) del oriente de Venezuela. Investigaciones Pesqueras serie Recursos y Explotacion Pesqueros, Ministerio de Agricultura y Cria $1(3): 96-113$ 
MARTINEZ, R.E. (1971) Estado actual de la biologia y cultivos de moluscos comestibles en Venezuela. F.A.O. Fisheries Reports 7(2): 173-181

MASON, J. (1958) A possible lunar periodicity in the breeding of the scallop Pecten maximus (L.). Annals and Magazine of Natural History 13 $: 601-602$

MASON, J. (1969) Mussel raft trials succeed in Scotland. World Fishing, April $1969: 22-24$

MASON, J. (1971) Mussel cultivation. Underwater Journal $3(2): 52-59$

MASON, J. (1972) The cultivation of the European mussel Mytilus edulis Linnaeus. Oceanography and Marine Biology, Annual Reviews 10:437-460 MATVEYEVA, T.A. (1953) Influence of desalting on reproduction of mussels of the East Murman. Papers of the Academy of Sciences of the U.S.S.R. $75(1)$

MCFARLANE, S. (1971) New Zealand commercial mussel farming experiments in the Hauraki Gulf. Report on Mussel Cultivation Seminar, October 1971, Fishing Industry Board :10-12 MELROSE, M.J. (1975) The marine fauna of New Zealand : Family Hymenostomidae (Crustacea, Decapoda, Brachyura). New Zealand Oceanographic Institute Memoir no. 34, $123 \mathrm{pp}$

MILLAR, R.H. (1971) Ascidians as fouling organisms. In : Jones, E.B.G. \& Eltringham, S.K. (edit), Marine Borers, Fungi and Fouling Organisms of Wood, O.E.C.D. , Paris, :185-195 
MIYAZAKI, I. (1938) On fouling organisms in the oyster farm. Bulletin of the Japanese Society for Scientific Fisheries 6(5):223-232

MIYAZAKI, I. (1962) On the identification of lamellibranch larvae. Bulletin of the Japanese Society of Scientific Fisheries 28:955-966

MOELLER, H.W. \& GIORDANO, S. (1975) A method for cultivating molluscs. Aquaculture 5:215-218 MORTON, J. \& MILIER, M. (1973) The New Zealand Seashore Collins, London, Auckland, $653 \mathrm{pp}$ MUUS, K. (1973) Settling, growth and mortality of young bivalves in the $\varnothing$ resund. Ophelia 12:76-116 NEEDLER, A.W.H. (1940) Helping oyster growers to collect spat by predicting sets. Fisheries Research Board of Canada, Progress Report no. 27

NELSON, T.C. (1928) Pelagic dissoconchs of the common mussel Mytilus edulis, with observations on the behaviour of the larvae of allied genera. Biological Bulletin, Woods Hole 55:180 NELSON, T.C. (1954) Observationa on the behaviour and distribution of oyster larvae. Proceedings of the National Shellfisheries Association 45 : $23-28$

NEWCOMBE, C.L. (1935) A study of the community relationships of the sea mussel Mytilus edulis L. Ecology $16(2): 234-243$

NIKOLIC, M. \& STOJNIC, I. (1963) A system of mussel culture. Proceedings of the General Fisheries Council for the Mediterranean, F.A.O. 7:251-255 
NUNES, L.P. (1951) Mortalidade dos mexilhoes. Boletin de Pesca, Lisboa 31:115-122

ORNITHOLOGICAL SOCIETY OF NEW ZEALAND INC. (1970)

Annotated checklist of the Birds of New

Zealand, A.H.\&A.W. Reed, Wellington, $96 \mathrm{pp}$

PAINE, R.T. (1971) A short-term experimental investigation

of resource partitioning in a New Zealand rocky intertidal habitat. Ecology $52(6)$ : $1096-1160$

PERKINS, E.J. (1974) The Biology of Estuaries and

Coastal Waters. Academic Press, London, 678pp

PIKE, R.B. (1971a) Mussel biology. Report on Mussel

Cultivation Seminar, October 1971, Fishing Industry Board :27

PIKE, R.B. (1971b) Report on mussel farming and mussel biology for the Fishing Industry Board. F.I.B. Report no.71/1, mimeographed, 10pp

POWELL, A.W.B. (1961) Shells of New Zealand. Whitcombe \& Tombs, Christchurch, $203 p p$

PROVENZANO, A.J. (1961) Effects of the flatworm Stylochus ellipticus on oyster spat in Massachusetts. Proceedings of the National Shellfisheries Association $50: 83-88$

RALPH, P.M. \& HURLEY, D.E. (1952) The settling and growth of wharf-pile fauna in Port Nicholson, Wellington, New Zealand. Zoology Publications of Victoria University of Wellington no.19 
RAPSON, A.M. (1952) The toheroa, Amphidesma ventricosum Gray (Eulamellibranchiata), development and growth. Australian Journal of Marine and Freshwater Research 3(2):170-198

REES, C.B. (1950) The identification and classification of lamellibranch larvae. Hull Bulletins of Marine Ecology 3:73-104

ROJAS, J.C. (1969) Fluctuacion mensual de las larvas y crecimiento del mejillon perna perna (L.) y las condiciones ambientales de la ensanada de Guatapanare, Venezuela. Boletino del Instituto Oceanografico del Universita del Oriente $8(1 \& 2): 13-20$

RYTHER, J.H. (1968) The status and potential of aquaculture, particularly invertebrate and algal culture, Part II, U.S. Department of Commerce, National Bureau of Standards, mimeographed, 26 lpp

SAVAGE, R.E. (1956) The great spatfall of mussels in the River Conway estuary in spring 1940. Fisheries Investigations, London, Series II $20(7):$

SCHEER, B.T. (1945) The development of marine fouling communities. Biological Bulletin, Woods Hole $89(11): 103-121$

SEED, R. (1969a) The ecology of Mytilus edulis (L.) Lamellibranchiata, on exposed rocky shores, I Breeding and Settlement. Decologia (Berlin) $3: 277-316$ 
SEED, R. (1969b) The ecology of Mytilus edulis (L.)

Lamellibranchiata, on exposed rocky shores, II Growth and Mortality. Oecologia (Berlin) $3: 317-350$

SKERMAN, T.M. (1958) Marine fouling at the port of

Lyttelton. New Zealand Journal of Science $1(2): 224-257$

SKEPMAN, T.M. (1959) Marine fouling at the Port of Auckland. New Zealand Journal of Science $2(1): 57-94$

SKERMAN, T.M. (1960) Ship fouling in New Zealand waters: a survey of marine fouling organisms from vessels of the coastal and overseas trades. New Zealand Journal of Science 3(4) $: 620-648$

THORSON, G. (1946) Reproduction and larval development of Danish marine bottom invertebrates, with special references to the planktonic larvae in the Sound (Oresund). Meddelelser Kommissionen Dansk Havundersogelser series Plankton 4:1-523

THORSON, G. (1950) Reproductive and larval ecology of marine bottom invertebrates. Biological Reviews $25: 1-45$

TORTELL, P. (1974) Mussel Research Programme : Investigation into Settlement Behaviour of Mussels and the Hydrology of a Selected Area with a View to Farming the Shellfish, Fourth Report June 1974, mimeographed, Victoria University of Wellington, $32 \mathrm{pp}$ 
TORTELL, P. (1975) Southeast Asian Fisheries Development

Center, Mussel Research Program, First Interim Report, mimeographed,

TORTELI, P. (1976) Southeast Asian Fisheries Development

Center, Mussel Research Program, Second Interim Report, mimeographed, $16 \mathrm{pp}$

TORTELL, P. \& YAP, W.G. (1976) The status of mussel

farming in the Philippines. Eish Farming

International (in press)

UROSA, J.L. (1972) Algunos depredadores del mejillon

comestible Perna perna (I.). Boletino del

Instituto d'oceanografia dell'Universita del

Oriente $11(1): 3-18$

VERWEY, J. (1952) On the ecology and distribution of cockle and mussel in the Dutch Waddensee, their role in sedimentation and the source of their food supply. Archives Neerlandaises Zoologie $10: 171-239$

VERWEY, J. (1954) De mossel en zijn eisen. Faraday 24 : 1-13

VISSCHER, J.P. (1928) Nature and extent of fouling of ships' bottoms. Bulletin of the U.S. Bureau of Fisheries 43:193-252

WALLIS, R.L. (1975) Thermal tolerance of Mytilus edulis of Eastern Australia. Marine Biology 30:183-191 WAUGH, G.D. (1954) The occurrence of Mytilicola intestinalis (Steuer) on the east coasts of England. Journal of Animal Ecology $23(2): 364-367$ 
WAUGH, G.D. (1966) A crop from the sea. Geographical Magazine, London 39(4):263-267

WAUGH, G.D. (1971) Prospects for mussel cultivation in New Zealand and observations on the Spanish mussel cultivation industry. Report on Mussel Cultivation Seminar, October 1971, Fishing Industry Board, :1-3

WEISER, W. (1952) Investigations on the microfauna inhabiting seaweeds on rocky coasts. Journal of the Marine Biological Association, U.K. 31 : $145-174$

WEISS, C.M. (1948) The seasonal occurrence of sedentary marine organisms in Biscayne Bay, Florida. Ecology $29(2): 153-172$

WHITE, K.M. (1937) Mytilus. Liverpool Marine Biology Committee Memoirs no. 117

WILSON, B.R. \& HODGKIN, E.P. (1967) A comparative account of the reproductive cycles of five species of marine mussels (Bivalvia : Mytilidae) in the vicinity of Freemantle, Westerm Australia. Australian Journal of Marine and Freshwater Research $18: 175-203$

WISELY, B. (1959) Factors influencing the settling of the principal marine fouling organisms in sydney Harbour. Australian Journal of Marine and Freshwater Research $10(1): 30-44$ 
WISELY, B. (1963) Detection and avoidance of a cuprous oxide antifouling paint by bivalve and gastropod larvae (Mollusca). Australian Journal of Marine and Freshwater Research 14(I):60-69

WISELY, B. (1964) Aspects of reproduction, settling and growth in the mussel Mytilus edulis planulatus Lamarck. Journal of the Malacological Society of Australia $8: 25-30$

WOOD, L. \& HARGIS, W.J. (1971) Transport of bivalve larvae in a tidal estuary. In : Fourth European Marine Biology Symposium, edit D.J. Crisp, :29-44

WOODS HOLE OCEANOGRAPHIC INSTITUTION (1952) Marine Fouling and its Prevention. United States Naval Institute, Maryland, 388pp

YAP, W.G. et al (1976) An enquiry into the biology and farming of the mussels Mytilus smaragdinus and Modiolus metcalfei in the Philippines, First Progress Report, Southeast Asian Fisheries Development Center, Philippines. mimeographed, $50 \mathrm{pp}$

YOUNG, R.T. (1945) Stimulation of sparning in the mussel (Mytilus californianus) E Ecology 26(1):58-69 
SECTION FOUR

PROSPECTS FOR MUSSEL FARMING IN THE BEATRIX BASIN 
Among the factors that need to be considered in assessing the suitability of an area for the suspension culture of mussels are the following: the degree of exposure to wind and wave action; the depth of water and circulation patterns; water temperature, salinity and productivity; enrichment and other forms of water pollution; road access; adjacent land usage; and conflicting interests (Brick 1970, Guard 1971, Bardach et al 1972, Anon 1975, Dare \& Davies 1975, Figueras 1976).

Beatrix Basin forms part of the Cook strait climatological regime and is subject to high winds for most of the year (Robertson, 1973) (see Figures 2.7 and.2.10). The high hills which surround the Basin on most aspects tend to funnel the wind, augmenting its force at sea level. Exposure to wind action can be severe. However, windgenerated waves over $1.25 \mathrm{~m}$ are uncommon outside the central and eastern regions (see Figure 2.3) due to lack of fetch.

Commercial rafts often rise $1-2 \mathrm{~m}$ above the water surface (Plate 4.1). They are subject to wind action which can cause them to drag or break their moorings, or to sustain. structural damage. The use of such rafts in the Beatrix Basin would be restricted to the sheltered areas in the southern region. The risk of damage by wind and waves in 
Commercial mussel rafts from the Marlborough Sounds. The raft in the upper right picture is a spat-collecting raft, hence the proximity of ropes to each other. Note the effect of tidal currents on the ropes suspended from the raft in the lower left picture. 

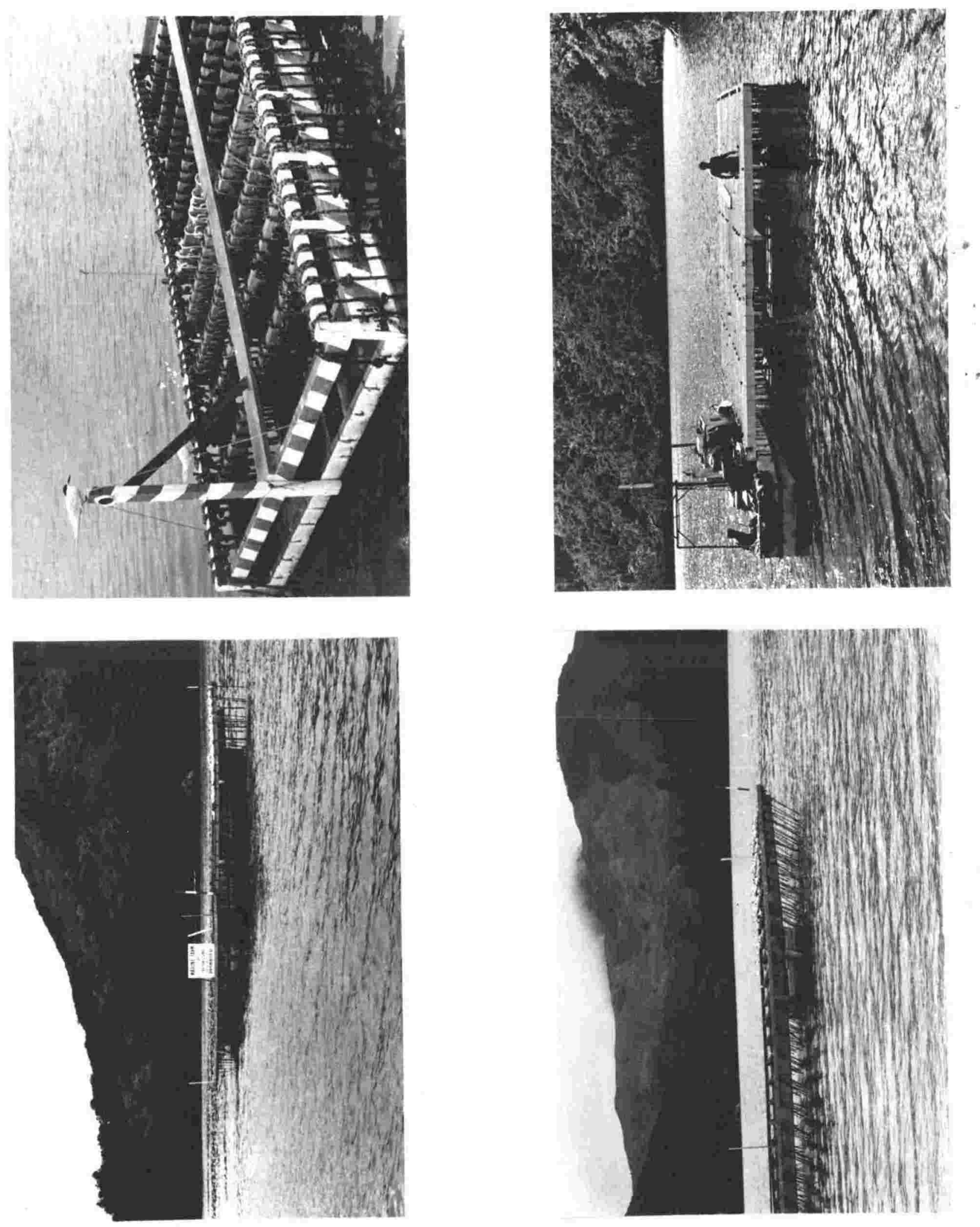
the more exposed areas is reduced when the long line system of buoys (Flate 4.2) is employed. The low profile and rounded surface of the buoys offer little resistance to the wind. Waves can break right over the buoys rather than strike against them and the flexibility of the long line eliminates the danger of structural damage from differential stress.

Mussel rafts in the Galician bays of Spain are largely confined to depths of about 10m (Bardach et al, 1972) to obtain protection from storms, maintain navigational channels and avoid anchoring complications. The $20 \mathrm{~m}$ isobath in most of the Beatrix Basin is comparatively close inshore (see Figure 2.5). Mussel farming structures moored in up to $20 \mathrm{~m}$ depths (even at $25 \mathrm{~m}$ in the southern region) will not be unduly exposed to wind and wave action, neither will they hinder navigation. However, anchorage in these deeper waters could present problems and will certainly add to the cost of installation.

Water circulation in the Beatrix Basin is discussed in Section Two and tidal current patterns illustrated in Figure 2.21. Surface water movement is strongly influenced by the wind and areas having favourable, fast currents are inevitably exposed to the wind. Such areas as found in the eastern region, could be used for spat collecting since only small structures are required for this purpose and it is known that fast water currents 
Close-up of polyethylene buoys used in the long line assembly described in the text. 


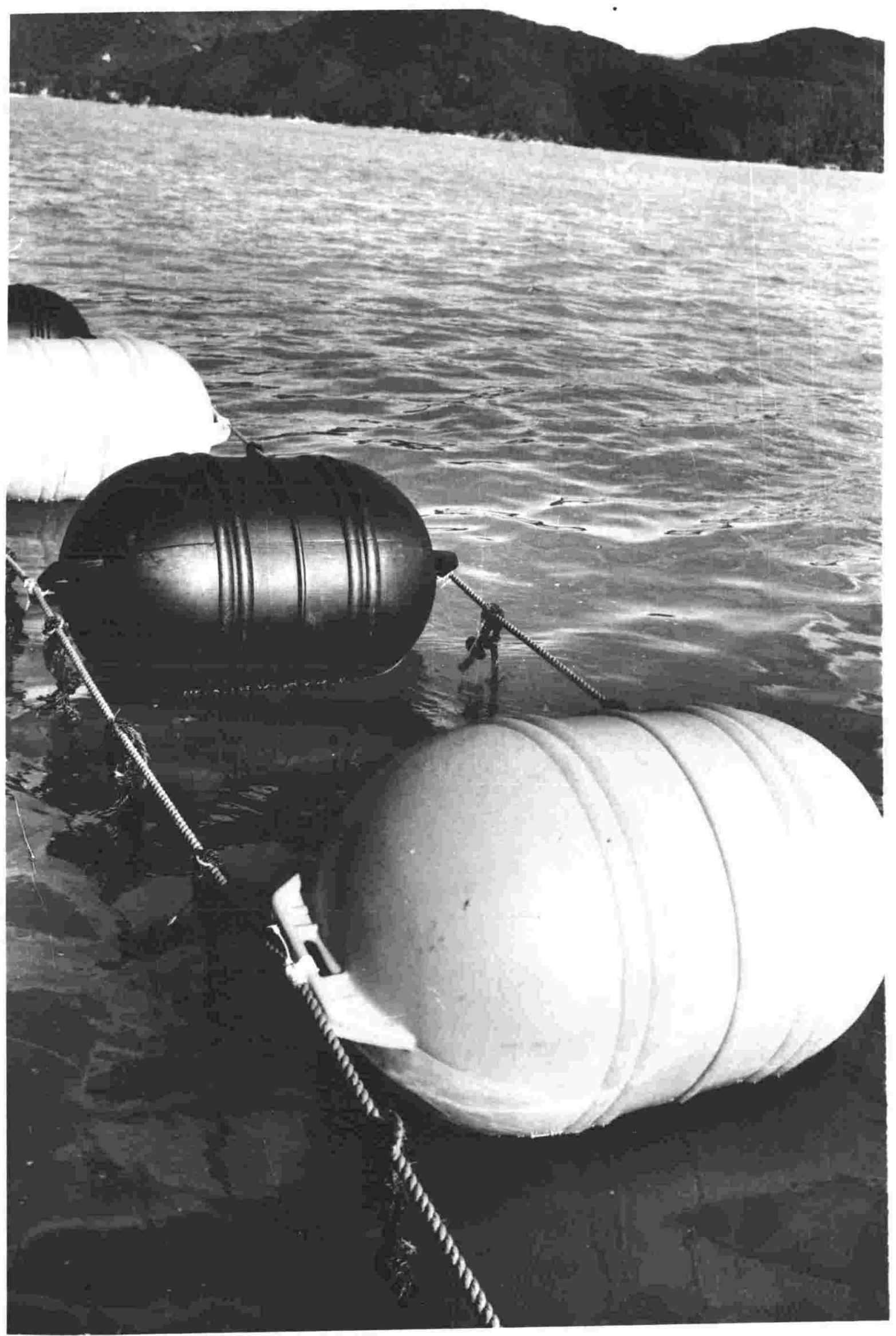


enhance settlement (Woods Hole Oceanographic Institution 1952, Wisely 1954).

Differences in temperature and salinity between various areas within the Beatrix Basin are only slight (Figures 2.13 and 2.14) under normal conditions. Occasional lowering of salinity can take place in the southern region as a result of its weaker circulation, extensive catchment area and higher rainfall (see Section Two). However, the influx of freshwater is soon dissipated and while it does not seem to effect the mussel population there appears to be some mortality among tunicates (see also Hrs-Brenko \& Igic 1968, Bardach et al 1972). It appears that in Elie Bay, in years of low rainfall in summer, fouling organisms are more prevalent.

Methods for assessing the food available for mussels are discussed fully in Appendix A. The concentration of particulate organic nitrogen in Beatrix Basin compares favourably with records from Spanish mussel growing areas (see Benitez-Alvarez, 1965) and it appears unlikely that food will be a limiting factor in the event of intensive mussel farming.

Mussels are susceptible to pollution from industrial wastes (Fossato \& Siviero 1974, Kerkhoff 1974) as well as domestic wastes (Venkataraman \& Sreenivasan 1955, Duff 1967, Mason 1971). Perna canaliculus has a tendency to 
accumulate lead and iron (Nielsen \& Nathan, 1975). Beatrix Basin is entirely free of any domestic or industrial discharges but pesticide and fertilizer residues as well as animal wastes could enter the water due to the steep topography of the area which results in considerable surface runoff after rain. However, the small concentrations involved, the large dilution factor and favourable water currents are expected to preclude any serious pollution from most of the Basin.

There are three native bush reserves and one recreational area administered by the Marlborough Maritime Park Board in the Beatrix Basin (Department of Lands \& Survey 1969, Trotter 1974). The reserves are situated on the western shore of Beatrix Bay, the headland behind Waimaru and Te Puraka Points and the eastern side of Wet Inlet. Hopai Bay is designated a recreational area and is the venue of the annual Hopai sports on New Year's Day. The remainder of the land surrounding the Basin is farmland, mainly sheep but with some beef cattle. There are no more than ten permanent households in the area. Guest house accommodation. is found at wet Inlet and Elie Bay and private holiday homes are situated on the western shores of Crail Bay and in Laverique Bay. A sawmill at Manaroa (Clova Bay) was closed down in 1973. Visitors to the area are few and restricted to the two guest houses except on the annual sports day at Hopai. Road access is by a tortuous loose gravel road from Picton or Havelock 
and most visitors arrive by the mail boat which visits the area twice weekly. Few fishing parties use Beatrix Basin and the area is not popular for boating. Commercial fishermen have been seen dredging on rare occasions near the entrance to Beatrix Bay.

The remote situation of the Beatrix Basin gives the prospective marine farmer a degree of insulation from holiday makers, boat owners and other people with conflicting interests; it also means less likelihood of pollution. However, remoteness will create some problems for the mussel farmer especially at harvest time. The road head at the Manaroa wharf is the only alternative route to the long sea route to Havelock where the nearest processing facilities are situated.

Mussel farming operations are excluded from Hopai Bay due to recreational use. After taking into account navigational requirements, marine farming in the rest of the Beatrix Basin is restricted solely by the degree of exposure and depth of water. A corridor, about $200 \mathrm{~m}$ wide, between the $5 \mathrm{~m}$ and $20 \mathrm{~m}$ isobaths follows the coastline on the western shores of Crail Bay and the eastern shores of Beatrix Bay. These, together with some larger. embayments, are thought to be suitable for mussel farming. Figure 4.1 shows the areas which could be utilised for mussel farming without any extraordinary precautions, those areas which could be used if adequate mooring arrangements 
Potential mussel farming areas in the Beatrix Basin. 


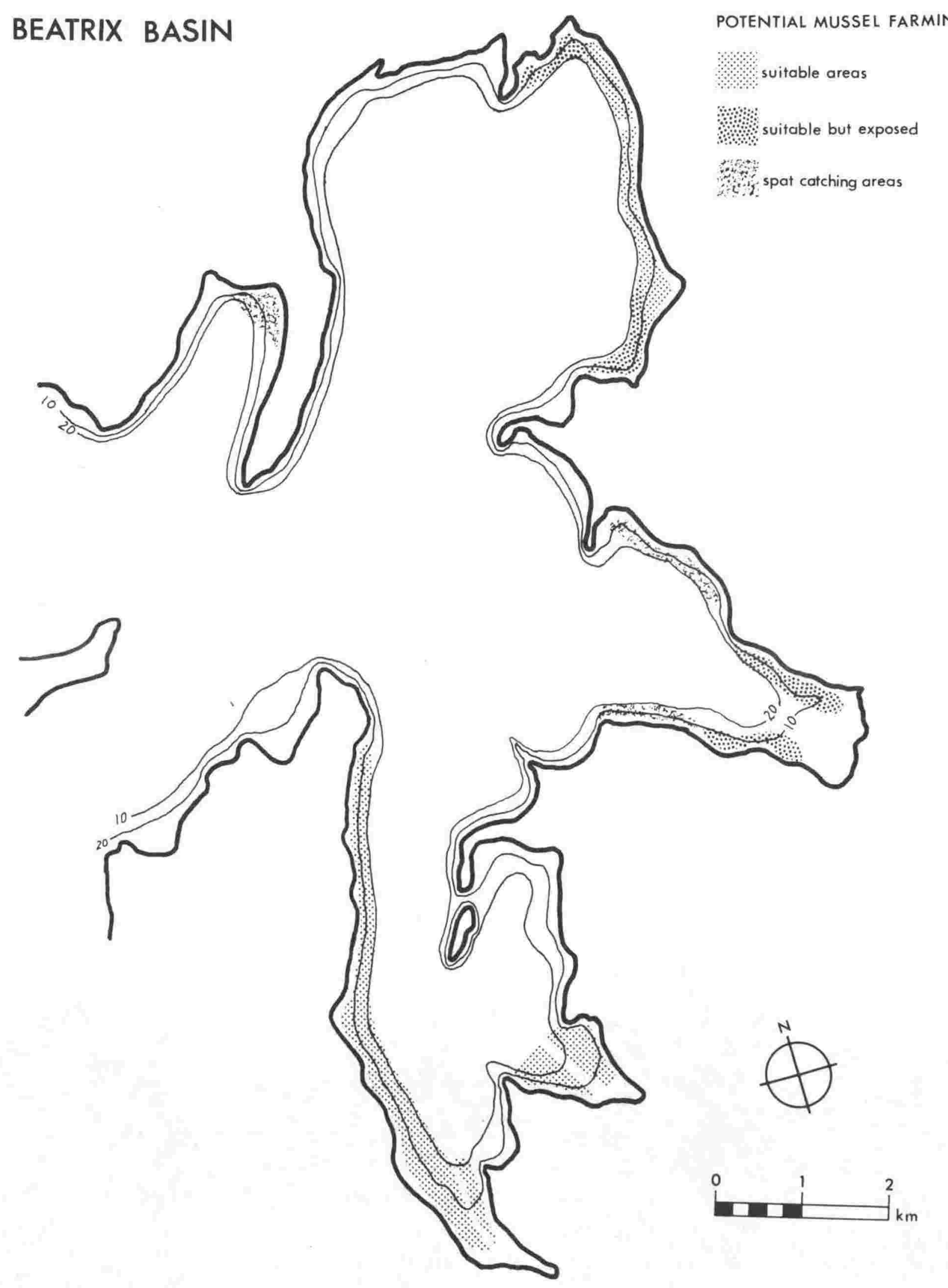


are provided, and those areas which while too exposed for normal farming operations are thought to be suitable for spat collecting. An estimated 328 hectares appear suitable for mussel farming in the Beatrix Basin, of these, 76 hectares would require special precautions because of exposure.

A long line, 100m long, could be oriented at right angles to the coast within the corridor described above, allowing $50 \mathrm{~m}$ each end for mooring. If such long lines were spaced $10 \mathrm{~m}$ apart, each hectare would accommodate five lines. Each long line can carry 400 growing ropes (spaced $50 \mathrm{~cm}$ apart) and if the mean length of each rope (depending on depth of water and handling facilities at harvest time) were to be $5 \mathrm{~m}$, the total mussel rope on each long line would amount to $2000 \mathrm{~m}$. This makes a total of 10000 metres of rope per hectare.

Production estimates vary considerably. Bardach et al (1972) estimated that mussel production in Spain was about 600 tonnes/hectare/year when using rafts. However, Andreu (1973) showed that the figure is unrealistic since it is based on production from the raft area itself and fails to allow sufficiently for the considerable area which a raft requires to swing with the tidal currents and wind action. Mandelli \& Acuna (1975) appear to have made the same mistake when they estimated that a yield of 1000-1500tonnes/hectare/year was possible by raft 
culture in Venezuela. While raft cultivation of mussels must make plenty of space available for the movement of the rafts themselves, the long line system does not require such extensive spaces between the structures. An estimated 20 tonnes/hectare/year using long lines in Kenepuru Sound (Anon, 1975) appears to be a highly conservative figure and no indication is given as to how the estimate was derived.

A mean settlement of about 25 mussels per $10 \mathrm{~cm}$ collector was obtained during the present study (see Table 3.7), indicating that a density of about 250 mussels per metre could realistically be expected. Mean mussel weight at harvest is about $40 \mathrm{~g}$ hence the yield per metre of rope would be about lokg. If a hectare carries 10000 metres of rope, at a rate of $10 \mathrm{~kg} / \mathrm{m}$, total production would be 100 tonnes per hectare per year. If all of the potential 328 hectares in the Beatrix Basin are employed for mussel farming, up to 32800 tonnes of mussels per year could be expected. At a return of $\$ 300$ per tonne (Anon, 1975) the harvest of mussels from the Beatrix Basin could be worth nearly \$10 million. 
I would like to express my gratitude to Professor J.T. Salmon and Dr R.B. Pike of the zoology Department, Victoria University of Wellington, for their supervision of the programme, the facilities they made available and their constant encouragement and assistance. Dr Pike also spent many long hours reading and discussing the manuscript as also did Dr R.G. Wear and Professor J.B. Wells.

A large number of people and commercial firms have helped me in many ways and their assistance is gratefully acknowledged in the appropriate sections of this thesis. However, I would like to mention in particular Mr W.B. MacQueen and Mr R.Nicol of the R.V. Tirohia for bearing with me in all sorts of weather; the Halliday and parsonson families of Elie Bay for Sounds-style hospitality and assistance; Mr G. Grainger of the Island Bay Marine Laboratory for meticulously handcrafting a number of pieces of equipment; Mrs J. Benfield and Mr M. Arapoff for patience and expertise needed to satisfy my photographic demands; Miss N. Knuckey for painstakingly typing part of the manuscript; and Mr G. McLean for printing the diagrams.

Mr. J. Jenkins of the Fishing Industry Board shared with me a great deal of first hand information on the mussel 
farming situation in the Marlborough Sounds.

My wife Dorothy has stood courageously by my side while I returned to the university as a student. Without her help and understanding I would not have been able to undertake this study.

In conducting this research programme I have made use of funds made available by the Fishing Industry Board, the University Grants Committee, the Nuffield Research Foundation, and the Internal Research Grants Committee of Victoria University. 
ANDREU, B. (1973) Perspectivas de la acuicultura marina en España. Informes Tecnicos del Instituto de Investigaciones Pesqueras no.9, 47pp

ANON (1975) Long line mussel farming shows promise.

Catch $75 \quad 2(4): 6-7$

BARDACH, J.E. etal (1972) Aquaculture - The Farming and Husbandry of Freshwater and Marine Organisms Wiley Interscience, New York, 868pp BENITEZ-ALVAREZ, J. (1965) Algunas observaciones del nitrogeno organico en el agua del mar y la composicion quimica del mejillon (M. edulis) en la ria de Vigo. Boletino del Instituto Oceanografico, Universita del Oriente 4(1):172-183 BRICK, R.W. (1970) Some aspects of raft culture of oysters in Hawaii. Hawaii Institute of Marine Biology, Technical Report no.24, mimeographed, $47 \mathrm{pp}$

DARE, P.J. \& DAVIES, G. (1975) Experimental suspended culture of mussels (Mytilus edulis L.) in Wales using spat transplanted from a distant ground. Aquaculture $\quad 6: 257-274$

DEPARTMENT OF LANDS \& SURVEY (1969) Marlborough Sounds Reserves. The Reserves Board, Blenheim, 3lpp 
DUFF, M.F. (1967) The uptake of enteroviruses by the New Zealand marine blue mussel Mytilus edulis aoteanus. American Journal of Epidemiology $85(3): 486-493$

FIGUERAS, A. (1976) Desarrollo actual del cultivo del mejillon (Mytilus edulis L.) y posibilidades de expansion. F.A.O. Technical conference on Aquaculture, Kyoto, Japan, 1976 , Document FIR: AQ/Conf $/ 76 / r .7$

FOSSATO, V.U. \& SIVIERO,E. (1974) Oil pollution monitoring in the lagoon of Venice using the mussel Mytilus galloprovincialis. Marine Biology 25(1):1-16

GUARD, C. (1971) Mussel farming project in the Marlborough Sounds. Report on Mussel Cultivation Seminar, October 1971, Fishing Industry Board :21-23 HRS-BRENKO, M. \& IGIC, L. (1968) Effects of freshwater and saturated seawater brine on the survival of mussels, oysters and some epibionts on them. Studies and Reviews, General Fisheries Council for the Mediterranean, F.A.O., Rome :29-44 KERKHOFF, M. (1974) Oilpollution of shellfish areas in the Oosterschelde Estuary, December 1973. I.C.E.S. Fisheries Improvement Committee, Document ICES C.M. 1974/E:13, mimeographed, 7pp MANDELLI, E.F. \& ACUNA, A.C. (1975) The culture of the mussel perna perna and the mangrove oyster Crassostrea rhizophorae in Venezuela. Marine Fisheries Review $37(1): 15-18$ 
APPENDIX A

DIFFICULTIES IN THE DETERMINATION OF THE AVAILABLE FOOD FOR MUSSELS 
Not all suspended particles filtered by mussels are retained and used as food (MacGinitie 1945, Korringa 1949, Thiesen 1972). This is not because of size since they can retain particles down to the size of large colloids (Verwey, 1952), and mussels have been reared on an exclusive bacterial diet (Zobell \& Feltham 1938, Zobell \& Laridon 1937). Jorgensen (1949) observed young mussels feeding on suspensions of different types and came to the conclusion that if the animals are disturbed or they dislike the food, they can alter the retention rate of their filtering mechanism - thus they can allow graphite particles through while retaining smaller flagellates. That mussels can be selective in their feeding is beyond doubt.

The filtering mechanism of mussels was described by Verwey (1952) who postulated that while the laterofrontal cilia of the gills functioned as food retainers, their efficiency was limited and therefore some other filtering device must be present. Jorgensen $(1960,1966)$ describes how, when feeding undisturbed in waters of rather low concentrations of suspended matter (as is normal in natural seawater), mussels tend to cover the entire gill surface with a mucus sheet which increases filtering efficiency. When disturbed or when feeding in waters with a high amount of suspended material, or when the food is unusual (as is often the case in an experimental situation), the mucus sheet is not used 
and the sorting mechanism starts to function. It seems therefore that mussels in their natural surroundings are capable of filtering extremely small particles from the water and that they are not unduly selective unless the concentration of suspenced material is high. Any suspended material can therefore be filtered unless it is too large (over $40 \mu \mathrm{m}$ ) to enter the ostia. This means that besides the living phytoplanktonic organisms, mussels also feed on detrital and faecal matter, which in enclosed bays and estuaries could make up a high percentage of the total suspended matter $(86 \%$ in the Ria de Vigo, according to Fraga, 1967). In fact the mean proportion of phytoplankton retained is only $9 \%$ while it is $30 \%$ in the case of detritus (Fraga \& Vives, 1960).

The most widely used method of assessing productivity is by determining the concentration of photosynthetic pigments by spectrophotometry. But chlorophyll is not necessarily a good index of organic matter (Steele \& Baird 1961) since it is quickly lost from organic detrital matter and such measurements would therefore give an underestimation of the total food available for mussels. Phosphorus, like chlorophyll, is also quickly decomposed, mineralised or denatured following the death of the organism (Menzel \& Ryther, 1964) and is likewise therefore not a good indicator. 
Measurement of food production in situ or under simulated conditions by the uptake of labelled Carbon Dioxide (Steeman Nielsen 1951, 1952), or the production of Oxygen (Radakrishna, 1969), is also not entirely satisfactory since it only measures primary productivity and not total. food available for mussels.

Direct quantitative estimation by either weighing or counting techniques have been used by Utermohl 1931, Cole \& Knight Jones 1949, Krey 1949, Jensen \& Sakshaug 1970, Marshall et al 1972, and many others. These techniques are not only time consuming, but according to strickland \& Parsons (1959), give no measure of the food potential of the particles.

Two fractions of organic detrital matter that remain as a residue even below the euphotic zone are particulate carbon and particulate nitrogen (Menzel \& Ryther, 1964). According to Fraga (1959) the best indicator of the available food for mussels is particulate nitrogen.

5.3 COLLECTING THE SAMPLE

The method of sampling, the volume of water to be sampled, as well as the immediate treatment of the sample depend wholly on the subsequent method of chemical analysis. The concentration of particulate organic nitrogen is rather low and this necessitates the filtering of large volumes 
of water.

The particulate matter in the sample can be extracted by a continuous centrifuge (Richards \& Thompson, 1952) or by filtration. Filtration methods are superior (Creitz \& Richards 1955, Humphrey \& Wootton 1966) as they result in a higher retention rate. Humphrey \& Wootton (op. cit.) tested a variety of filters and found that Millipore membrane filters were considerably superior to either Whatman's glass fibre filters or the Schleicher and Schull paper filters, or in fact any others they tested with the exception of Soviet filters of the same type as Millipore. It seems that the various pore sizes have no effect on retention ability but make a considerable difference to the flow rate (Humphrey \& Wootton op. cit.).

Pumping the water sample through the filter enables the selection of large volumes of water from particular strata with minimal disturbance to the stratification, (Vollenweider, 1969). A peristaltic type pump is ideal since it also avoids contamination from the collector (Golterman, 1969). The water pressure generated by the pump must be controllable since an excess can damage both the filter and the organisms (Parsons, 1966). Humphrey \& Wootton (op. cit.) report no adverse effect on the organisms due to high suction pressure. The SCOR-UNESCO Working Group 17 (1966), however, recommend a maximum suction of two-thirds atmosphere as sufficient, since there is no material 
increase in flow rate with higher pressure.

The sample should ideally be analysed right away in order to avoid contamination, denaturing, or other changes. As this is not possible, a means of storage for transport must be found. Raymont (in Golterman ed. 1969) recommends freezing at $-20^{\circ} \mathrm{C}$ as a good general method. Sulphuric acid is normally used if the sample is to be analysed for nitrogen (Golterman, 1969).

5.4 CHEMICAL ANALYSIS

As a first step in the determination of nitrogen the sample has to be oxidised. Oxidation with permanganate, which had been used for a long time, has been ruled out by Lopez-Benito (1955), Fraga (1959) and Maciolek (1962). The latter author replaces the permanganate with dichromate. Hewitt (1958) boiled Chlorella in sodium hydroxide before determining nitrogen. A more recent development is the use of ultra-violet radiation to photo-oxidise the sample (Armstrong et al 1966, Armstrong \& Tibbetts 1968, Henriksen 1970). Digestion by sulphuric acid is the usual method and this is followed either by spectrophotometric determination - Nessler technique (Bendschneider \& Robinson 1952, Riley 1953, Jacobs 1962) or determination by titration - Kjeldahl technique (Krogh \& Keys 1934, Harvey 1951, among others). 
The only method generally recommended for the estimation of nitrogen by Golterman (1969) is the micro-kjeldahl technique. After digestion of the sample in a solution of sulphuric acid and sodium sulphate, the nitrogen (in the form of ammonia) is distilled out with a ParnasWagner apparatus and collected in boric acid. This ammonia is then estimated titrimetrically.

Samples were collected using the shipboard centrifugal pump on the $\mathrm{r} v$ Tirohia. The pump was set at 1000 revolutions per minute and the pressure adjusted to two-thirds atmosphere by the use of a bypass system. Water was filtered through a Millipore cellulose-acetate (Celotate) filter which was nitrogen-free and had a pore size of $0.8 \mu \mathrm{m}$ (see plate 5.1). The flowrate through the filter slowed down to almost nil usually after about an hour when about 50 litres had been filtered. The time it took to reach this stage varied and depended on the amount of suspended particulate matter.

The filter with sample was immediately introduced into a Kjeldahl flask containing $3 \mathrm{~g} \mathrm{Na}_{2} \mathrm{SO}_{4}$ in $8 \mathrm{ml} \mathrm{H} \mathrm{H}_{2} \mathrm{SO}_{4}$ and three selenium-impregnated boiling chips. The flask was then sealed and transported to the laboratory at ambient temperature. In the laboratory the sample was boiled for 
PLATE 5.1 WATER SAMPLING FOR PARTICULATE ORGANIC NITROGEN

Apparatus on $r \mathrm{v}$ Tirohia for collecting sample of particulate matter.
A - pressure gauge
B - by-pass
C - intake hose
D - filter holder

PLATE 5.2 ANALYSIS FOR DETERMINATION OF PARTICULATE ORGANIC NITROGEN

Apparatus for chemical analysis of filtrate.
A - microburners and exhaust tube
B - condenser for distilled ammonia
C - boric acid solution to collect ammonia distillate
D - modified Parnas-Wagner distiller
E - steam generator
F - micrometer burette for dispensing hydrochloric acid
G - sample holder with probe and mechanical stirrer
H - phi meter for determination of titration endpoint 
Plate $5 \cdot 1$

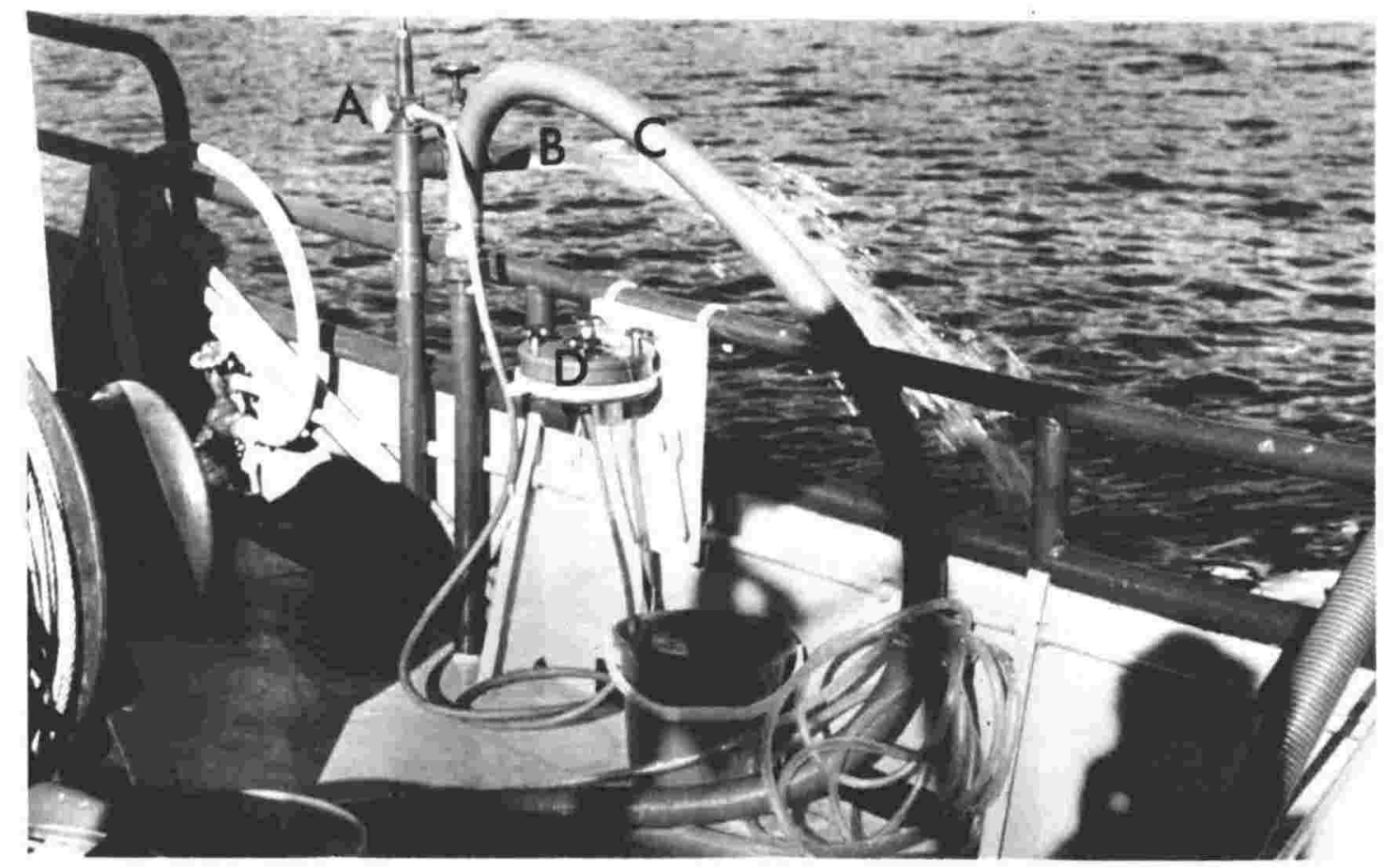

Plate $5 \cdot 2$

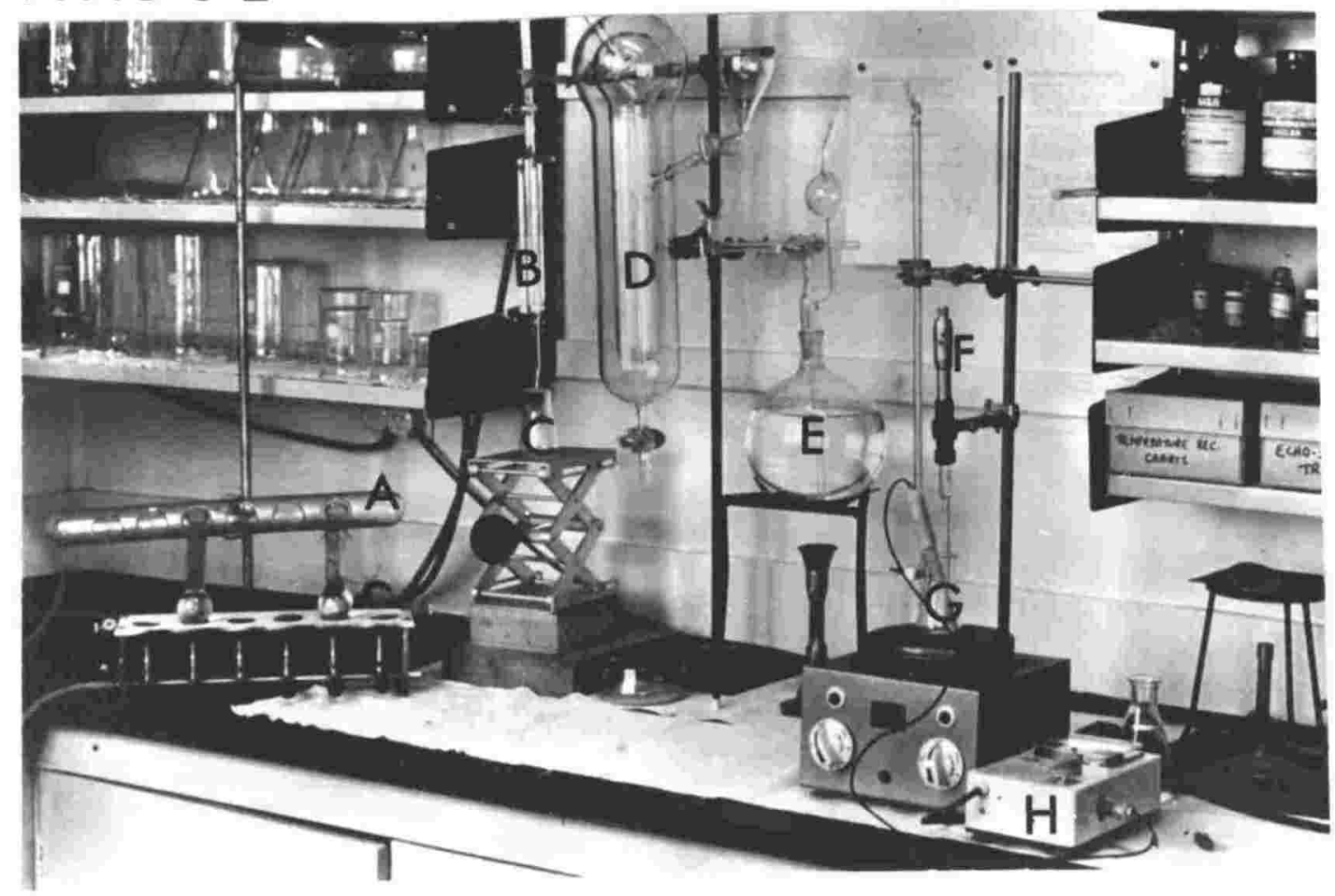


about 12 hours (Plate 5.2A) until the solution cleared to a pale straw colour. Distilled water was added on cooling to bring up the volume to $50 \mathrm{ml}$.

Aliquots $(15 \mathrm{ml})$ of the solution were then introduced into the inner chamber of the modified Parnas-Wagner distiller (Plate 5.2D) and steam was bubbled through after the addition of an excess of cold $50 \% \mathrm{NaOH}$. Ammonia was liberated and condensed (Plate 5.2B) and collected in an almost saturated solution of $\mathrm{H}_{3} \mathrm{BO}_{3}$ (Plate 5.2C). This was then titrated against standardized 0.1N HCl (Plate 5.2G). A micrometer burette (Plate $5.2 F$ ) was used to dispense the $\mathrm{HCl}$ and a pH meter (Plate $5.2 \mathrm{H}$ ) was used to determine the end-point after failure to do so using Bromocresol Green/ Methyl Red indicator. The following formula was then applied:-

$$
\frac{\mathrm{N}_{\mathrm{h}} \times \mathrm{V}_{\mathrm{h}}}{1000} \times \frac{\mathrm{mw} \mathrm{NH_{3 }} \times \mathrm{V}_{\mathrm{m}}}{\mathrm{V}_{\mathrm{a}} \times \mathrm{V}_{\mathrm{w}}} \times \frac{\mathrm{mwN}}{\mathrm{mwNH}}=\mathrm{N} \text { at } \mathrm{N} / \text { litre }
$$

where:

$$
\begin{aligned}
\mathrm{N}_{\mathrm{h}} & =\text { normality of } \mathrm{HCl} \\
\mathrm{V}_{\mathrm{h}} & =\text { volume of } \mathrm{HCl} \text { used in titration } \\
\mathrm{mw} \mathrm{NH}_{3} & =17 \\
\mathrm{~V}_{\mathrm{m}} & =\text { volume of digestion mixture }(50 \mathrm{ml}) \\
\mathrm{V}_{\mathrm{a}} & =\text { volume of aliquot (15ml) } \\
\mathrm{V}_{\mathrm{W}} & =\text { volume of water sample filtered } \\
\mathrm{mw} \mathrm{N} & =14
\end{aligned}
$$


In spite of the above measures it was not possible to determine the end-point of the titration accurately enough. A tentative mean figure of $11.78 \mu \mathrm{g}$ at $\mathrm{N} / \mathrm{litre}$ was obtained from water samples collected in early winter (June). This figure compares favourably with that obtained by BenitezAlvarez (1965) at the same time of the year in Ria de Vigo, Spain, namely $9.5 \mu \mathrm{g}$ at $\mathrm{N} / \mathrm{litre}$. The technique did not achieve the degree of discrimination necessary to determine seasonal variation. Two remedies were considered but neither was found feasible. Filtering a considerably greater volume of water would have provided sufficient particulate matter for precise determination of nitrogen, but this was not logistically possible. Further refinement of the technique was beyond the facilities available and my competence in the field of analytical chemistry. 


\section{ACKNOWLEDGMENTS}

I would like to thank Professor J.F. Duncan and Dr H. Keyzer of the Chemistry Department, Victoria University, for their help with the chemical analysis of samples. 
ARMSTRONG, F.A.J. et alia (1966) Photo-oxidation of organic matter in seawater by ultraviolet radiation, analytical and other applications. Nature 211: $481-3$

ARMSTRONG, F.A.J. \& TIBBETTS, S. (1968) Photochemical combustion of organic matter in seawater, for nitrogen, phosphorus and carbon determination. Journal Marine Biological Association U.K. $48(1): 143-152$

BENDSCHNEIDER, K. \& ROBINSON, R.J. (1952) A new spectrophotometric method for the determination of nitrite in seawater. Journal Marine Research $11: 87-96$

BENITEZ-ALVAREZ, J. (1965) Algunas observaciones del nitrogeno organico en el agua de mar y la composicion quimica del mejillon (M. edulis) en la ria de Vigo. Boletino Instituto Oceanografico Universita del Oriente $4(1): 172-183$

COLE, H.E. \& KNIGHT JONES, E.W. (1949) Quantitative estimation of marine nannoplankton. Nature 164: $694-696$

CREITZ, G.J. \& RICHARDS, F.A. (1955) The estimation and characterization of plankton populations by pigment analyses. $111 \mathrm{~A}$ note on the use of 'Millipore' filters in the estimation of plankton pigments. Journal Marine Research 14(3): 211-216 
FRAGA, F. (1959) Determinacion de nitrogeno organico suspendido y dissuelto en el agua del mar. Investigaciones Pesqueras XIV: 121-127

FRAGA, F. (1967) Hidrografia de la ria de Vigo, 1962, com especial riferencia a los compeustos de nitrogeno. Investigaciones Pesqueras 31(1): $145-160$

FRAGA, F. \& VIVES, F. (1960) Retencion de particulas organicas por el mejilion en los viveros flotantes. Reunion Productividad Del Mar Y Exploracion Pesqueras 4: $71-73$

GOLTERMAN, H.L. (1969) Methods for Chemical Analysis of Fresh Water. IBP Handbook No.8 Blackwell Scientific Publications. 188pp.

HARVEY, H.W. (1951) Micro-determination of nitrogen in organic matter without distillation. Analyst 76

HENRIKSEN, A. (1970) Determination of total nitrogen, phosphorus and iron in freshwater by photooxidation with ultraviolet radiation. Analyst $95: 601-608$

HEWITT, B.R. (1958) Spectrophotometric determination of protein in alkaline solution. Nature 182: 246 
HUMPHREY, G.F. \& WOOTON, M. (1966) Comparison in the techniques used in the determination of photosynthetic pigments. Determination of Photosynthetic Pigments in sea Water. U.N.E.S.C.O. $\mathrm{p} \cdot 37-63$

JACOBS, S. (1962) The quantitative determination of nitrogen by a further modification of the indanetrione hydrate method. Analyst 87: 3-6

JENSEN, A. \& SAKSHAUG, E. (1970) Producer-consumer relationship in the sea. 11 Correlation between Mytilus pigmentation and the density and composition of phytoplanktonic populations in inshore waters. Journal Experimental Marine Biology and Ecology 5: 180-186

JORGENSEN, C.B. (1949) The rate of feeding of Mytilus in different kinds of suspension. Journal Marine Biological Association U.K. 28: 333-344

JORGENSEN, C.B. (1960) Efficiency of particle retention and rate of water transport in undisturbed lamellibranchs. Journal du Conseil 24: 94-116 JORGENSEN, C.B. (1966) The Biology of Suspension Feeders. Pergamon. $357 \mathrm{pp}$.

KORRINGA, P. (1949) More light upon the problem of the oyster's nutrition? Bijdragen tot de Dierskunde $28: 237-248$ 
KREY, J. (1949) Uber Art und Menge des Seston in Meere.

Verhandlungen Deutschen Zoologischen Meere : 295*

KROGH, A. \& KEYS, A. (1934) Methods for the determination of dissolved organic carbon and nitrogen in seawater. Biological Bulletin, Woods Hole 67

LOPEZ-BENITO, M. (1955) Sobre determinacion de materia organica en el agua de mar con permanganate potasico. Investigaciones Pesqueras I: 67-72

MACGINITIE, G.E. (1945) The size and mesh openings in mucus feeding nets of marine animals. Biological Bulletin, Woods Hole 88: 107-111

MACIOLEK, J.A. (1962) Limnological organic analyses by quantitive dichromate oxidation. U.S. Department of Interior Fish \& Wildlife Service Report 60

MARSHALL, M. et alia (1972) A technique for collection of particulate organic matter in situ. Marine Biology 12: 194-195

MENZEL, D.W. \& RYTHER, J. (1962) The composition of particulate organic matter in the western north Atlantic. Limnology Oceanography 9: 179-186 PARSONS, T.R. (1966) The determination of photosynthetic pigments in sea water. A survey of methods. Determination of photo-synthetic pigments in sea water. U.N.E.S.C.O. pp.19-31

* Quoted in Journal Marine Research 1l(2): 2041952 
RADHAKRISHNA, K. (1969) Preliminary studies on marine production at Payakonda, Gulf of Kandalaska, White Sea. Marine Biology 3: 188-190

RICHARDS, F.A. with THOMPSON, T.F. (1952) The estimation and characterization of plankton populations by pigment analysis. 11 A spectrophotometric method for the estimation of plankton pigments. Journal Marine Research $11(2)$ : 156-172

RILEY, J.P. (1953) The spectrophotometric determination of ammonia in normal waters with particular reference to seawater. Analisi Chimica Acta $9: 575-589$

SCOR-UNESCO WORKING GROUP 17 (1966) Determination of Photo-synthetic Pigments in Sea Water. U.N.E.S.C.O. 69pp.

STEELE, J.H. \& BAIRD, I.E. (1961) Relations between primary production, chlorophyll and particulate carbon. Limnology Oceanography 6: 68-78

STEEMAN NIELSEN, E. (1951) Measurement of the production of organic matter in the sea by means of Carbon-14 Nature 167: 684-5

STEEMAN NIELSEN, E. (1952) The use of radioactive carbon $\left(C^{14}\right)$ for measuring organic production in the sea. Journal du Conseil 18: 117-140 
TAMMES, P.M. \& DRAL, A.D.G. (1955) Observations on the straining of suspensions by mussels. Archives Néerlandaises de Zoologie 11: 87-112

THIESEN, B.F. (1972) Shell cleaning and deposit feeding in M. edulis (Bivalvia). Ophelia 10: 49-55 UTERMOHL, H. (1931) Neue Wege in der quantitativen Erfassung des Planktons. Verhandlungen der Internationalen Vereinigung für theoretische und angewandte Limnologie Bd. 5: 576-597

VERWEY, J. (1952) On the ecology and distribution of cockle and mussel in the Dutch Waddensea. Their role in sedimentation and the source of their food supply. With a short review of the feeding behaviour of bivalve molluscs. Archives Néerlandaises de Zoologie $x: 171-239$

VOLLENWEIDER, R.A. edit. (1969) A Manual for Assessing Primary Production in Aquatic Environments. IBP Handbook No. 12 Blackwell Scientific Publications. $213 \mathrm{pp}$.

ZOBELL, C.E. \& IANDON, W.A. (1937) Bacterial nutrition of the California sea mussel. Proceedings Society for Experimental Biology and Medicine $36: 607-609$

ZOBELL, C.E. \& FELTHAM, C.B. (1938) Bacteria as food for certain marine invertebrates. Journal Marine Research $1: 312-327$ 
APPENDIX B

EXPERIMENTAL REARING OF MUSSEL LARVAE IN THE LABORATORY 
Bivalve larvae have been reared successfully by Guillard (1957), Hidu \& Ukeles (1969), Wisely (1964), Walne (1966), Loosanoff et al (1966), Lunetta (1969), Culliney (1971), Loosanoff (1971) and others, and the methods are well documented. Such larvae can be used to study the effects of numerous environmental factors upon their development and metamorphosis, as well as aid in positive identification of planktonic larvae.

Mussel larvae reared as part of the present project failed to metamorphose. Since this constituted only part of a wider programme it was not possible to go beyond these initial experiments. The methods and results are described below followed by a discussion as to the possible causes of failure.

6.2

METHODS

\section{The Physical Plant}

The larval rearing unit (Figure 6.1) consisted of a conditioning rack, constant temperature baths, a supply of filtered and sterilized seawater, an axenic culture bank and a culture of mixed algae.

The holding and conditioning rack for adult mussels 
DIAGRAM OF LARVAL REARING UNIT

The unit consists of three parts - a conditioning rack with heated and cold seawater, a supply of filtered and sterilized seawater, and constant temperature baths. 
consisted of twelve clear perspex tanks of c. 14 litres capacity, each supplied with cold and heated seawater, and drained by an overflow on the side. (vide plate 6.1) The tanks could be disconnected from the drain and removed for cleaning.

The cold water to the conditioning tanks came directly from the main reticulation of the laboratory $(90,000$ litre volume; 5,500 litres throughput per hour) and was kept at 100-110 litres/hour/tank. The heated water was supplied by a system similar to that described by Walne (1964). The wooden heating tank was lined with fibreglass and coated with a polyester resin. Heating was achieved by three $3 \mathrm{~kW}$ Vitreosil immersion heaters. A flow of up to 50 litres/ tank/hour could be maintained. Each tank received a supply of both cold and heated water and the final temperature in each tank was achieved by altering the proportions of cold and heated water. This made it possible to have a range of temperatures using the same source of heated water.

The constant temperature baths used for incubating the larvae were heated individually by $1.5 \mathrm{~kW}$ Inconel immersion heaters. Temperatures up to $35^{\circ} \mathrm{C}$ could be maintained with a variation of $\pm 2^{\circ} \mathrm{C}$. Each bath was covered by a clear perspex dome which conserved heat while avoiding water loss through evaporation.

Water for use in larval cultures was filtered and sterilized. 
PLATE 6.1

PLATE 6.2

PLATE 6.3

PLATE 6.4 
PLATE 6.1

LARVAL REARING UNIT

The conditioning rack showing the holding tanks, with the seawater heating tank in the upper centre of the picture.

PLATE 6.2

LARVAL REARING UNIT

The algal culture bank.

PLATE 6.3

LARVAI REARING UNIT

The filter holder and U.V. sterilizing unit are seen on the wall while the constant temperature baths are in the foreground.

PLATE 6.4

SPAWNING INDUCTION DISH

Aulacomya maoriana in individual spawning compartments. Some individuals have commenced spawning. 
PLATE 6-1

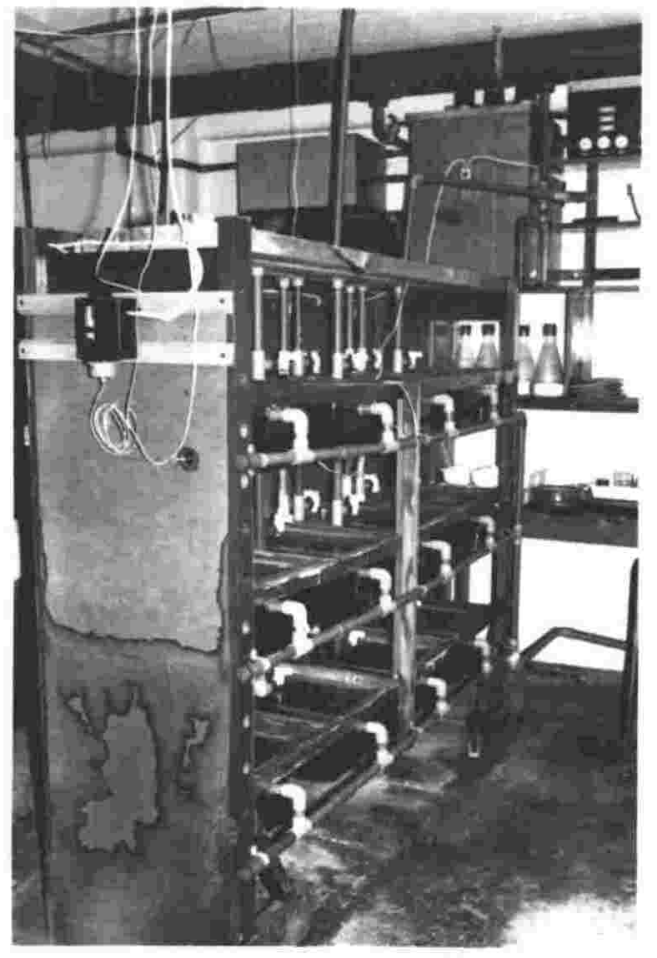

6- 2

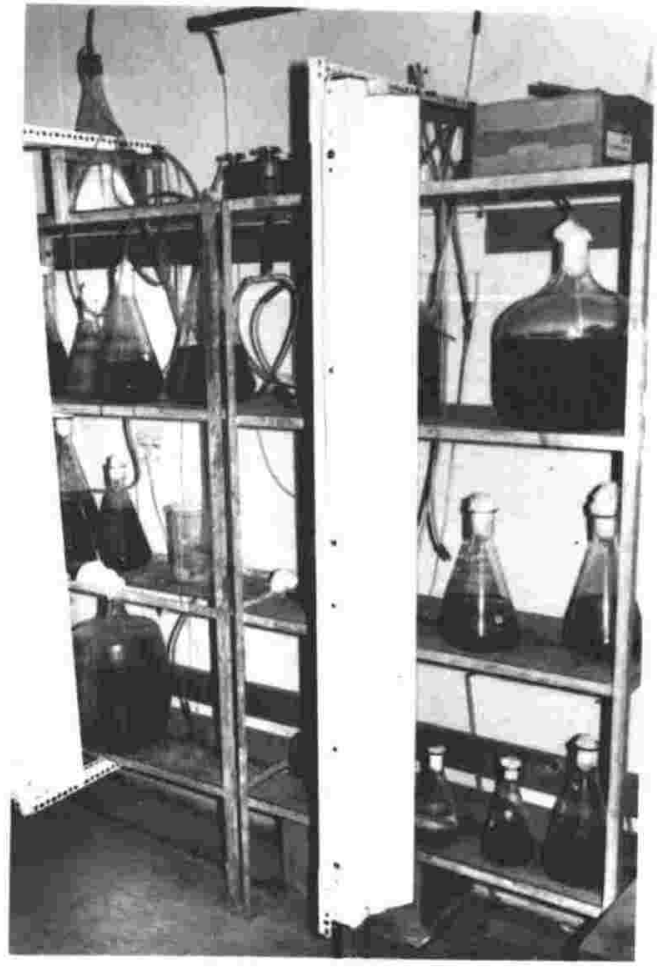

\section{6-3}
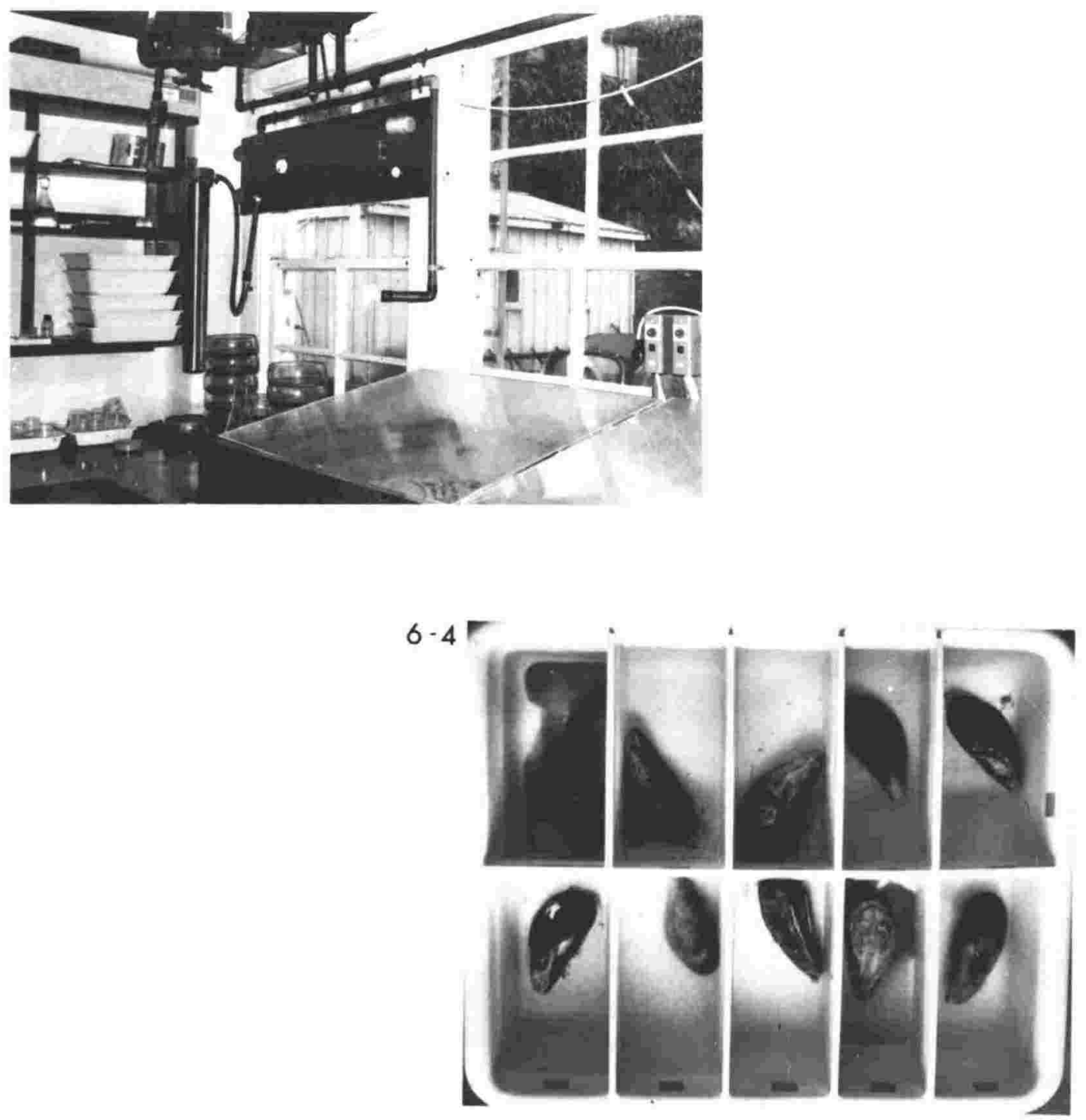
It was first passed through a Millipore cartridge filter (Type Millitube PF/MF) of $1.2 \mu \mathrm{m}$ pore size, and then sterilized by an ultra-violet unit as described by Loosanoff \& Davis (1963) and shown in Plate 6.3. Water was pumped through the system at a maximum rate of 80 litres/hour, depending on the age of the filter. The stainless steel filter housing showed early signs of corrosion but bacteriological tests (incubation of sample on agar) showed no signs of contamination.

Axenic cultures of Isochrysis galbana and Monochrysis lutheri were grown from innocula supplied by the Fisheries Research Division of the Ministry of Agriculture and Fisheries. Glass carboys of 15 litre capacity were used for the main cultures (Plate 6.2). Continuous illumination was supplied by Philips TL65W/34RS fluorescent tubes which also helped to maintain a temperature of around $19^{\circ} \mathrm{C}$. Compressed air filtered through a cellulose-acetate filter $(0.8 \mu \mathrm{m})$ was used for agitation. Provasoli (Provasoli et al, 1957), Oregon University (Malouf, 1970) and Erdschreiber (Walne, 1966) culture media were found to require considerable time to prepare. Vegemite Yeast Extract was an excellent substitute. After gentle warming and dilution with equal parts of distilled water, it was used at a rate of $2.0 \mathrm{ml}$ per litre of culture medium. A chemical analysis of Vegemite appears in Table 6.1.

Another type of algal culture, suitable only for adult 
TABLE 6.1 VEGEMITE APPROXIMATE ANALYSIS

$\begin{aligned} \text { Vegemite }= & \text { a concentrated autolysed extract made from Saccaromyces } \\ & \text { cerevisiae and other brewers' yeasts. }\end{aligned}$

Moisture

$36.0 \%$

Nitrogen

$4.5 \%$

Protein $(N \times 6.25)$

$28.6 \%$

Ash

$15.9 \%$

Carbohydrates

$9.9 \%$

Sodium chloride

$9.6 \%$

Phosphorus Pentoxide 2.4\%

Potassium monoxide $3.3 \%$

Magnesium oxide

$0.3 \%$

Calcium oxide

$0.3 \%$

Reducing sugars

$1.3 \%$

Approximate Vitamin Content (per g)

$\begin{array}{lr}\text { Thiamine } & 140 \mu \mathrm{g} \\ \text { Riboflavin } & 142 \mu \mathrm{g} \\ \text { Nicotinic acid } & 1000 \mu \mathrm{g} \\ \text { Pantothenic acid } & 50 \mu \mathrm{g} \\ \text { Folic acid } & 20 \mu \mathrm{g} \\ \text { Choline } & 5000 \mu \mathrm{g} \\ \text { Biotin .05-.07 } & 100 \mathrm{m \mu g} \\ \text { Inositol } 1.2 & 10 \mathrm{m \mu g} \\ \text { Pyrodokine } & 15-20 \mu \mathrm{g}\end{array}$

(as supplied by the manufacturers - Kraft Foods Limited Pty) 
shellfish, was grown in household baths on the roof of the laboratory by adding commercial fertilizer to seawater (Loosanoff \& Engle, 1942). There was no control over the organisms being cultured, the amount of light or the temperature, and the cultures were rather poor in winter.

\section{Conditioning}

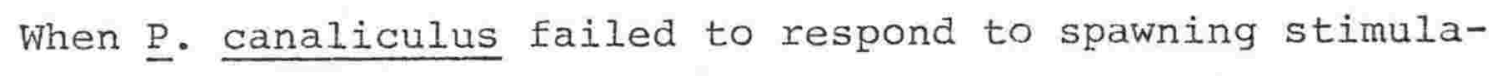
tion it was presumed they were not yet ready to spawn. A number of mussels were placed in the conditioning tanks and the temperature raised from $15^{\circ}$ to $22^{\circ} \mathrm{C}$ at the rate of $1^{\circ} /$ day. During this time they were fed regularly with the mixed algal culture. This method has been tried successfully by Loosanoff \& Davis (1950, 1952), Dannevig (1951), Davis \& Chanley (1956), Aboul-Ela (1960), Walne (1964), Malouf (1970) and others.

Since $\underline{M}$. edulis spawned on stimulation it was not necessary to condition them.

\section{Spawning Induction}

Mature adult mussels were thoroughly cleaned by scraping, rinsing in freshwater and drying, prior to being placed in individual trays in anticipation of spawning (see plate 6.4). The filtered and sterilized water in the trays was treated 
by the addition of $0.05 \mathrm{~g} / \mathrm{litre}$ Streptomycin sulphate and $0.03 \mathrm{~g} / 1$ itre Penicillin. Although the cleaning process was not intended as a stimulus for spawning, when applied to M. edulis and Aulacomya maoriana no further stimulation was necessary.

P. canaliculus failed to spawn after cleaning and required further stimulation. Ripe mussels were divided into groups of ten. A control group was left undisturbed while the rest were cleaned in the same manner as above and each group subjected to one of the following treatments:

1) Placed in treated water at ambient temperature

2) Placed in treated water at $24^{\circ} \mathrm{C}$ (Loosanoff \& Davis 1950)

3) Shaken vigorously in a bucket, then as in (2) (Field 1922, Young 1945).

4) Injected with $\mathrm{KCl}$ (Iwata 1951, Bayne 1965), $\mathrm{NH}_{4} \mathrm{OH}$ (Sagara 1958)

5) Pricking the adductor muscle (Loosanoff \& Davis 1950)

6) Tearing of adductor, then as in (1)

7) Wedging the valves open (Loosanoff \& Davis 1963)

8) Electric shock (Iwata 1950, Sugiura 1962)

9) Left dry for 8 hours, then as in (1)

10) Left under continuous bright light as in (1)

11) As in (1) with the addition of sperm suspension. 


\section{Culture Techniques}

Sperm suspension was added to a $500 \mathrm{ml}$ flask containing ova in sterile and antibiotic-treated water. After mixing and allowing the ova to settle back on the bottom of the flask, the water and excess spermatozoa were decanted off. Clean water was then added and the process repeated until most material in suspension was removed. The developing zygotes were then left undisturbed (apart from regular sampling) for 48 hours. Larval densities at this stage were c. 2000/ $\mathrm{ml}$.

After 48 hours, large particles in the culture were removed by a $120 \mu \mathrm{m}$ nylon monofilament sieve and the larvae collected on a $60 \mu \mathrm{m}$ sieve. After rinsing with sterile treated water they were returned to a clean flask to which an arbitrary amount of $\underline{I}$. galbana and $\underline{M}$. Iutheri was added. The flagellate densities were not determined.
6.3
RESULTS

Mytilus edulis aoteanus (Plates $6.5 \& 6.6$ )

There was no difficulty in obtaining gametes from $\underline{M}$. edulis, in fact they often spawned spontaneously in transfer to the laboratory. Keeping them out of water in a cool damp place and minimum handling usually prevented precipitous spawning. 
PLATE 6.5

MYTILUS EDULIS AOTEANUS - LARVAL DEVELOPMENT
a) Spermatozoa
b) Ovum with first polar body extruded (I hour)
c) First polar lobe (1 hour 30 minutes)
d) 2-cell stage ( 2 hours 30 minutes)
e) 8-cell stage (4 hours)
f) 4-cell stage (3 hours)

PLATE 6.6

MYTILUS EDUTIS AOTEANUS - LARVAL DEVELOPMENT (continued)
a) Blastula (6 hours)
b) Ciliated gastrula ( 8 hours)
c) Trochophore larva (20 hours)
d) Veliger larva - straight hinge (40 hours)
e) Veliger larva - early umbo (20 days)
f) Late veliger (90 days)

Scale on both Plates is $10 \mu \mathrm{m}$ unless stated otherwise. 
PLATE 6- 5
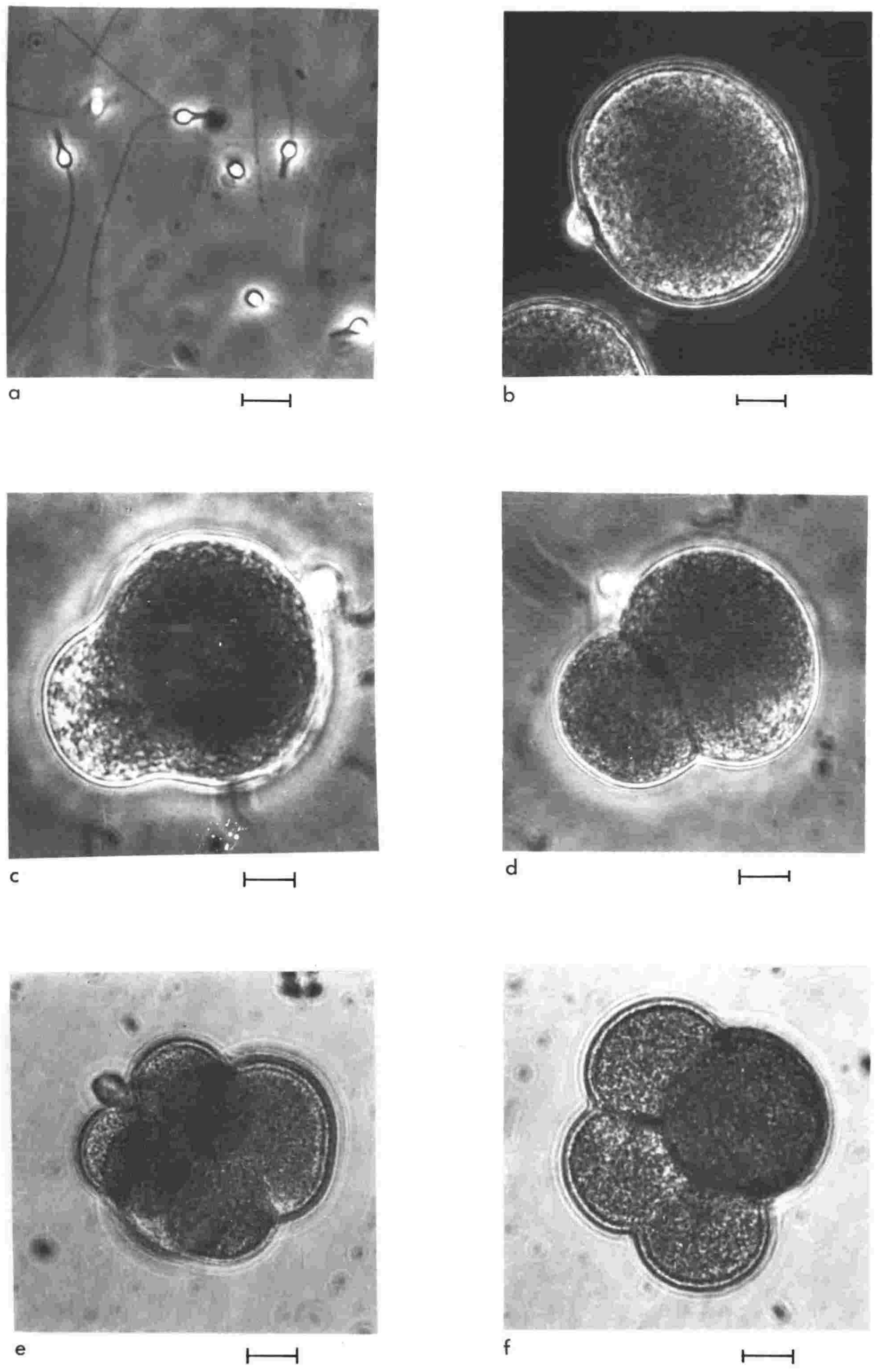
PLATE 6.6
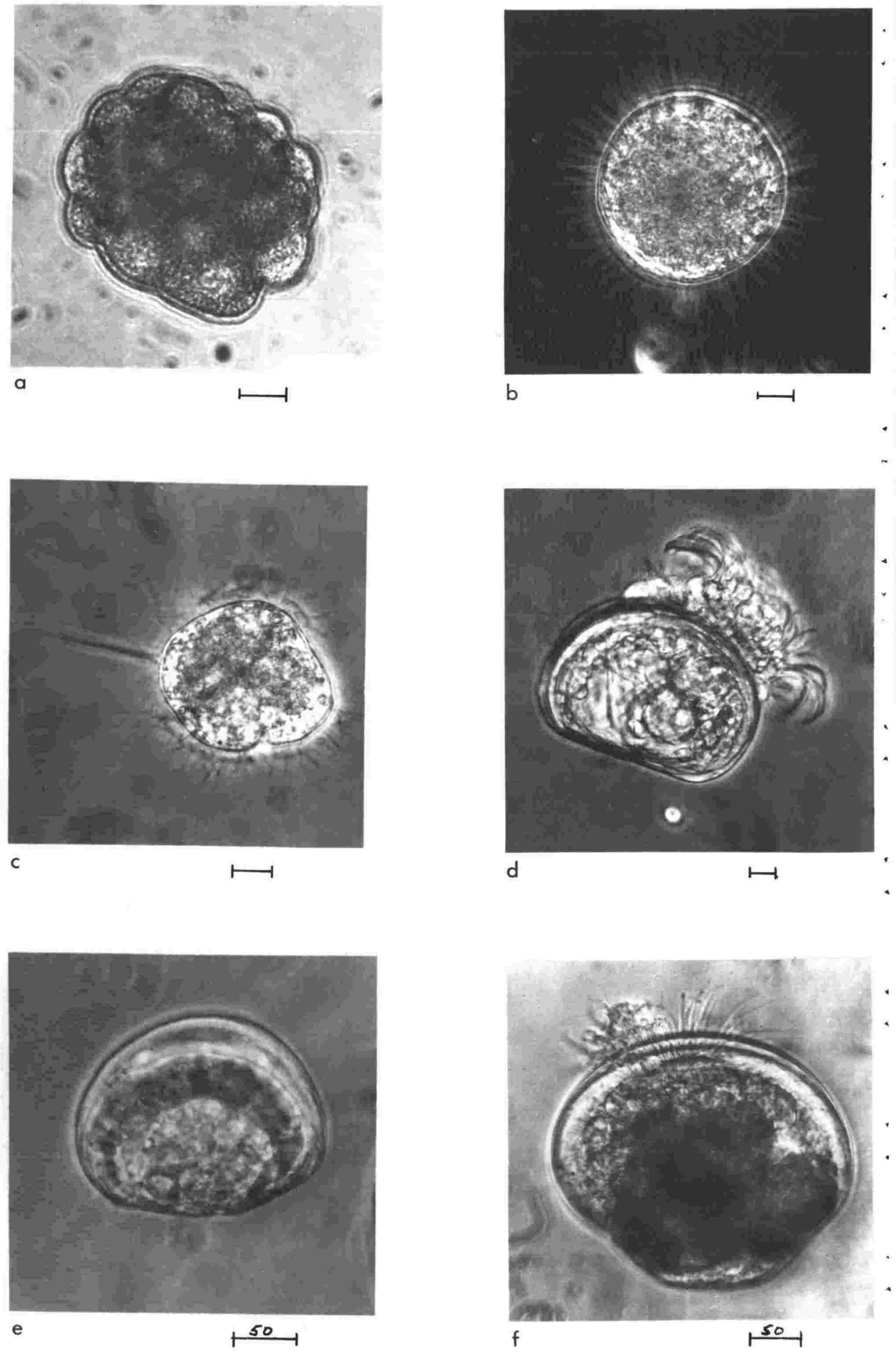
Mussels were cleaned of all adhering organisms and on being placed back in water spawning normally started within 20 minutes and $100 \%$ spawning was achieved by $4-5$ hours. Ova measured c. $65 \mu \mathrm{m}$ in diameter and were emitted in short orange rods, breaking up and settling quickly on the bottom. Spermatozoa were ejected in dense milky white clouds and remained in suspension. The total length of the sperm head (including acrosome) was c. $7 \mu \mathrm{m}$ and the tail was $65 \mu \mathrm{m}$. Spontaneous spawning normally took place during the night or early morning.

The first polar body was extruded after an hour and the polar lobe fully developed after 90 minutes. The extrusion of the second polar body was not observed. The 2-cell stage was reached by $2 \frac{1}{2}$ hours and after a further 30 minutes the embryo consisted of 4 cells $(3$ micromeres and a single large macromere). Ciliated gastrulae showing slight rotation were seen after 8 hours and the trochophore stage after 20 hours. The stomodaeum was noticed soon after and this was followed later by the appearance of the shell gland. The veliger stage was reached after 40 hours and the larvae now measured $120 \mu \mathrm{m}$ across the longest axis. The straight-hinge stage was passed after 20 days and at 30 days the umbo was distinct. At this stage the veliger larvae measured c. $280 \mu \mathrm{m}$. Eyespots appeared after 45 days and nylon monofilaments were provided as a settlement surface. After 90 days the larvae had still neither 
settled nor metamorphosed and the experiment was terminated.

Aulacomya maoriana (Plate 6.7)

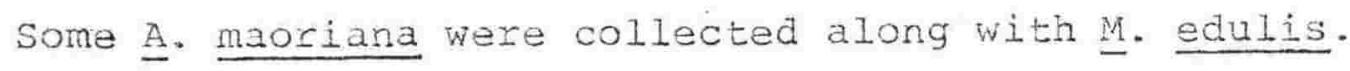
The mussels did not spawn after cleaning or after a rise in water temperature to $24^{\circ} \mathrm{C}$ and they were returned to running seawater at $16^{\circ} \mathrm{C}$. After 15 hours it was thought that some gametes had been released and after rinsing, the mussels were placed in spawning dishes where all spawned that evening.

The eggs were fertilised and after 13 hours most had reached the ciliated gastrula stage and were very mobile. An excess of sperm was still present in the culture and a number of morphologically abnormal larvae were present, due perhaps to polyspermy. All but the free-swimming larvae were discarded and the remainder reached the trochophore stage within 33 hours and the veliger stage within 60 hours. On the fourth day a dark glandular area was obvious in the central region of the animals (see Plate $6.7 e, f$, and $g)$. This was not seen in the larvae of $\underline{M}$. edulis although they had been fed on the same flagellates. After 8 days most of the larvae lost the straight-hinge but there was a great variation in size. The prodissoconch stage was reached on the 15 th day and by the 24 th day some individuals were up to $300 \mu \mathrm{m}$ in length. There was still 
AULACOMYA MAORIANA - LARVAL DEVELOPMENT
a) Spermatozoa
b) Ovum with first polar body extruded
c) Ciliated gastrula
d) Trocophore larva
e) Early veliger larva
h) Late veliger

f) g) Veligers

Scale represents $10 \mu \mathrm{m}$ unless stated otherwise 
PLATE 6.7
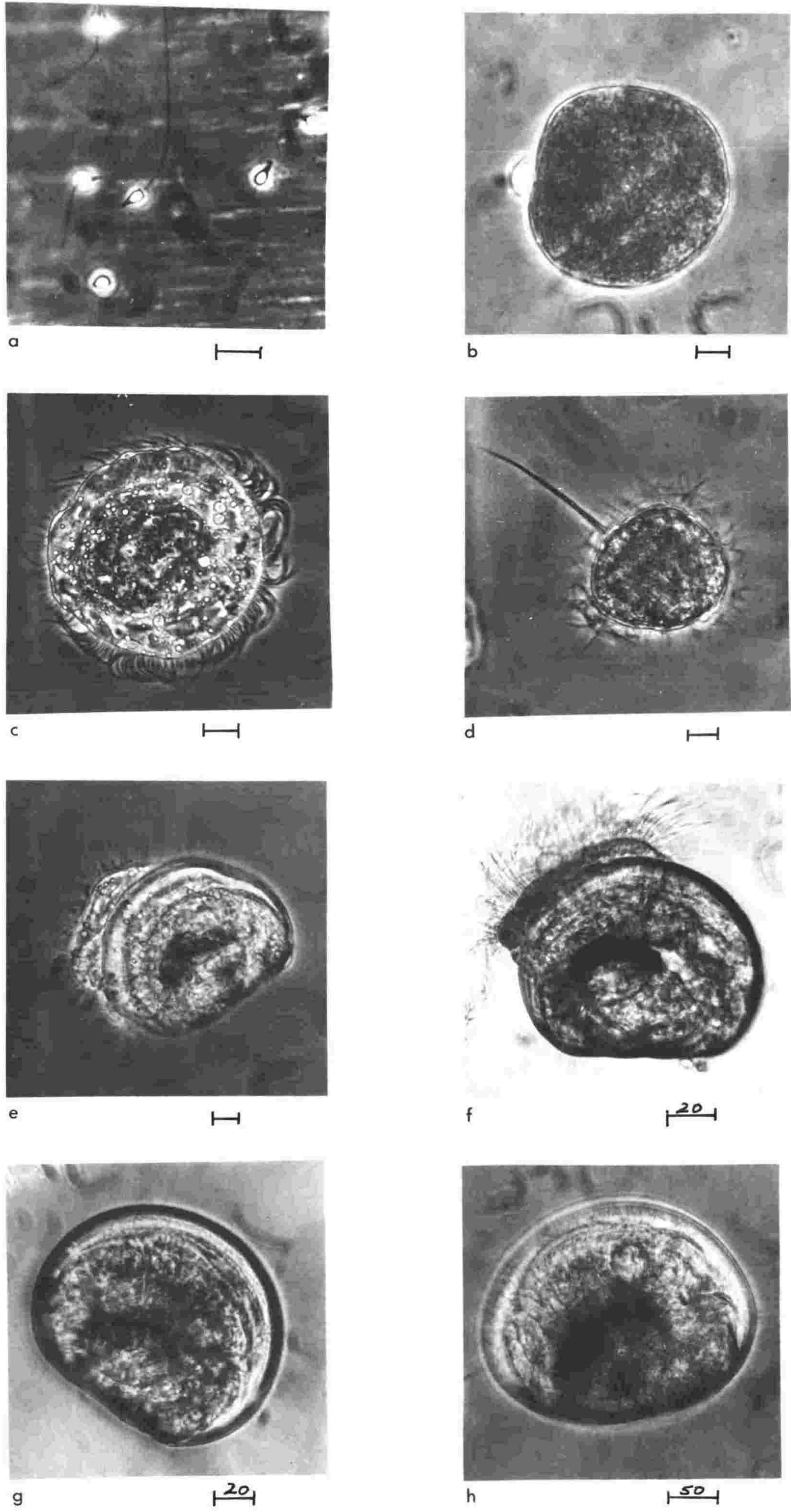
no sign of foot and the majority had succumbed to ciliate infection. The experiment was terminated after 30 days without settlement or metamorphosis taking place.

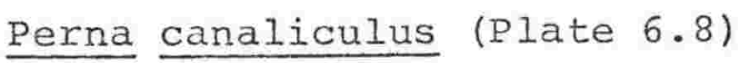

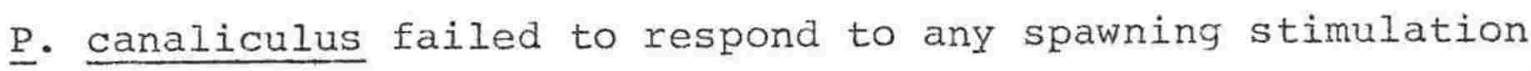
even after conditioning. The fact that spawning took place among the control group seems to indicate that among the stimulants used there must have been an inhibitor. Scraping the shell clean and placing in sterile treated water was carried out for all the induced groups and either or both of these procedures could have inhibited spawning.

Spontaneous spawnings took place in the laboratory but cultures raised from these or from control groups were contaminated and did not survive past the 8-cell stage. Ova were perfectly spherical and c. $68 \mu \mathrm{m}$ in diameter while spermatozoa had a total length of c. $55 \mu \mathrm{m}$ of which $5 \mu \mathrm{m}$ was the head. The 2 -cell stage was reached after 90 minutes and after $2 \frac{1}{2}$ hours some 8 -celled embryos were observed. Some embryos reached the ciliated gastrula stage after 12 hours but looked very abnormal. No flagellated trochophores were seen after 60 hours and the culture was discarded. 


\section{PERNA CANALICULUS - LARVAL DEVELOPMENT}
a) Spermatozoa
b) Ovum
c) 2-cell stage
d) 4-cell stage
e) 8-cell stage

Scale represents $10 \mu \mathrm{m}$ 


\section{PLATE $\quad 6-8$}

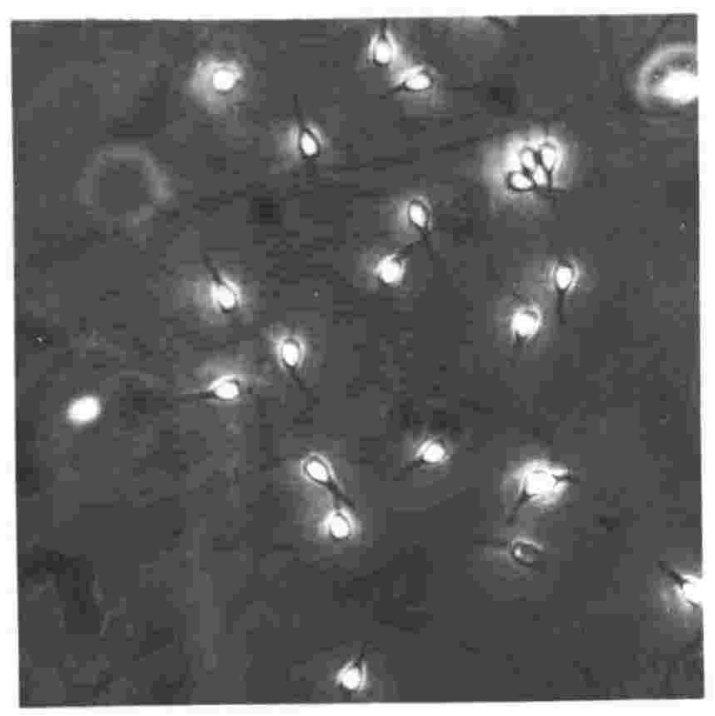

a

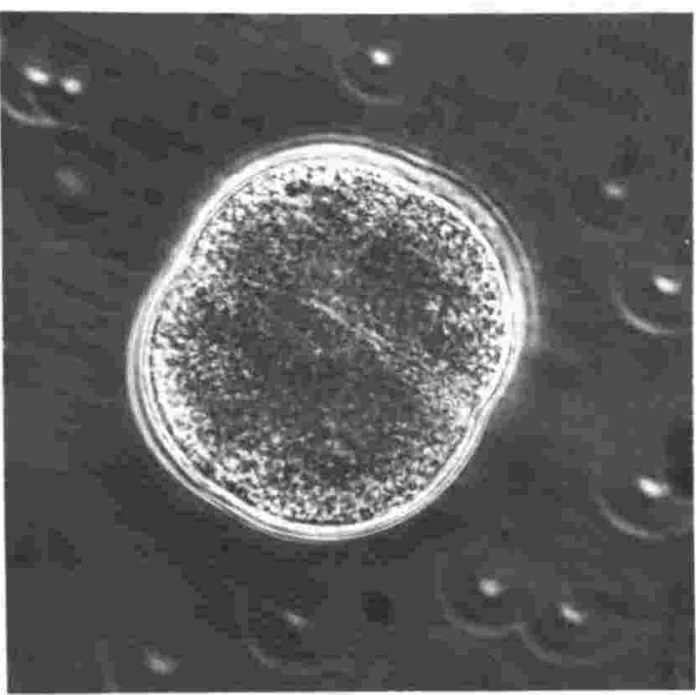

c

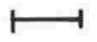

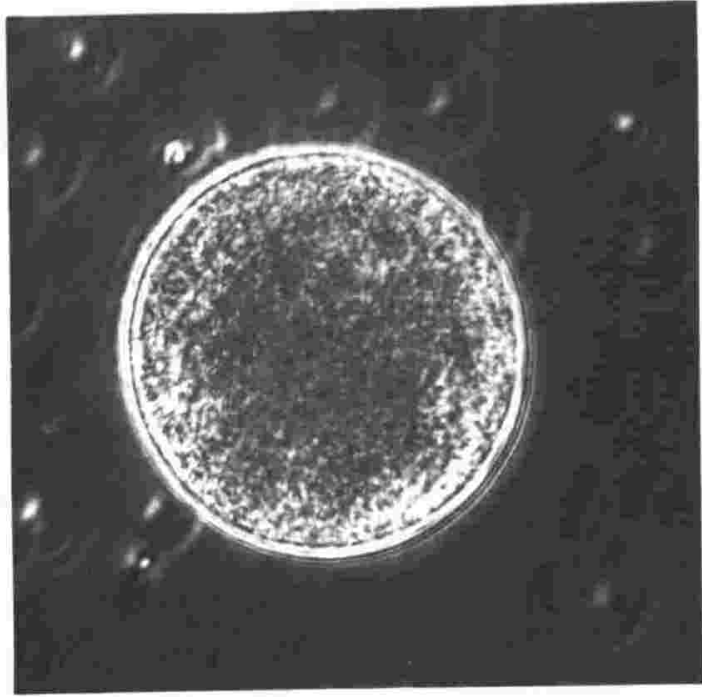

b
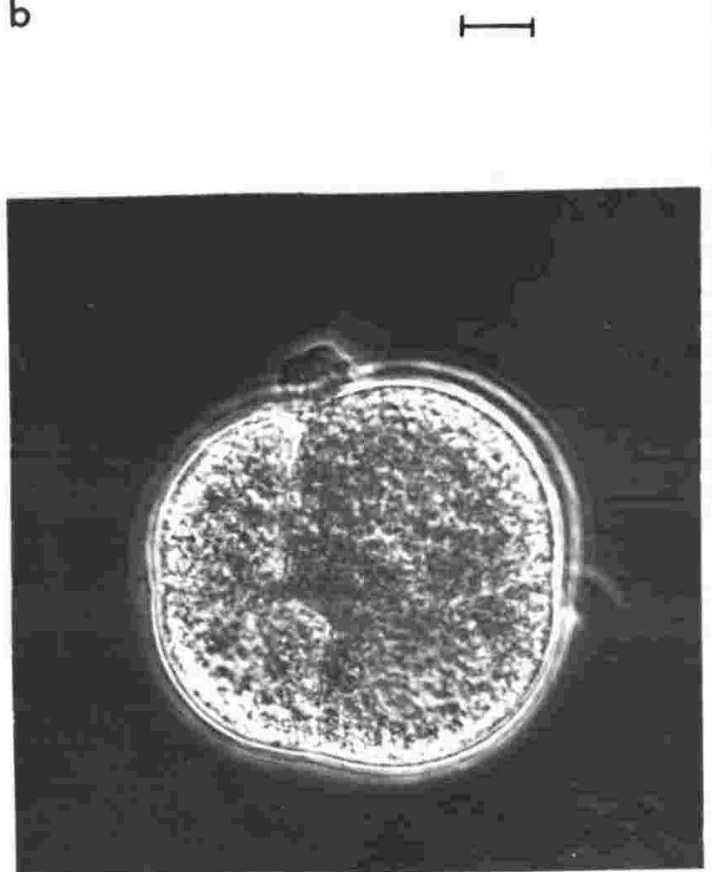

d

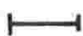

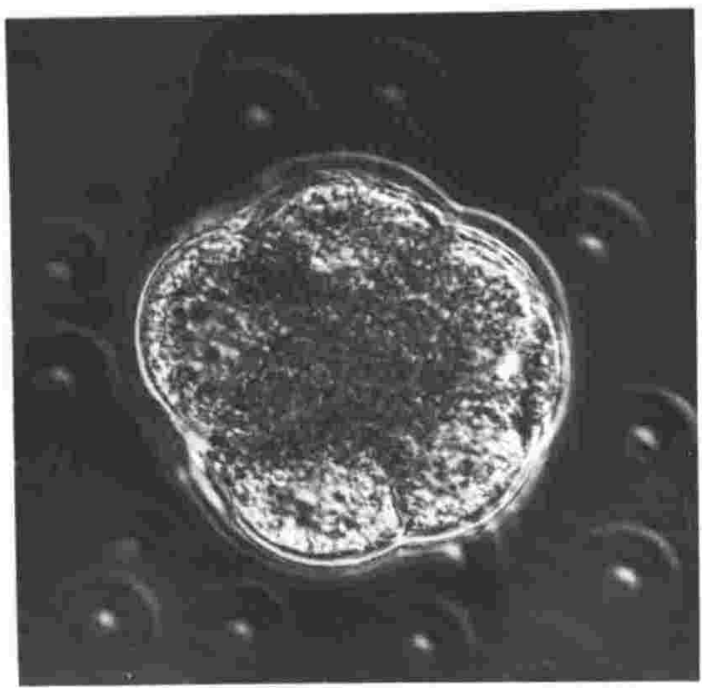


"Rearing larvae is often the most difficult part of marine cultivation" (Mason, 1972). Experimental conditions which are apparently identical often produce different results (Walne, 1956). Failure to rear bivalve larvae in the laboratory could be due to poor handling facilities for eggs and larvae, lack of proper food, mortality caused by parasites and pathogens (Loosanoff \& Davis, 1963), and lack of a suitable settlement substrate (Bayne, 1965).

All gametes used in these experiments were shed normally by the parents since it is known that stripped gametes often lead to abnormal embryos (Loosanoff \& Davis, 1963, Walne, 1964a). Although no control was exercised over the quality of water (apart from sterilization and treatment with antibiotics) or the ambient environment, this should not have hindered larval development. Oxygen content and inorganic ions of the water as well as light intensity seem to have no effect on delay of metamorphosis (Bayne, 1965). Cultures were kept at room temperature (c. $20^{\circ} \mathrm{C}$ with a drop of up to $5^{\circ} \mathrm{C}$ at night) (c.f. Loosanoff \& Davis, 1963). The method used for changing the water and washing the larvae seemed less traumatic than that of Loosanoff \& Davis (1963). Cultures were normally started at densities of c. 2000 ova/ ml. Davis (1953) and Loosanoff \& Davis (1963) have shown that at densities above $1000 / \mathrm{ml}$ development can be impeded. 
While in the present study up to $50 \%$ of embryos were discarded at the first water change, the larval density could still have been too high.

White (1937) reared $\underline{M}$. edulis larvae on Nitzchia and Loosanoff et al (1955) say that they will "thrive on most micro-organisms provided they are small enough to be ingested." Isochrysis galbana and Monochrysis lutheri were used in the present experiments. These two algae are not only small enough, but they also have no cell wall and produce little, if any, toxic external metabolites (Davis 1953, Davis \& Guillard 1958, Walne 1970). However, an excess of algal food could well hinder development and no check was kept during the present experiments.

As a rule gametes were obtained from parents that had been cleaned and placed in sterile water treated with antibiotics before spawning commenced. Embryos in these cultures appeared healthy and active and no parasites or pathogens were noticed in the cultures. Whenever gametes were taken from holding tanks without the parents having been prepared, contamination with ciliates was evident and often the embryos were abnormal and soon died. By preparing the parents and avoiding gametes spawned under uncontrolled conditions it was possible to eliminate all parasites and pathogens.

Loosanoff et al (1951) and Loosanoff (1959) provided no 
special substrate for the larvae and succeeded in obtaining settlement on the glass walls of the culture vessel. However, Bayne (1965) found that larvae become capable of attachment a considerable time before they will attach on glass and that the majority die before doing so. He also found that filamentous algae were a successful substrate while nylon filaments were extremely unsuitable. Since mussel larvae settled well on polypropylene filaments in the field during the present experiments, the same material was offered to the larvae in the laboratory but without success. Synthetic filaments in the field have a chance of being 'conditioned' by epiphytes while the laboratory filaments were sterilized before use! This could well be the reason for their failure to attract any larvae.

In conclusion it can be said that the present experiment was partially successful in rearing the larvae of $\underline{M}$.

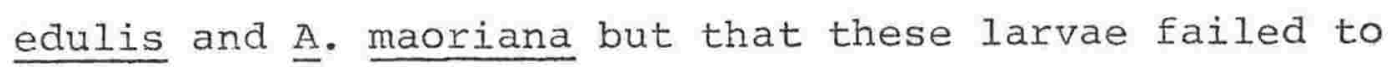
metamorphose. The most likely causes of failure were a high larval density, an excess of food organisms and the lack of a suitable settlement substrate. 
I would like to express my gratitude to Mr George Grainger, resident technician at the Marine Laboratory, who assembled the larval rearing unit and maintained it in working order. Thanks are also due to Messrs A.C. Healing of Wellington for making available one of the Vitreosil Heaters used in heating the seawater. 
ABOUL-EIA, I.A. (1960) Conditioning Ostrea edulia from the Limfjord for reproduction out of season. Meda. Komm. Havundersog Kbh. (Ny. Ser.) $2(25)$

BAYNE, B.L. (1965) Growth and delay of metamorphosis of the larvae of Mytilus edulis L. Ophelia 2(I): 1-47 CULIINEY, J.L. (1971) Laboratory rearing of the larvae of the mahogany date mussel Lithophaga bisulcata. Bulletin of Marine Science $21(2): 591-602$

DANNEVIG, A. (1951) Lobster and Oyster in Norway. Proceedings Conseil Permanent Exploration de la mer $128(2): 92-6$

DAVIS, H.C. (1953) On food and feeding of larvae of the American oyster $\underline{C}$. virginica.

Biological Bulletin $104(3): 334-350$

DAVIS, H.C. \& CHANLEY, P.E. (1955) Spawning and egg production of oysters and clams. Proceedings of the National Shellfisheries Association. $46: 40-51$

DAVIS, H.C. \& GUILLARD, R.R. (1958) Relative value of ten genera of micro-organisms as food for oyster and clam larvae. U.S. Fish and Wildlife Service, Fisheries Bulletin 58(136): 293-304 
DAVIS, H.C. \& LOOSANOFF, V.I. (1953) Utilization of

different food organisms by clam larvae.

Anatomical Records 117: 646

FIELD, I.A. (1922) Biology and economic value of the sea mussel Mytilus edulis. Bulletin of the U.S. Bureau of Fisheries 38: 127-259

GUILLARD, R.R. (1957) Some factors in the use of nanoplankton cultures as food for larval and juvenile bivalves. Proceedings National Shellfisheries Association 48: 134-42

HIDU, H. \& UKELES, R. (1962) Dried unicellular algae as food for the larvae of the hard clam Mercenaria mercenaria. Proceedings National Shellfisheries Association 53: 85-102

IWATA, K.S. (1950) Spawning of Mytilus edulis (2) Discharge by electrical stimulation. Nihon Suisan Gakkai Shi Tokyo 15: 443-6

IWATA, K.S. (1951) Spawning of Mytilus edulis (4) Discharge by $\mathrm{KCl}$ injection. Bulletin Japanese Society for Scientific Fisheries $16(1): 393-4$

JORGENSEN, C.B. (1966) The Biology of Suspension Feeders Pergamon Press, London. $357 \mathrm{pp}$.

LOOSANOFF, V.I. (1945) Precocious gonad development in oysters induced in mid-winter by high temperatures. Science $102(2640): 124-5$ 
LOOSANOFF, V.I. (1971) Development of shellfish culture techniques. Proceedings Conference on Artificial Propagation of Commercially Valuable Shellfish, October 1969, University of Delaware. 9-40

LOOSANOFF, V.L. \& DAVIS, H.C. (1950) Conditioning

V. mercenaria for spawning in midwinter and breeding its larvae in the laboratory. Biological Bulletin $98: 60-65$

LOOSANOFF, V.I. \& DAVIS, H.C. (1952) Temperature requirements for maturation of gonads of northern oysters. Biological Bulletin 103: 80-96

LOOSANOFF, V.L. \& DAVIS, H.C. (1963) Rearing of Bivalve Molluscs, in Advances in Marine Biology 1:1-136

LOOSANOFE, V.L. \& ENGLE, J.B. (1942) Use of complete fertilizer in cultivation of micro-organisms. Science 95: 487-88

LOOSANOFF, V.L. et al (1955) Food requirements of some bivalve larvae. Proceedings National Shellfisheries Association 45: 66-83

LOOSANOFF, V.L. et al (1966) Dimensions and shapes of larvae of some marine bivalve mollusks. Malcologia $4(2): 351-435$

LUNETTA, J.E. (1969) Fisiologia da reproducao do mexilhoes (Mytilus perna L. mollusca lamellibranchia) Zoologia e Biologia Marinha 26: 33-111 
MALOUF, R. (1970) Oregon State University Pilot Oyster Hatchery. Oregon State University. $9 \mathrm{pp}$.

MASON, J. (1972) Mollusc culture in Scotland. World Fishing September 1972 42-44

PROVASOLI, L. et al (1957) The development of artificial media for marine algae. Archives fur Mikrobiologie $25: 392-428$

SAGARA, J. (1958) Artificial discharge of reproductive elements of certain bivalves caused by treatment of seawater and by injection with $\mathrm{NH}_{4} \mathrm{OH}$.

Bulletin Japanese Society for Scientific Fisheries $23(9): 505-10$

SUGIURA, Y. (1962) Electrical induction of spawning in two marine invertebrates (Urechis unicinctus, hermaphroditic Mytilus edulis) Biological Bulletin $123(1): 203-06$

WALNE, P.R. (1956) Experimental rearing of the larvae of Ostrea edulis in the laboratory. Fisheries Investigations Series II 20(9): 1-23

WALNE, P.R. (1964) A seawater supply system in a shellfish culture laboratory, in Seawater Systems for Experimental Aquariums. U.S. Department of the Interior, Research Report 63 of Fish and Wildlife Service. 155-59 
WALNE, P.R. (1964a) The culture of marine bivalve larvae, in Wilbur \& Yonge edit. Physiology of the Mollusca 197-210

WALNE, P.R. (1966) Experiments in the large-scale culture of the larvae of Ostrea edulis L. Fisheries Investigations Series II 25 (4) 53 pp.

WALNE, P.R. (1970) Studies on the food value of nineteen genera of algae to juvenile bivalves of the genera Ostrea, Crassostrea, Mercenaria and Mytilus. Fisheries Investigations Series II 26 (5) $62 \mathrm{pp}$.

WISELY, B. (1964) Aspects of reproduction, settling and growth in the mussel Mytilus edulis planulatus Lamarck. Journal Malacological Society of Australia 8: 25-30

YOUNG, R.T. (1945) Stimulation of spawning in the mussel (M. Californianus) Ecology $26(1): 58-69$ 